DOE/NASA CONTRACTOR REPORT
DOE/NASA CR- 150860

December 1978

\title{
QUALIFICATION TEST AND ANALYSIS REPORT-- SOLAR COLLECTORS
}

Prepared from documents furnished by

Owens-Illinois, Inc.

Solar Energy Products Group

Toledo, Ohio 43666

Under Contract NAS8-32259 with

National Aeronautics and Space Administration

George C. Marshall Space Flight Center, Alabama 35812

For the U. S. Department of Energy

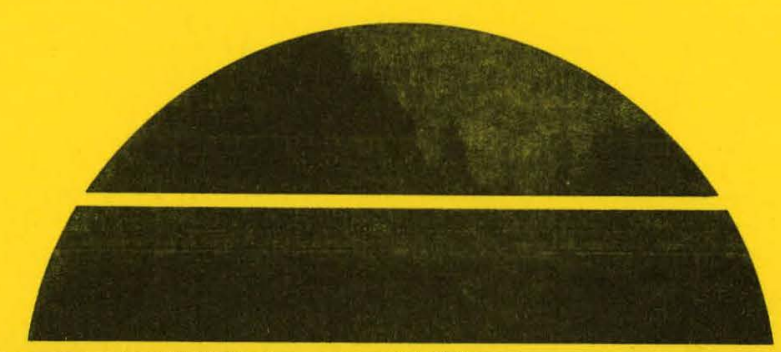

\section{U.S. Department of Energy}




\section{DISCLAIMER}

This report was prepared as an account of work sponsored by an agency of the United States Government. Neither the United States Government nor any agency Thereof, nor any of their employees, makes any warranty, express or implied, or assumes any legal liability or responsibility for the accuracy, completeness, or usefulness of any information, apparatus, product, or process disclosed, or represents that its use would not infringe privately owned rights. Reference herein to any specific commercial product, process, or service by trade name, trademark, manufacturer, or otherwise does not necessarily constitute or imply its endorsement, recommendation, or favoring by the United States Government or any agency thereof. The views and opinions of authors expressed herein do not necessarily state or reflect those of the United States Government or any agency thereof. 


\section{DISCLAIMER}

Portions of this document may be illegible in electronic image products. Images are produced from the best available original document. 
NOTICE

This report was prepared to document work sponsored by the Untted States Government. Nelther the United States nor its agents the United States Department of Energy, the United States National Aeronautics and Space Adminlatration, nor any federsl employees, nor any of thefi contractors, sutcortractors or their employees, make any warranty, express or implite, or assume any legal 1lability or responstbility for the accliacy, completenes, or usefulness of any informat1on, apparatus, product or process disclosed, or represent that 1ts use would not infringe privately owned rights. 


\begin{tabular}{|c|c|c|}
\hline $\begin{array}{l}\text { 1. REPORT NO. } \\
\text { DOE/NASA CR-150860 }\end{array}$ & 2. GOVERNMENT ACCESSION NO. & 3. RECIPIENT'S CATALOG NO. \\
\hline \multirow{2}{*}{\multicolumn{2}{|c|}{$\begin{array}{l}\text { 4. TITLE AND SUBTITLE } \\
\text { Qualification Test and Analysis Report-- } \\
\text { Solar Collectors }\end{array}$}} & $\begin{array}{l}\text { 5. REPORT DATE } \\
\text { December } 1978\end{array}$ \\
\hline & & 6. PERFORMING ORGANIZATION CGIDE \\
\hline \multicolumn{2}{|l|}{ 7. AUTHOR(S) } & 8. PERFORMING ORGANIZATION REPORT \# \\
\hline \multirow{3}{*}{\multicolumn{2}{|c|}{$\begin{array}{l}\text { 9. PERFORMING ORGANIZATION NAME AND ADDRESS } \\
\text { Owens-Illinois, Inc. } \\
\text { Solar Energy Products Group } \\
\text { Toledo, Ohio } 43666\end{array}$}} & 10. WORK UNIT, NO. \\
\hline & & \begin{tabular}{|l}
11. \\
CONTRACT OR GRANT NO. \\
NAS $8-32259$
\end{tabular} \\
\hline & & \multirow{2}{*}{$\begin{array}{l}\text { 13: TYPE OF REPOR } T \text { \& PERIOD COVERED } \\
\text { Contractor Report }\end{array}$} \\
\hline \multicolumn{2}{|c|}{ 12. SPONSORING AGENCY NAME ANO ADORESS } & \\
\hline \multicolumn{2}{|c|}{ National Aeronautics and Space Administration } & 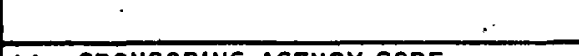 \\
\hline Washington, D. C. 205 & & 14. SPONSORING AGENCY CODE \\
\hline
\end{tabular}

15. SUPPLEMENTARY NOTES

This work was done under the technical management of Mr. John Caudle, George C. Marshall Space Flight Center, Alabama.

16. ABSTRACT

Test results show that the Owens-nlinois Sunpak ${ }^{\text {TM }}$ Model SEC 601 air-cooled collector meets the national standards and codes as defined in the Subsystem Performance Specification and Verification Plan of NASA/MSFC Contract NAS8-32259, dated October 28, 1976. The architectural and engineering firm of Smith, Hinchman and Grylls, Detroit, Michigan, acted in the capacity of the independent certification agency.

The program calls for the development, fabrication, qualification and delivery of an air-liquid solar collector for solar heating, combined heating and cooling, and/or hot water systems: 
THIS PAGE

\section{WAS INTENTIONALLY LEFT BLANK}




\section{TABLE OF CONTENTS}

Certification Test Report. 1

Half Hour Data Summaries 6

Collector Efficiency $\quad 12$

$\begin{array}{ll}\text { Standardization of Eppley Pyranometer } & 21\end{array}$

System Design Conditions $\quad 34$

$\begin{array}{ll}\text { Hail Impacts Test } & 73\end{array}$

Fail Safe Controls $\quad 84$

Thermal Shock Testing 90

$\begin{array}{ll}\text { Effects of External Environment } & 106\end{array}$

This report wotice

sponsored by the prepared as an account of work

United States United States Government. Neither the

Energy, nor any of United States Department of

contractors, subcont their employeas, nor any of Uheir

any warm, subcontractors, of their employees, makes

liability or is expiess ur implied, or ascumes any leyil

or usefutess of any inf for the accuracy, completeress

proces diss of any information, apparatus, product or

proces disclosed, or represents that its use would or

infringo privatsly uwits the use would not 


\section{Certification Test Report}

The Owens-Illinois, Inc., SUNPAK ${ }^{T M}$ Model SEC 601 air cooled collector $s$ has been certified it meets national standards and codes as defined by the Subsystem Performance Specification and Verification Plan of contract NAS8-32259. The design, fabrication, installation and verffication test and analysis of the Mode1 SEC-601 collector were accomplished under contract NAS8-32259, dated October 28, 1976. The Architectural and Engineering firm , Smith, Hinchman and Grylis, Detroit, Michigan, acted in the capacity of the independent certification agency.

The SUNPAK ${ }^{T M}$ Model SEC-601 collector was tested and evaluated to the applicable sections of the Interim Performance Criteria for Solar Heating and Combined Heating and Cooling Systems and Dwellings prepared for the U. S. Department of Housing and Urban Development by the National Bureau of Standards, dated January 1, 1975. The Model SEC-601 collector successfully completed all requirements and criterion of the Verffication Test Program as evidenced by the documentation which follows.

The SUNPAK ${ }^{T M}$ Model SEC-601 air cooled collector is a marketable subsystem for solar heating and combined heating and cooling systems for dwellings and commercial installation.

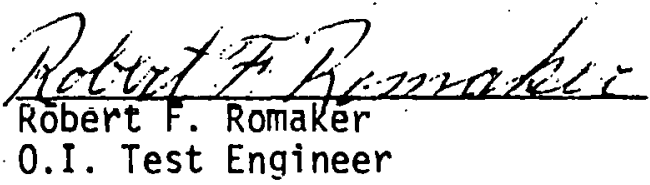

O.I. Test Engineer

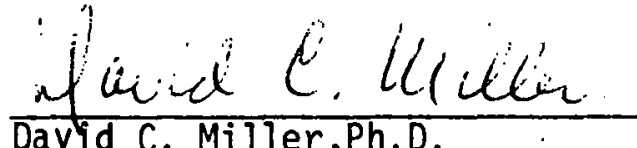

SH\&G Certification Ofricer

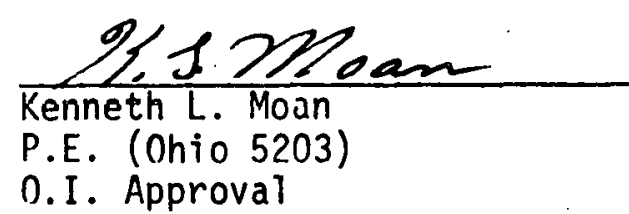

P.E. Approval

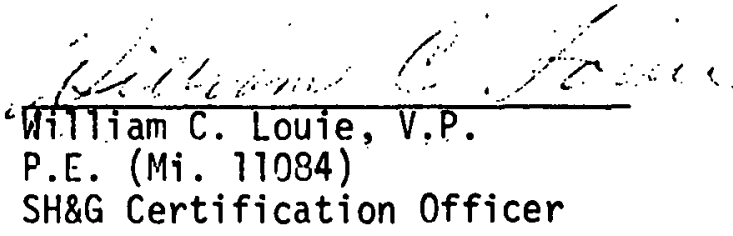




\subsection{Collector Ferfornance.}

1.3.1 Collector efficiency.

The thermal performance of the Model SEC-601 air cooled collector was investigated on the basis of its operating performance on an all day basis. That is, the useful energy gain of the collector:

$$
q_{u}=\dot{m c}\left(T_{0}-T_{i}\right)
$$

was evaluated in five (5) minute increments from sunrise to sunset. Test points were obtained for relatively clear day operating conditions for $\left(\overline{\mathrm{T}} \mathrm{i}-\overline{\mathrm{T}}_{\mathrm{a}}\right) / \overline{\mathrm{I}}_{\mathrm{TP}}$ near $0.04,0.05,0.3,0.44,0.48,0.60$. Additional test points were also obtained under cloudy and internittent cloudy day conditions. Solar radiation was measured in the plane of the collector using an Eppley PSP with integrator for the total radiation measurement and an Eppley 8-48 with shadow band and integrater for the diffuse solar radiation measuremeril.

The five minute incremental data were summed over the day from sunrise to sunset. The apprnximate collector fluid inlet teriperature for a given test day was cstablished during the night time hours prior to the test day. The ncar zero intercept test puint data was obtained by ingesting ambient air into the air fan inlet and duniping the effluent from the collector overboard to anbient. The collector inlet teimperature thus fluctuated throughout the day wit.h ambient temperature. The higher collector fluid inlet temperatures were obtained by using a liquid energy source and an air liquid heat exchanger to establish 
the collector air inlet temperature. Near constant inlet temperatures were obtained by using city water to dilute the liquid energy source and dumping the excess water to the sewer.

Figures 1.3.1(a) through (f) contain the computer output data for the six specific days used to establish the Model SEC 601 air cooled collector characteristic efficiency curve. The curve is presented in Figure 1.3.1 $(g)$. The data points are noted by open circles. Added experimental data points are indicated in Figure 1.3.1(g) by the " $X$ " symbol. The computer output data has been summed in half hour increments to reduce the volume of data resulting from 5 minute increment evaluation. Note that the time column is solar time for each day of test. The test loop schematic is indicated in Figure 1.3.1(h). The Model SEC-601 air cooled collector was mounted on a south facing roof sloped at $45^{\circ}$. The roof was faced with Alcoa Bone thite \#K2028-30 (fluarocarbon) diffuse radiation material. The as received total reflectance which approximates the value of diffuse reflectance was $78.57 \%$. See Figure $1.3 .1(i)$ for the receiving test report.

The collector temperalure risc was measured with a 4 element thermopile constructed from Type $T$ copper constant wire. The thermocouples were calibrated by the Instrument Services Standards Lab of 0.I. The calibration data is attached as Figure 1.3.1(j) [3 sheets]. The thermopiles were constructed using couples 1 through 8.

The experimental data is captured on magnetic tape using a Fluke Data Logger, Model 2240A, John Fluke Company, Mt. Lake Terrace, Washington, 98043. The Fluke is calibrated in approximately 6 month intervals. 
See Figure 1.3.1 (k) [3 sheets] for the calibration data.

Radiation data is obtained using Eppley Pyronometers mounted in the tilt plane of the collector. A PSP pyronometer is used to measure total radiation and an 8-48 pyronometer with shadow band is used to measure diffuse radiation. The radiation levels are integrated over the 5 minute interval between data points. The calibration data for the pyronometers are attached as Figurc 1.3 .1 (1) for total and Figure 1.3.1 (m) for the diffuse measurements.

The air mass flow is measured using a Model Fan-E unit manufactured by the Air Monitor Corporation, Santa Rose, CA. Descriptive literature is attached as Figure 1.3.1 $(n)$. The circular - 6 inch diameter model is used. The Special FAN-E unit was purchased. It was mounted in accordance with the manufacturer's instructions as contained in Figure 1.3.1(0).

The analytical model for collector efficiency based on the experimental teșt data is:

$\bar{\eta} \cdot \sum\left[\dot{m} C p\left(T_{0}-T i\right)\right] / \Sigma I_{T P} \times A_{C}$

The emperical relationship for the Nodel SEC-601 collector 1s:

$\pi=.58-.14(\mathrm{Tin}-\mathrm{Ta}) / \mathrm{I}_{\mathrm{TP}}$

The thermal performance curve of the Model SEC-601 air cooled collector is indicated as the dashed line in Figure 1.3.1(g). The solid line indicates the thermal performance as required by Appendix $H$ of the contract. The dash-dot line indicates the thermal performance developed for the 144 tube ERDA collector array over a long period of time. 
c

- Review of items 1.3 and 1.3 .1 successfully completed.
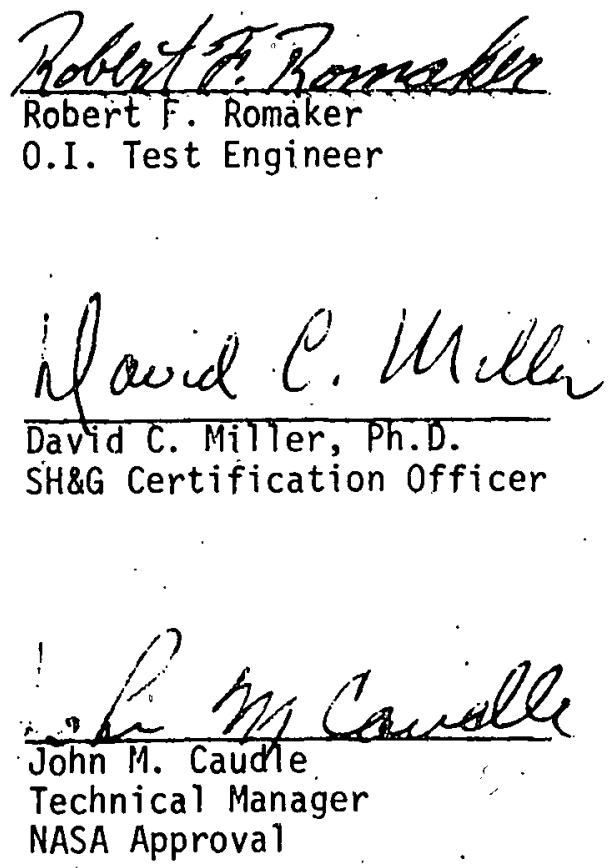

Tensuchs. Moan

Kenneth L. Moan

P.E. (Ohio 5203)

0.I. Approval

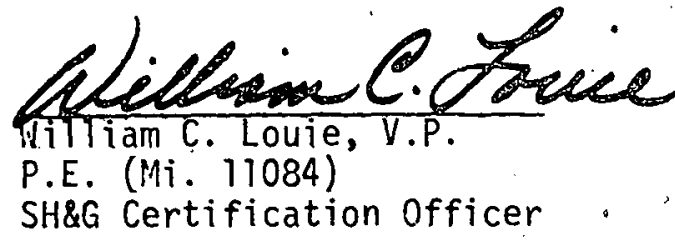


HALF-HOURLY DATA SUMMARY FOR 5-2Z-78 DAY NO. 142

\begin{tabular}{|c|c|c|c|c|c|c|c|c|c|c|}
\hline $\begin{array}{l}\text { OL AR } \\
\text { TIME }\end{array}$ & ITP & IDP & RD & $\begin{array}{l}\text { ATR } \\
\text { FLOM }\end{array}$ & $\begin{array}{r}\text { INLET } \\
\text { TEMP }\end{array}$ & $\begin{array}{l}\text { AMB } \\
\text { TEMP }\end{array}$ & $\begin{array}{l}\text { OUT } \\
\text { TEMP }\end{array}$ & Qu & EFF & $\mathrm{DT} / \mathrm{I}$ \\
\hline 15 & 0 . & 0 . & 0.0 & HOZ. & मृ. & 52. & 62. & -133. & 0.00 & 0.00 \\
\hline 45 & 0 . & 0 . & 0.0 & 847 . & hं. & $51:$ & 61. & -1 . & 0.00 & 0.00 \\
\hline 115 & n. & 0 . & 0.0 & $a+1$. & (1) & $+i 1$. & hl. & -134. & 0.00 & 0.00 \\
\hline 145 & 0. & 0. & 0.0 & 443. & 61. & 50. & 50. & -140. & $0.01)$ & $0.0 n$ \\
\hline 215 & 0 . & 0 . & 0.0 & सUप. & (i). & 50. & no. & - I५?. & 0.00 & 0.00 \\
\hline 245 & $n$. & 0. & 0.0 & Rपंड. & sic. & 50. & 60. & $-14 h$. & 0.00 & 0.00 \\
\hline 315 & 0. & 0. & 0.0 & BOA. & no. & 49. & 59. & -117. & 0.00 & 0.00 \\
\hline 345 & 0. & 0. & 0.0 & 89R. & 59. & 4H. & 54. & -143 & 0.00 & 0.00 \\
\hline 415 & $n$. & 0. & 0.0 & ค99. & 59. & 49. & 58. & -144 & 0.00 & 0.00 \\
\hline 445 & 1. & 0 . & 0.3 & 400. & $5 x$. & 4B. & 58. & -110. & -1.45 & 12.08 \\
\hline 515 & 6 & 5 & 0.9 & 899. & $5 H$. & 47. & 59. & 74 & 0.14 & $1 . \mathrm{HZ}$ \\
\hline 545 & 1.3. & 11. & 0.8 & $9 n 4$. & $58:$ & 47. & 59. & $2 \times 7$. & 0.25 & 0.85 \\
\hline 615 & 31 & c0. & 0.6 & 900. & 59. & 50. & 62. & 642 & 0.25 & 0.31 \\
\hline 645 & 57. & 27. & 0.5 & 895. & 60. & 52. & h8. & •לי 175 & 0.37 & 0.14 \\
\hline 715 & 77 & 32. & 0.4 & 890. & hl. & 5.3 & 77. & 3511. & 0.54 & 0.09 \\
\hline 745 & 117 & 36. & 0.3 & Aम2. & no. & 55. & 87. & 5747 . & 0.58 & 0.04 \\
\hline 615 & 150. & 42. & 0.3 & 875. & 61. & 57. & 97. & 7676. & 0.61 & 0.02 \\
\hline 845 & 1 ค9. & 51. & 0.3 & R73: & 62. & 59. & 105 & 8951. & 0.57 & 0.02 \\
\hline 915 & 198. & 48. & 0.2 & BRB. & & 60. & 104. & 8638 . & 0.52 & 0.01 \\
\hline $\begin{array}{r}945 \\
1015\end{array}$ & $\begin{array}{l}219 . \\
273 .\end{array}$ & 66. & 0.3 & 867. & 64. & 61. & 107. & 8970 . & 0.49 & 0.01 \\
\hline $\begin{array}{l}1015 \\
1045\end{array}$ & $\begin{array}{l}2730^{\circ} \\
274 .\end{array}$ & 96. & $\begin{array}{l}0.3 \\
0.3\end{array}$ & $8+0$. & 65. & 63. & 1160 & 105 Ko. & 0.46 & 0.01 \\
\hline $\begin{array}{l}1045 \\
1115\end{array}$ & $2 ? 4$ & 96. & 0.4 & $\begin{array}{l}\text { 8h? } \\
\text { 459. }\end{array}$ & $\begin{array}{l}\text { hh. } \\
\text { hh. }\end{array}$ & $\begin{array}{l}64 . \\
64 .\end{array}$ & 121. & $\begin{array}{r}11307 . \\
9415 .\end{array}$ & $\begin{array}{l}0.49 \\
0.49\end{array}$ & $\begin{array}{l}0.01 \\
0.01\end{array}$ \\
\hline 1145 & 264. & e3. & 0.3 & 856. & 60. & 64. & 114. & 9456. & 0.44 & 0.01 \\
\hline 1215 & $3 n ו$. & 70. & $0 . ?$. & BSi. & 67. & 64. & 123. & 11494. & 0.45 & 0.01 \\
\hline 1245 & PRY. & 77. & 0.3 & 849. & 67. & 65. & 124. & 11537 & $0.4 \mathrm{H}$ & 0.01 \\
\hline 1315 & 254 . & H6. & 0.3 & 950. & 64. & 65. & 119. & 105440 & $0.4 y$ & 0.01 \\
\hline 1345 & 257. & 78. & 0.3 & 850. & 68. & 65. & 119. & 10475. & 0.48 & 0.01 \\
\hline 1415 & 237. & 77. & 0.3 & 852. & 68. & 65. & 119. & 10513 & 0.53 & 0.01 \\
\hline 1445 & 230 & 60. & 0.3 & 850. & 68. & 65. & 118 & 10249 & 0.53 & 0.01 \\
\hline 1515 & 197. & 48 . & 0.2 & 845. & 71. & 65. & 119. & 9656. & 0.58 & 0.03 \\
\hline 1545 & 144. & 41. & 0.3 & 842. & 73. & 66. & 115. & 8516. & 0.69 & 0.05 \\
\hline 1615 & 123. & 36. & 0.3 & 847. & 73. & 66. & 110 & 7548. & 0.73 & 0.06 \\
\hline 1645 & Hค. & 32. & 0.4 & 852. & 73. & 66. & 102. & 5943. & 0.81 & 0.09 \\
\hline 1715 & 56. & 29. & 0.5 & 854. & 73. & 65. & 92. & 3793. & 0.81 & 0.14 \\
\hline 174 & 27. & 24. & 0.9 & Bfi6。 & 72. & 65. & 82. & 2024. & 0.89 & 0.24 \\
\hline $\mid \mathrm{BI}$ & 19. & 19. & 1.0 & B十?. & 72. & 64. & 77. & 1096. & 0.72 & 0.41 \\
\hline 184 & A. & B. & & BRE. & 71. & 64. & 74. & 570. & 0.85 & 0.96 \\
\hline 1915 & l. & 1. & 1.0 & 870. & 70. & 62. & 71. & 176. & 1.65 & A. $3 n$ \\
\hline 1945 & 0 : & 0 . & 0.1 & 87?. & 711. & 61 & 69. & -33 & 0.00 & 0.00 \\
\hline 2015 & 0 . & 0 . & 0.1 & A7n. & 69. & & 64. & -tin. & 0.00 & 0.00 \\
\hline 2045 & 0 . & 0 . & 0.0 & 977. & GH. & no. & $G H$. & -40. & 0.00 & 0.00 \\
\hline 2115 & $n$. & 0 . & 0.0 & $87 K$. & $G H$. & 59. & 67. & -41. & 0.00 & 0.00 \\
\hline 2145 & $n$. & 0 . & 0.0 & R>Y. & 67. & • & 67. & -107 & 0.00 & 0.00 \\
\hline 2215 & 0 . & 0 . & 0.0 & s7n. & 67 . & 58. & tio. & -107 & 0.00 & 0.00 \\
\hline 2245 & 0. & 0 . & 0.0 & AH4. & i.7. & 58. & no. & $-1 i b$. & 0.00 & 0.00 \\
\hline 2315 & n. & 0 . & $n .0$ & 877. & to. & 54. & no. & -110 & 0.00 & 0.00 \\
\hline 2345 & 0 . & 0 . & 0.0 & $n$ & 0 & 0. & 0 & i). & ULuUuts & 0.00 \\
\hline
\end{tabular}


SOL AR

TIME

15
45
115
145
215
245
315
345
415
445
515
545

545

615

645

715

745

815

845

915

945

1015

1045

1115

1145

1215

as

6

6

(

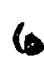

10

10

10

$1 \dot{0}$

1645
AIR INLET ANB IIUT

ITP IDP RD

$\begin{array}{lll}n \cdot & n \cdot n & n \\ n \cdot & 0 \cdot n & n \cdot 0\end{array}$

FLOW, TEMP

IEMP

7hit.

69.

38.

7nh.

60.

37 .

h7.

60. 37.

751 .

64.

37.

7 Thi

69.

37.

37 .

743.

69.

37.

753.

64.

38 .

753.

70.

39.

0 . 0.0

$n$.

3. $n .8$

75.3 .

70 .

39 .

68.

38.

7 ל4.

70 .

39.

40.

71.

19. 0.4

$30 . \quad 0.4$

39. 0.4

4.3. 0.3

$44 . \quad n .2$

67. 0.6

72. $\quad 0.4$

74. 0.3

8. 0.3

98. $\quad 0.4$

$90 . \quad 0.3$

13. n.2

69. 0. ?

ह1. 0.3

89. 0.3

74. 0.3

60.0 .3

40.0 .2

40. 0.2

31.0 .2

740 .

73.

42.

78.

$\begin{array}{llll}735 . & 83 . & 43 . & 109 . \\ 729^{\circ} & H 0_{0} & 44 . & 124 .\end{array}$

$7>2$.

91.

45.

137.

728 。

92.

46. 132 .

46. 124.

$7>4$.

714.

RH.

48 .

149.

97.

49. 156.

51. 157 .

51. 152 .

712 .

98.

53. 165 .

54. 173.

55. 170 .

56. 165.

56. 160.

57. 158.

$\begin{array}{llll}700 . & 49 . & 57 . & 158 . \\ 710 . & 98 . & 56 . & 150 .\end{array}$

1615 124.

9.3.

36. 0.4

21. 0.5

19. 0.7

7. 1.0

1.0 .5

0.0 .0

0 . 0.0

0.0 .0

0 . $0 . n$

0 . 0.0

0 . 0.0

0.0 .0

0 . 0.0

0.0 .0

707 .

QR.

56.145.

711 .

91 .

55. 125 .

712 .

87.

54. 110.

53.93.

719.

$7>?$.

SO.

52.

83.

720.70

50. 77 .

49. 75.

47.74.

46.73.

45.

73.

$7>8$.

T>⿱一𫝀口.

$7>\mathrm{H}$.

$7 ? 1$.

$7>R$.

739.

75.

75.

75 .

44.

43.

43.

42.

42

75.

o.

0 .
47.

67.

67.

67.

37 .

67 .

67.

67.

68 .

93.

QU

\section{EFF DT/I}

$$
-407 . \quad 0.00 \quad 0.00
$$

$-409.0 .00$

$-417 . \quad 11.00$

$-415.11 .00$

$-415.0 .00$

$-415.0 .00$

$-412.0 .00$

$-410.0 .00$

$-4 n 2 . \quad 0.00$

-325. 0.00

$-377 . * 0$

$-2+30-0.77$

20. 0.02

1025.0 .26

2866. 0.41

$47 n 2.0 .51$

6403.0 .59

$7932 . \quad 0.50$

7098 . 0.71

63P1. 0.44

$9703 . \quad 0.43$

10332.0 .47

10203.0 .49

9597.0 .43

11337.0 .42

$12047: 0.46$

11574.0 .48

10912.0 .51

10431.0 .53

9977. 0.53

9942.0 .58

8976. 0.65

8377.0 .79

5774.0 .83

3859. 1.04

1743.0 .82

6R 1.1 .07

1. 0.01

$-214 . \quad 0.00$

-31 ?. 0.00

$-345 . \quad 0.000$

-365. 0.00

$-377.0 .00$

$-384.0 .00$

$=305.0 .00$

$-4 n 3 . \quad 0.00$

$-412.0 .00$

0. usisusus

72.

0 .

0.00

0.00

0.00

0.00

0.00

0.00

0.00

0.00

0.00

112.10

7.70

1.96

0.70

0.43

0.36

0.33

0.24

0.38

0.24

0.17

0.18

0.19

0.17

0.14

0.16

0.17

0.18

0.19

0.19

0.21

0.25

0.32

0.43

0.75

1.17

3.79

29.67

0.00

0.00

$0: 00$

0.00

0.00

0.00

0.00

0.00 
HALF-HOUDLY DATA SINMAWY FOH 4-15-79 DAY MOI. IOS

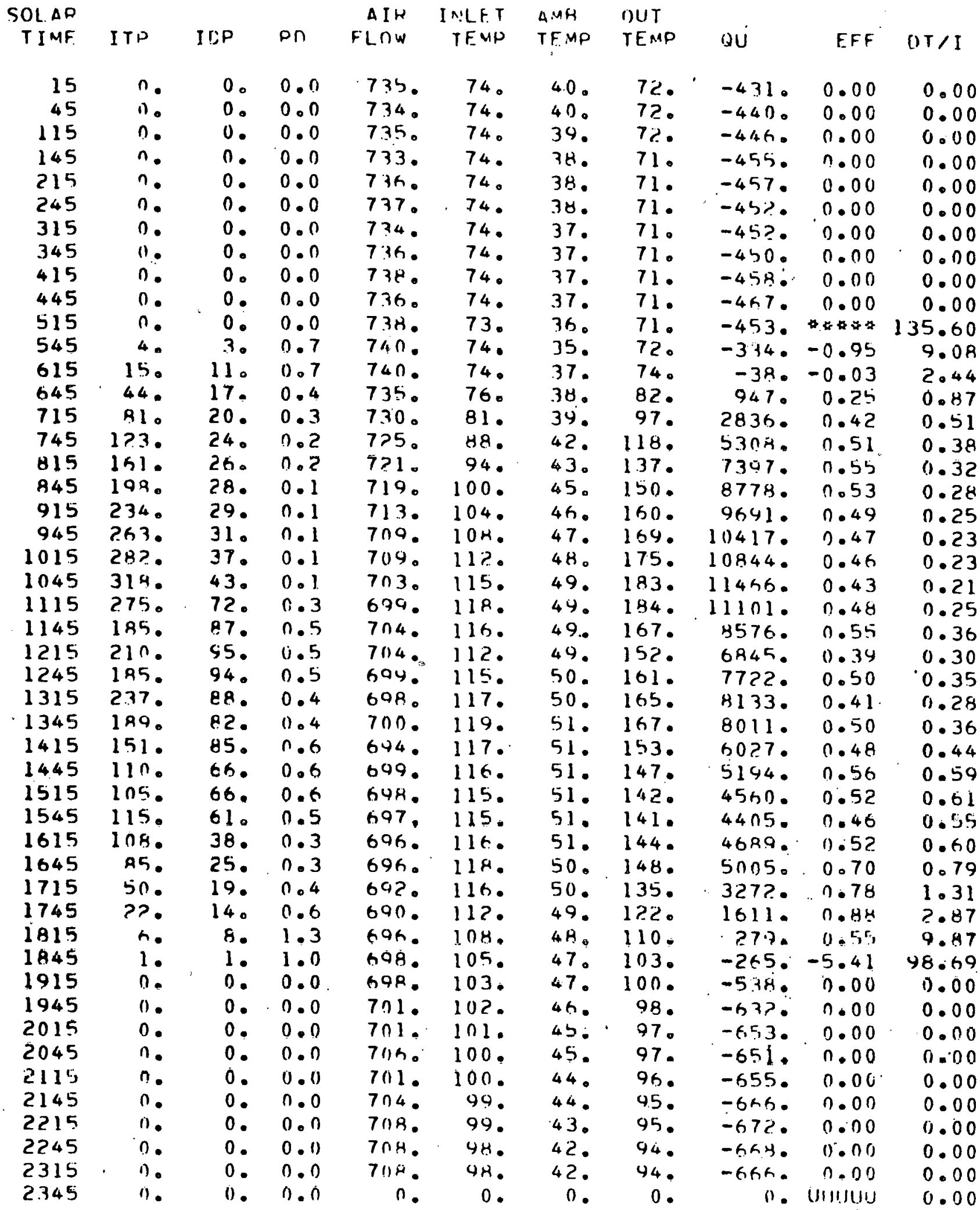




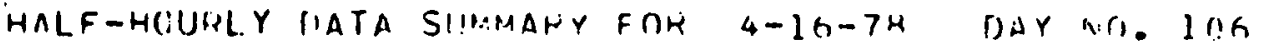

\begin{tabular}{|c|c|c|c|c|c|c|c|c|c|c|}
\hline $\begin{array}{l}\text { SOLAE } \\
\text { TIME }\end{array}$ & $I T D$ & ICP & R(1) & FLn' & $\begin{array}{l}\text { IA!LFT } \\
\text { TF:PAD }\end{array}$ & $\begin{array}{l}A M B \\
T F M A D\end{array}$ & $\begin{array}{l}\text { NUT } \\
\text { TEML }\end{array}$ & Q11 & EFF & DT/I \\
\hline 15 & 0. & 0. & 0.0 & 71.3. & 97. & 40. & 42. & -nष4. & 0.00 & $0.0 n$ \\
\hline 45 & 0. & 0 . & 0.0 & $71 ?$ & 90. & 40. & प. & $-6+4$. & 0.00 & 0.00 \\
\hline 115 & $n$. & 0 . & 0.0 & $7 \cap 9$. & gh. & 39. & 92. & -644. & 0.00 & 0.00 \\
\hline 145 & n. & 0. & 0.0 & 713. & 95. & 38 & 91. & -7100. & 0.00 & 0.00 \\
\hline 215 & $n$. & 0. & 0.0 & $71 ?$. & 05. & 38. & 91. & - 698. & 0.00 & 0.00 \\
\hline 245 & $n$. & 0 . & 0.0 & 714 & 94. & 38. & 90. & $-70 ?$ & 0.00 & 0.00 \\
\hline 315 & 0 & 0. & 0.0 & 715. & 94. & 38. & 90. & -703 & 0.00 & 0.00 \\
\hline 345 & 0. & 0 . & 0.0 & 714. & 94. & 37. & 89. & -7115 & 0.00 & 0.00 \\
\hline 415 & 0. & 0. & 0.0 & 712. & 93. & 37. & प्र9. & -705. & 0.00 & 0.00 \\
\hline 445 & $n$. & 0. & 0.0 & 717. & 93. & 36. & หy. & -71.3. & 0.0 .0 & 0.00 \\
\hline 515 & $n$. & 0 . & 0.0 & 7?1. & 92. & 36. & HE्C. & - 7กя. & 4640 & 205.51 \\
\hline 545 & 4. & 3. & 0.7 & 719. & 9?. & 35. & 89. & -545 & -3.68 & 13.43 \\
\hline 615 & 18. & 12. & 0.7 & 720. & 93. & 37. & 41. & -245 & -0.16 & 3.11 \\
\hline 645 & 4.3. & 17. & 0.4 & 717. & 94. & 38. & 98. & 547. & 0.16 & 1.30 \\
\hline 715 & 80 & 21. & 0.3 & 717. & 98 & 40. & 113. & 2456. & 0.37 & 0.73 \\
\hline 745 & lla. & 26. & 0.2 & 712 & 104. & 42. & 132. & 4672 & 0.48 & 0.54 \\
\hline 815 & $15 ?$. & 29. & 0.7 & 707. & 110. & 43. & 144. & 6633. & 0.52 & 0.44 \\
\hline 845 & 195. & 32. & 0.2 & $7 \cap$ ?. & 116. & 45. & 165. & 8253. & 0.50 & 0.36 \\
\hline 915 & $2 ? .4$. & 35. & 0.2 & 644. & 120 & 46. & 174. & 9091. & $0.4 \mathrm{~A}$ & 0.33 \\
\hline 945 & 271. & 49. & $0 . ?$ & 699. & 124 & 48. & 195. & 10247 & 0.45 & $0.2 \mathrm{~A}$ \\
\hline 1015 & 255. & 84. & 0.3 & 644. & 124 & 49. & 191. & 1.0675. & 0.50 & 0.31 \\
\hline 1045 & 205. & 75. & 0.4 & 695. & 126. & 50. & 176. & B297. & 0.48 & 0.37 \\
\hline 1115 & 337. & 92. & 0.3 & 642. & 131. & 51. & 199. & 11129. & 0.39 & 0.24 \\
\hline 1145 & 196. & 96. & 0.5 & 6A6. & 134. & 52. & 194. & 4874 & 0.60 & 0.42 \\
\hline 1215 & 96 & 80. & 0.8 & 64N. & 126. & 52. & 159. & 5319. & 0.66 & $0.7 \mathrm{H}$ \\
\hline 1245 & 158. & 86 . & 0.5 & 609. & 123. & 50. & 150. & $45 n 4$. & 0.34 & 0.46 \\
\hline 1315 & 195. & 99. & 0.5 & 697. & 128. & & 171. & 6977 . & 0.45 & 0.42 \\
\hline 1345 & 163. & 93. & 0.6 & 644 . & 129. & 51. & 168. & 64.33. & 0.47 & $11.4 \mathrm{H}$ \\
\hline 1415 & HG. & 66 . & $0 . A$ & $6 \times 4$. & 127. & 49. & 154. & 4448. & 0.62 & 0.91 \\
\hline 1445 & 130. & PG. & 0.7 & $6 \times 5$. & 125. & 49. & . & 4207. & 0.39 & 0.59 \\
\hline 1515 & 105 & 62 . & 0.6 & 695. & 127 & 49. & 155. & 4h? & 0.53 & 0.75 \\
\hline 1545 & 93. & 61. & 0.7 & 642. & 125. & 49. & 146. & 3423 . & 0.44 & 0.42 \\
\hline 1615 & 79. & 48 . & 0.6 & 647. & 126. & 49. & 147. & 3550 . & 0.53 & 0.97 \\
\hline 1645 & Au. & 41. & 0.5 & 694. & 125 & 49. & 146. & 3473. & 0.52. & 0.96 \\
\hline 1715 & 44. & 27. & 0.6 & 694. & 125 . & 48. & 140. & $26 \cap 8$. & 0.64 & 1.57 \\
\hline 1745 & P. & 19. & 0.7 & 69ח: & 122 & 4A. & 131. & 1457 & 0.62 & 2.67 \\
\hline 1815 & a. & 9. & 1.1 & Gan. & 118. & 47. & 119 & 186 & 0.29 & 9.37 \\
\hline 1845 & 1 . & 1. & 1.5 & Gan. & 115. & 46. & 113. & -406. & -0.70 & 96.29 \\
\hline 1915 & 0 . & 0 . & 0.0 & 642. & 113. & $4 b$. & 109. & -715. & 0.00 & 0.00 \\
\hline 1945 & $n$. & 0 . & 0.0 & hUo. & 112 & 44. & 107. & -793. & 0.00 & 0.00 \\
\hline 2015 & $n$. & 0 . & 0.0 & 60.3. & 111 . & 43. & 106. & $-8 \geqslant 6$ & 0.00 & 0.00 \\
\hline 2045 & 0 . & 0 . & 0.0 & 647. & 110. & 43. & 105. & -838. & 0.00 & 0.00 \\
\hline 2115 & 0. & 0. & 0.0 & 60?. & 110 & 42. & 105. & -840. & 0.00 & 0.00 \\
\hline 2145 & n. & 0 . & 0.0 & 606. & 109. & 42. & 104. & - Взи. & $0.0 n$ & 0.00 \\
\hline 2215 & $n$. & 0 . & $n .0$ & 605. & 104. & 41. & 101. & -975. & 0.00 & 0.00 \\
\hline 2245 & $n$. & 0 . & 0.0 & 647 . & 108. & 41. & 103. & $-8>1$. & 0.00 & 0.00 \\
\hline 2315 & $n$. & $n$. & 0.0 & 645. & 107. & 40. & 102. & -832. & 0.00 & 0.00 \\
\hline 2345 & 0. & 0 . & 0.0 & $n$ & 0 & 0 & 0 & $n$ & UIIU⿺𠃊U] & 0.00 \\
\hline
\end{tabular}




\begin{tabular}{|c|c|c|c|c|c|c|c|c|c|c|}
\hline $\begin{array}{l}\text { SOL.AQ } \\
\text { TIMF }\end{array}$ & ITP & ICP & p! & $\begin{array}{l}\Delta I^{D} \\
F L n !\end{array}$ & $\begin{array}{r}I N L+T \\
T E: T, N\end{array}$ & $\begin{array}{l}A \text { AB } \\
\text { TEMP }\end{array}$ & $\begin{array}{l}\text { 1)UT } \\
\text { TEMH }\end{array}$ & 110 & EFF & UT/I \\
\hline 15 & $n$. & 0 . & 0.0 & 700. & 106. & 39. & 101. & -8.28. & 0.00 & 0.00 \\
\hline 45 & $n$. & 0 . & 0.0 & $7 n 1$. & 106. & 34. & 101. & -834. & 0.00 & 0.00 \\
\hline 115 & $n$. & 0. & 0.0 & 7115. & 105. & 39. & 100 & -875. & 0.00 & 0.00 \\
\hline 145 & n. & 0 . & 0.0 & 704. & 105. & $7 \dot{x}$. & 190 & $-8>9$. & 0.00 & $0.00^{\circ}$ \\
\hline 215 & $n$. & 0 . & 0.0 & 704. & 104. & $3 *$. & 99. & $-R>4$. & 0.00 & 0.00 \\
\hline 245 & $n$. & 0. & 0.0 & $7 n 4:$ & 104. & 38. & 99. & $-8>3$. & 0.00 & 0.00 \\
\hline 315 & $n$. & 0. & 11.0 & 703 & 103. & 37 & Y4. & $-H>1$. & 0.00 & 0.00 \\
\hline 345 & $n$. & 0 . & 0.0 & $7 n 2:$ & 103. & 37. & वн. & $-k 15$. & $n .00$ & 0.00 \\
\hline 415 & 0. & 0. & 0.0 & 7117. & 102. & 37. & 97. & -タン0。 & 0.00 & 0.00 \\
\hline 445 & 0 . & 0 & 0.0 & 71 ?. & 102. & 36. & 97. & -833. & $0.0 n$ & 0.00 \\
\hline 515 & $n$. & 0. & 0.0 & 710. & 101. & 36. & 96. & $-8>0$. & 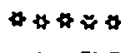 & 2.24 .56 \\
\hline 545 & 5 & 4. & 0.8 & 709. & 101. & 35. & 97. & $-6 \times 0$. & -1.55 & $12 \cdot 52$ \\
\hline 615 & 17. & 13. & $n \cdot R$ & $7 \cap 6$. & 101. & 36. & 99. & -357. & -0.24 & 3.73 \\
\hline $\begin{array}{l}645 \\
715\end{array}$ & $4 n_{0}$ & 23. & 0.6 & $7 \cap 5$. & 103. & 37. & 105. & 345. & 0.10 & 1.64 \\
\hline 715 & 76. & 28. & 0.4 & 707. & 106. & 39. & 118. & 2010. & 0.32 & 0.88 \\
\hline 745 & 115. & 29. & 0.3 & $7 \cap G$. & 112. & 42. & 137. & 4330. & 0.45 & 0.61 \\
\hline 815 & 155 & 32. & 0.2 & $7 n \ddot{~}$ & 117 & 43. & 157. & $67 n 5$. & 0.52 & $0.4 R$ \\
\hline 845 & 191. & 33. & i).? & 700 & 118. & 43. & 167. & 8185. & 0.51 & 0.39 \\
\hline 915 & $2 ? 5$. & 36. & $0 . ?$ & 7111. & 120. & 44. & 175. & 9105. & 0.49 & 0.34 \\
\hline 945 & 251. & 38. & 0.2 & 701 . & 122. & 45. & 181. & 902 . & 0.47 & 0.31 \\
\hline 1015 & 277 & 39. & 0.1 & $7 n 1$. & 125. & 46. & 147. & 10444. & 0.45 & $n .29$ \\
\hline 1045 & 301. & 39. & 0.1 & 67h. & 129 & 40. & 194. & 10924. & 0.43 & 0.27 \\
\hline 1115 & 315. & 40. & 0.1 & 640. & 132. & 47. & 199. & 11218 & 0.42 & 0.27 \\
\hline 1145 & 321. & 42 . & 0.1 & 641. & 135. & 48 & 203. & 11397 . & 0.42 & 0.27 \\
\hline 1215 & $3 ? n$. & 42. & $n \cdot 1$ & $6 \times 5$. & 137. & 49. & 207. & 11449. & 0.43 & 0.28 \\
\hline 1245 & 315. & 42. & 0.1 & $6 \times 1$. & 137. & 50. & 209. & 11717. & 0.44 & 0.28 \\
\hline 1315 & 304. & 410 & 0.1 & 640. & 134. & 50 . & 204. & 11599. & 0.45 & 0.28 \\
\hline 1345 & 290. & 38. & 0.1 & 640. & 132. & 50. & 201 & $113 n 1$. & 0.47 & 0.28 \\
\hline 1415 & $2+7$. & 39. & $1) \cdot 1$ & 693. & 131. & 50. & 199. & 11146. & 0.50 & 0.30 \\
\hline 1445 & 232 & 48. & $n \cdot 2$ & GAB. & 129. & 50. & 19.3. & 10556. & 0.54 & 0.34 \\
\hline 1515 & 1.77 & 54. & 0.4 & 699. & 125. & 50. & 176 & 8340 & 0.72 & 0.55 \\
\hline 1545 & 114 & 6.5. & 0.0 & 672. & 118. & 49. & 153 & $5 \overline{8} 51$. & 0.61 & 0.60 \\
\hline 1615 & 47. & 46. & 11.5 & 606. & 115. & 49. & 140. & 5112. & 0.70 & 0.76 \\
\hline 1645 & 4?. & 34. & 0.8 & 692. & 111. & 49. & 126. & 25116. & 0.71 & 1.49 \\
\hline 1715 & ?8. & 24. & 0.4 & SOA. & 104. & & 115 & 1.300. & 0.56 & 2.13 \\
\hline 1745 & 16 & 13. & 0.9 & 700. & 105. & 47 & 108. & bo?. & 0.38 & 3.53 \\
\hline 1815 & no & 5. & $n .9$ & 697. & 103. & 47. & 103. & 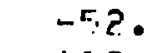 & -0.10 & 9.33 \\
\hline 1845 & n. & 0. & 0.0 & 701. & 101. & 46. & 99. & -413 & $4 * 4$ & 120.13 \\
\hline 1915 & $n$. & 0 & $n \cdot n$ & 703. & 100 & 45 & 97. & $-57>$ & 0.00 & 0.00 \\
\hline 1945 & $n$. & 0. & 0.0 & $7 n h$. & 99. & 44. & 96. & $-6>0$. & 0.00 & 0.00 \\
\hline 2015 & $n$. & 0. & 0.0 & $7 \cap 7$. & 94. & 44. & 45. & -635. & 0.00 & 0.00 \\
\hline 2045 & $n$. & 0. & 0.0 & $7 \cap 7$. & $9 B$. & 44. & 94. & $=n .3 .7$. & 0.00 & 0.00 \\
\hline 2115 & $n$. & 0 。 & 0.0 & 703 & 98. & 44. & 94. & $-6 ? 7$. & 0.00 & 0.00 \\
\hline 2145 & $n$. & 0 . & 0.0 & 717. & $9 H$. & 44. & 94. & -641. & 0.00 & 0.00 \\
\hline 2215 & $n$. & 0 . & 0.0 & 7119. & 47. & 44. & 44. & $-6>n$. & 0.00 & 0.00 \\
\hline 2245 & c. & 0. & 0.0 & $7 \cap 9$. & 97. & 44. & 93. & $-6>5$. & 11.00 & 0.00 \\
\hline & 11 & 0 . & $n \cdot n$ & $7 \cap 9$. & 97. & 44. & 33 & $-6 ? 1$. & 0.00 & $0.11 n$ \\
\hline 145 & $n$. & 0 . & 0.0 & 0. & 0 & 0 & 0 & 0 & (1יו!)uU & 0.00 \\
\hline
\end{tabular}




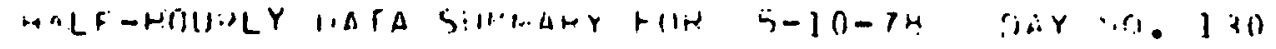

SOI. 60

TINF

IT⿱

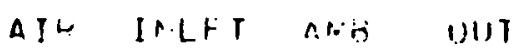

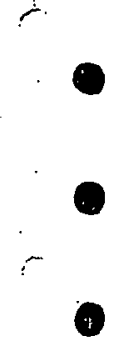

15

$$
0.0 .0 .01
$$

45

n.

). 11.11

115

?15

245

315

145

415

445

515

545

615

645

715

745

+1 15

845

915

945

11) 15

1045

1115

1145

1215

1245

1315

1345

1445

1515

1545

1615

1645

1715

1745

$1 \times 15$

$1+445$

1415

$1+45$

2015

2. 045

2115

2145

टखाम

2श45

2314

234 !

i. 0.0 .11

n. $0.0 . n$

is

$n$.

0.0 .0

0.0 .0

0.0 .0

$n$.

$0 . n .0$

n. 0.0 .0

3. 1.0 .5

4. 6. 0.7

?3... 19. ก.H

34. 24. n.4

A1.

117

40.

41. 0.4

$\leq 0.0 .4$

59. n.t

to. U.h

54.11 .4

H4. ก. 7

ห.

194.

10h. 0.5

215. 103. n.5

ลேン.

96.

n. 4

2?11. 101.0 .4

184.

$25 \%$.

251.

101.

ㄷ․ 0.3

ค. . 0.3

77. 0.4

66.0 .5

64.0 .3

50.11 .4

1??.

Ph.

A.

5?.

4 ?

36.0 .4

$25 . .0 .5$

25.

¿. 0.8

12. 13. 1. 1

i. 7.1 .4

i). 0.0 .4

i. 0.0 .4

11. 0.11 .4

ก. $n .11 .4$

!. 0.0 .3

i1. $\quad 0.4 .3$

1. 0.0 .2

ci. 0.11 .7

n. 0. il.?

$n$. $\begin{array}{ll}0 . & n+. \\ 11 . & 11 . \\ 11 . & 61 . \\ 11 . & n 1 . \\ 11 . & n 1 . \\ 0 . & n 1 . \\ 0 . & 40 . \\ 0 . & 60 . \\ 1 . & 59 . \\ 0 . & 50 .\end{array}$

n. 54 .

i. 24.

0.54.

n.
0.5

0.5

11.5

541.

843.

893.

भपषप.

A. 1 .

Bบ?

ANA.

479.

87.

4t5.

Rค 7 .

คน 7 .

Shll.

Hinh.

Afic.

859.

857.

455.

BKI!

RG?.

Q⿻4.

$87 ?$

877.

Hल0.

मㄱ․

ค::4.

H.d.

HW 7 .

Kal

aisil.

Q i ; 2 .

Hit.

4: $)$

11.

59.

61.

no

h)

53.

63.

64.

tho.

r.t.

57 .

64.

64.

711.

71.

$7 ?$.

72.

72 .

73.

73.

73.

73.

72.

72.

71.

711.

711.

hy.

hH.

GH.

07.

t. 7 .

t:t:

his.

1).

1). 1

il. nu.

h1. nd.

m. $=0$.

पil. कH.

b1).

50.

51.

गH.

SH.

57.

50.5 .

50. 57.

50.57.

51.

5.1 .

52 .

59.

59.

83.

51.

54.

5

Q0.

44.

मत.

5) मर.

50. म्र०.

56 .

if.

iy.

ho.

6.1.

62.

ho.

24.

45.

104.

115.

114.

114.

117.

119.

113.

66. 104.

66. 111.

67. 1118.

67.

67 .

$94:$

47.

n.

t.6.

41.

4).

sri.

n5.

76.

64.

73.

n.

ni?

hi.

71.

ac.

Gr.

su.

=․

ค․

n.

$\rightarrow 40$

57.

i7.

t.t.

oto.

h5.

i).

!)

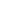




\section{MODEL SEC-601 COLLECTOR EFFICIENCY.}

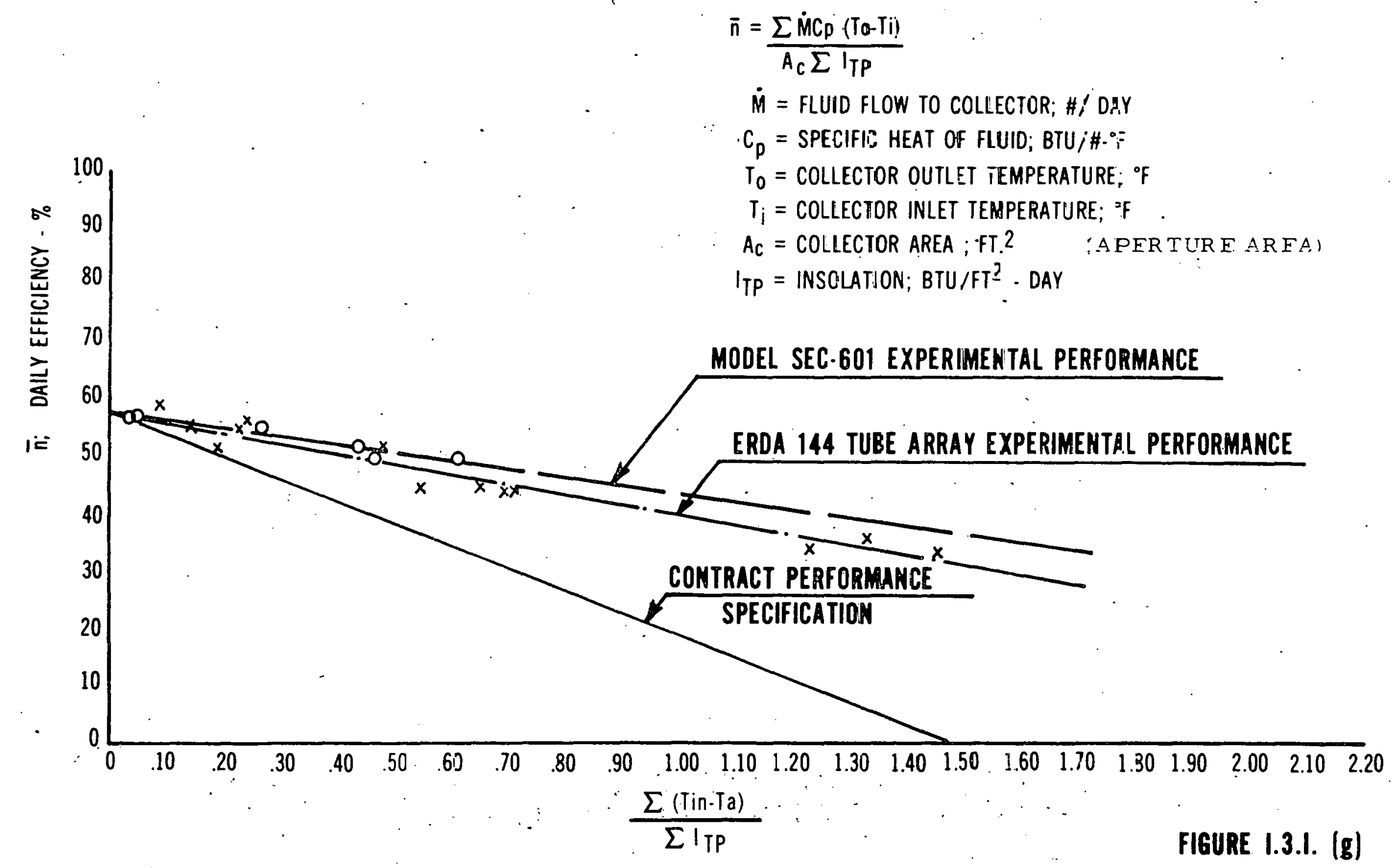




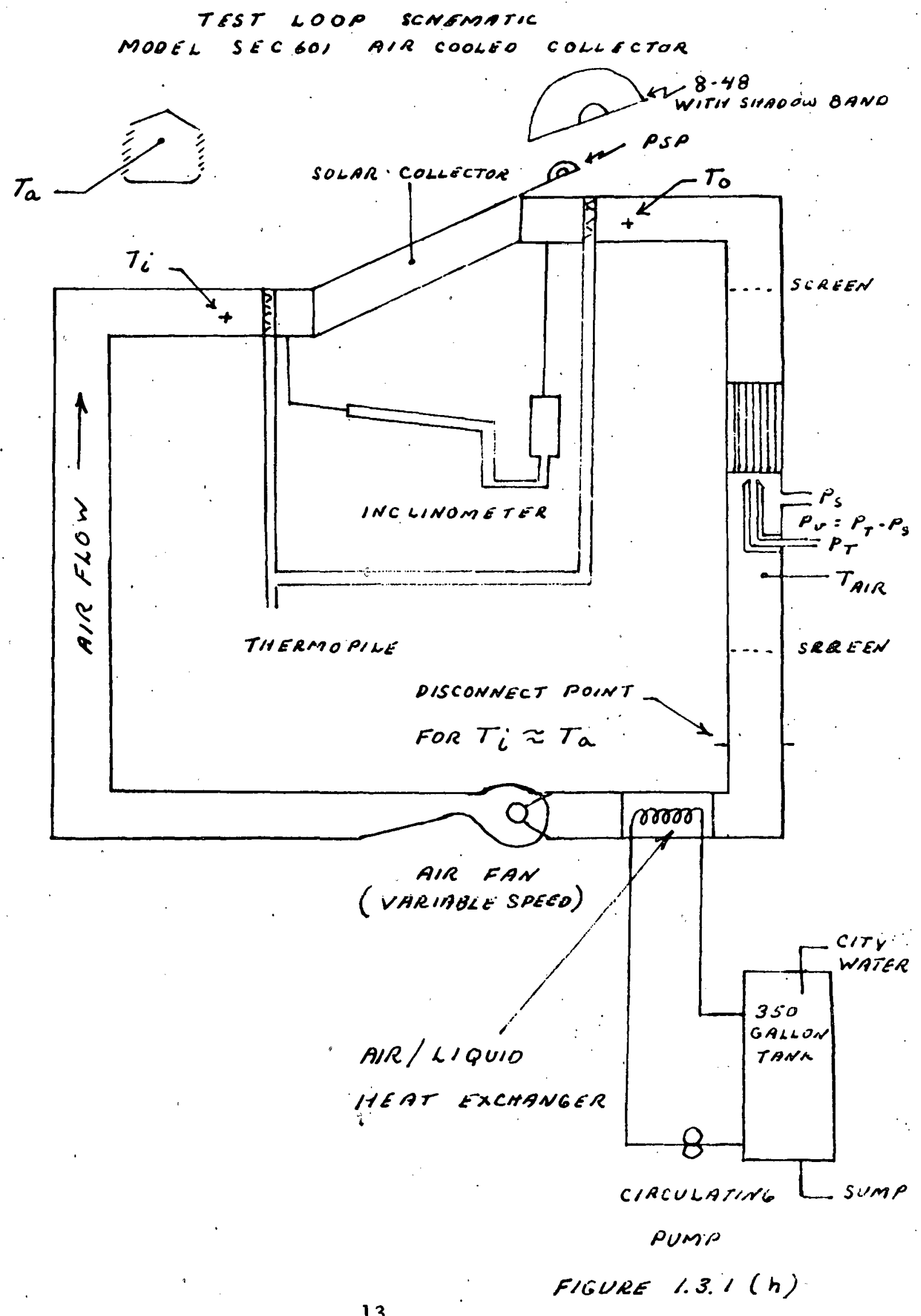


OUJEASS-1LHSUOSS

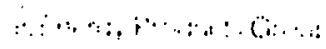

February 28,1978

Intra-Company

io G. R. Mather : Dev. Ctr.

subject

CC: K. L. Moan - Dev. Ctr.

Y. K. Pei - Dev. CEr.

L. Spanoudis - Dev. Ctr.

H. J. Zitkus - NTC

SPECTRAL PROPERTIES OF A WHITE BACKGROUND MATERIAL

A white corrugated aluminum background was installed at the Develupment Center in February 1978. The materid] was Alcoa Bone White [K-2028, Desoto Paint].

Reflectance measurements were made on the sample as received. The reflectance was calculated using ASTI Designation E-424-71 (with a barium sulfate standard instead of magnesium oxide). The spectral curves are in our file.

Alcoa Bone White, Total Reflectance 78.57 .

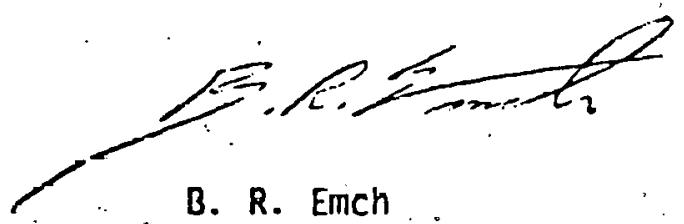

BRE:gS

FIGURE 1.3.1(i) 


\section{OWENS-HLLIOIS}

Corporits Technokgy

Toledo, Chio

Septeniber 14, 1976

\section{Intra-Company}
to A. Lewis
subject Report of Calibrotion Type "T" Thermocouples
Designation: $R O B-4-976$

Calibration was performed on 35 Type " $T$ " copper-constantan thermocouples at $32^{\circ} \mathrm{F}, 175^{\circ} \mathrm{F}$, and $350^{\circ} \mathrm{F}$. The $32^{\circ} \mathrm{F}$ poini was determined by inrersing the thermocouples in melting ice. The $175 \%$ and $3150 \%$ pcisits Here deterinined using a Rosemount oil both, Muellar bridge, and a platinum resistance thermoineter reference standard, $S / N$ 1739336. The thernocouples. were referenced to $32^{\circ} \mathrm{F}$ with a kaye Ice Point Reference systom and their enf was measured on a $L 8 N 7556$ potentioneter. The calibration is referenced to the IPTS 63 , and is traceable to the National Bureau of Standards.

The temperature deviation of all 35 thermocouples is approximately the same for each point,..1 $1^{\circ}$ high at $32^{\circ} \mathrm{F}, .2^{\circ}$ low at $175^{\circ} \mathrm{F}, .7^{\circ}$ low at $350^{\circ} \mathrm{F}$. The uncertaintics of these values are estimated not to exseed $.1^{\circ} \mathrm{F}$ at $32^{\circ} \mathrm{F}$ and $175^{\circ} \mathrm{F}$ and $.2^{\circ} \mathrm{F}$ at $350^{\circ} \mathrm{F}$.

Calibration Test Performed by

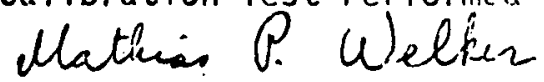

Instrument Services Standards Lab 
Table 1

RDS $-1-976$

Temperature

$32^{\circ} \mathrm{F}$

$75^{\circ} \mathrm{F}$

$350^{\circ} \mathrm{F}$

T.C.

T.c. Rociding "F

T.C. Peading "F

T.C. Roading \%

1
2
3
4
5
6
7
8
9
10

32.1

$3 \% .1$

32.1

32.7

.37 .1

32.1

32.1

32.1

32.1

32.1

32.1

32.9

32.1

32.1

32.1

32.1

32.1

32.1

32.1

32.1

32.1

32.1

32.1

32.1

32,1

32.1

32.1

32.1

32.1

32.1

32.1

32.1

32.1

32.1

$3 ?, 1$

174.8

171.8

174.8

174.8

174.8

174.8

174.8

174.8

174.8

174.3

174.8

174.8

174.8

174.3

774.8

174.8

171.8

174.8

174.8

174.8

174.8

174.8

174.8

174.8

174.3

174.8

174.8

$1 \% 4.8$

174.3

174.8

174.83

174.3

174.8

174.8

174. is
349.3

319.3

349.3

349.3

349.3

349.3

349.3

349.3

349.3

349.3

319.3

349.3

319.3

319.3

349.3

$54 \% .3$

349.3

349.3

349.3

349.3

349.3

349.3

349.3

349.3

349.3

349.3

3.59 .3

34.9 .3

. 349.3

319.3

349.3

349.3

319.3

349.3

349.3

FIGURE $1.3 .1(\mathrm{j}) 2$ OF. 


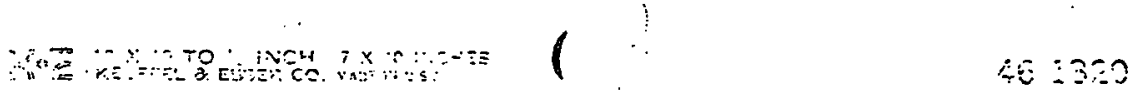

Test Designation ROB -4-976 $8-13-16$

.3 Temp of us Deviation of Thern-couplos ( F F Note: This graph is based on the average values of 35 Therme-

.2 couples before these values were rounded off.

$$
+.1
$$

$$
0
$$

$-.1$

.2

no

ค.

.6

.7

.8 9

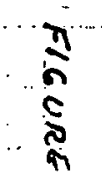

$8 \cdots$

1.0

50

$100 \quad 150$

200

300

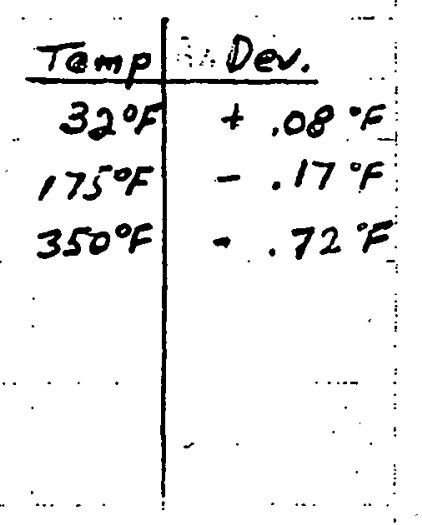




\section{OWENS-ILUNOIS}

Corporate Technology

Toledo. Onio

June 29, 1977

Intra-Company

to K. Moan - Dev Ctr

subject

CC: D. Stahl - NTC

\section{FLUKE CALIBRATION}

On May 12. 1977 the six month intcrnal calibration check was completed for the Fluke data acquisition system. The test was performed using a Leeds $\varepsilon$ Northrup millivolt potentiometer balanced to a standard reference cell. The following results were obtained and are within the instrument specifications.

STANDARD MV

$1.000 \mathrm{MV}$

$10.000 \mathrm{MV}$

$30.000 \mathrm{MV}$

\section{FLUKE}

$1.001 \mathrm{MV}$

$10.005 \mathrm{MV}$

$30.011 \mathrm{MV}$

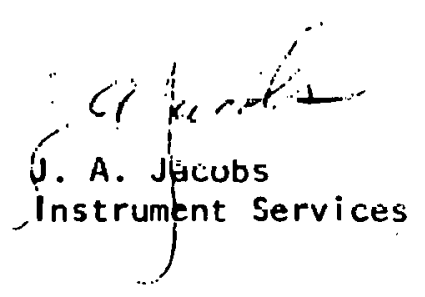

FI.6URE/3.1(K) $10 * 3$ 


\section{OWENS-ILUNOIS}

Corporate Technology

Toledo, Ohio

October 24, 1977

Intra-Company

10

K. Moan - Dev. Ctr.

subject

cc: D. Beekley - Dev. Ctr.

D. Stahl - NTC

\section{FLUKE CALIBRATION CHECK}

On October 21, 1977 a calibration check was completed on the Fluke data system used for solar monitoring. The test was performed using a Leeds and Northrup millivolt potentiometer referenced to a standard cell. The following results were obtained and are within the instrument specifications.

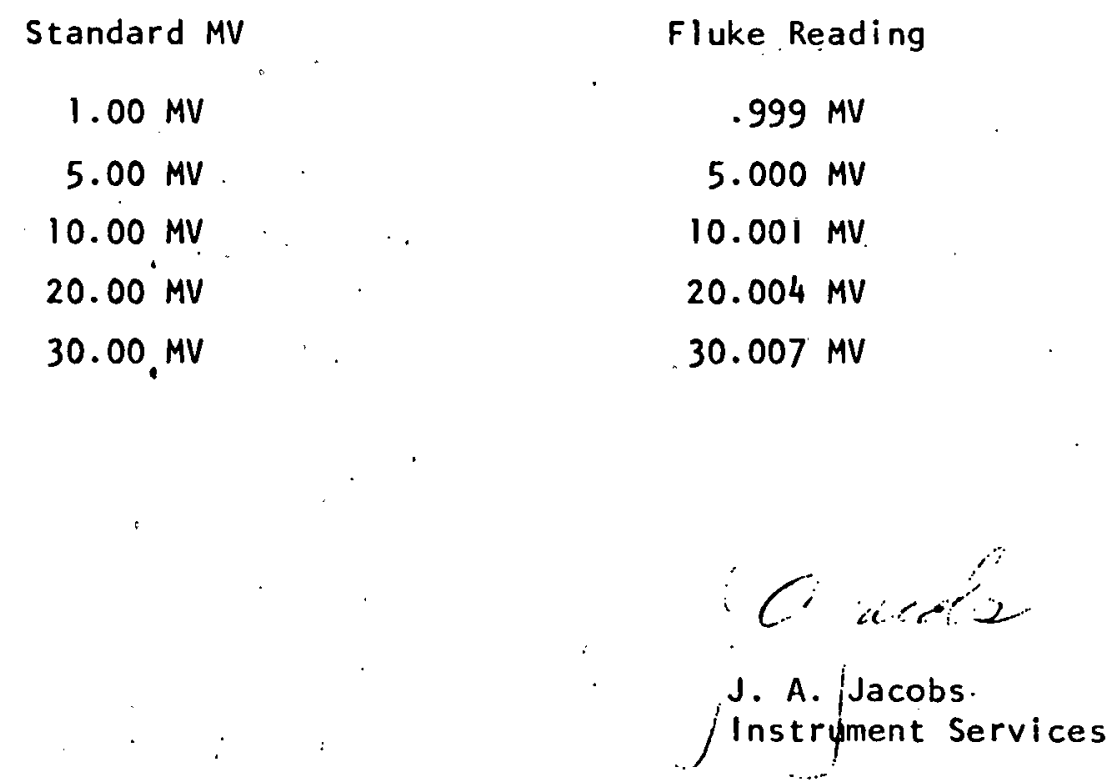

FIGURE 1.3.1 (K) 2 OF 3 


\section{OWENS-ILINOIS}

Corporate Technology

Toledo, Ohio

May 4,1978

Intra-Company

10 K. Moan - Dev. Ctr.

subject

CC: D. Beekley - Dev. Ctr.

D. Stahl - NTC

\section{FLUKE CALIBRATION .CHECK}

On May 4, 1978 a calibration check was completed on the Fluke data systom uscd for SUIJPAK monitnring at the Development Center. The test was performed using a Leeds and Northrup millivolt potentiometer referenced to a standard Cell. The following results are within the instrument speclfications.

Standard MV
$1 \mathrm{MV}$
$5 \mathrm{MV}$
$10 \mathrm{MV}$
$20 \mathrm{MV}$
$30 \mathrm{MV}$

$$
\begin{aligned}
& \text { Fluke Rieading } \\
& 1.000 \mathrm{IIV} \\
& 4.999 \mathrm{IVV} \\
& 10.003 \mathrm{MV} \\
& 20.007 \mathrm{MV} \\
& 30.016 \mathrm{MV}
\end{aligned}
$$

J. A. Jacobs

Instrument Services 


\title{
EPPLEY PRECISION PYRANOMETER
}

(horizontal surface receiver-180. twin hemisphere)

\begin{abstract}
Model PSP
\end{abstract}

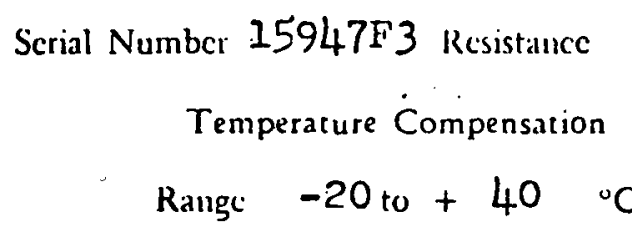

615 ohm at

$26{ }^{\circ} \mathrm{C}$

This radiometer has been compared with the Eppley group of reference standards. under radiation intensities of about 700 watts meter 2 (roughly. one-half a solar constant). the adopted calibration temperature is $27^{\circ} \mathrm{C}$.

As a result of a series of comparisons, it has been found to develop an emt of:

$$
\begin{aligned}
& \text { mV } \times 2^{2} 6.7 / 5 \%=8 \pi \% / \% 10.32 \times 10.6 \text { volts } / \text { watt meter }{ }^{2} \\
& 7.20 \text { millivolts } / \mathrm{cal} \mathrm{cm}^{2} \mathrm{~min} \cdot 1
\end{aligned}
$$

The calculation of this constant is based on the fact that the relationship between radiation intersity and emf is rectilinear to intensities of 1400 watts meter-2. This pyranometer is linear to within \pm 0.5 percent up to this intensity.

The calibration was made with both hemispheres of Schott WG295.(clear) glass. This value should be increased for other Schott hemispheres as follows: GG400 $=0.0$ $\% .0 G 530=0.5 \%, R G 610=1.5 \%$ and $R G 695=2.0 \%$.

The calibration of this instrument is traccable to standard self-calibrating cavity pyrheliometers in terms of the Systems Internationale des Unites (SI units), which participated in the Fourth International Pyrheliometric Comparisons (IPCIV) at Davos, Switzerland in October 1975.*

$\begin{array}{ll}\text { Useful conversion facts: } & 1 \mathrm{cal}-\mathrm{cm}^{-2} \min ^{-1}=697.3 \text { watts } / \text { meter }^{2} \\ & 1 \mathrm{BTU} / \mathrm{ft}^{2} \cdot \mathrm{hr}^{-1}=3.153 \text { watts } / \text { meter }^{2}\end{array}$

Date of 'Test: JuIJ 6, 1977

IN CHARGE OF TEST

The Eppley Laboratory, Inc.

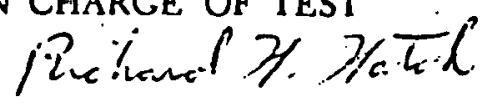

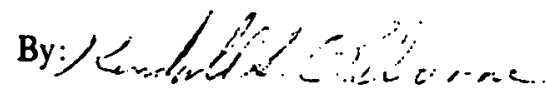

Newport, R. I.
S. O. 35000

Date July 15, 1977

Shipped to: Owens Illinois Devcloprent Centei ríledo, Ohio 


\section{Explanation of cliange in calibiation traccability}

As of April 1, 1977, the calibration traceubility' of F.ppley solar radiation measuring; instruments has been changed from the International Pyrlicliometric Scalc of 1956 (It'S 1956) to the Absolute Scale (SI). This chauge based on the results of IPC IV is such that instruments calibrated in SI units vicld irradiance values which arc $2.1 \%$ higher than values which would be obtained using Epplcy instruments calibrated previously and referenced to IPS. 
EPPLEY PRECISION SPECTPAL

PYRANOMETER-MOOEL PSP INSTRUNENT NO $15947^{\circ}$

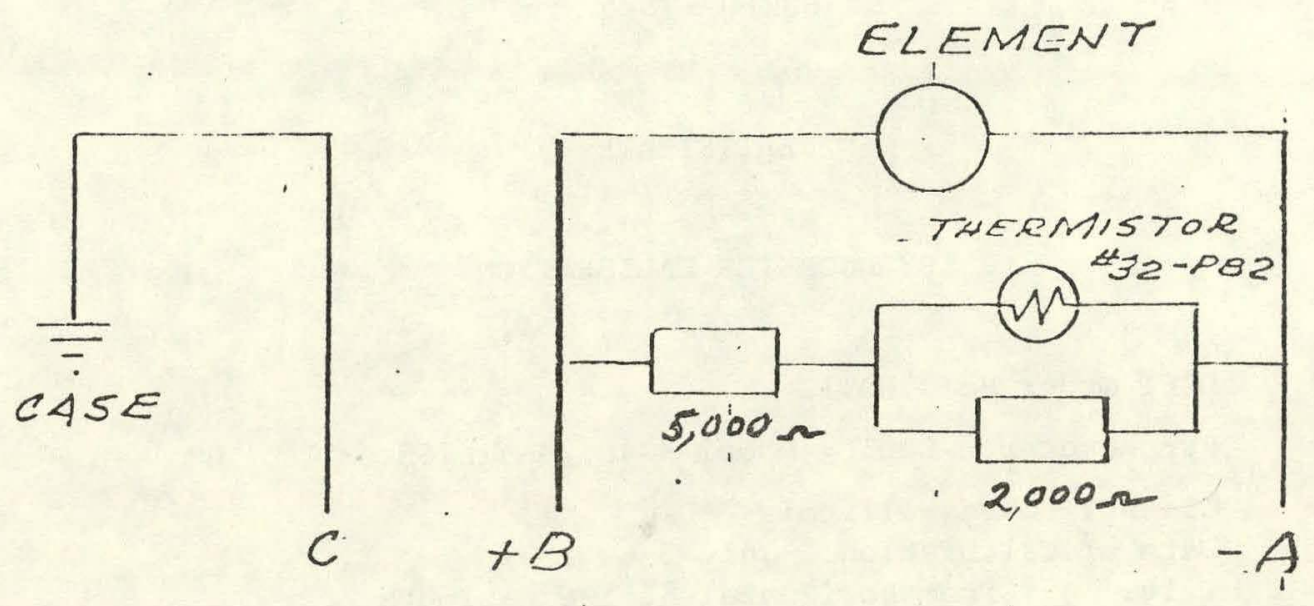

INTERNAL MIRING

TEMPERATURE DEPENDENCE

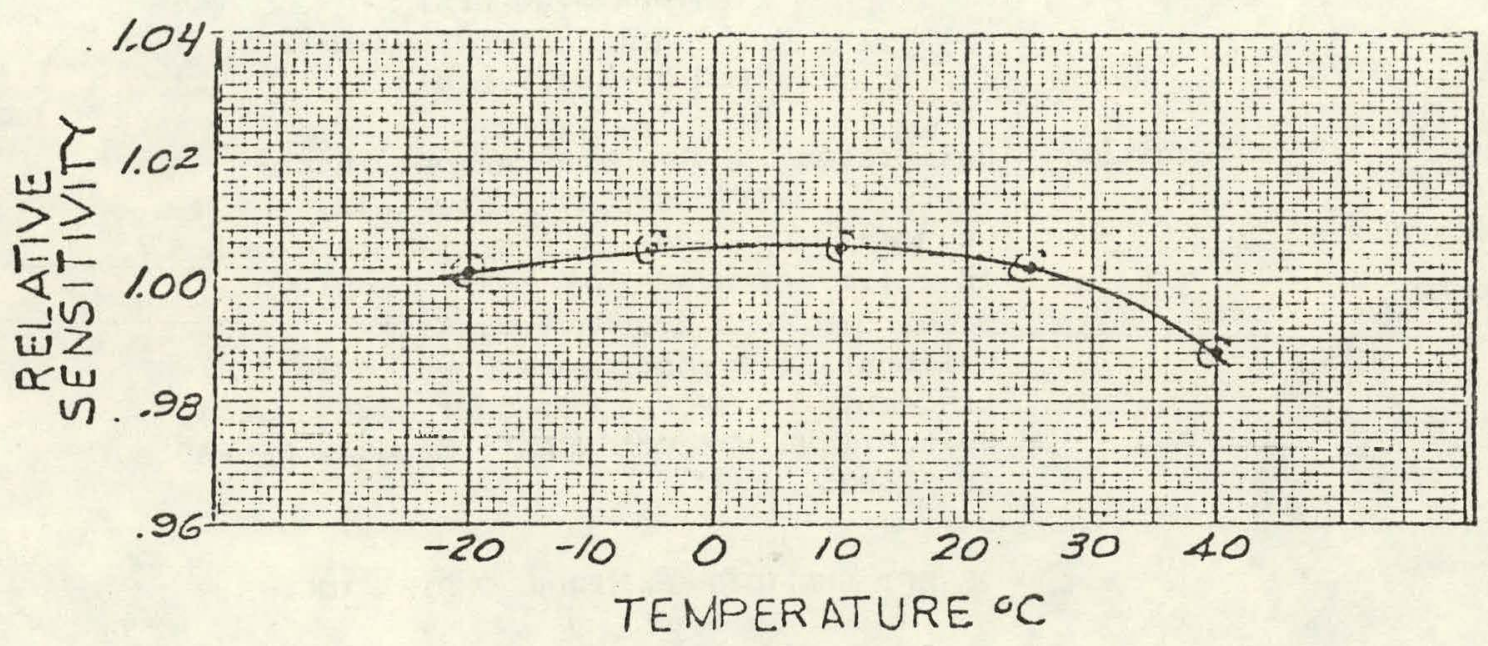

IESTED SY,
DTE JULY 1,1977

FIGORE 1.3 .1 (R) $30 \% 3$. 


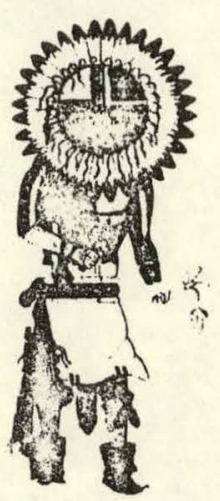

TAWA.

IHE SUN KACHINA

\section{We Test Anything Zinder the Sun}

BOX $185 \bullet B L A C K$ CANYON STAGE

PHOENIX, ARIZONA 85020

(602) 465-7525

\section{CERTIFICATE}

$\mathrm{OF}$

\section{PYRANOMETER CALIBRATION}

DSET Order No. $18011 \mathrm{C}$

Pyranometer: Eppley Mode1 8-48, SN 15765

Client: Owens-Illinois

Date of Calibration: July 5-6, 1977

Tilt: $45^{\circ}$ from horizontal at $180^{\circ}$ azimuth Latitude: $33^{\circ} 50^{\prime}$

Time: 10:00 to 15:00 hrs apparent solar

Scale: Absolute

Ambient Temperature: $36.7^{\circ} \mathrm{C}-42.2^{\circ} \mathrm{C}$

$$
\begin{aligned}
\text { INSTRUMENT CONSTANT: } \quad & 8.405 \times 10^{-6} \pm 0.01 \mathrm{~V} / \mathrm{wm}^{-2} \\
& (10: 00-15: 00 \mathrm{hrs}) \\
8 . & 357 \times 10^{-6} \pm 0.01 \mathrm{~V} / \mathrm{wm}^{-2} \\
& (10: 30-13: 30 \mathrm{hrs})
\end{aligned}
$$

Traceability: Calibrated in 60 instantaneous increments to DSET's Eppley PSP working standard (SN 14391F3) itself maintained in valibration aydinst DSE'I's Eppley Model H-F Absolute Cavity, SelfCalibrating Pyrheliometer, which is traceable to IPC IV, Octoher 1975, Davos, Switzerland through NOAA's Kendall PACRAD SN 67502 .

DESERT SUNSIINT: EXPOSURE: TESTS, TNC.

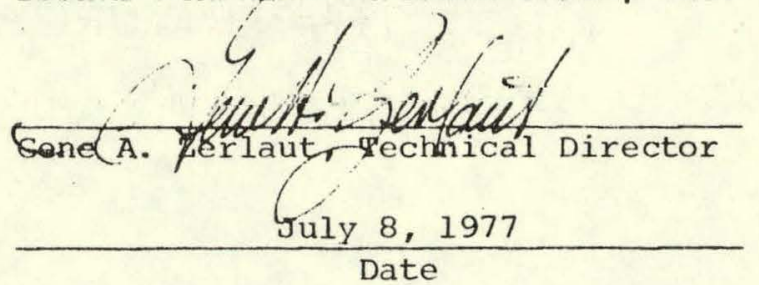

DSET, Inc. uses reasonable diligence in the manner of performing the services required but no warranties are given and none may be implied directly or indirectly relating to DSET services or facilities or to the tests or calibrations by DSET upon Buyer's equipment. In no event shall DSET be liable for collateral, special or consequential damage. 

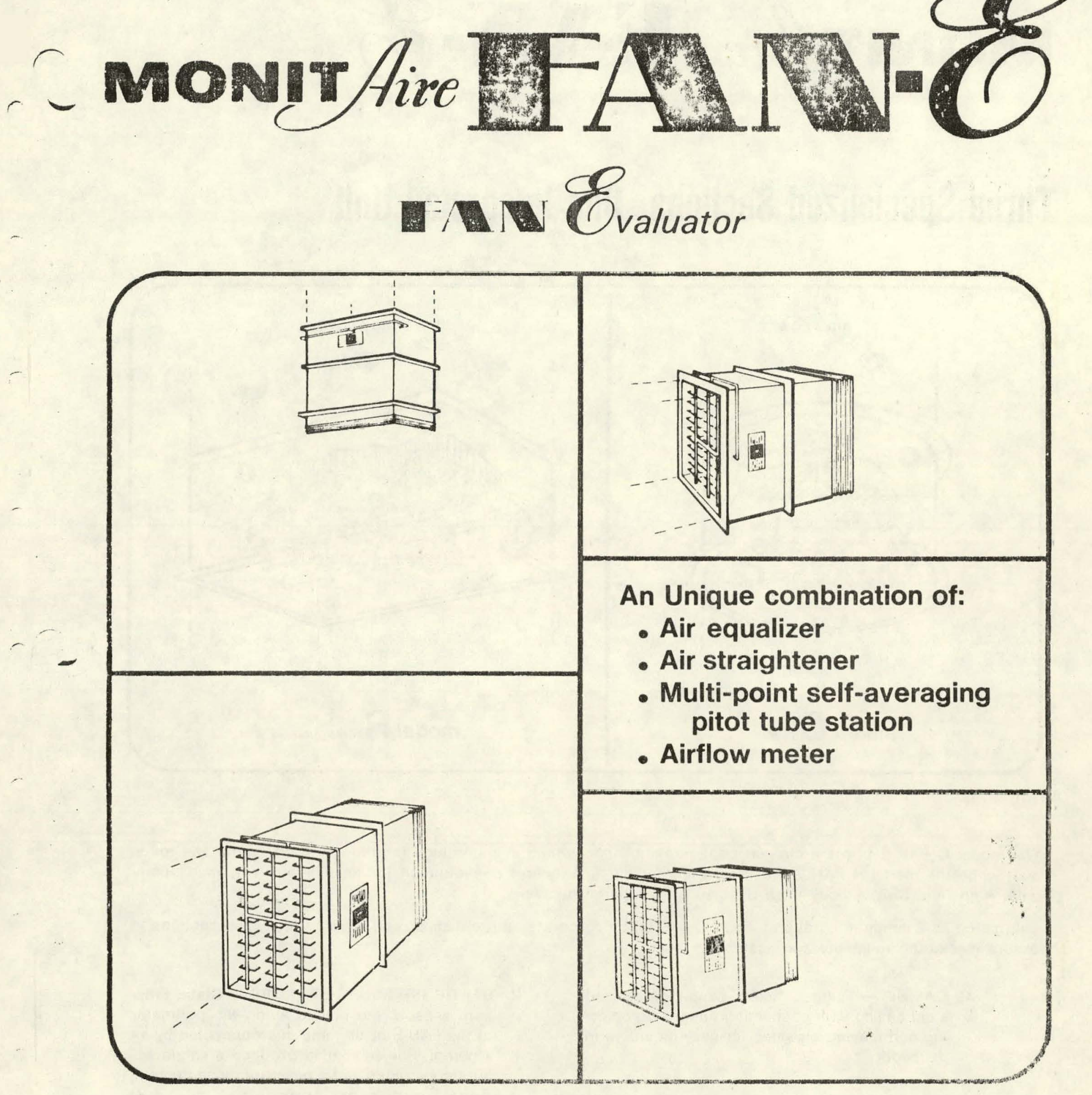

\section{For accurate Measurewsent and Control of Fan Air Handlling Capacity}




\section{MONIT/ire WIN- $\mathscr{E}$}

\section{Three Specialized Sections - One Integrated Unit}

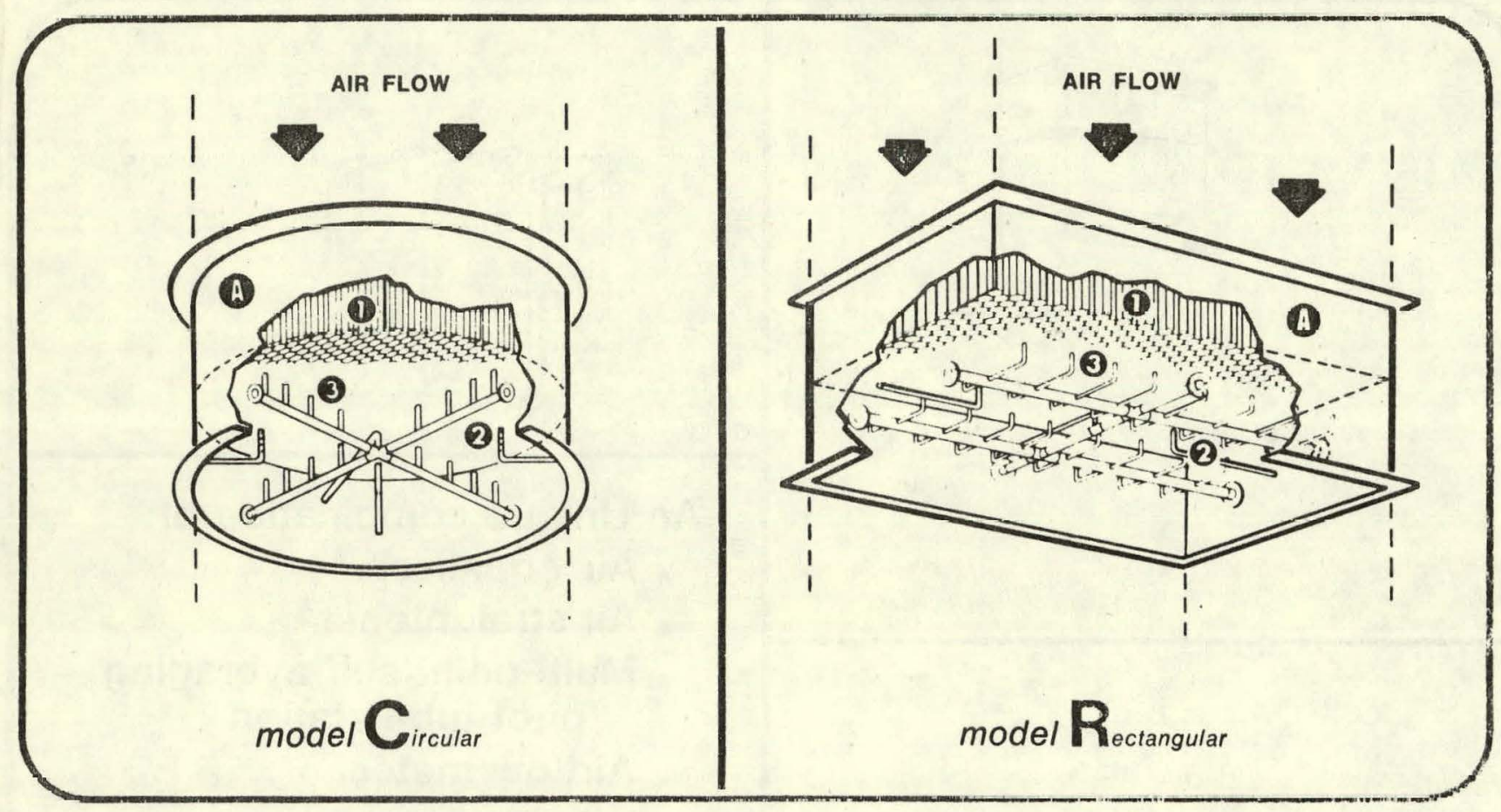

The model C FAN-E offers a circular configuration for mounting in round high (and low) velocity spiral and round duct while the model R FAN-E provides a rectangular (or square) configuration for installation in normal rectangular high (and low) velocity main duct or fan discharge ductwork.

Fabricated as a single integral unit, each FAN-E unit incorporates three distinct and highly specialized sections to assure measuring reliability and accuracy.

A. CASING - Rugged heavy gauge galvanized steel casing with connecting flanges on entering and leaving air sides for casy mounting in ductwork.

1. AIR EQUALIZER AND STRAIGHTENER - EXpanded aluminum honeycomb with close parallel cell orientation and extended depth configuration has the capacity to equalize the velocity profile of the entering air while eliminating turbulent rotational air flow by directionalizing the air into laminar flow.
2. STATIC PRESSURE SENSORS - Static pressure sensors are placed along the perimeter of the FAN-E casing and interconnected by an external tube header to produce a single accurate averaged static pressure measurement.

3. TOTAL PRESSURE SENSORS - The total pressure sensing section is comprised of a network of interconnected tube headers, each with a series of multiple total pressure sensors with sensor openings directed into the straightened air flow. Total pressure sensors are positioned so that each sensing point represents an equal measuring area. 


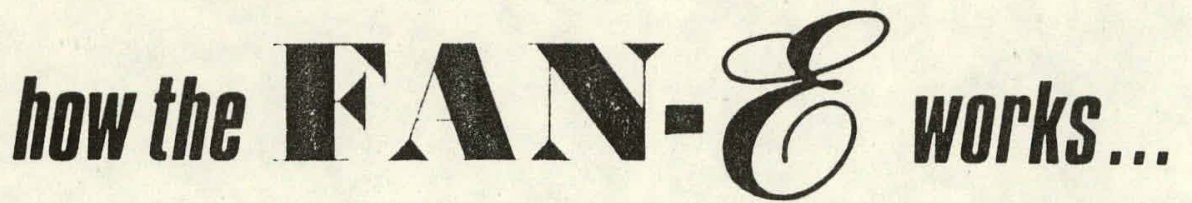

The FAN-E, utilizing old established air flow principles in a new application concept. combines in a single unit devices to condition or "treall" the ail prior to it:s ar:fual me:sture: ment. How it works is briefly outlined below.

Fans (blowers, etc.) move air by centrifugal force resulting in the air near the fan discharge being "piled-up" or stratified (Figure 1). It is the function of the combination air equalizing and straightening section of the FAN-E unit to simultaneously reduce the sharp variance in air velocity projections present in the stratified air flow while eliminating all turbulent or rotating air flow. The individual wall surfaces of each of the long parallel tubes comprising this unique honeycomb section produces a separate wall friction or drag effect on the stream of air passing through that tube the amount of this resistance to flow varying with the square of the air velocity. The result is a sharp reduction in the variances in the velocity profile of the air flow leaving the section. Simultaneously with the passage through the long honeycomb tubes, all air rotation (turbulence) is eliminated and uniform laminar air flow is delivered to the sensor sections. (Figure 2.) The air flow has now been fully processed for accurate measurement

The sensor sections function on the principle of a pitot tube (with separated static and total manifolds). With assured laminar air flow into the sensor sections, the multi-point total and static sensors (up to 100 individual sensors for the largest FAN-E unit) can accurately measure the total and static pressures in the unit and average each by means of interconnecting manifolds to a single representative value (an application of Bernoulli's Equation and Tchebycheff's calculus for averaging of measurement). By transmission of these values (total and static pressure) by tubing to an air flow meter. (differential gauge), the velocity pressure through the FAN-E unit can be accurately read or recorded By application of controls and relays, the FAN-E can control fan capacity at constant volume or programmed volume changes.
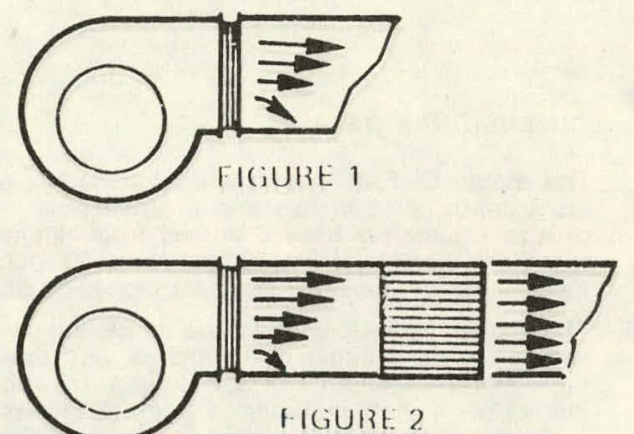

FIGUIRE 2 WAN-O Applications:

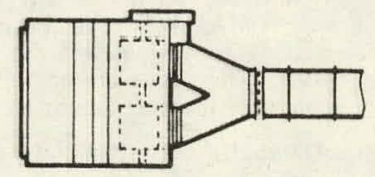

Air Handling Unit

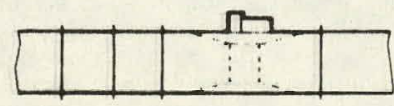

Vane-axial Fan (Exhaust)

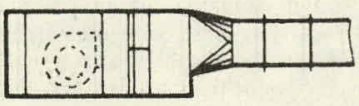

High Pressure Fan

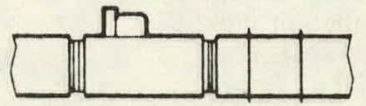

Vane-axial Fan (Supply)

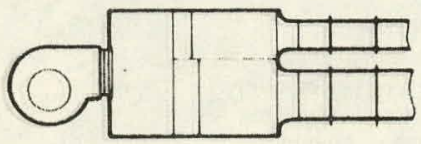

Dual Duct High Pressure

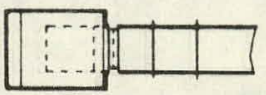

Fan-coil Unit

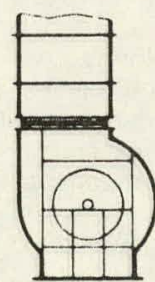

Supply Fan

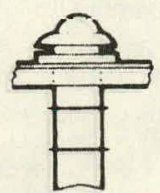

Roof Power Exhaust

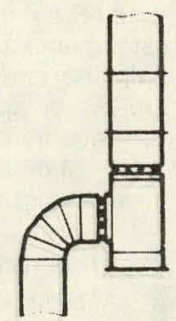

Utility Fan

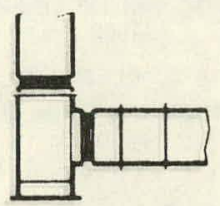

Exhaust Fan 


\section{RESISTANCE TO AIR FLOW}

A physical structure placed across the flow of air in a duct will impede the flow; the magnitude of which, normally referred to as resistance to air flow, is a function of the size and shape of the structure and the quantity of air passing through it,

The MONIT-Aire FAN-E unit was designed to function while producing a minimum of resistance to air flow. The unique honeycomb air equalizing and straightening section has a free area of $96.6 \%$ while the total and static pressure sensors usually represent an area equivalent of less than $1.2 \%$ of the unit's total area.

The unique non-restrictive characteristics of the FAN-E units are seen in the Resistance to Air flow versus Unit Velocity graph on the right.
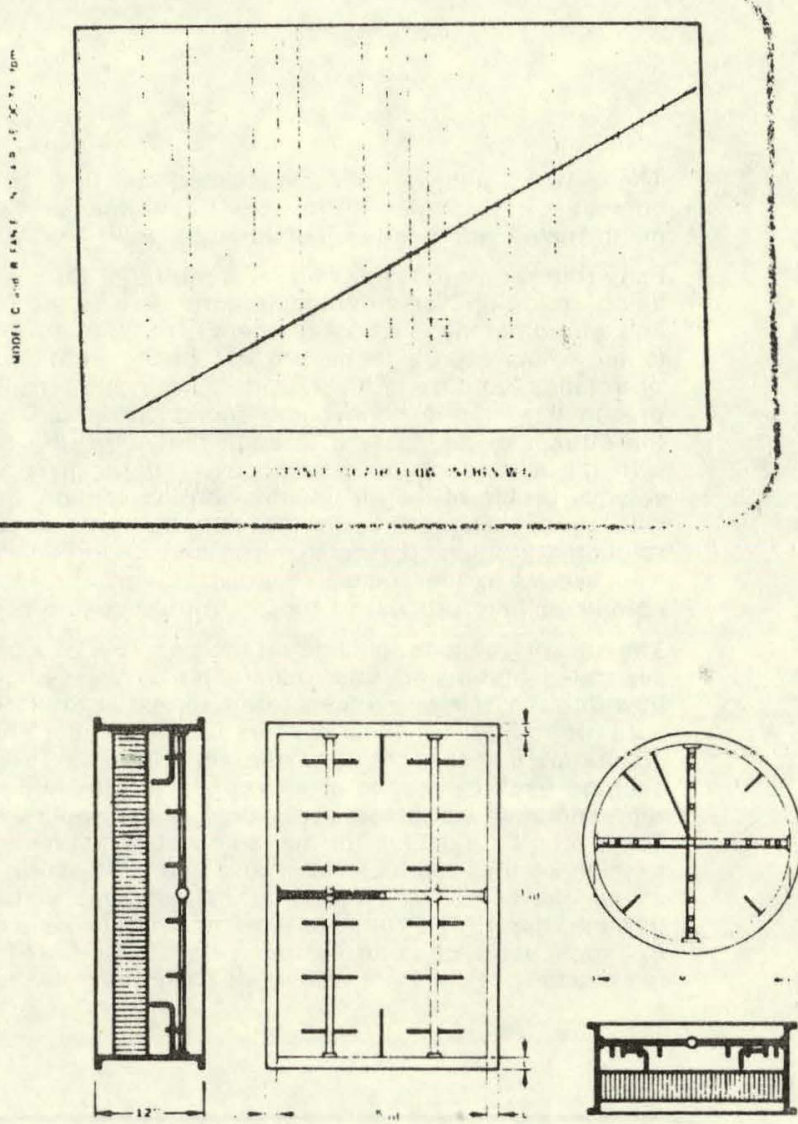

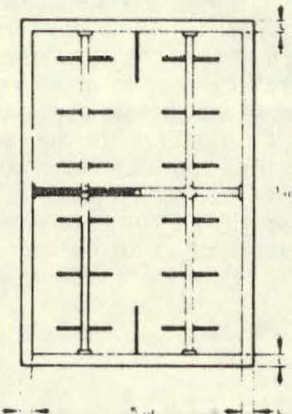

- -

The model C, FAN-E units are furnished in casings with a constant depth of 12 inches and are available in 2 inch increments of size (diameter) from 6 inches to 30 inches; in 6 inch increments of diameter from 30 inches to 60 inches; and in 12 inch increments of diameter from 60 inches to 96 inches.

The model R, FAN-E units are furnished in 1089 casing sizes, with a constant depth of 12 inches, and are available in 2 inch increments of width $(\mathrm{J})$ and height $(\mathrm{K})$ from 4 inches to 36 inches; in 4 inch increments from 36 inches to 60 inches; and in 6 inch increments from 60 inches to 120 inches.

FAN-E units are only available with 90 degree connecting flanges on the air entering and leaving sides, varying from 1" to 2", depending upon unit size.

model Rectangular

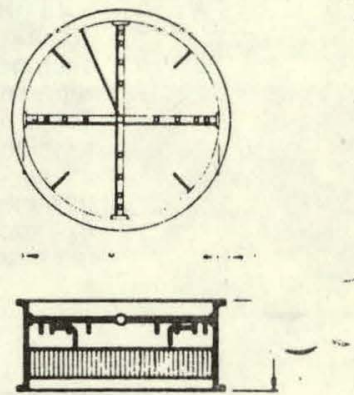

model Circular

\section{AIR FLOW METERING SYSTEMS}

Dealing in directly measurable values of total pressure. static pressure and unit area ... while being devoid of any special laboratory developed correction factors, conversion tables. or calibration curves ... the air flow metering arrangements that can be applied to FAN-E units and D.A.M.D. stations are essentially unlimited. Shown below are several of the more commonly applied systems.

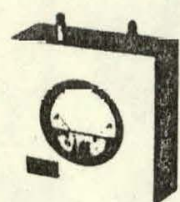

\section{SIATIONARY (DRY) METFR}

A diaphragm actuated differential pressure gauge mounted on a metal pancl with calibrated viale ti permit direct reading of unit velocity in feet per minute. or where specified, in unit or station air flow volume in cubic feet per minute. For continuous monitoring of fan or duct capacity with effective range of 800 to $4000 \mathrm{fpm}$.

CENTRAL READOUT OR CONIROL PANEL

The pressure transmitting tubes from multiple FAN.E or D.A.M.D. installations are brought to a central panel capable of individual FAN E unit or D.A.M.D. station readout with a single air flow meter. The panel con sists of a diaphragm actuated differential pressure gauge flush mounted on a metal control panel with a series of push button valves, all with station designa. tions. To read the velocity at any remotely located FAN E unil or D.A.M.D. station, the indicated unit or station buttons are pressed and the velocity is regis tered on the meter. There aie ilu lecimical limitations

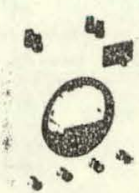
to the number of readout stations on a single panel.

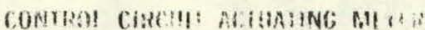

A diaphragm actuated differential pressure gauge with dual photo-cell electronic amplifier and slave relay circuit. Meter scale calibrated to permit direct reading of FAN.F or D.A.M.D. velocity in feet per minute or whliese specified, ill unil ur slation air flow volume in cubic feet per minute. For use where high and/or low limit controls on air flow are required for actuating alarms, warning lights, damper motors, etc.

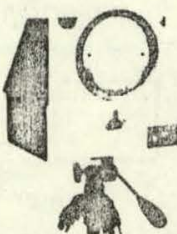

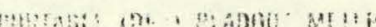

A diaphragm actuated differential gauge mounted in a mictal carrying case with detachable leveling tripud stand Meter scale calibrated to permit the direct read. ing of the velocities in feet per minute of multiple FAN.E unit or D.A.M.D. station installations. Meter complete with on-off air meter switch and quick. connect fittings. 


\section{Automatic Air Flow Control}

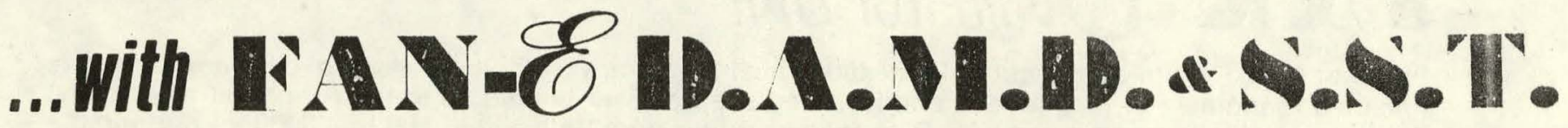

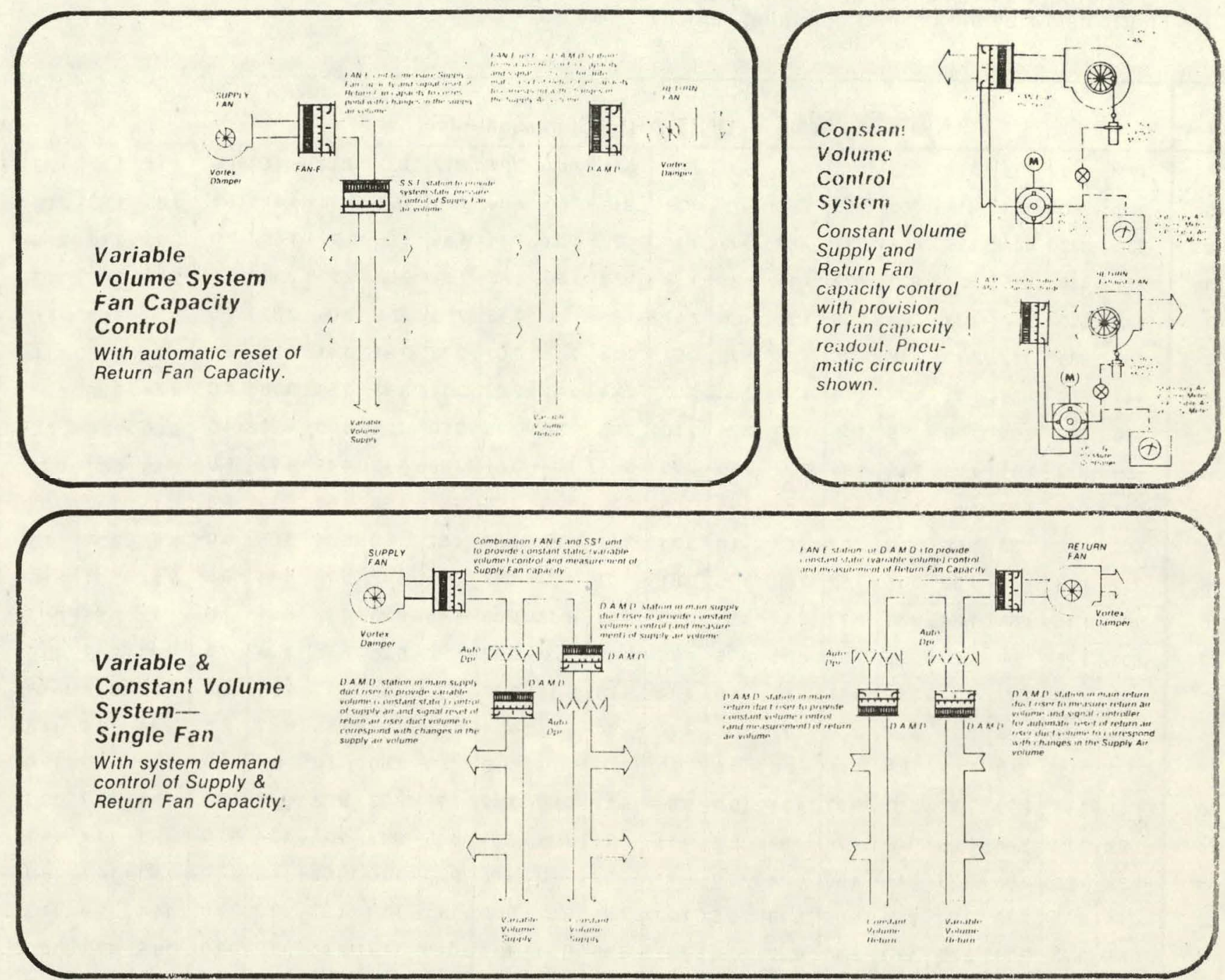

Variable \&

Constant Volume

System-

Single Fan

With automatic reset of

return air volume at

individual floors.

With system demand

control of Supply \&

Return Fan Capacity.
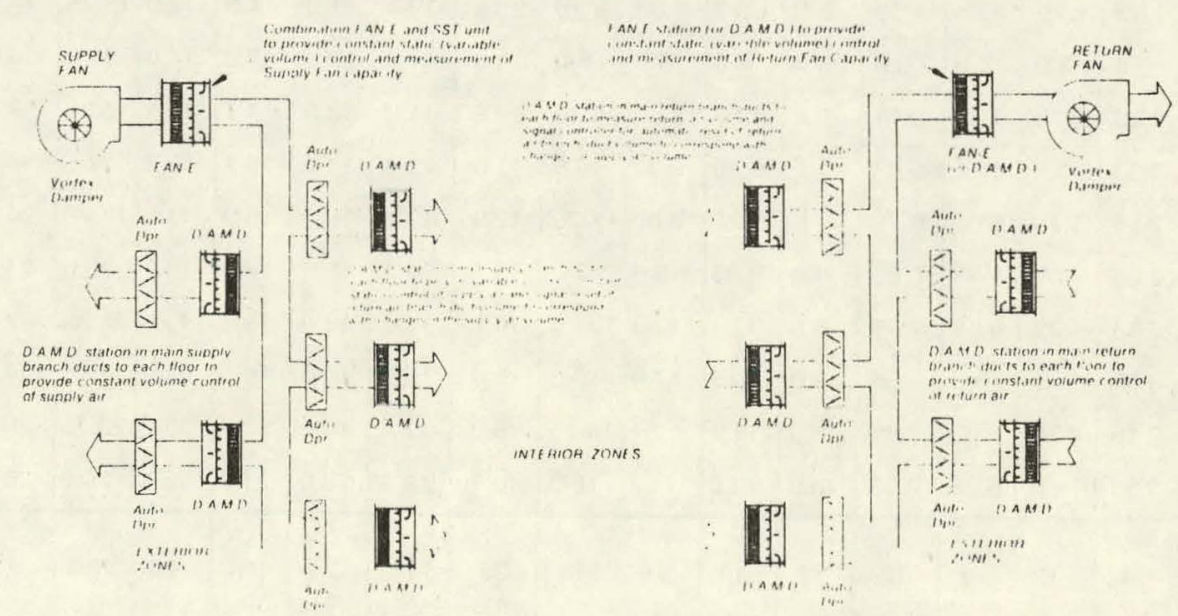

DA A $D$ S stateon in man selurn

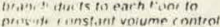

1.

Ain. 


\section{- Ovaluator Unit}

Pre!ace: FAN-E units can accurately measure air flow at any velocity. Pressure differential meters (inclined manometers, magnehelic gauges, etc.) are however limited as to their range of readability. For this reason we recommend FAN-E units be sized for operation within 800 to 4,000 feet per minute.

Unit area (sq. ft.) $x$ tesirer operating velocity $(f \mathrm{pm})=$ Unit Capacity (CFt,

To determine the CFM Capacity of a specific size FAN-E unit, multiply the Unit Area listed in the charts below by the desired operating velocity.

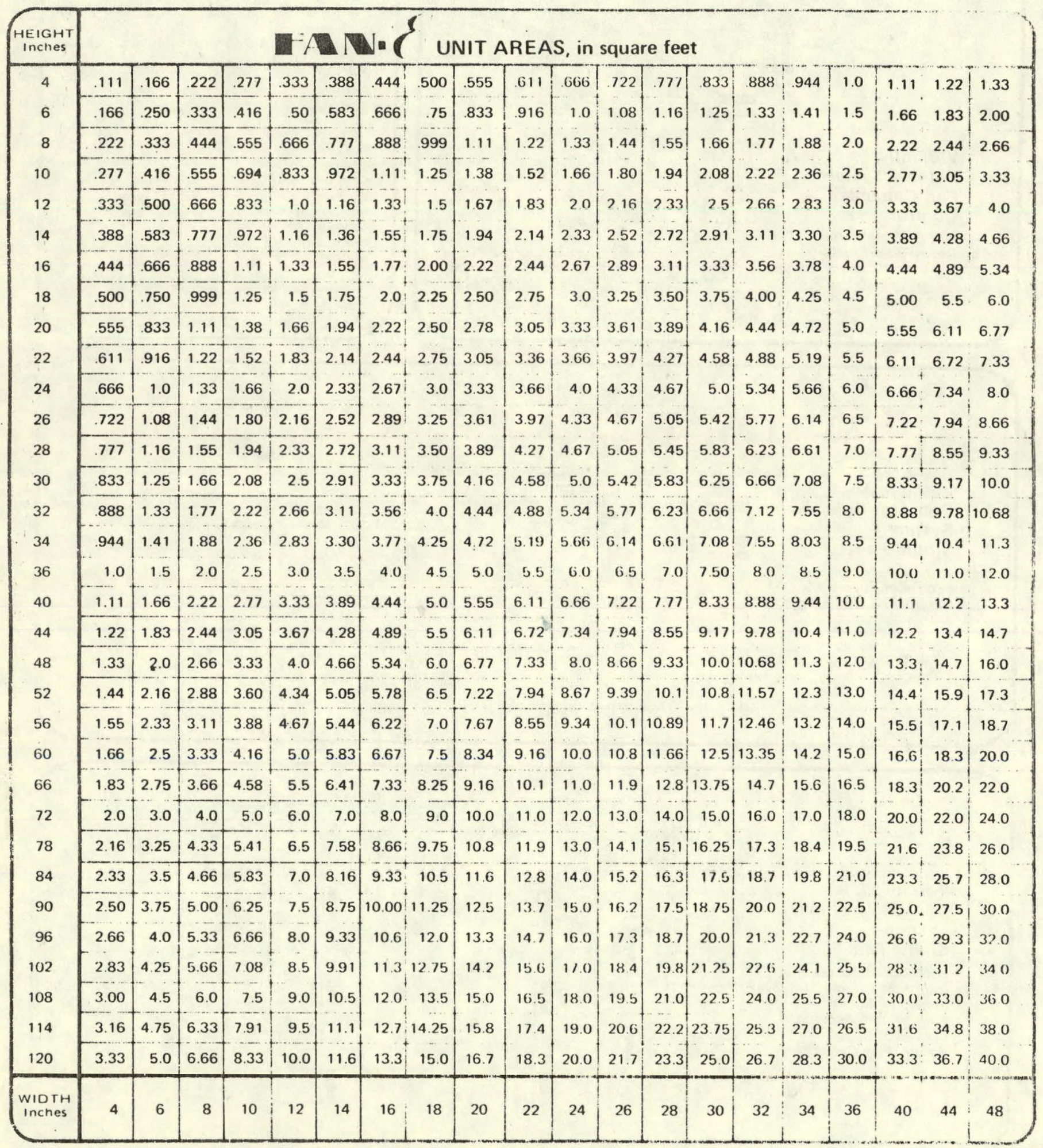




\section{Areas and Capacity Formulations}

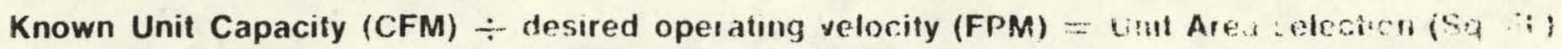

If the CFM Capacity of the fan is known, divide this value by the desired operating velocity to determine the unit area. Entering in the charts below, list (for final selection) those FAN-E unit sizes approximating the unit area figure obtained above.

Known Unit Capacity (CFM) - Unit Aica (Sq. Ft.) -: Unit operating slocity (pm)

If the CFM Capacity of the fan and the required FAN-E unit size is known, the operating velocity can be determined by dividing the CFM by the unit area listed in the charts below.

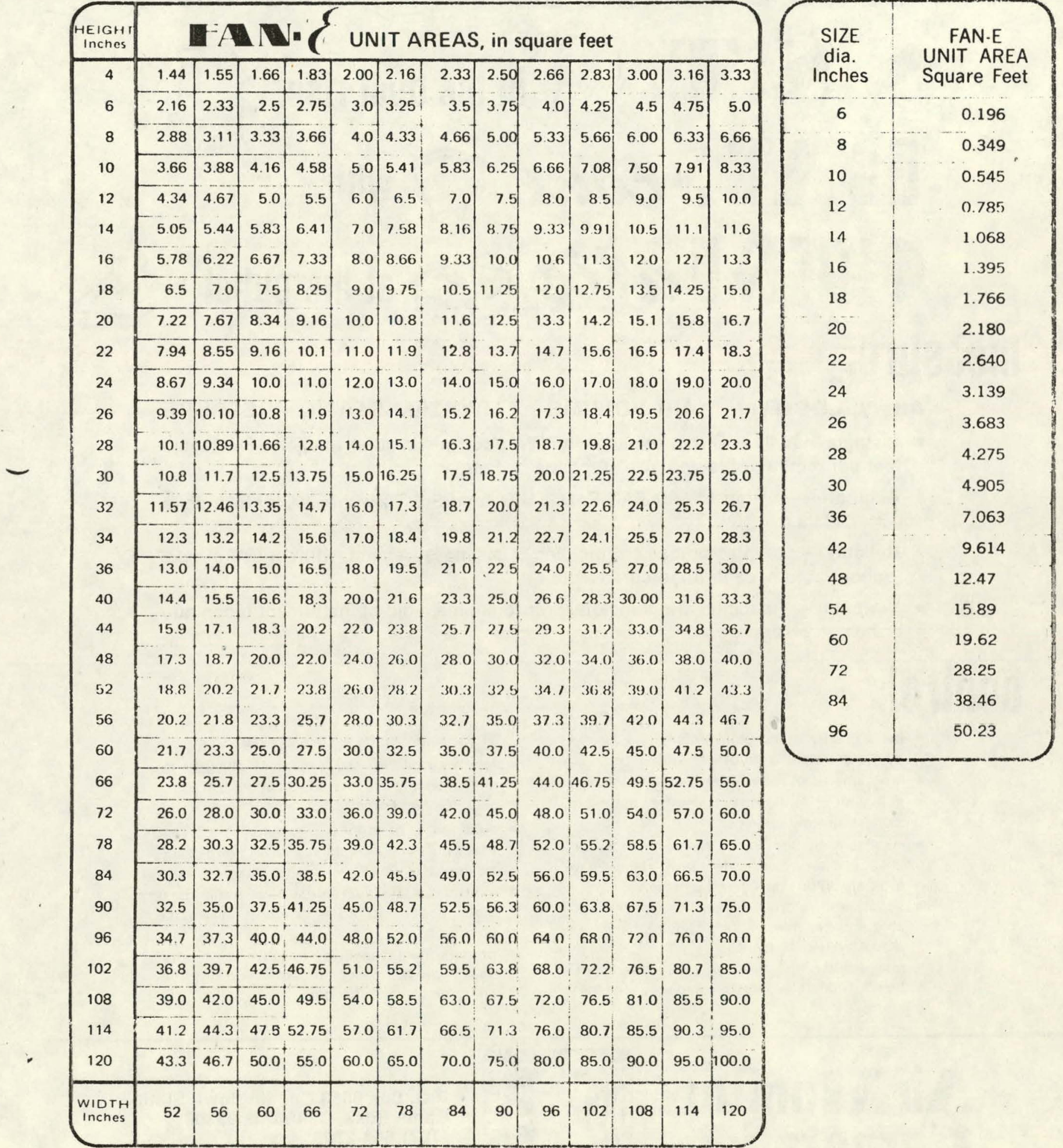

FIGURE $1.3 .1(n)$ 


\section{:}
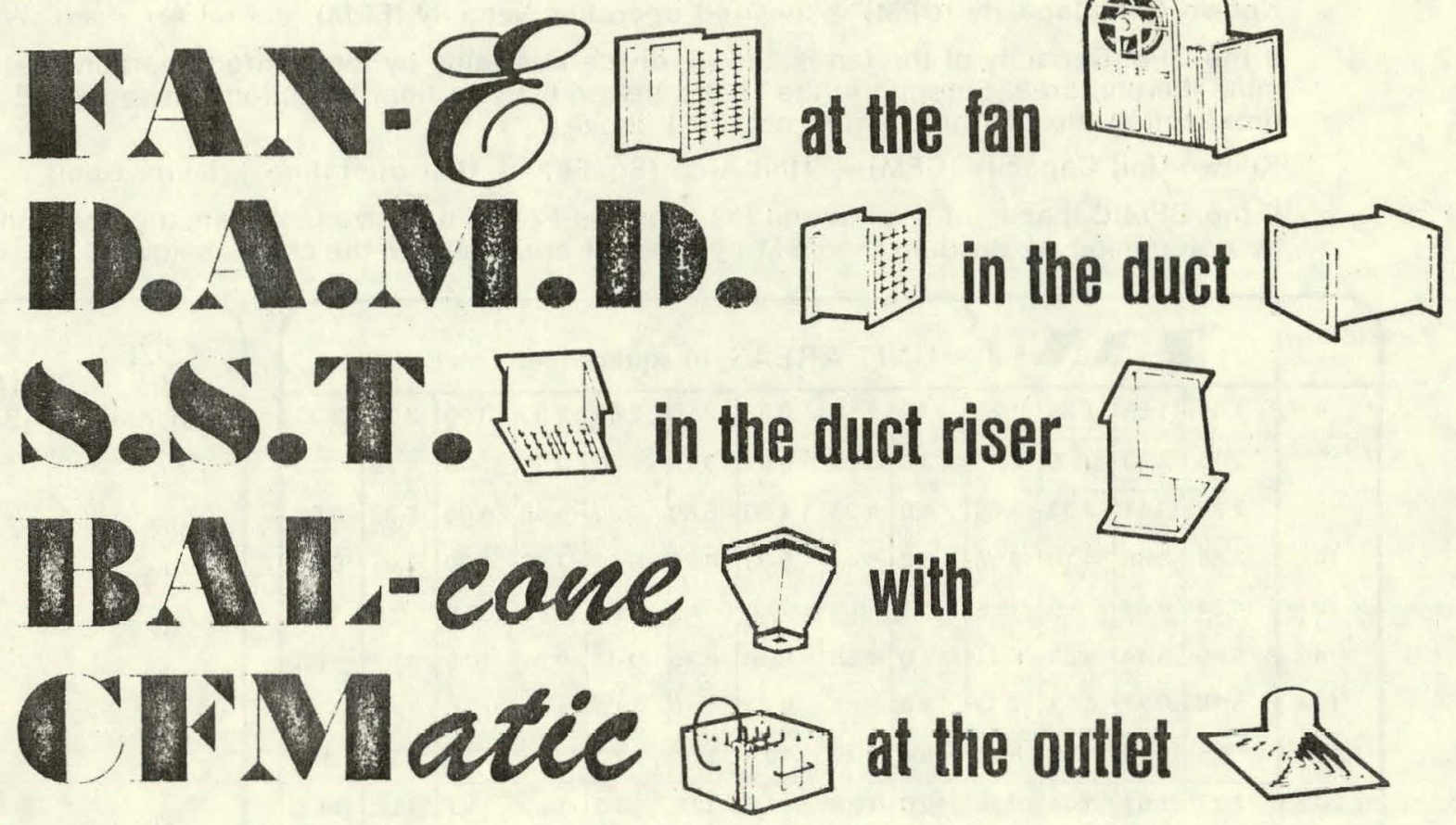

\section{measure:}

\section{AIR VELOCITY . . AIR VOLUME ... SYSTEM STATIC PRESSURE}

- Instantaneously - Direct readings in FPM (feet per minute) and/or CFM (cubic feet per minute) obtained in 10 seconds or less.

- Accurately - within $1 \%$ for FAN-E, D.A.M.D., and S.S.T.; within $3 \%$ for BAL-cone with CFMatic.

- Reliably - operates on basic principles of air measurement, without use of correction factors, calibration curves, etc.

- Verifiably-Readings are completely reproducible, void of instrument technique or human error.

\section{control:}

- fan capacity at constant volume regardless of system static changes or variations.

- programmed or manual reset of fan capacity.

a actuation of Audio or Visual safety alarms in critical air flow systems.

- maximum air filter replacement cycle based on actual air volume, decrease, rather than arbitrary filter resistance increase.

- supply and return fan capacities under variable and constant volume systems based on actual system demand.

- rescheduling and reset of return fan capacities to match supply fan capacity changcs in variable volume system operation.

- return air duct or space quantity changes to match supply air quantity changes (in variable volume system).

* continuous or periodic monitoring of fan (duct, or outlet) capacities at a central control panel.

- control of fan, duct or system static pressures under variable or constant volume operation.

- predetermined positive, negative or neutral space pressurization regardless of system slatic or volume changes.
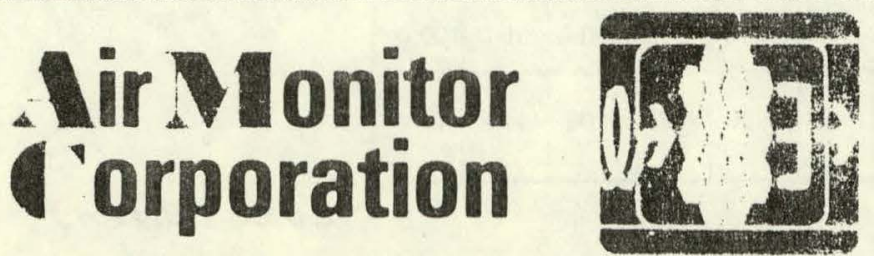

P.O. Box 6358 Coddingtown Station Santa Rosa, California 95406

(707) 544-2706 


\section{Air Monitor Corporation}

P. O. BOX 6358 CODDINGTOWN STATION

SANTA ROSA, CALIFORNIA 95406

AREA CODE (707) 544-2706

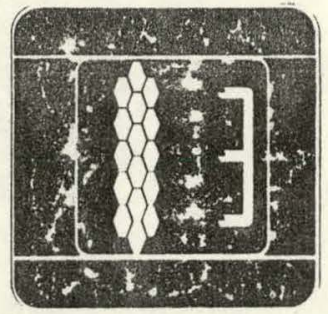

June 28, 1977

Mr. Ken Mohn

Owens-I11 inois

200 North Westwood

Toledo, $\mathrm{OH} 43666$

Subject: Special FAN-E supplied on wo\#1552

Dear Mr. Mohn:

The FAN-E delivered to you has an accuracy of $\pm 1 \%$ in the range of 300 to 600 SCFM providing that the FAN-E is installed correctly. This special FAN-E requires twice the standard installation distance. Enclosed is a sheet of installation distances for standard units.

We recommend that your arrangement should be fan, 2 diameters of duct; screen unit, 4 diameters of duct; FAN-E, 4 diameters of duct; and screen mounted on the entrance to the plenium. For best results, we recommend that lab work should be done on the possibility of eliminating the plenium, since it may effect accuracy.

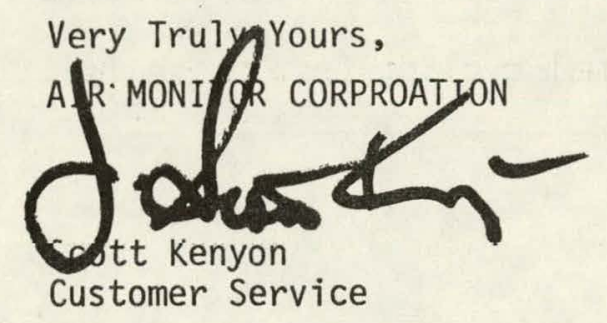

Enclosures: FAN-E brochure Installation Guide

$\mathrm{SK} / \mathrm{jda}$

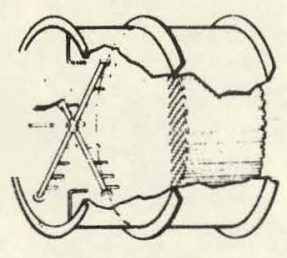

B
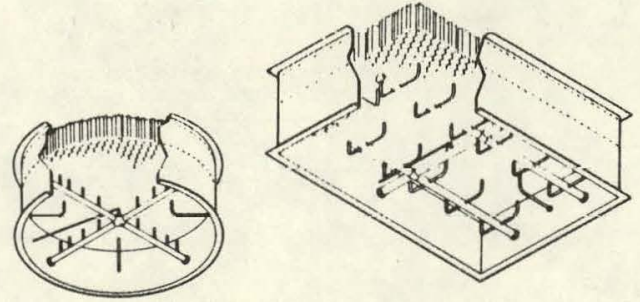

Duct A irM Monitor Device

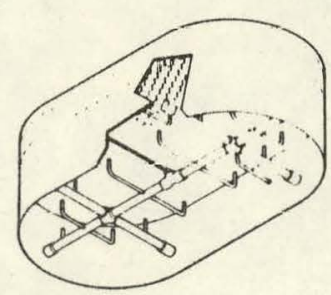

33

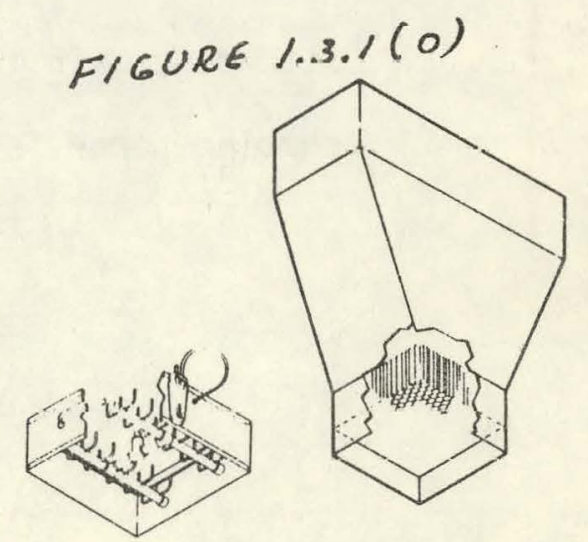

- Matic 


\subsection{System Design Conditions.}

The Model SEC-601 air collector was ronf mounted south facing at a $45^{\circ}$ tilt. Ducting, instrumentation, heat exchanger and air fan were installed. The duct between the flow meter and the heat exchanger was detached in order to provide access for smoke ingestion into the system. The ducting loading from the collector was blccked. The variable speed air fan was adjusted to provide 1.5 inches, w.g., atove ambient in the collector manifold. A smoke bomb was activated at the inlet to the air fan. No evidence of collector or system leakage could be detected.

The system hook up was completed and all ducting and components insulated. A series of air mass flow versus collector pressure drop tests was completed. The test system schematic and the test data is contained in Figure 2.1(a). A plot of the data and the equation relating air mass flow to pressure drop is contained in Figure 2.1(b). The tests conducted under Section 5.2, temperature and pressure resistance are also applicatie to the subject Section 2.1. Data from the tilerrial cycling test phase is contained in Figure 2.1(c).

\subsubsection{Equipment Capabilities.}

The design flow rate of the Model SEC-601 collector is approximately 8 Lbs./Hr.Ft. ${ }^{2}$ higher system flow rates may be used with an attendent gain in collector thermal performance. The fan theoretical fumping power is related to flow ard pressure drop by the expression: 


$$
\begin{aligned}
\mathrm{HF}= & 157.5 \times 10^{-6} \mathrm{p} \text { (1) } \\
& p=\text { Pressure drop, inches, w.g. } \\
Q & =\text { Total air flow; Ft. } 3 / \mathrm{min} .
\end{aligned}
$$

Using the data of Figure 2.1(a)

$$
\begin{array}{rccccccc}
\Delta P_{C} & .03 & 0.5 & .10 & .15 & .20 & \\
Q & 142 & 184 & 261 & 320 & 369 & \text { CFin } \\
P & .29 & .48 & .95 & 1.35 & 1.75 & \text { in. w.g. } \\
H P_{a} & .0065 & .0139 & .0391 & .068 & .1017 & H P
\end{array}
$$

However, system pressure drop, leakage and fan efficiency will affect the sizing of the fan. Host common electric motors will not survive the high temperatures within the air system ducting; an externally mounted motor with an extension shaft coupling to the air fan is recommended.. The temperature rise due to fan inefficiency is generally recoverable if a suitable heat barrier is employed in the extension shaft and motor. mount. Relatively low fan pumping power is required to move the air through the collector.

\subsubsection{Noise or Erosion-Corrosion.}

During the air mass flow-pressure drop experiments, no sound emanating from the collector tube elements or the manifold could be detected at a system air flow rate up to 369 CFM. The 144 tube ERDA collector manifolds and tube elements. were inspected after 17 months of test operation. Fio evidence of erosion-corrosion could be detected in

(1) Page 14-67?, Marks' Mechanical Engineers Handbook, Sixth Edition, Mćraw Hill. 
any of the vorking components. Some evidence of deterioration of the polyurethane foam insulation was noticed where the insulation was directly exposed to high temperature air flow. Shere the insulation material was protected, no visitle sign of deterioration of the insulation was detected. The Model SEC-601 collector design protects the polyurethane foam insulation from contact with high temperature air. Following completion of the 100 cycles of thermal cycling at exit air temperature of $325^{\circ} \mathrm{F}$, the manifold was visually inspected, No sign of deterioration of materials or components could be detected.

\subsubsection{Operating Conditions.}

The components of the Model SEC-601 collector have been tested in excess of the pressure and temperature ranges expected in actual service without damage or loss in pressure that could impair their intended functions. Over pressure and high temperature thermal cycling test data of Figure 2.1(c) is provided as primary evidence along with other test data as contained principally in Section 5.2.

\subsubsection{Fluid Flow in Collectors.}

The 144 tube ERDA collector was highly instrumented with thermocouples to measure the temperature rise in a large number of tube pairs in many areas of the array. Each tube pair of the east half of . the lower manifold was instrumented with thermocouples. A typical set of data is as follows:

$$
\begin{aligned}
& \begin{array}{llllllllllllllllll}
36 & 31 & 31 & 31 & 31 & 36 & 37 & 35 & 37 & 40 & 40 & 45 & 40 & 41 & 41 & 40 & 41 & 45^{\circ} \mathrm{F}
\end{array} \\
& 9619093 \quad 101 \% 101 \quad 10595112108108115103 \quad 11310294 \quad 10510293^{\circ} \mathrm{F} \\
& \text { Center-Air Inlet-Outlet }
\end{aligned}
$$


The good correlation of temperature rise is evidence of excellent flow distribution in each of the collector tube elements at the design air flow: rate. At about twice the design flow rate, the temperature rise data was:

33. $30 \begin{array}{llllllllllllllll}30 & 30 & 30 & 34 & 35 & 32 & 35 & 37 & 38 & 41 & 32 & 38 & 38 & 37 & 38 & 40^{\circ} \mathrm{F}\end{array}$

$8991919292949510410210010710211096100999991^{\circ} \mathrm{F}$ Flow distribution remains excellent at the higher flow rates.

Comparative analysis of the ERDA air manifold and the Model SEC601 air manifold indicate similarity of flow cross section and flow rates. The experimentally derived flow-pressure drop relationships for the two collectors are:

$$
\text { ERDA } \quad \begin{aligned}
\triangle P & =\frac{C F M}{27} 1.84 \quad \text { in. W.g. } \\
\text { CFM } & =\text { Volume Flow Fer Tube Pair, Ft. } 3 / \text { min. } \\
\triangle P & =\text { Collector Pressure Drop, inches, w.g: }
\end{aligned}
$$

Model SEC-601

$$
\Delta P=\frac{\text { CFM } 1.92}{10.5} .
$$

CFM - Volunine Flow per Tute, Ft. $3 / \mathrm{min}$.

$$
\Delta P=\text { Collector Pressure Drop, inches, w.g. }
$$

The essentially identical exponent for flow rate suggests that the collector pressure drop is controlled by the flow in the tube elements. The difference in the constant is due to the difference in path length of the two tubes in series versus all tubes in parallel. Leakage flow 
in the ERDA collector also contributes to the larger value of the constant. Since flow distribution is controlled by the pressure drop in the tube elements rather than in the manifold, it can be implied that satisfactory flow distribution obtains in the Model SEC-601 collector by similarity. The flow distribution between modules of a large array is a systems design parameter. A variation in flor! rate module to module of $\pm 25 \%$ will have little impact on overall system performance because of the very low loss coefficient characteristic of the collector.

2.1.7 Pressure Drops.

The air flon:-pressure drop relationship of the Model SEC-EOI collector is contained in the data of Figure $2.1(x)$ and the curve and equation of Figure 2.1(b).

Review of items $2.1,2.1 .1,2.1 .2,2.1 .3,2.1 .4,2.1 .7$ successfully completed.
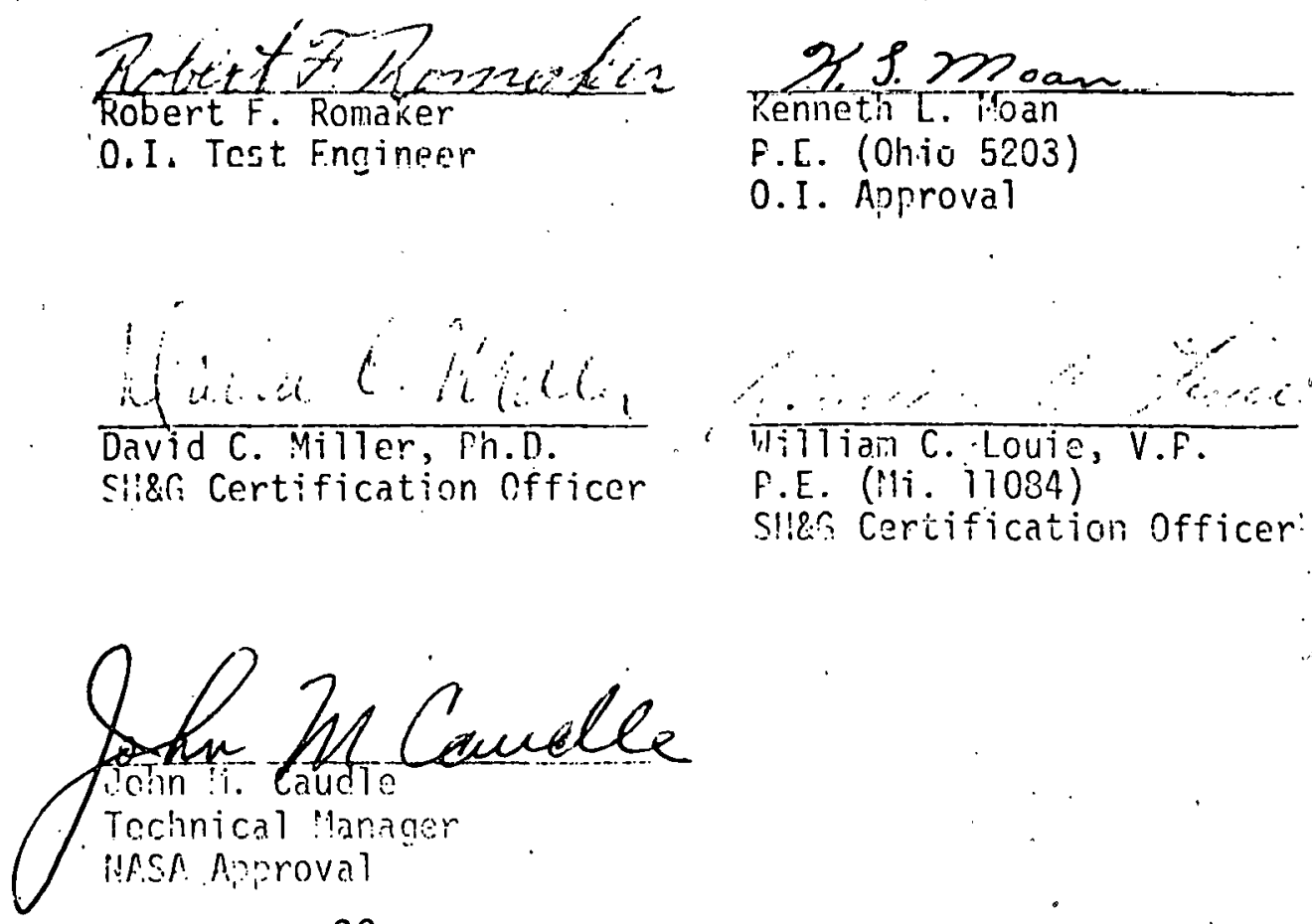

38 
MODEL SEC GOI COLLECTOR

PRESSURE DROP VS AIP FLOW RAYL

NUMBER 3 MANIFOLD

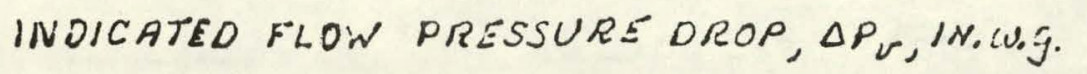

COLLECTOR PRESSURE DAOP, $\triangle P_{C}, I N . w . g$.

AIR TEMPERATURE, OF

AIR MASS FLOW, $\dot{m}_{a}$, LBS. IHR.FT. ${ }^{2}$

AIR VOLUME FLOW, $\dot{m}_{a}$ SCFM/TUBE

\begin{tabular}{|c|c|c|c|c|}
.03 & .05 & .10 & .15 & .20 \\
.29 & .48 & .95 & 1.35 & 1.75 \\
115 & 120 & 126 & 128 & 132 \\
7.01 & 9.01 & 12.67 & 15.49 & 7.83 \\
1.80 & 2.32 & 3.26 & 4.02 & 4.59
\end{tabular}

$\dot{m}_{a}=4005 \mathrm{~A} \sqrt{\Delta P_{L}} \times \sqrt{\frac{530}{T_{A 1 R}+460}} \times .075$ LBS. /MIN.

$$
\begin{gathered}
A=\frac{36 \pi}{4 \times 144}=.196 F T_{0}^{2} \\
A_{C O L L E C T O R}=84 F T^{2} \\
\dot{m}_{a}=42.19 \sqrt{\frac{\Delta P_{L} \times 530}{T_{A R}+460}} \quad \text { LBS./HR.FT. } \\
\dot{m}_{a}=10.85 \sqrt{\frac{\Delta P_{L} \times 530}{T_{A I R}+460}} \mathrm{SCFM/TIBE}(72 \text { TUBES/RODOLE })
\end{gathered}
$$

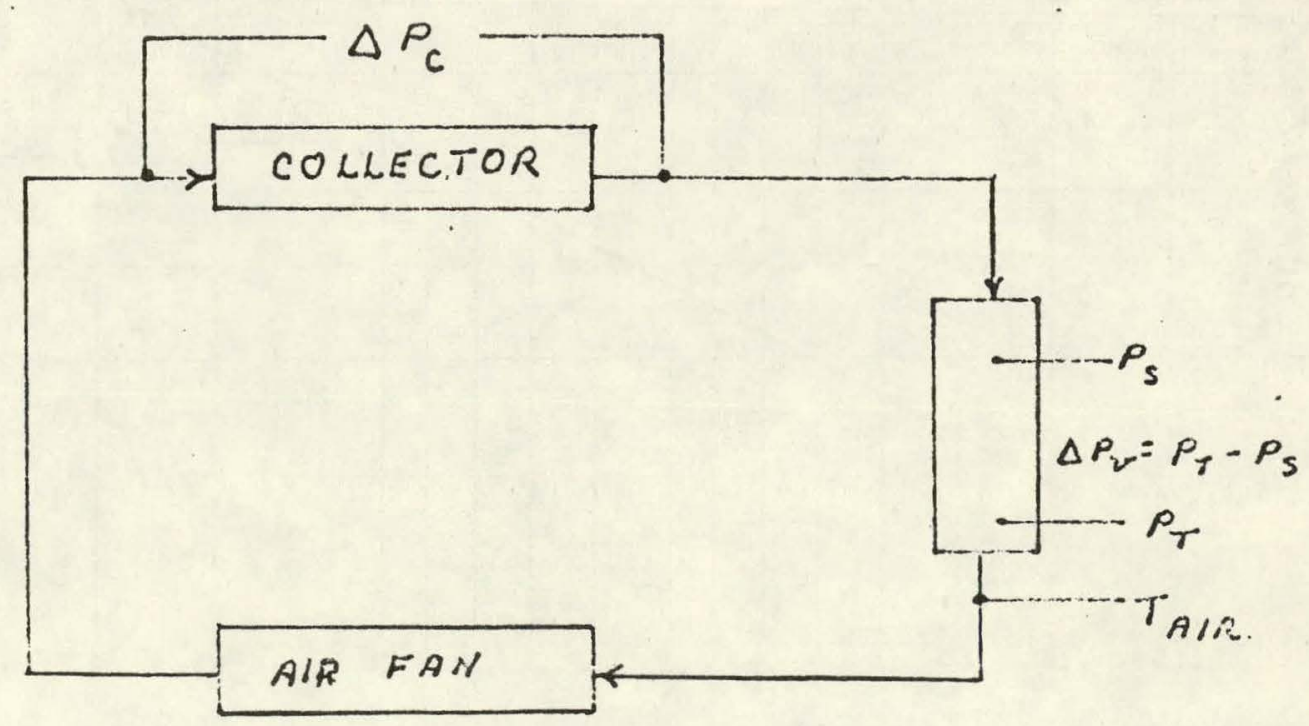

TEST SYSTEM SCHENATIC

FIGURE $2.1(a)$ 


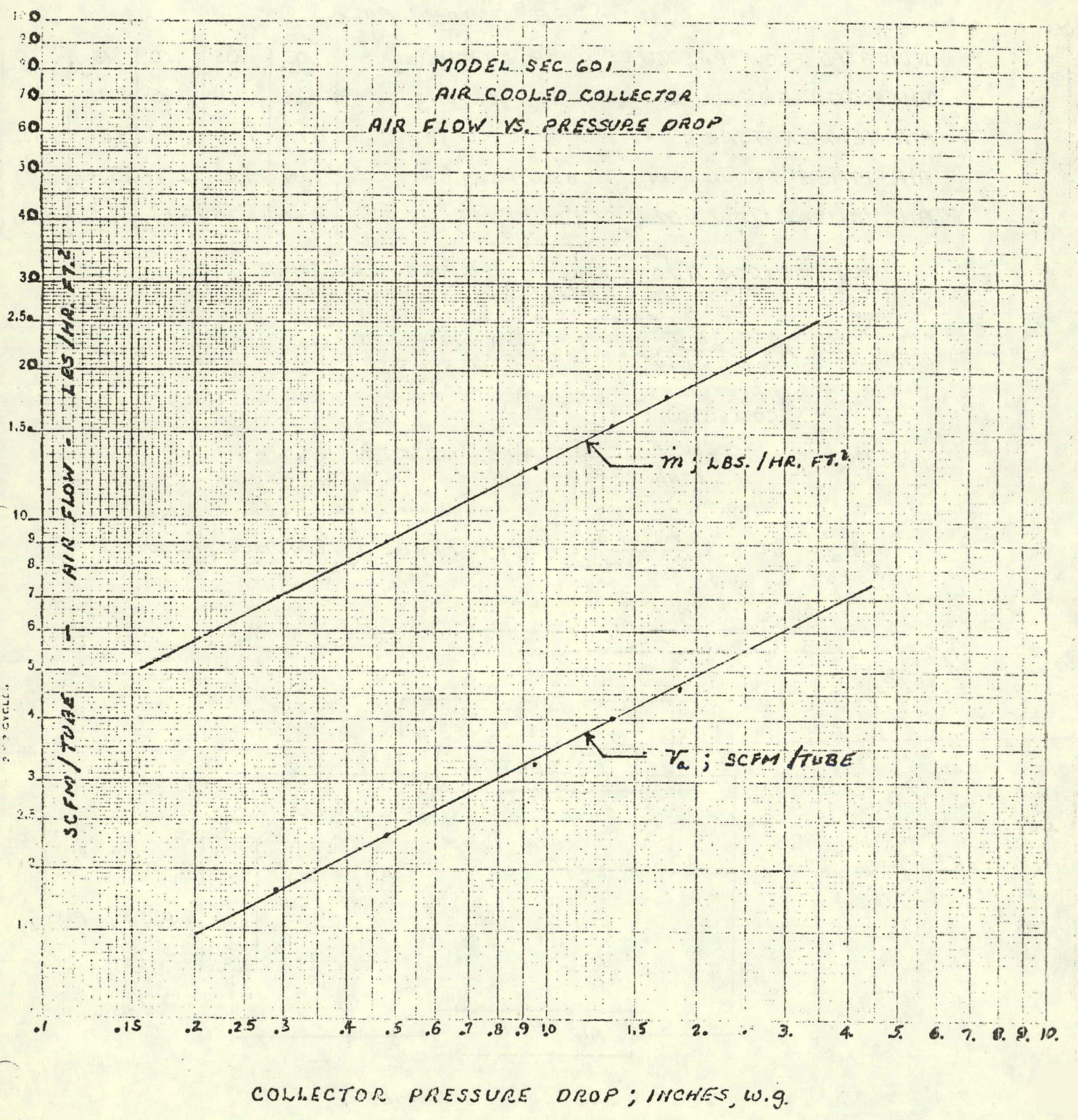




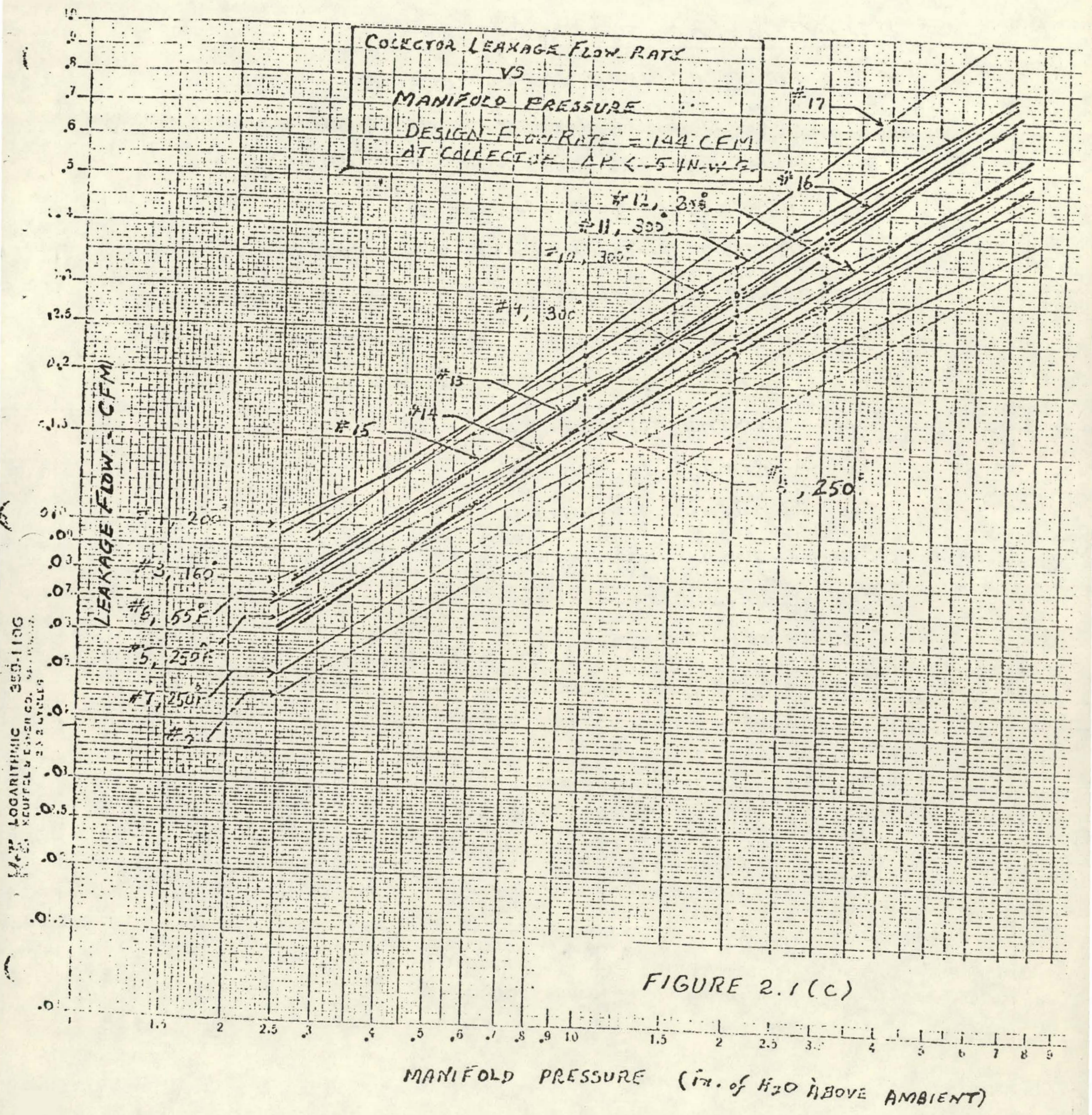


DEFINITION OF TEST NUMBERS

* 2. FIRST CALBRATED LEAMAGE FLOW TEST

" 3 ONE CYCLE TO $160^{\circ}$ M MAX. AIR TEMP.

"4 ONE cYClE TO $200^{\circ}$ maX. AIR TEMP.

"5 ONE CYCLE TO $250^{\circ}$ F MAX. AIR TEMP.

*6 rePEAT aMBIENT aIR tEMP. LEAKALETEST

"T* 8 REPEAT CYCLES AT $250 \%$ MAX AIR TEMP.

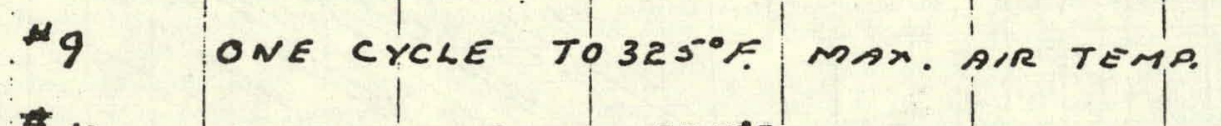

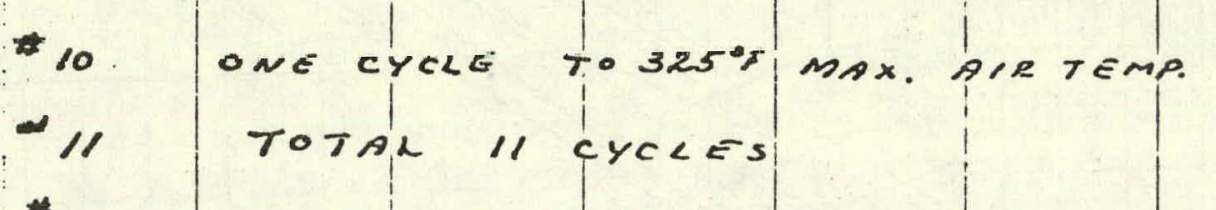

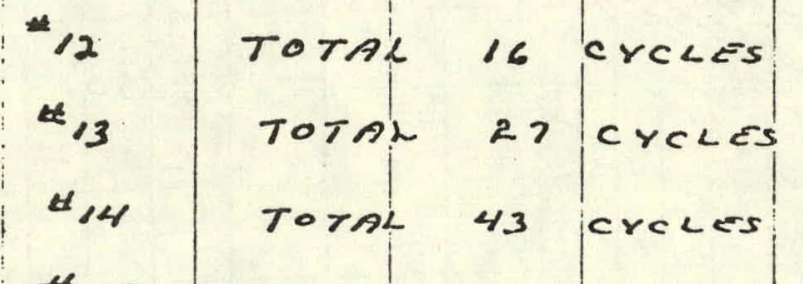

\#is total 5 cycles 


\subsection{Mechanical Stresses.}

\subsubsection{Vibration Stress Levels.}

During the testing described in detail in Section 5.2.4, Leakage, the collector module was critically inspected for any audible evidence of vibration induced in any collector component due coupling with air ducts or fan. No audible sound could be detected. No evidence of vibration of any component of the collector could be detected by thorough inspection of the ERDA 144 tubular air collector. The potential problem of reinforced resonance vibration of the absorber tube was investigated. A collector tube element was instrumented with strain gages as shown in Figure 2.2.(a). No selective coating was applied and the evacuation process eliminated since the bonding agent used for applying the strain gages could not tolerate the bake out temperature.

The collector tube element was mounted on a vibration shake table and excited in the range of 0 to $300 \mathrm{~Hz}$. Two resonant peaks were observed, one at $139 \mathrm{~Hz}$. and one at $214 \mathrm{~Hz}$. Prolonged exposure at these frequencies gave no evidence of damage. A frequency response plot of the tube assembly is shown in Figure 2.2(b). The modulus of elasticity of KG-33 is $9.5 \times 10^{6} \mathrm{lbs} . / \mathrm{in}^{2}$. The maximum detected strain

was 27 micro inch/inch. The resulting maximum stress level is 227 psi, well below the modulus of rupture stress level of an abraded rod of 10,000 psi.

\subsubsection{Vibration from Moving Parts.}

There are no moving parts within the Model SEC-601 collector except air flow. No evidence of flow induced vibration could be 
detected up to air flow rates of $16 \mathrm{lbs} . / \mathrm{Hr} . \mathrm{ft} .^{2}$, twice the design air flow rate. No evidence of coupling of the vibration due to moving parts such as the air fan could be detected.

\subsubsection{Vacuum Relief Protection.}

The installation and maintenance manuals specify that the air fan be located in the inlet ducling to the manifold. This will insure that the manifold will always be at a positive pressure. The manifold was exposed to a positive pressure of 5 inches w.g. repeatedly during the leakage tests of Section 5.2.4 with no evidence of structural stress or induced air leakage of greater than $1 \%$ of design flow rate.

\subsubsection{Thermal Changes.}

The collector was subjected to 100 cycles of thermal stress from ambient temperature to $325^{\circ} \mathrm{F}$. No evidence of degredation of any component or sub-assembly could be detected as demonstrated by no change in the rate of leakage air flow from the collector. See Section 5.2 for substantiating experimental data.

\subsubsection{Flexible Joints.}

Connecting ducting was in place during the thermal cycling tests of Section 5.2. The flexing of the connecting ducting due to air flow and thermal cycling was accommodated by the interface and mounting provisions of the Model SEC-601 collector. 
Review of $i$ tems $2.2,2.2 .1,2.2 .2,2.2 .4,2.2 .5$ and 2.2 .6 successfully completed. Robent R Romaker 0. I. Test Engineer

Havid C. Meller David C. Miller, Ph.D. SH\&G Certification Officer

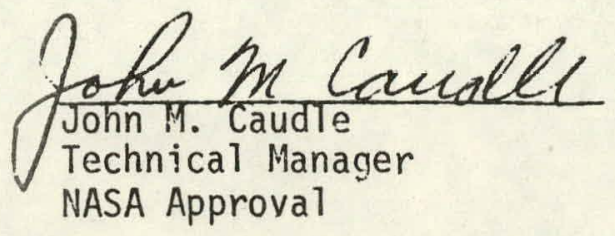

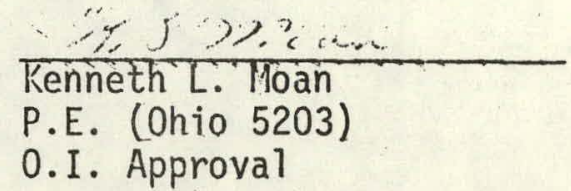

O.I. Approval

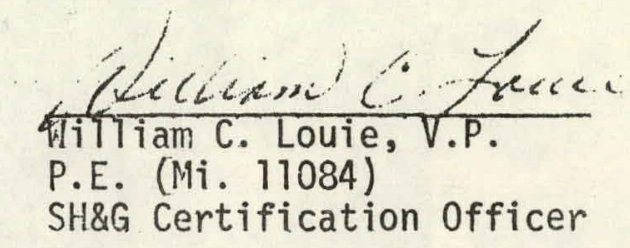



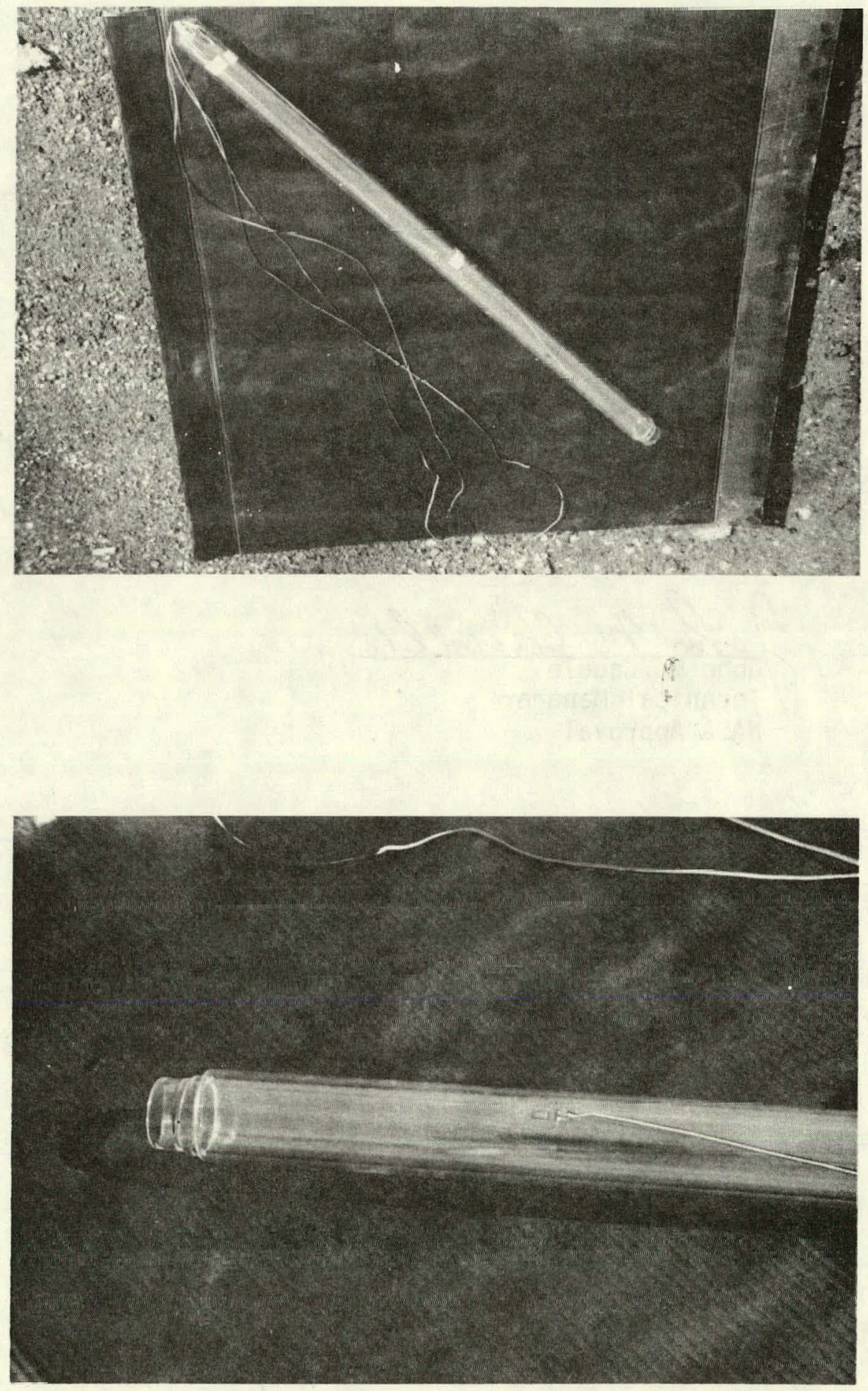

FIGURE 2.2 (a) 


\subsection{Leakage Prevention.}

The design leakage flow rate of the Model SEC-601 collector is $1 \%$ target. The measured leakage flow rate did not change substantially from the initial test to the test after 100 thermal cycles between room ambient and $325^{\circ} \mathrm{F}$. The measured leakage flow rate was less than $0.2 \%$ design flow rate.

\subsubsection{Pressure Test: Non-potable Fluids.}

The criterion of 2.3.1 specifically excludes air as the heat transfer fluid from the requirements of the section. A small but controlled rate of air leakage is desired in an air cooled collector to minimize system pressure fluxuation as a function of air temperature.

\subsubsection{Pressure Test: Potable Water.}

The installation and operation manuals sperify that the col lector be uperated at a positive pressure of 5 inches w.g. or less. The maximum pressure is specified to limit system air pumping power not for structural reasons. Any potable water leakage would occur at the air-liquid heat exchange interface not within the collector.

\subsubsection{Air Transport Systems.}

The transitiun ducting between the collector manifold and the system ducting is $0.21 \mathrm{Ft}^{2}$. At the design air flow rate of 144 CFM per module, the average air velocity in the transition scction is $700 \mathrm{Ft} . / \mathrm{min}$. and within the limits of air flow velocity as contained within Section $615-4.3$ of HIID MPS (3). 
Review of items 2.3 through 2.3.3 successfully completed.

Rotent Remater Robert F. Romaker

0. I. Test Engineer

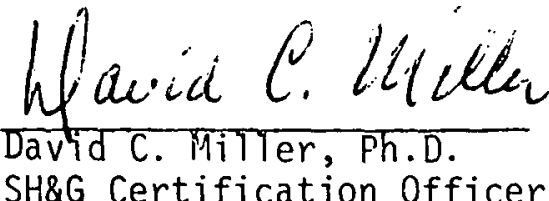

Kenneth L. Hoan

P.E. (Ohio 5203)

0.I. Approval
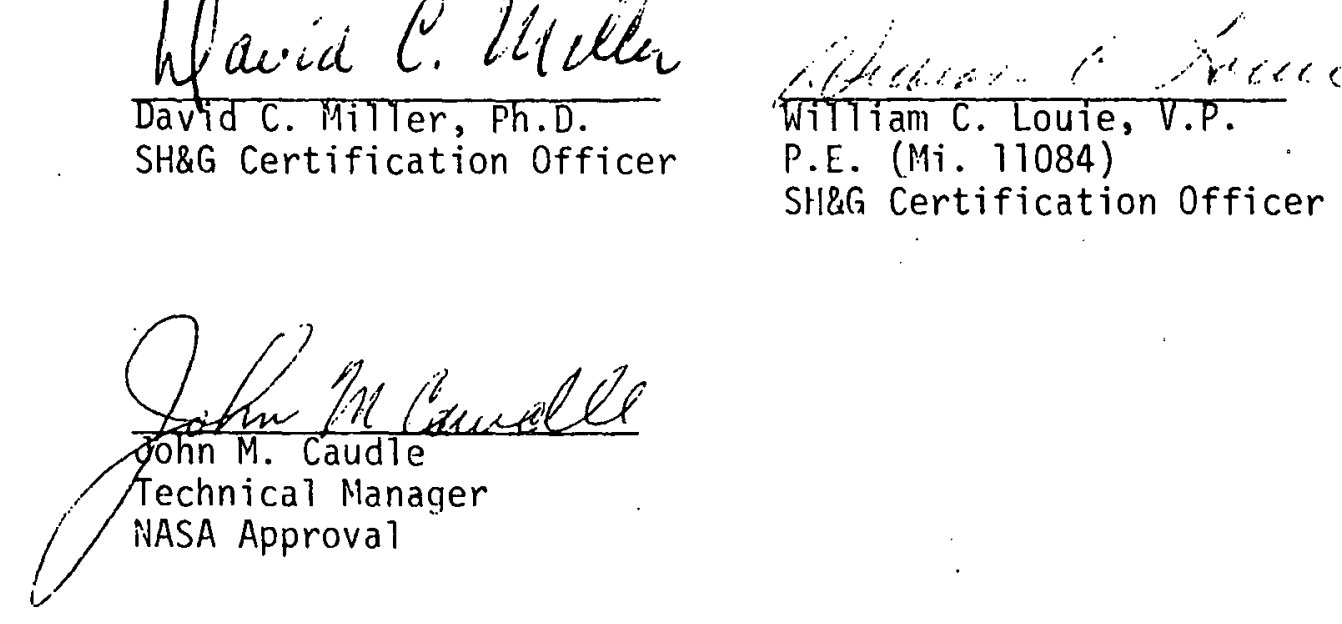
2.4 Collector Adjustments.

\subsubsection{Orientation and Tilt.}

The drawings, specifications and installation of the Model SEC-601 collector were reviewed. The collector may be mounted in any fixed orientation or tilt required by the application. There are no structural or flow path imposed restrictions. A south facing orientation with the tube axis north-south optimizes the thermat performance on a daily basis.

\subsubsection{Mutual Shadowing.}

The problem of mutual shadowing between multiple collectors is negated so long as the collectors are installed in a single plane relative to the axis of the tube elements.

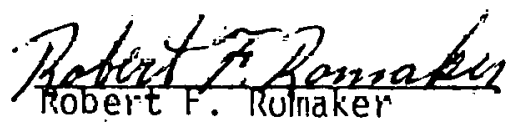

O.I. Test Engineer

Keninelir L. Moan

P.E. (Ohio 5203)

0.I. Approval

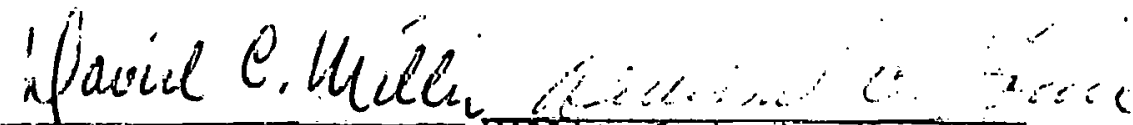
Datid C. MitTer, Ph.D. Withiam C. Louie, V.P. SH\&G Certification P.E. (Mi. 11084)

officer

Shal Certification officer 


\subsection{Heat Transfer Fluid Quality.}

2.6.2. The 144 ERDA collector array, under test for in excess of one year, was inspected and no significant accumulation of dust was detected. Review of thermal performance data for November, 1977, indicates no deterioration in thermal performance due to the accumulation of deposits of dust or dirt after eight months of operation. The critical absorber surface is protected in a vacuum environment; the cover tube surfaces appear to be self cleaning based on a review of the performance data taken over a period of approximately eight months. Air filtration to the collector should have a minimum ASHRAE arrestance of 60 percent. Pressure drop through the filtration unit should be minimized $(0.1$ inches watergage at 150 SCFM is recommended) in order to restrict air pumping power requirements.

Review of items 2.6 through 2.6.2 successfully completed.
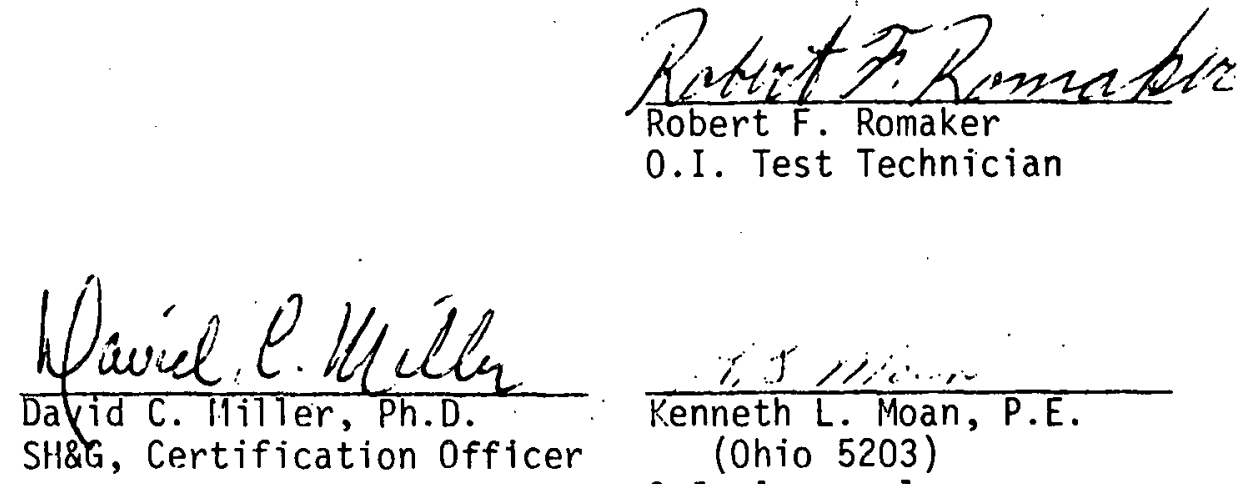
0.I. Approval
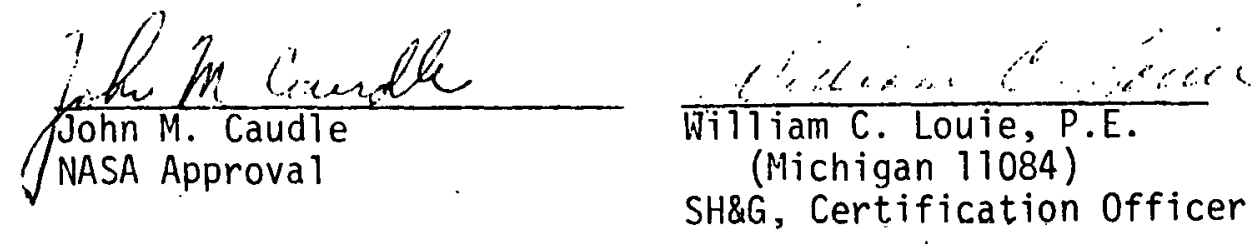


\subsection{Structural Design Basis.}

The capability of the Model SEC-601 collector to meet the provisions of MSP [1] and/or ANSIA]19.1[4] has been demonstrated by the physical testing of a complete seventy two (72) tube module to the requirements of the applicable criterion of the sub-sections of Chapter 3 -- Structural, of the Interim Performance Criteria. A complete module was mounted in a load test fixture as shown in the sequence of photographs Figure 3.1(a) through 3.1(j). A sleel relnforced concretc floor was used as the test fixture base. Two $X$ ten inch boards were used as risers to elevate the collector module above the plane of the floor to provide clearance for the inlet and outlet transition ducts. Sections of the recommended diffuse backing screen (Alcoa 4-inch ribbed Bone White \#K2028-30, flourocarbon) were attached to the top surface of the stringers. The twenty mounting pads of the Model SEC-601 collector module were attached to the stringers using blind hole (one per pad) Molly mounting bolts. A two section air bag was layed on top of the collector tube elements. A reaction element, isolated from the collector, was installed. This allowed an air pressure within the air bag to impose a uniform load on the collector elements with the magnitude of the load a direct function of the air pressure within the air bags. The air pressure in the air bag was controlled with a two stage pressure regulator operating off of shop line pressure. An air bleed to ambient, downstream of the pressure regulator, was added to improve the stability of the system. Dial indicators were mounted to determine the deflection under load at four representative locations of the collector module. These are indicated in Figures $3.1(h)$ and $(i)$. The leakage flow rate 
at a manifold pressure of 1 inch $w . g$. was monitored constantly and was used as the primary evaluation of the effect of physical loading on collector operation.

3.1.1 Applicable Standards and 3.1.2 Service Loads were reviewed and the definitions and requirements found to be acceptable without exception.

1. Dead load. The dead load of the SEC-601 module, fully assembled is 300 pounds as determined by weighing a completed module.

2. Live loads. Since air is used as the heat transfer fluid, the cooling fluid does not contribute to any appreciable live load. Snow does not add a significant live load to the collector. Any snow build up first penetrates between the spaced tubular elements and acts upon the basic roof structure. Increased snow depths build up snow behind (roof side) of the tubular elements, surround the tubular elements and subsequently cover the tubular elements. Except for a minor degree of loading of the manifold, the live load due to snow on the collector is negligible. This condition was observed during the heavy snow conditions of the 1977-1978 winter season in Toledo, Ohio. For test purposes, a snow load equal to the dead load will be as sumed.

3. Wind loads. A wind load equivalent to 40 pounds per square foot (the worst condition found in applicable specifications) will be used. The exposed cross section of the cover tube 
per element is $2.13^{\prime \prime} \times 42^{\prime \prime} / 144=.62 \mathrm{Ft}^{2}$. The wind loading per tube, assuming a drag coefficient of 1.3 is $.62 \times 1.3 \times 40=$ $32.31 \mathrm{lb}$. The maximum frontal area of the manifold is $13^{\prime \prime} \times 12^{\prime}=$ $13 \mathrm{Ft}^{2}$ and the wind loading is $520 \mathrm{\#}$. The total load is $72 . \mathrm{X}$ $32.21+520=2846$ pounds $=.20$ pounds $/ \mathrm{in}^{2}$.

4. Earthquake loads: "A common rule (for earthquake loads) is to provide in the associated structure for resistance to horizontal forces equal to one-tenth of the dead and live load supported." Page 12-21, Marks' Mechanical Engineers' Handbook, sixth edition, McGraw Hi11. The earthquake load will be specified as 300 pounds dead load plus 300 pounds live load times 0.1 or 60 pounds.

5. Constraint Loads. Constraint loads caused by the environment and normal functioning of the system are accommodated by system design. The loads would be the result of differences in temperatures and coefficients of expansion of the materials of construction. The collector tube glass elements are attached in a single plane; the opposite (closed end) of the tubular elements are free to float axially and radially. The manifold design represents the only critical subassembly relative to strain induced by differential expansion. Evaluation of this' parameter will be by test and similarity to the 144 tubes ERDA collector array.

6. Constraint loads, foundation settlement. The effect of foundation settlement equivalent to 2 inches per 50 feet in any 
horizontal distance will be evaluated by test.

7. Hail loads. Hail loads are specified as resistance to $3 / 4^{\prime \prime}$ diameter hail without impairment to the functional capability of the collector.

3.2 Failure Loads and Load Capacity.

3.2.1 Ultimate load combinations.

(1) $1.4 \mathrm{D}+1.7 \mathrm{~L}=300(1.4+1.7)=930$ pounds $=.067 \mathrm{psi}$.

(2) $0.9 \mathrm{D}+1.7 \mathrm{~W}=.9 \times 300+1.7 \times 2846=5108$ pounds $=.37 \mathrm{psi}$.

(3) $0.9 D+1.45 E=.9 \times 300+1.45 \times 60=357$ pounds $=.03$ psi.

(4) $1.10+1.3 L+1.7 W=1.1 \times 300+1.3 \times 300+1.7 \times$

$$
2846=5558 \text { pounds }=.40 \text { psi. }
$$

(5) $1.1 \mathrm{D}+1.3 \mathrm{~L}+1.45 \mathrm{E}=1.1 \times 300+1.3 \times 300+1.45 \times 60$

$$
=807 \text { pounds }=.06 \text { psi. }
$$

\subsubsection{Ice Loads.}

The ice load acting on a tubular element for a one inch glazing thickriess is:

$$
\text { Load }=\frac{56 \#}{F t .3}\left[\frac{\pi}{4} \frac{\left.\left(4^{2}-2^{2}\right) \times 42\right]}{1728}=12.83 \# /\right. \text { tube }
$$

And on the manifold surfaces,

$$
\begin{aligned}
& \text { Load } \left.=\frac{56 \mathrm{Af}}{\mathrm{Ft} .} 3 \frac{\left[13^{\prime \prime} \times 12^{\prime}\right.}{12}+\frac{\left.2 \times 9^{\prime \prime} \times 12^{\prime}\right]}{12} \times \frac{1}{12}\right]= \\
& \text { 145\# }
\end{aligned}
$$

Total ice load $=12.83 \times 72+145=1068$ pounds $=.08$ psi. 
(a) (1) $1.4 \times 300+1.7 \times 1063=2236 \#=.16 \mathrm{psi}$.

(4) $1.1 \times 300+1.3 \times 1068+1.7 \times 2846=6557=.45 \mathrm{psi}$.

(b) (1) $300+1068=1368 \#=.10 \mathrm{psi}$

(4) $300+1068+2846=4214 \#=.30$ psi.

See Section 3.2.4 for test procedure and results.

3.2.4 Load capacity.

The air bay was inflated to a maximum pressure of 0.50 psi (6984 lbs. total load) in increments of $0.10 \mathrm{psi}$. The deflections at the four representative locations were monitored as was air leakage flow rate.

$\begin{array}{lcccccc}\begin{array}{l}\text { Air Bag } \\ \text { Pressure } \\ \text { psig }\end{array} & \begin{array}{c}\text { Total } \\ \text { Load } \\ \text { Pounds }\end{array} & \text { (1) } & \begin{array}{c}\text { (2) } \\ \text { IN C H E S }\end{array} & \text { (3) } & \text { (4) } & \begin{array}{c}\text { Leakage } \\ \text { Flow } \\ \text { C.c./Min. }\end{array} \\ 0 & 0 & 0 & 0 & 0 & 0 & 8800 \\ .10 & 1397 & .061 & .061 & .088 & .073 & 8800 \\ .20 & 2794 & .104 & .108 & .148 & .110 & 8800 \\ .30 & 4190 & .135 & .143 & .211 & .146 & 8800 \\ .40 & 5587 & .160 & .170 & .255 & .170 & 8800 \\ .50 & 6984 & .183 & .190 & .335 & .202 & 8800\end{array}$

A plot of the maximum deflection versus applied load (location 3) is contained in Figure 3.2.4(a). Neglecting the initial system slack which takes place near the origin, there is a linear relationship of deflection versus load within the limits of experimental error. A review of the experimental data of section 3.2.4 and 3.3.1 indicates an error band of deflection yersus load of the order of .003"/0.1 psi: Thus, to a load factor of 1.7 times design, the load versus deflection curye indicates that all elements of the collector structure are well within their elastic region. 


\subsection{Damage control.}

\subsubsection{Resistance to Damage.}

The collector was subjected to the loading conditions of Criterion 3:2.1, combination (4) with the load factors specified rather than the load factor of 1.0 as allowed by the criterion. The results of the load tests were:

$\begin{array}{clcrccc}\begin{array}{l}\text { Air Bag } \\ \text { Pressure }\end{array} & \begin{array}{l}\text { Total } \\ \text { Load }\end{array} & 1 & \begin{array}{r}\text { Dial Readings } \\ 2\end{array} & 3 & 4 & \begin{array}{c}\text { Leakage } \\ \text { Flow }\end{array} \\ \text { psig } & \text { Pounds } & & \text { I N C.HE S } & & \text { C.C./Min. } \\ & & & & & & \\ 0 & 0 & 0 & 0 & 0 & 0 & 8700 \\ .05 & 698 & .037 & .030 & .046 & .031 & 8700 \\ .10 & 1397 & .060 & .067 & .080 & .055 & 8700 \\ .15 & 2095 & .083 & .092 & .113 & .075 & 8700 \\ .20 & 2794 & .104 & .116 & .139 & .090 & 8700 \\ .25 & 3492 & .121 & .135 & .165 & .105 & 8700 \\ .30 & 4190 & .137 & .155 & .196 & .123 & 8700 \\ .35 & 4889 & .152 & .174 & .228 & .141 & 8700 \\ 0 & \text { Residual } & .010 & .019 & .011 & .010 & 8700 \\ & \text { Deflection } & & & & & \end{array}$

No significant change in leakage flow rate could be detected as a function of loading conditions. The residual deflection upon release of the load is considered to be witnin acceptable limits. No subassembly or component suffered damage of any kind which would require replacement or repair or which would impair the intended function during the service life.

\subsubsection{Glazing design.}

Steel ball drop tests were conducted on six collector tube elements mounted in a manifold section and in an end support bracket. Failure of the cover tube was experienced in each test case when a combination of ball size and drop height reached critical conditions. In no 
case was a failure of the absorber tube experienced. The fractured glass remained in close proximity to the failure point and in all cases within the installed area of the collector. No sign of flying glass representing a safety hazard was experienced.

\subsection{Cyclic loads.}

\subsubsection{Deflection limitations.} Loading conditions

(1) $1.0 \mathrm{D}$ to $1.0 \mathrm{D}+0.5 \mathrm{~L}=300$ pounds to 450 pounds.

(2) $1.0 \mathrm{D}$ to $1.0 \mathrm{D}+0.5 \mathrm{~W}=300$ pounds to 1723 pounds.

A preload cycle from (ID) to $(10+1 W)=300+2846$ or 3146 pounds distributed load was applied to the collector module to reduce system slack. The gages were zeroed and the cyclic testing initiated. The air

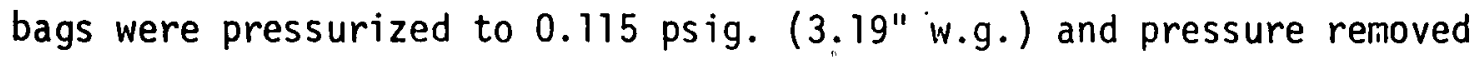
to less than $0.05^{\prime \prime}$ w.g. The cycle was approximately 6 minutes 40 seronds. The leakage air flow with the manifold pressurized to 1 inch, w.g. was 8700 c.c./min. A total of 1072 cycles was accumulated over approximately five days of testing. The deflections measured after 1072 cycles were:

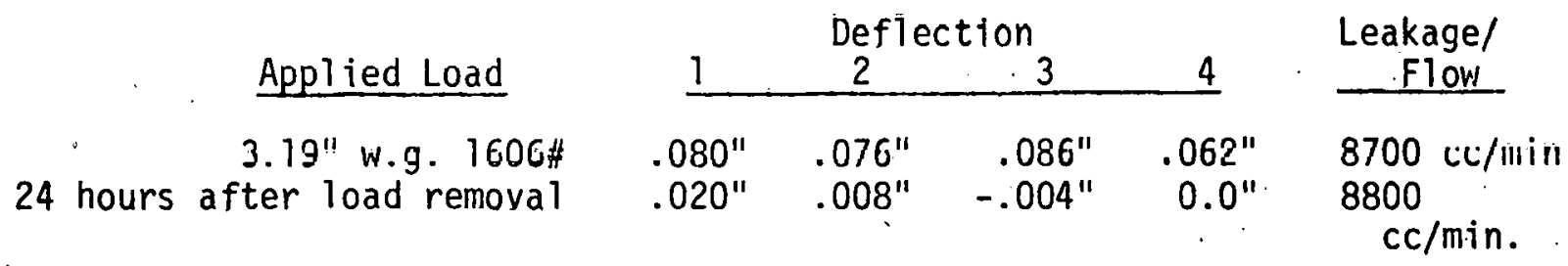

The residual deflections were within $25 \%$ of the deflections with load applied and the leakage air flow test demonstrated that structural integrity was preserved during and after 1000 cycles of load testing. 
3.6 Creep and residual deflection.

\subsubsection{Deflection 1imitations.}

The maximum allowable deflection per the subject criterion is:

$$
d=\frac{1.25 S}{180} \times \frac{0.2 D+1.5 L}{L}
$$

There are 20 mounting attachments between the collector rail support assembly and the structure to which the collector is attached. The deflection of the span of the rail assembly between the manifold and outboard support structure is represented by gage ilo. 2. The deflection of the span of the rail assembly petween mounting pads of the outboard support structure is represented by gage No. 3. The span lengths are 44 inches and 36 inches respectively.

Since $L=D$, the equation for allowable deflection reduces to:

$$
\begin{aligned}
& d=\frac{1.255 \times 1.7}{180} \\
& d_{2}=.519^{\prime \prime} \\
& d_{3}=.425^{\prime \prime}
\end{aligned}
$$

A total distributed load of 700 pounds was applied to the collector for 24 hours. The measured deflections of $d_{2}=.041$ " and $d_{3}=.049 "$ were recorded. These values are well below the allowable limits. The residual deflections measured three hours after removal of the load were $d_{2}=.005 "$ and $d_{3}=-001 "$. These values are well within the allowatle limits for residual deflection of $\mathrm{d}_{2}=.061 "$ and $\mathrm{d}_{3}=.050 "$ " 


\subsection{Hail resistance.}

\subsubsection{Hail size and loading.}

The criterion for resistance to hail contained in the approved Verification Test Plan was that hail size up to $0.75^{\prime \prime}$ in diameter would not cause excessive damage to or impair the performance of the tubular collector elements, manifold or end support brackets. A representative section of the Model SEC-601 collector was subjected to testing under simulated hail conditions at the Center for Disaster Research, Texas State University. A copy of the test report issued by the center is contained in attachment 3.7.1(a). No excessive damage to any collector elements was experienced with hail sizes up to $1.25^{\prime \prime}$ in diameter.

\subsection{Constraint loads.}

3.8.1 Foundation settlement; contraction and expansion.

1. The effect of a differential foundation settlement of 2 inches in any horizontal distance of 50 feet was investigated. One corner of the collector was rigidly attached to a simulated support structure. All other attachments were removed and the remaining three corners shimmed above the plane of rigid attachment as indicated in Figure 3.8.1(a). The numerical values at each of the three unrestrained corners represents the effect of foundation settlenent of 2 inches per 50 feet. The measured leakage flow rate was $8700 \mathrm{cc} / \mathrm{min}$ at a manifold pressure of 1 inch w.g. Shims were then added to each of the unrestrained through corners of the module and leakage dir flow recorded. The shim 
height in inches and the value in relation to the criterion of 2 inches per 50 feet were:

$\begin{array}{ccc}A & \text { Shimed Height } \\ \text { B } & \\ C \\ .323^{\prime \prime} & .580^{\prime \prime} & .480^{\prime \prime} \\ .573^{\prime \prime} & .830^{\prime \prime} & .730^{\prime \prime} \\ .823^{\prime \prime} & 1.080^{\prime \prime} & .980^{\prime \prime} \\ 1.073^{\prime \prime} & 1.330^{\prime \prime} & 1.230^{\prime \prime} \\ 1.323^{\prime \prime} & 1.580^{\prime \prime} & 1.480^{\prime \prime} \\ 1.573^{\prime \prime} & 1.830^{\prime \prime} & 1.730^{\prime \prime}\end{array}$

$A \frac{\text { Relative Deflection }}{B}$

$2^{\prime \prime} \quad 2^{\prime \prime}$

$3.55^{\prime \prime}$

$5.10^{\prime \prime}$

$6.64^{\prime \prime}$

$8.19^{\prime \prime}$

$9.74^{\prime \prime}$ $2^{\prime \prime} \quad 2^{\prime \prime}$

$2.86^{\prime \prime}$

$3.73^{\prime \prime}$

$4.59^{\prime \prime}$

5.45 ".

$6.31^{\prime \prime}$ $2.52^{\prime \prime}$

$3.38^{\prime \prime}$

$4.24^{\prime \prime}$

$5.10^{\prime \prime}$

$5.97^{\prime \prime}$
Air Leakage

Flow Rate

cc/Min.

8700

8700

8700

8700

8700

8700

The data demonstrates that the collector can withstand 3 to 5 times the criterion for foundation settlement without damage or impairment of performance of the collector.

2. The effect of constraint loads arising from thermal expansion or contraction is reported and evaluated in Section 5.2.

\subsection{Ponding conditions.}

\subsubsection{Design provisions.}

Physical inspection of the Model SEC-601 collector roof installed for the thermal performance testing of Section 1.3 demonstrates that no potential exists for the accumulation of water. Visual observation during and after severe rain conditions also confirms that no ponding conditions exist. 
Review of items $3.1,3.1 .1,3.2,3.2 .1,3.2 .2,3.2 .4,3.3,3.3 .1$, $3.3 .2,3.4,3.4 .1,3.6,3.7,3.7 .1,3.8,3.8 .1,3.9,3.9 .1$ are successfully completed.
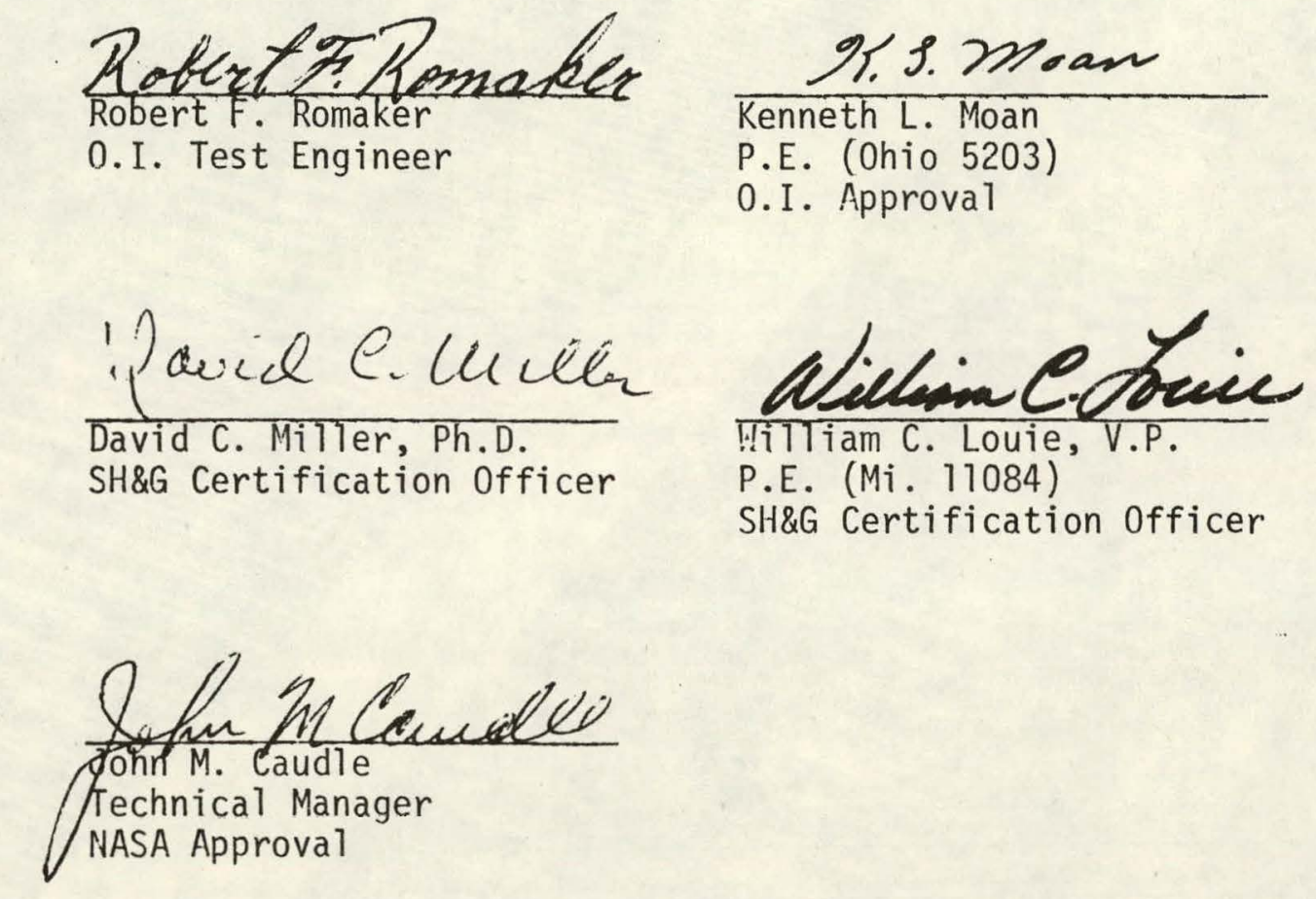


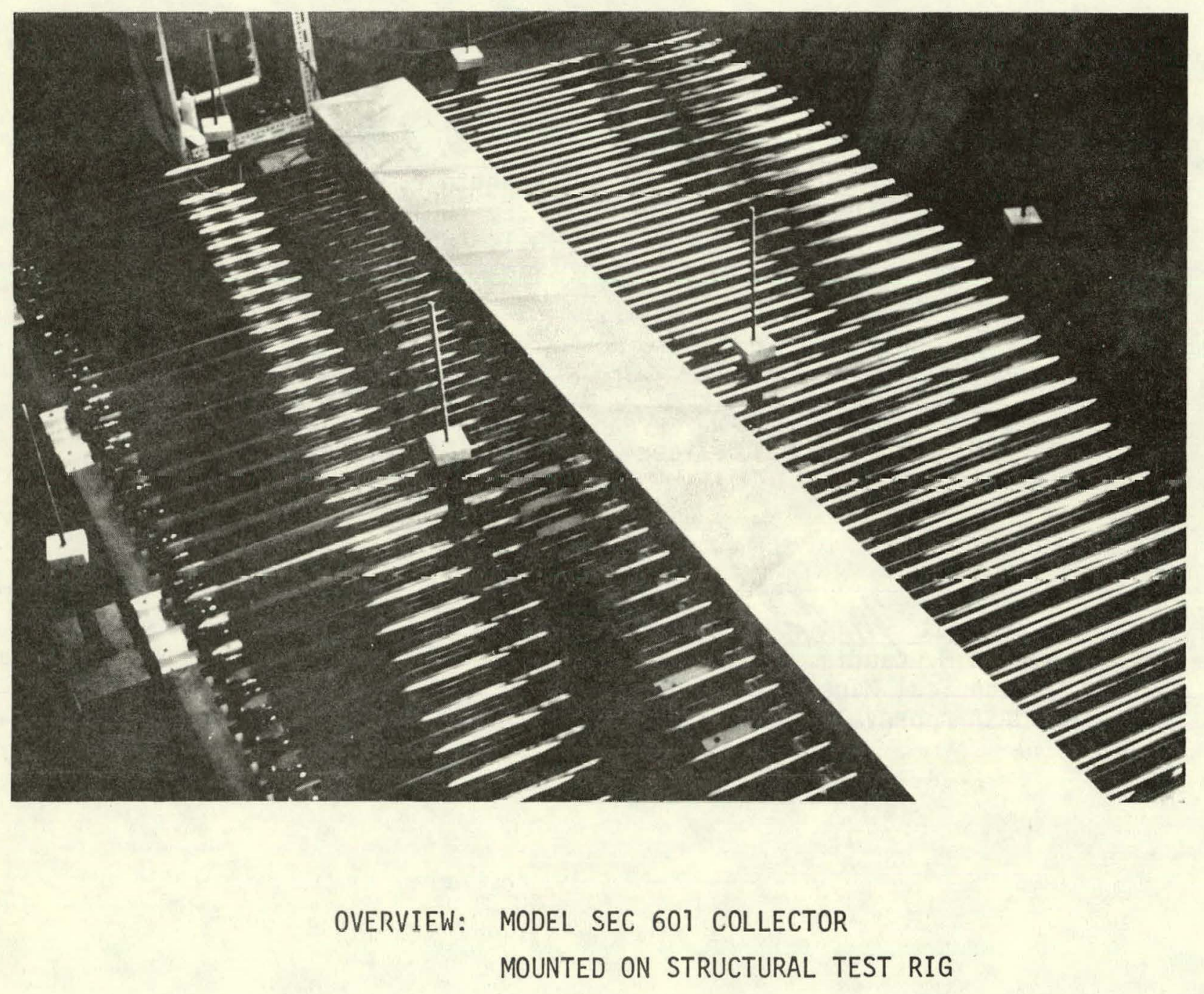

Figure 3.1 (a) 


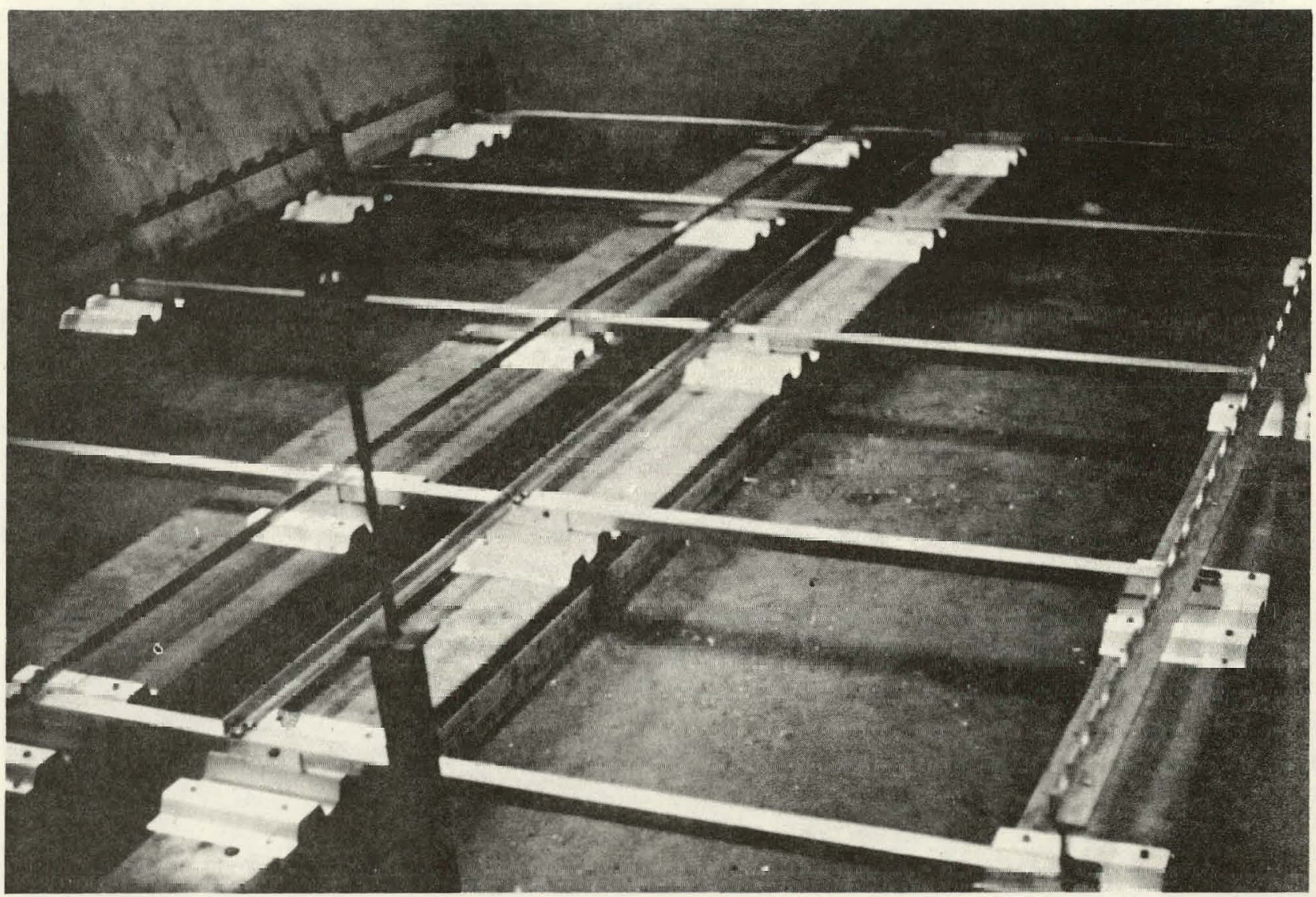

LOAD TEST FIXTURE BASE; $2 " \times 10 "$ STRINGERS, MODULE SUPPORT STRUCTURE.

Figure 3.1 (b) 


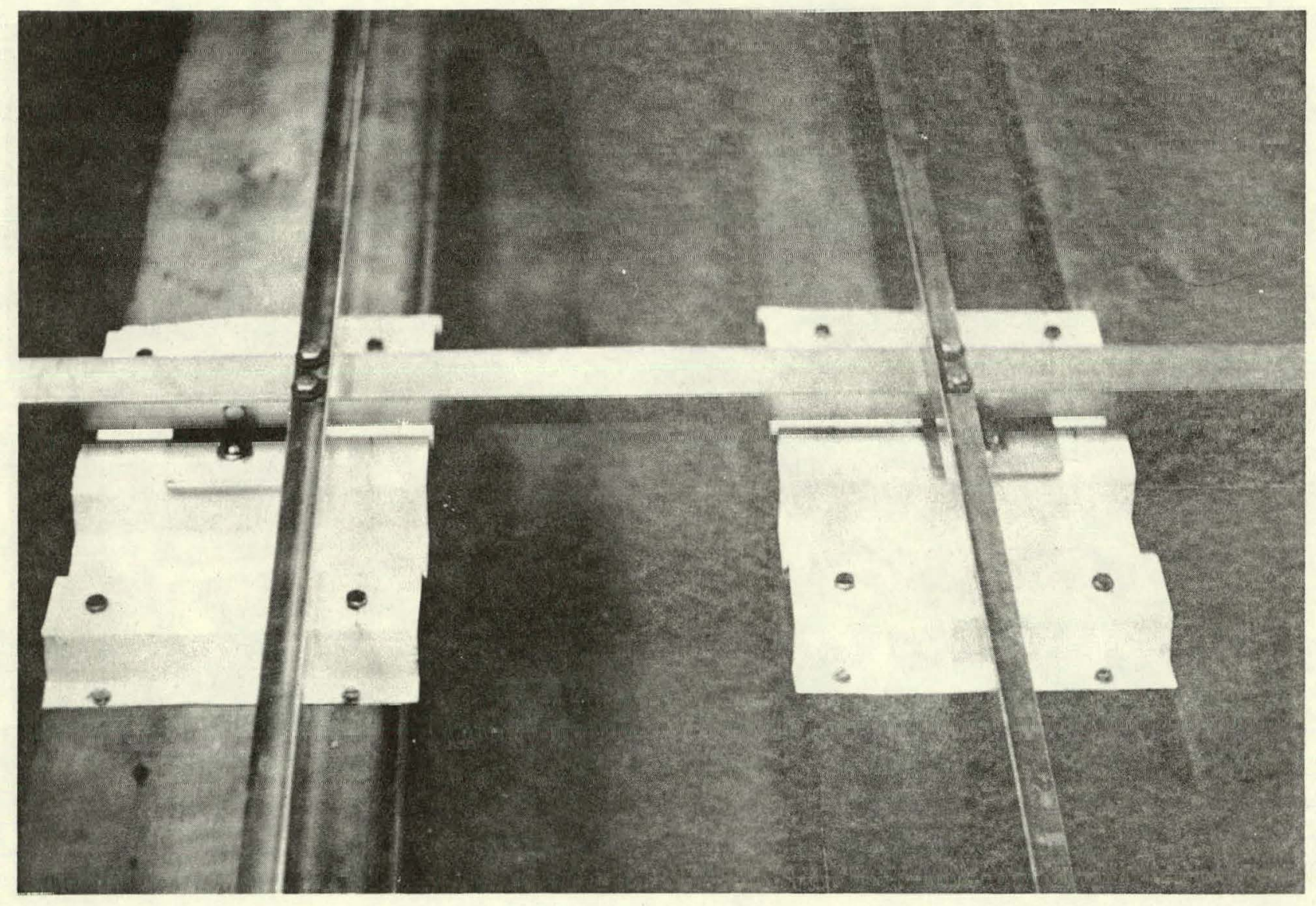

CLOSE UP: T BAR SUPPORTS; MOUNTING PADS SECTIONS OF ALCOA 4-INCH RIB BONE WHITE \#K2028-30, FLOUROCARBON DIFFUSE REFLECTANCE BACKING SCREEN .

Figure 3.1 (c) 


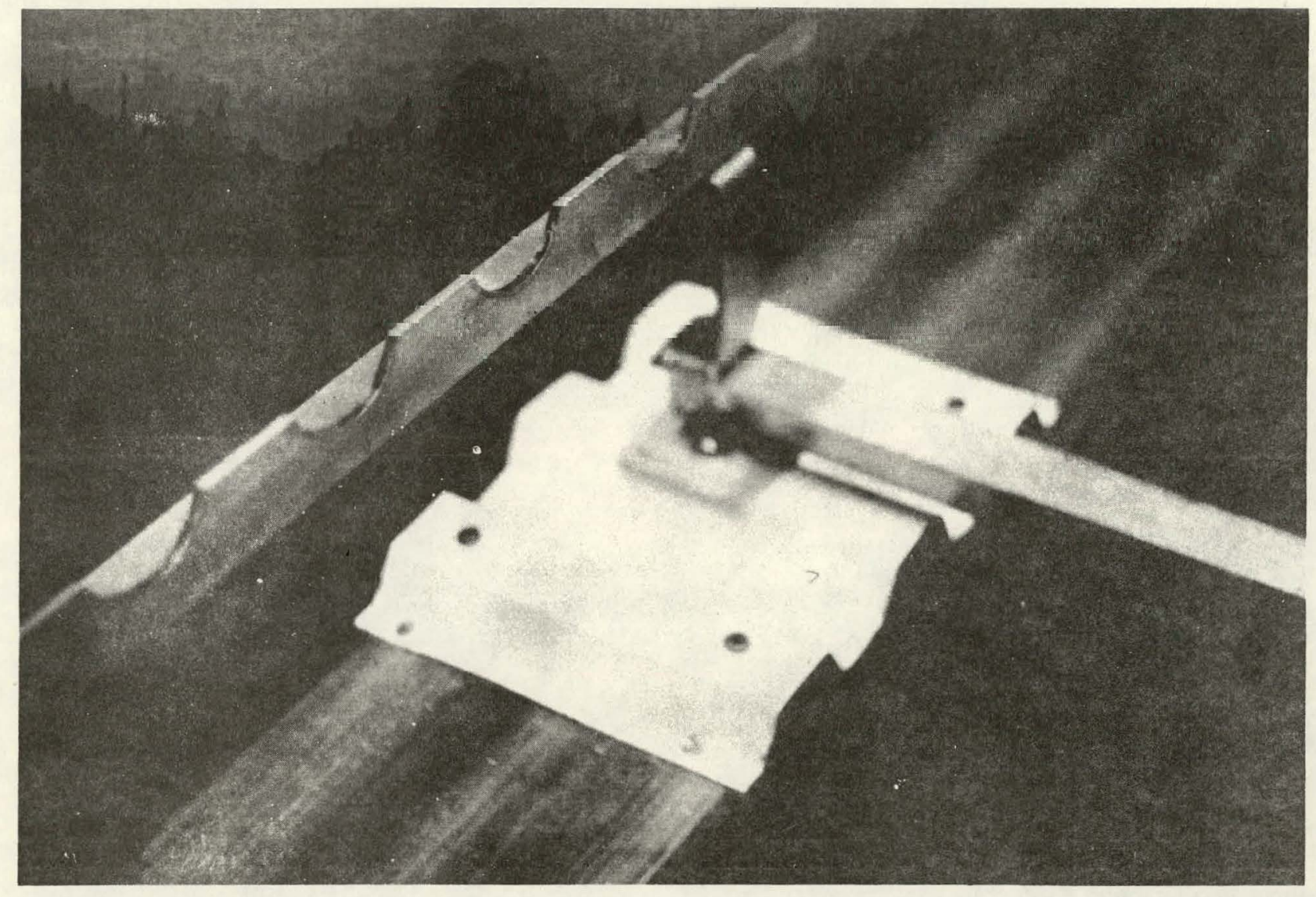

CLOSE UP: OUTBOARD SUPPORT STRUCTURE, STAND OFF, T BAR, ROOF MOUNTING PAD, SECTION OF ALCOA. BONE WHITE BACKING SCREEN.

Figure 3.1 (d) 


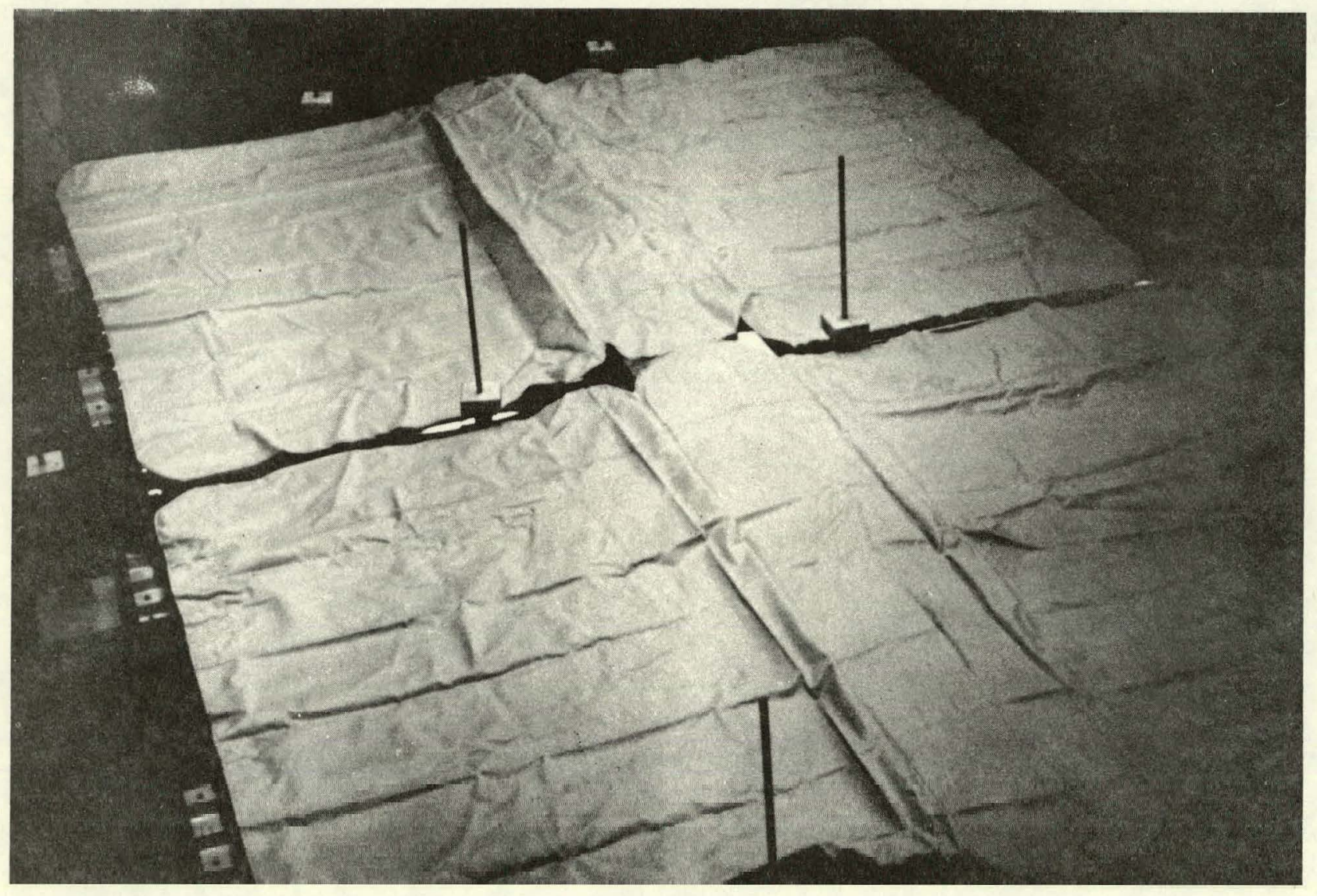

TWO SECTION AIR BAG; REACTION ELEMENT STAND OFF SUPPORTS.

Figure 3.1 (e) 


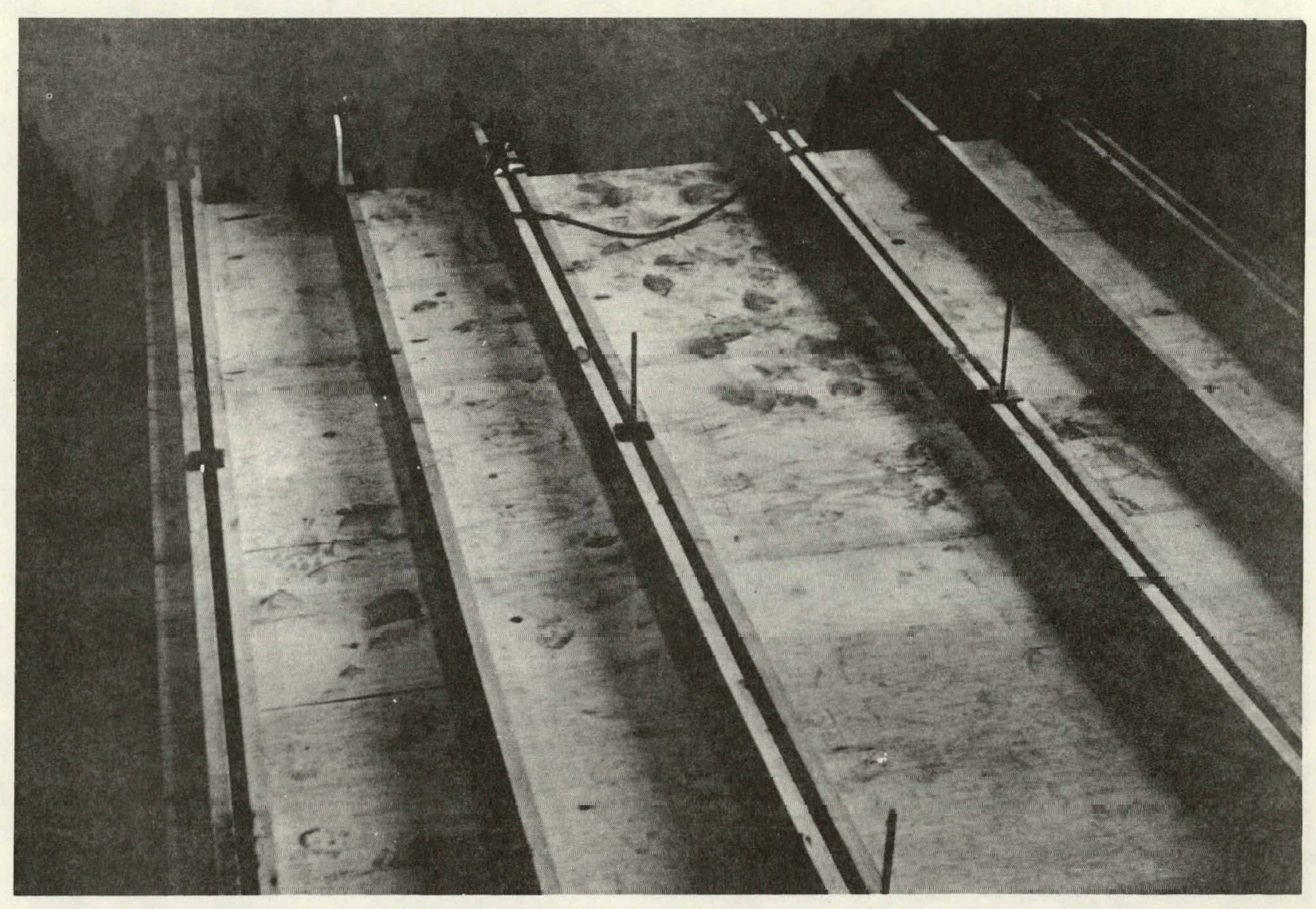

REACTION MEMBER MOUNTED IN PLACE

Figure 3.1 (f) 


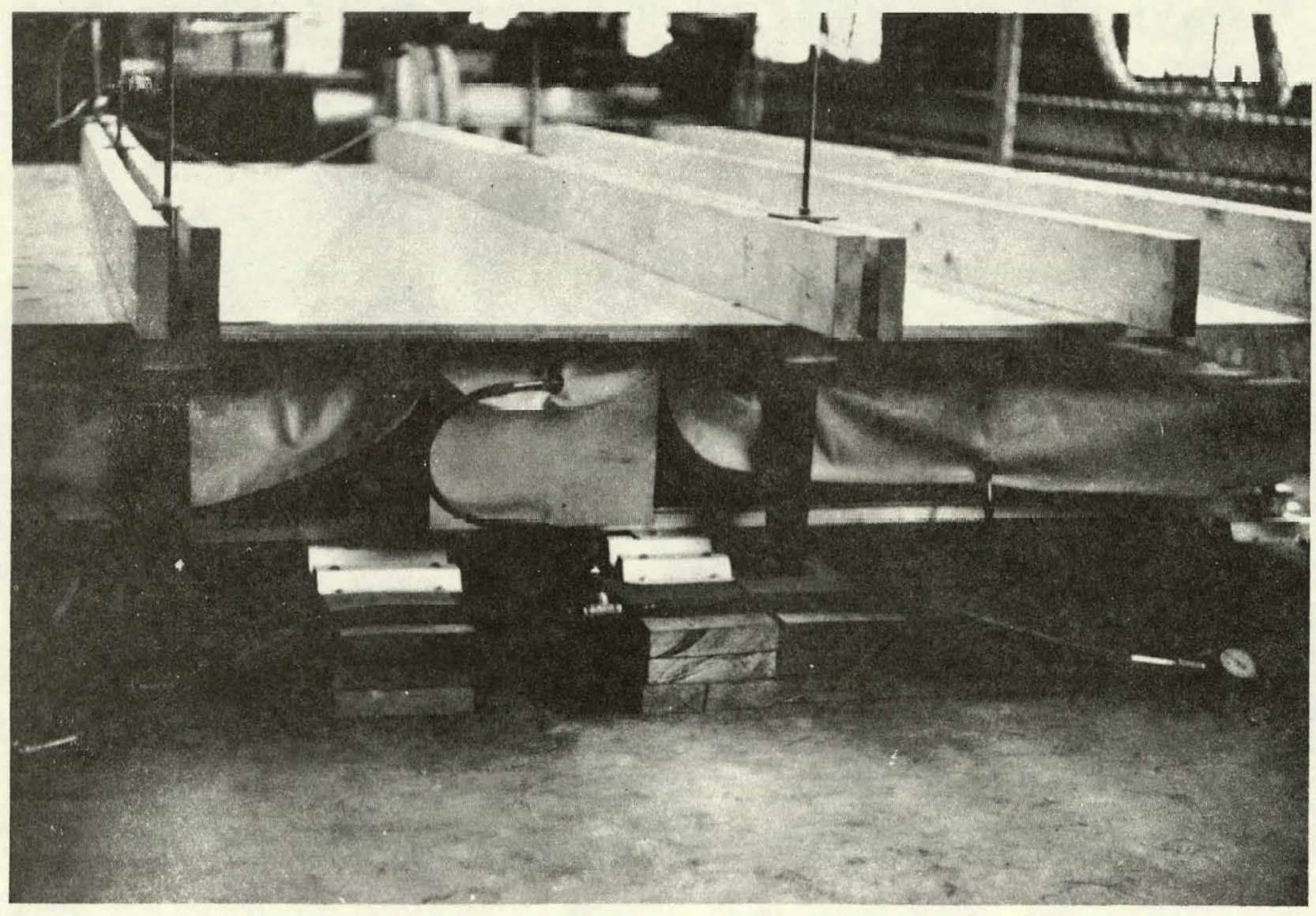

CLOSE UP: REINFORCED CONCRETE FLOOR; $2 " \times 10^{\prime \prime}$ STRINGERS; MODEL SEC 601 COLLECTOR; AIR BAG; REACTION ELEMENT.

Figure $3.1(\mathrm{~g})$ 


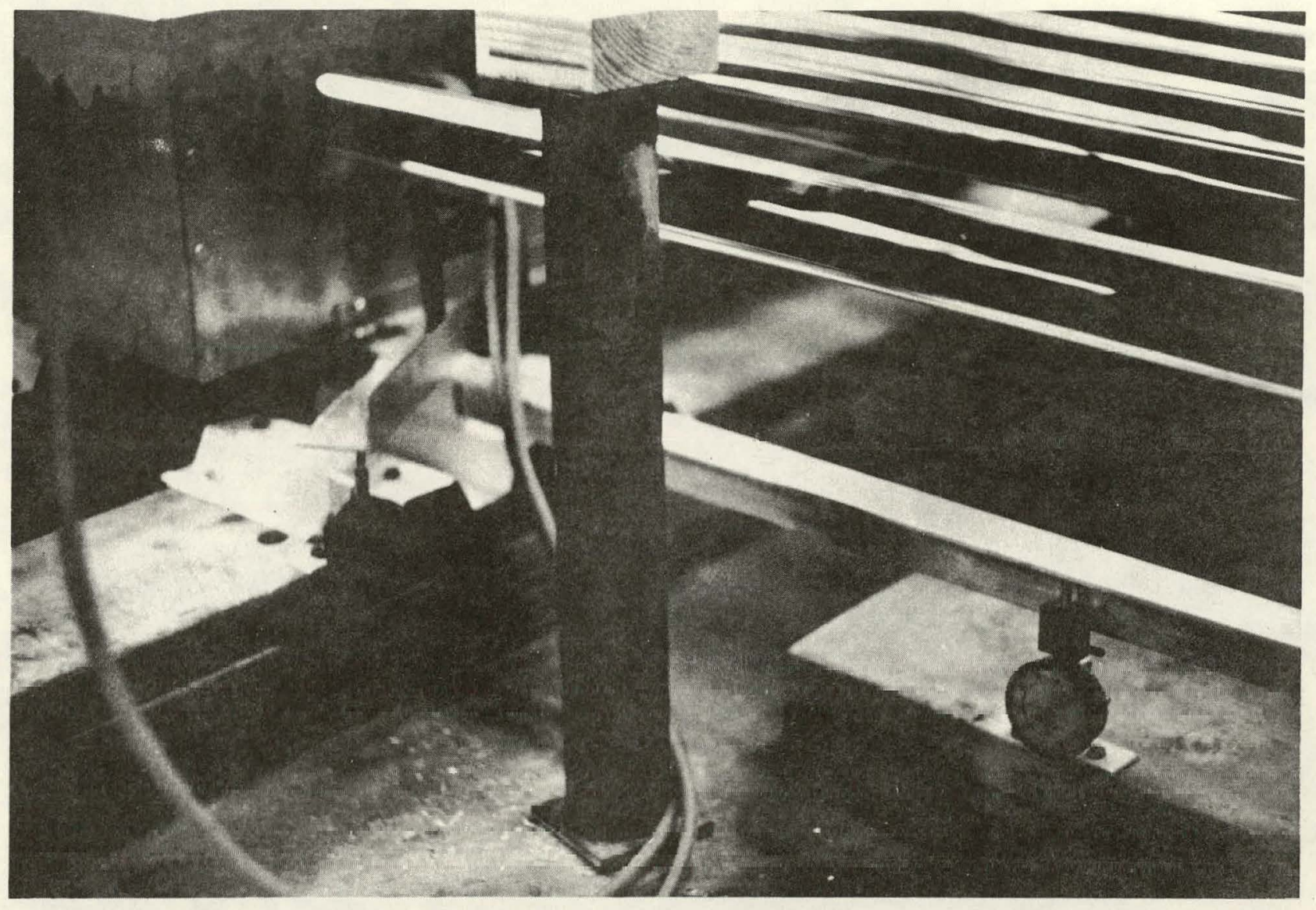

DIAL INDICATORS: DEFLECTION POSITIONS NO. $1 \&$ NO. 2.

Figure 3.1 (h) 


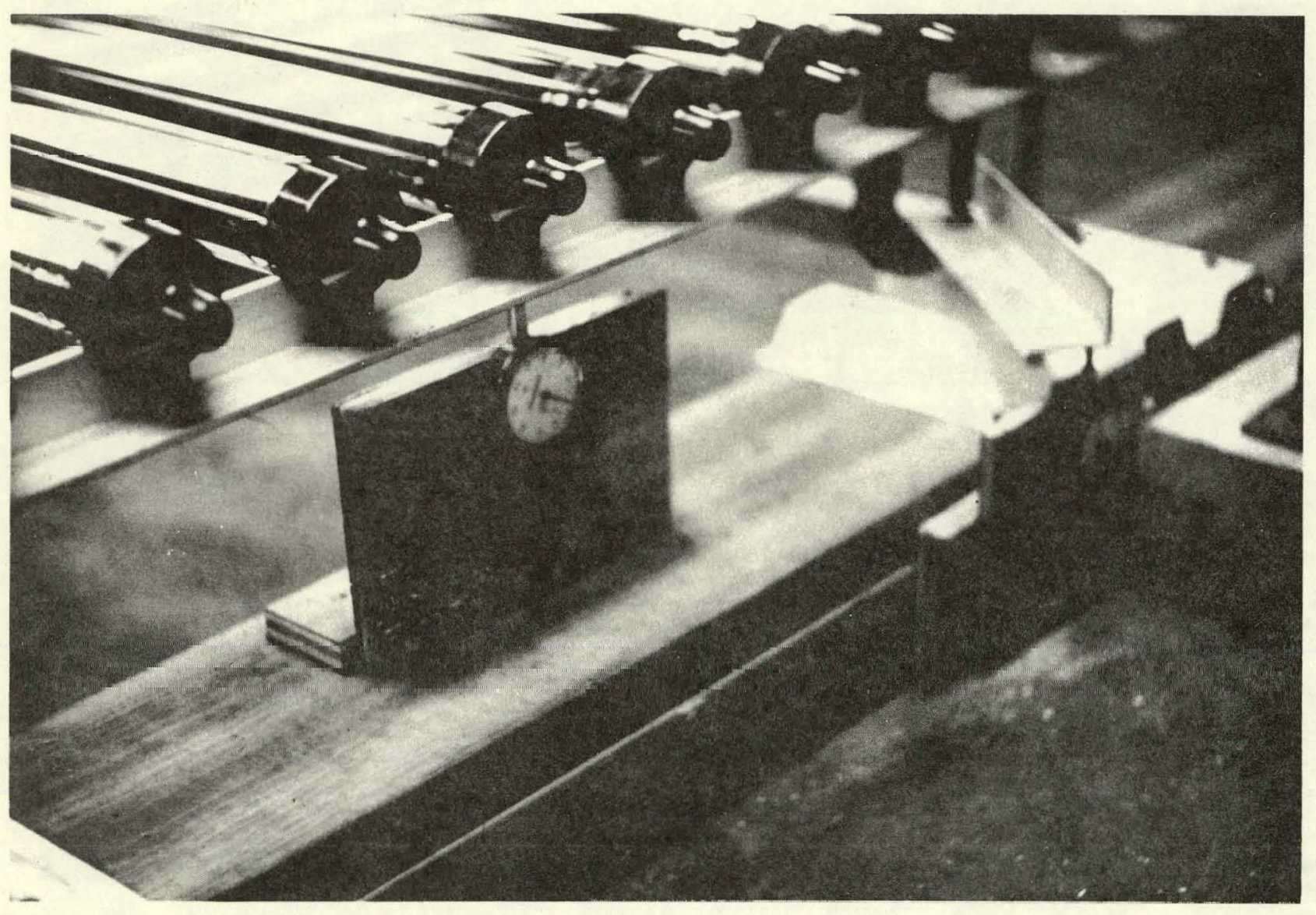

DIAL INDICATORS: DEFLECTION POSITIONS NO. 3 \& NO. 4.

Figure 3.1 (i) 


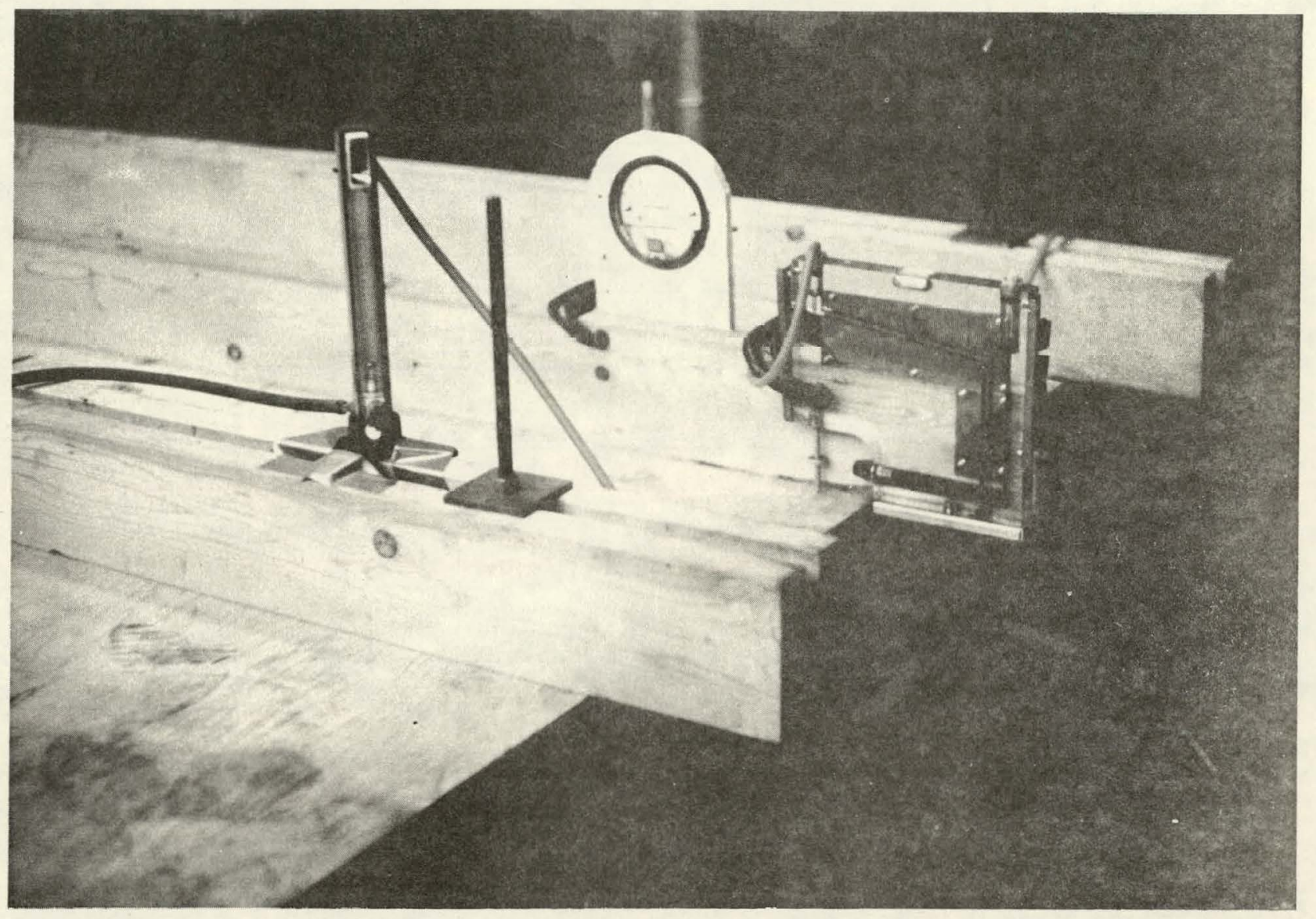

LOAD TEST FIXTURE; MEASUREMENT EQUIPMENT:

LEFT: MATHESON, BALL FLOAT FLOW METER LEAKAGE FLOW

CENTER: PRESSURE GAGE, 0 to 30 INCHES, WATER COLUMN. AIR/BAG PRESSURE / MANIFOLD PRESSURE

RIGHT: INCLINOMETER, 0 to 5 INCHES, WATER COLUMN. MANIFOLD PRESSURE / AIR BAG PRESSURE.

Figure $3.1(j)$ 


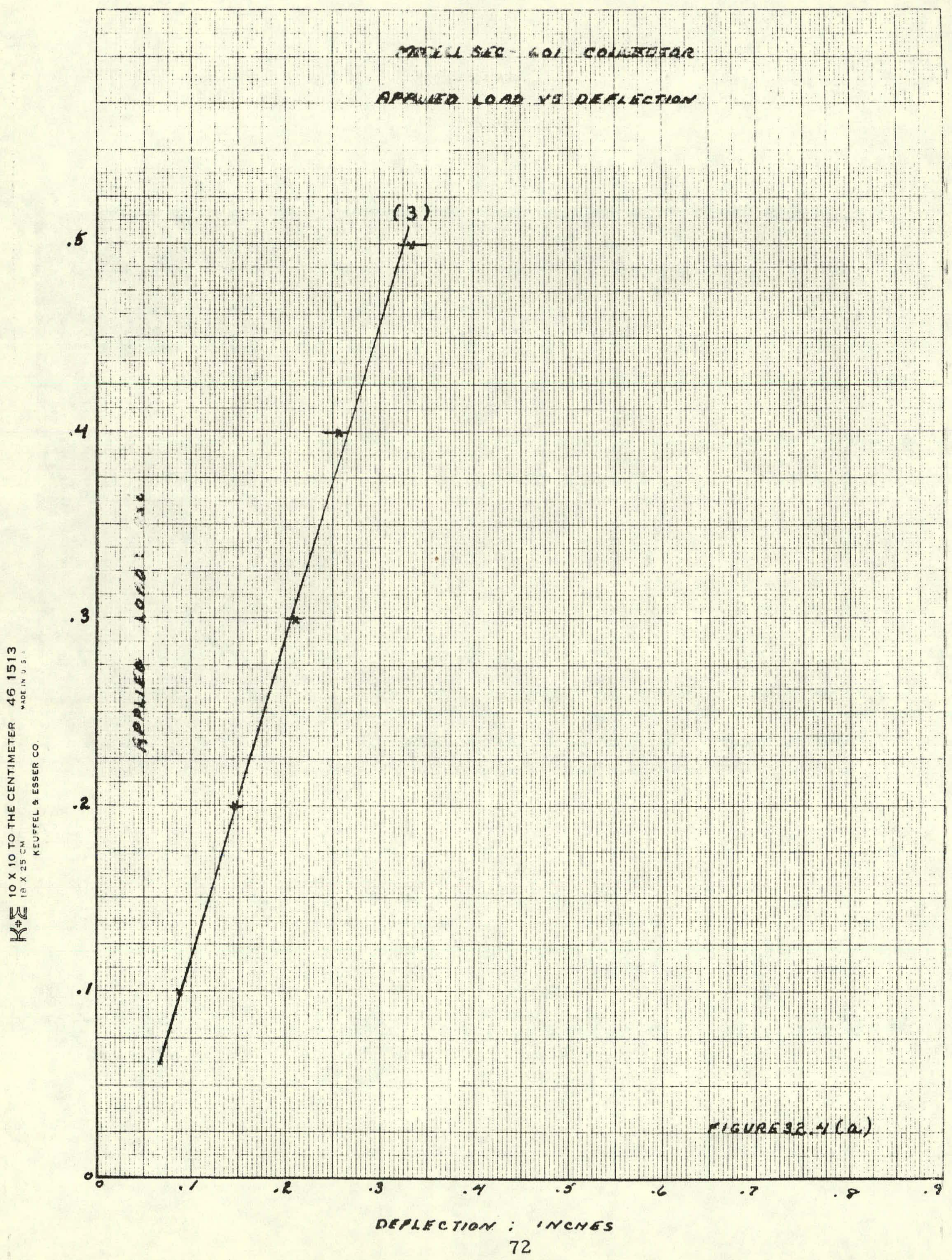


Report on Hail Impact Tests

Conducted on Owens-I11 inois

Liquid and Air Solar Collectors

Tests Conducted at

Texas Tecir University

March 24-25, 1978

\section{Milton L Smith \\ Milton L. Smith, Ph.D., P.I:. \\ Associate Professor of I.E. \\ and Computer Science}


Report on Hail Impact Tests

on Owens-Illinois Solar Energy Collectors

Impact tests were conducted on a 12 tube liquid collector and a 12 tube air collector for Owens-Illinois on March 23 and March 24, 1978 at Texas Tech University. The missiles used in the tests were spherical iceballs that simulate hailstones. Missile diameters of 1.0 inch, 1.2 inch and 1.5 inch were used.

A compressed air cannon and photocell timing device were used to fire the missile at a collector tube. In each trial a tube was selected and missiles were fired at increasing velocities until breakage occurred. The velocity resulting in breakage was recorded and photographs were made when the breakage was such that it would be apparent in a photograph.

All impacts were made approximately 9 inches from the top of the collector tube. Except where noted, the impacts were normal and were centered on the tube. This location of impict is thought to present onc of the more severe cases for this type of collector.

Velocities of hailstones are affected by hailstone diameter and by wind giving the hailstone a horizontal velocity in addition to the vertical velocity. Vertical velocity is given by

$$
V_{T}=53.5 \mathrm{D}^{\frac{1}{2}}
$$

where $D$ is diameter in inches

and $V_{T}$ is in miles/hour

Resultant velocity $V_{R}$ is

$$
V_{R}=\left(V_{T}^{2}+W^{2}\right)^{\frac{1}{2}}
$$

where $W$ is wind speed in miles/hour 
Another way to compute $V_{R}$ is

$$
\mathrm{V}_{\mathrm{R}}=\frac{\mathrm{V}_{\mathrm{T}}}{\mathrm{COS} \cdot \theta}
$$

where $\theta$ is the angle from vertical of the liailstones trajector $y$. Figure 1 gives velocity curves for several cases.

\section{Liquid Collector Tests}

Table I presents test results on the liquid collector. The following conclusions can be made:

1. The 1.0 inch iccballs caused no damage cven at velocitios much higher than those normally encountered for this size hailstones. A horizontal wind of 86 miles per hour will be required to give a 1 inch hailstone a $V_{R}$ of 101.2 miles per hour. It appears that the collector call survive 1.0 inch hailstones.

2. The $1.25 \mathrm{inch}$ iceballs gave an average breaking velocity of 73.6 miles per hour; standard deviaion was 9.1. $V_{T}$ for this size hailstone is $60 \mathrm{miles}$ per hour. Tubes 3 and 11 (Tests $D$ and I) were broken at slightly above $V_{T}$. It is probable that 1.25 inch hailstones will break some tubes but will not break others due to the tube variation in strength.

3. The tubes appear vulnerable to hailstones with diametcrs of 1.50 inches and larger.

\section{Air Collector Tests}

Table II presents test results for the air collector. Conclusions from these results are:

1. The tubes should survive most 1.25 hailstones without damage. Average breaking velocity was 92.4 miles per hour with 


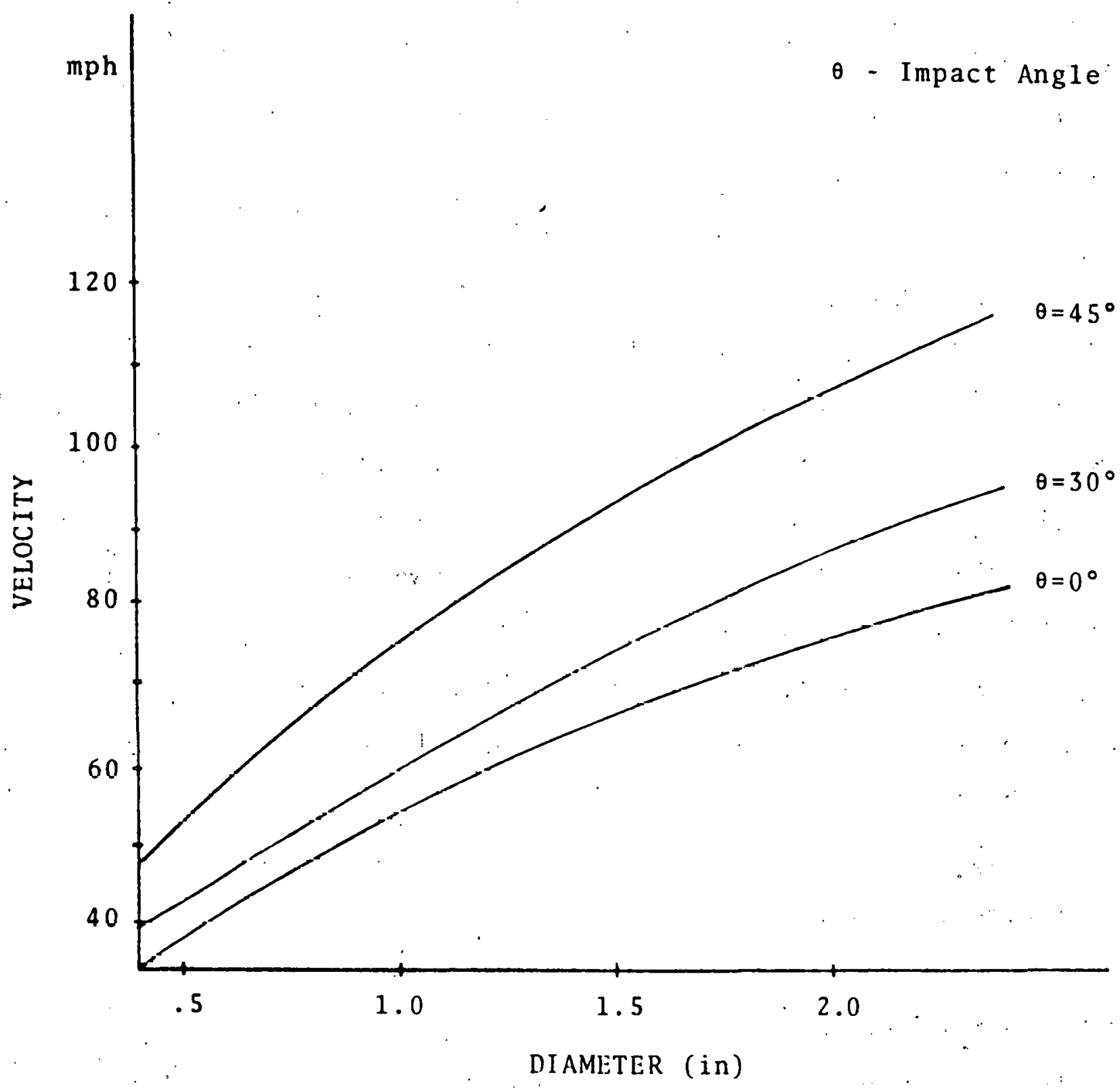

Figure 1 Theoretical Terminal Velocities of Hailstones 
Table I Liquid Collector Test Results.

\begin{tabular}{|c|c|c|c|c|c|}
\hline Test & Tube Number & $\begin{array}{l}\text { Missile } \\
\text { Diameter }\end{array}$ & (in) & Velocity (mph) & Comments \\
\hline A & 1 & 1.00 & & 88.8 & No breakage \\
\hline B & 2 & 1.00 & & 101.2 & No breakage \\
\hline C & 2 & 1.25 & & 72.4 & Internal breakage \\
\hline $\mathrm{D}$ & 3 & 1.25 & , & 63.5 & Internal breakage \\
\hline E & 4 & 1.25 & & 73.0 & \\
\hline F & 5 & 1.25 & & $73: 3$ & \\
\hline G & 6 & 1.25 & & 71.8 & \\
\hline $\mathrm{H}$ & 8 & 1.25 & & 92.6 & 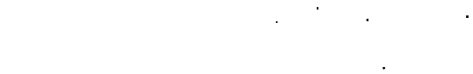 \\
\hline I & 11 & 1.25 & : & 68.3 & Internal breakage \\
\hline $\mathrm{J}$ & 8 & 1.25 & & 83.7 & $\begin{array}{l}\text { Glancing impact } \\
\text { side of tube; no } \\
\text { breakage }\end{array}$ \\
\hline$K$ & 1 & 1.50 & & 59.9 & $\begin{array}{l}\text { Breakage on first. } \\
\text { impact; actual } \\
\text { velocity for break- } \\
\text { age may be lower. }\end{array}$ \\
\hline
\end{tabular}




\section{Table II Air Collector Tests Results}

\begin{tabular}{|c|c|c|c|c|}
\hline Test & Tube Number & $\begin{array}{l}\text { Missile } \\
\text { Diameter (in) }\end{array}$ & Velocity (mph) & Conments \\
\hline A & 1 & 1.00 & 94.0 & No breakage \\
\hline B & 6 & i. 25 & 86.5 & \\
\hline $\mathrm{C}$ & 7 & 1.25 & 103.3 & No breakage \\
\hline D & 8 & 1.25 & 99.1 & \\
\hline$E$ & 9 & 1.25 & 79.7 & \\
\hline $\overrightarrow{\mathrm{F}}$ & 10 & 1.25 & 86.5 & \\
\hline G & 11 & 1.25 & 99.1 & \\
\hline $\mathrm{H}$ & 12 & 1.25 & 71.3 & $\begin{array}{l}\text { Impact with } \\
\text { collector tilted } \\
\text { back } 45^{\circ}\end{array}$ \\
\hline I & 1 & .1 .50 & 93.4 & \\
\hline $\mathrm{J}$ & 2 & 1.50 & 75.6. & \\
\hline K & 3 & 1.50 & 58.2 & \\
\hline L. & 4 & 1.50 & 73.5 & : \\
\hline$M$ & 5 & 1.50 & 111.1 & \\
\hline
\end{tabular}


a standard deviation of 9.4. The minimum breaking velocity was 79.7 miles per hour; a 1.25 inch hailstone will have a velocity $V_{R}$ equal to 79.7 miles per hour winen wind is blowing at 53.7 miles per hour. The second lowest breaking velocity was $86.5 \mathrm{miles}$ per hour; a $62.5 \mathrm{mile}$ per hour wind will result in 86.5 miles per hour from a 1.25 inch hailstone. These wind velocities are possible in thunderstorms; however they are the exception rather than the rule.

2. Average breaking velocity for 1.50 inch icebalis was 82.4 miles per hour; standard deviation was 20.3. Terminal velocity $V_{T}$ for 1.50 inch hailstones is 65.5 miles per hour. It is expected that some tubes will be broken by 1.50 inch hailstones and that some will survive.

3. The test with the collector at a $45^{\circ}$ angle produced breakage at 71.3 miles per hour. Although it was thought that an impact at an angle other than normal would require a higher velocity for breakage, this one test did nct support that supposition.

\section{Comments on the lest's}

The Owens-Illinois evaucated tube collectors have some unusual characteristics concerning hail survivability due to the collector design. Nost hailstones inpacts will occur with glancing impacts on sides of the tubes rather than at a $90^{\circ}$ angle. All tests except those noted were made at 900 impact angle. By chance some hailstones will miss the tubes and strike betweon adjacent tubes; others will strike at a severe angle us shown in Figure 2 and will cause nio dumage. Test $J$ 


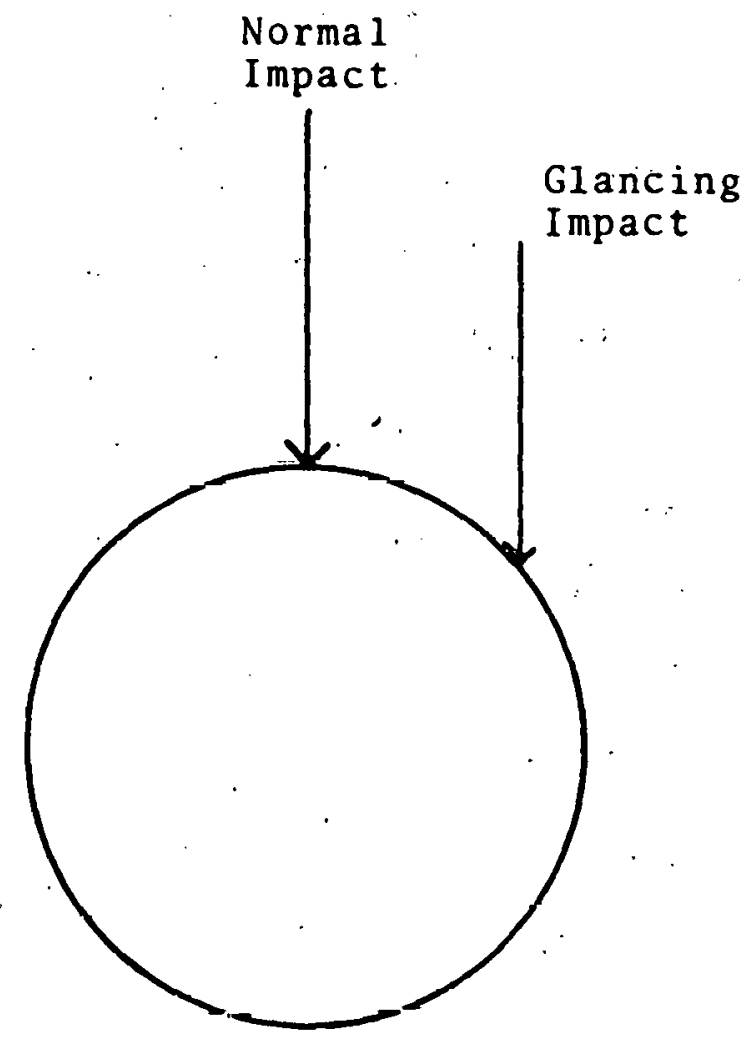

Figure 2. Tube Impacts 
in Table I was made at such an angle, and no damage was observed.

A second unusual characteristic of the Owens-Illinois collectors is the ease of replacement of individual tubes. If one tube in a bank is broken, only that tube must be replaced. Also if breakage is internal and not on the exterior. of the tube, operation can continue until the damaged tube can be replaced. In several cases breakage was internal with the outer tube surface remaining intact; there will be no loss of fluid, but there will be some decrease in performance due to the tubes having losi the vacuum.

The iceball impact tests 1 ikely produce a more severe test. than that from a hailstone at the same velocity. Iceballs are cast uniformly and are at a density that is at the upper limit of the range of hailstone densities. Also the location of impact and impact angle were selected to present a worst case. Results obtained from these tests should be used with caution in warranting survivability in a hailstorm. Hailstones in a given storm are of various sizes; there is no official measurement of sizes and no highly accurate method available for measurement. Also hailstones rapidly decrease in size due to melting. This results in a situation where it is very difficult to establish the size of a hailstone that caused breakage to a collector tube. It is suggested that some type of a hailpad be installed at each location of Sunpac collectors to provide a record of hailstone sizes should this record be needed. 


\section{Photographs}

The following photographs were made after breakage occurred.

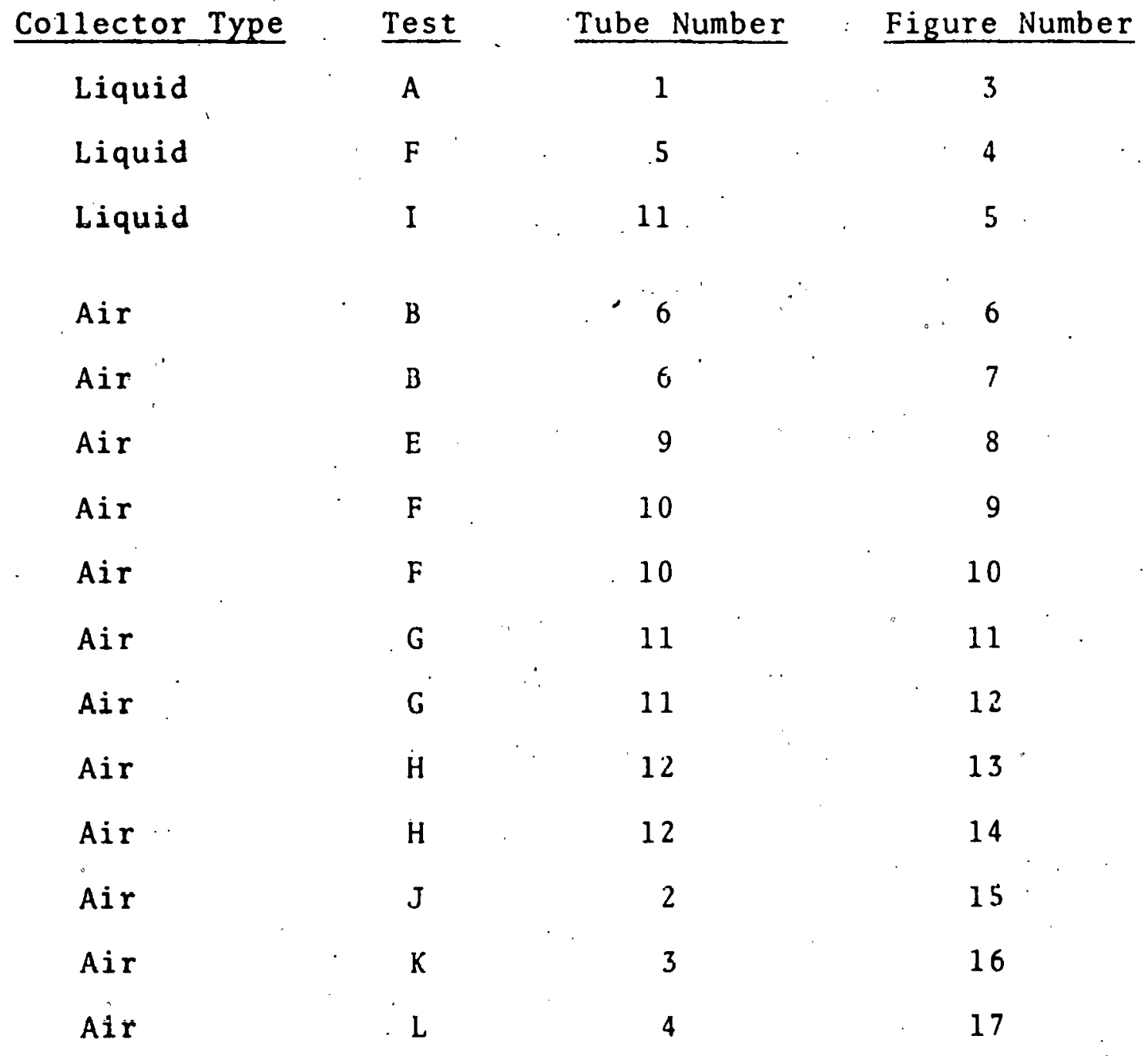

Figure 18 shows the collector positioned for Test H. 


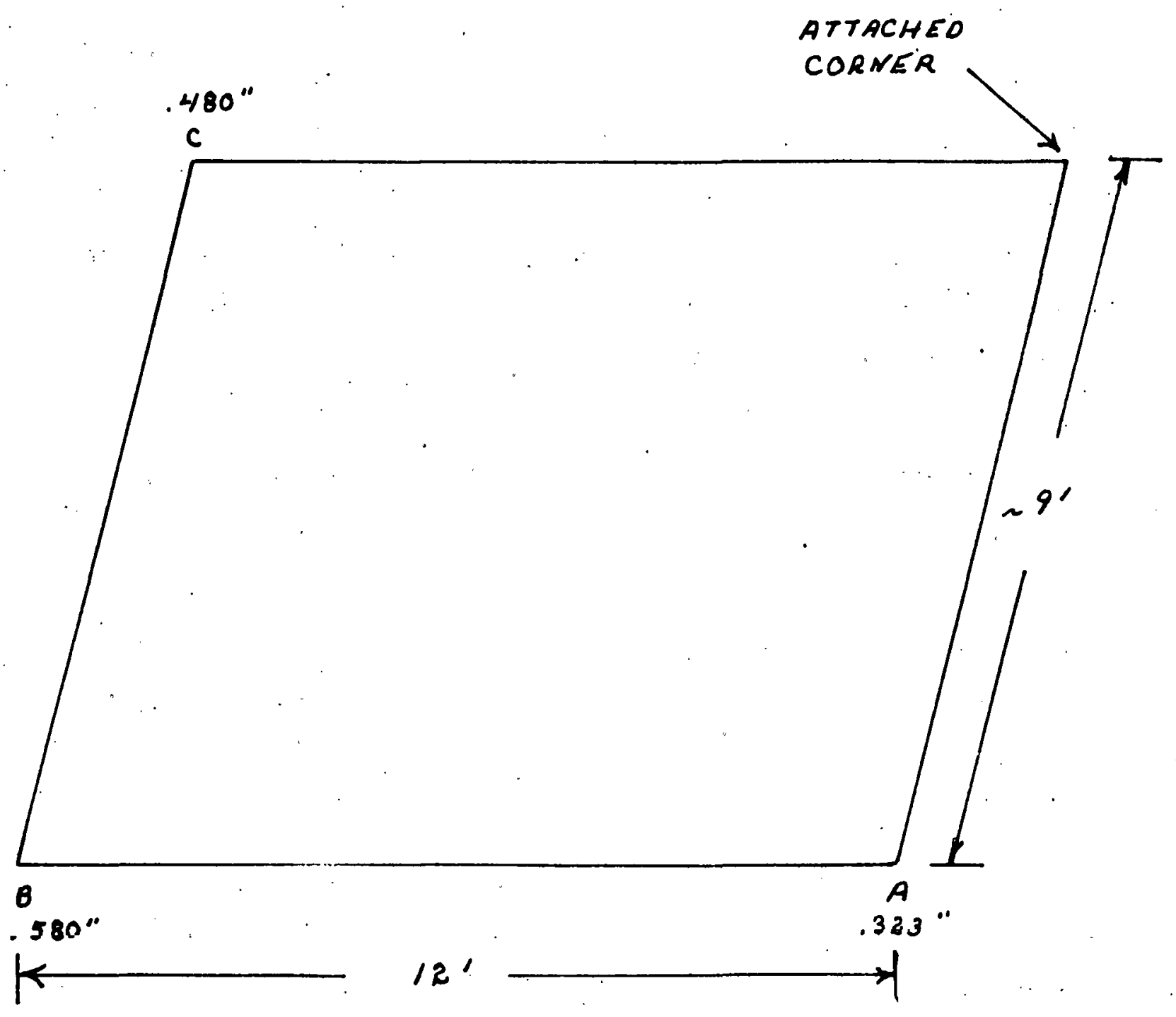

SIMULATED SUPPORT ATTACHMENT

FIGURE $3.8 .1(a)$ 


\subsection{Fail Safe Controls.}

\subsubsection{System Failure Prevention.}

Accelerated life tests are conducted on collector tube elements as a continuing in house program. The DSET outdoor exposure test program, originally planned for use as documentation for this section, has been reduced in duration. The results of the 0.1 . ongoing accelerated life tests are now considered to be more appropriate as documentation. The test consists of heating the internal volume of the absorber tube by a calrod unit. Figure 4.2.1(a) contains a chart of the experimental test results for a standard production tubular ele- , ment exposed for 2035 hours to $500^{\circ} \mathrm{F}$ and an additional 9242 hours at $600^{\circ} \mathrm{F}$. The tubular element was tested periodically for the stagnation. temperature it would reach when subjected to radiation from an indoor solar simulator. The change in the comparative stagnation temperature was from $320^{\circ} \mathrm{F}$ initially, a maximum of $342^{\circ} \mathrm{F}$ and down to a minimum of $300^{\circ} \mathrm{F}$.

The collector tube element life is the most critical component in determining the long term thermal performance of the collector. The accelerated life test data of Figure 4.2.1(a) documents the capability of the collector tute elements to withstand long-tern periods safely and rel iably under no flow conditions.

Attached as Figure 4.2.1(b) is a chart of temperature data derived from the highly instrumented ERDA air collector. The manifold thernocouples were located in the annulus air flow paths as indicated schematically at the bottom of Figure 4.2.1(b). The tube on the inlet side of the manifold was upward facing. The highest temperature recorded 
for convection air reaching the manifold was $210^{\circ} \mathrm{F}$ when the recorded annulus temperature (not for the same tube pair) was $508^{\circ} \mathrm{F}$. Under stagnation conditions the manifold temperature is limited and represents no safety hazard.

Figure 4.2.1(c) contains a plot of the exit air temperature of the air as it leayes the tube annulus and enters the manifold. The ERDA collector array was allowed to soak under no flow conditions until the air temperature in the tube annulus as measured at the axial midpoint of the tube element reached steady state. At solar noon, air flow at $8 \mathrm{lbs} . / \mathrm{min}$. Ft. ${ }^{2}$ was introduced. The decay in temperature of the air in the tube annulus and the transient air temperature at the tube annulus exit plane are recorded as a function of time. The temperature overshoot prior to reaching steady state will be noted. A thermocouple located in the tube annulus is provided with each Model SEC601 collector. "The Operations Manual specifies that the control system shall include the necessary logic and a suitable control element shall be provided to preclude the initiation of air flow when the air temperature in the annulus reaches or exceeds $400^{\circ} \mathrm{F}$. In the event of a control failure, air flow could be initiated after a long period of exposure to high levels of radiation and the manifold could be subjected to a short term high temperature excursion as indicated in Figure $4.2 .1(\mathrm{c})$. No failure mode of the collector will result from such short term exposure. However, repeated exposure to such overtemperature conditions could degrade the insulation properties of the manifold and/or induce an air leakage path. These changes could result in some loss in thermal performance of the collector. 
Several collector tube elements were subjected to thermal shock. The tube elements were heated and cold air introduced as a worse case condition. A chart of the test conditions is contained in Figure 4.2:1(d).

The criterion of Section 4.2.1 are met by similarity of design, material selection, and construction of the ERDA air manifold and the collector tube elements with the Model SEC-601 collector.

Review of items 4.2 and 4.2 .1 successfully completed.

Patertizenonater

Robert F. Romaker

$0 . I$. Test Fngincer

Wavid E. Millin David C. Mitler, Ph.D. SHik Certification officer

John M. Caudre Technical Manager NASA Approvà 1

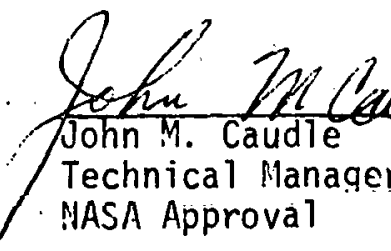

Kenneth 1. Moan

P.E. (Disio 5203)

0.I. Aforoval 


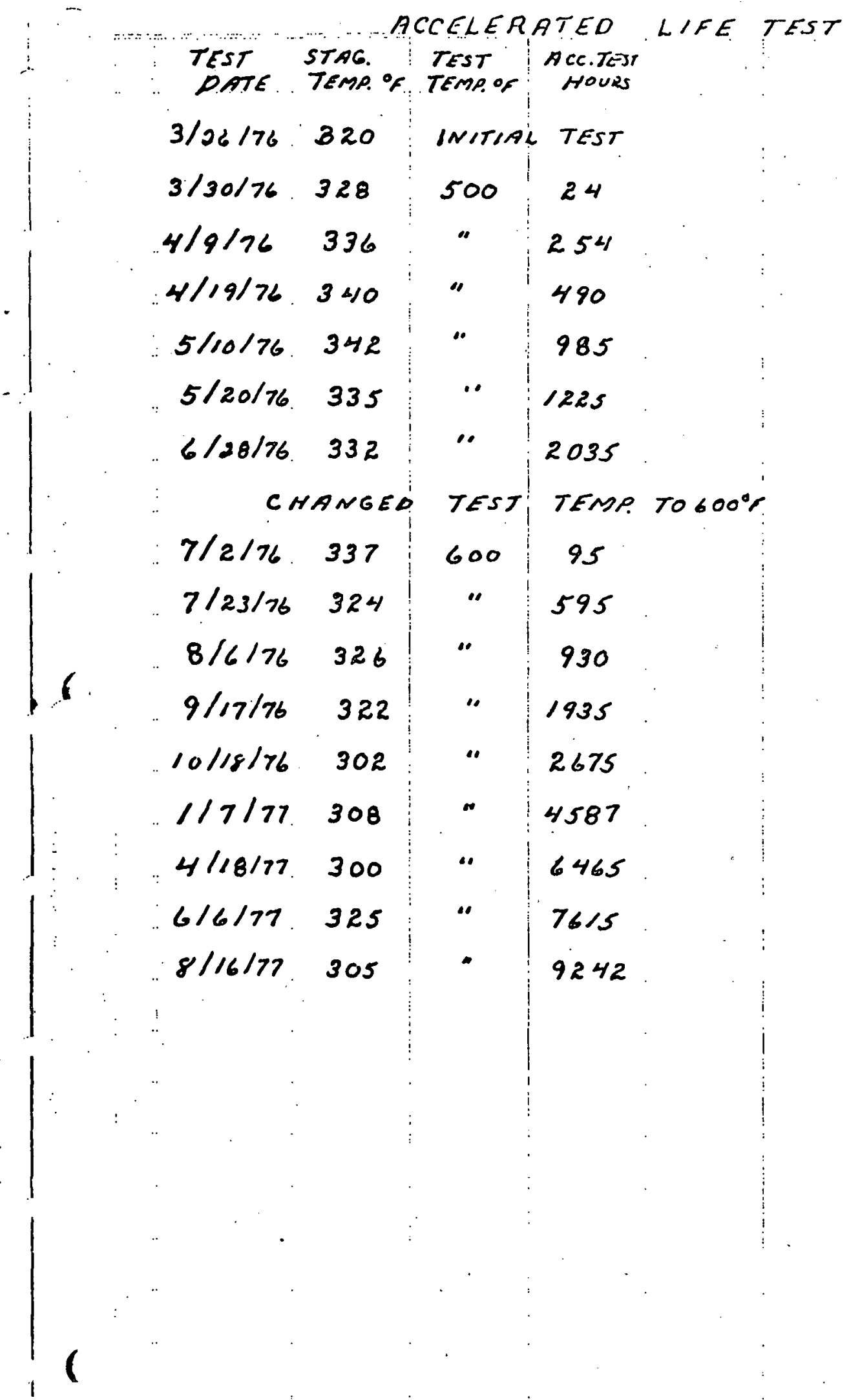

FIGURE 4.2.1 (a) 


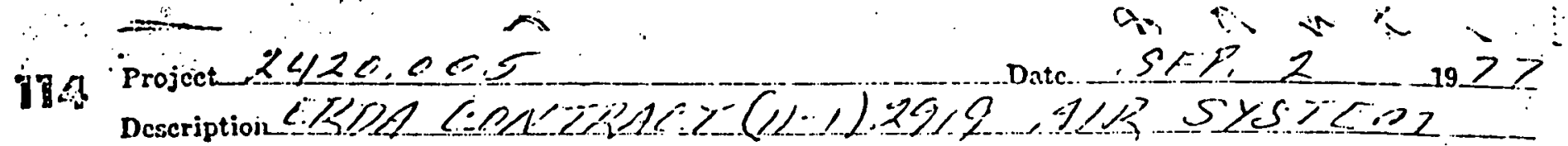

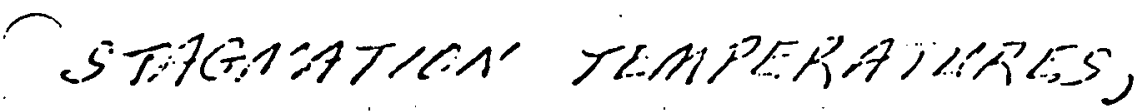

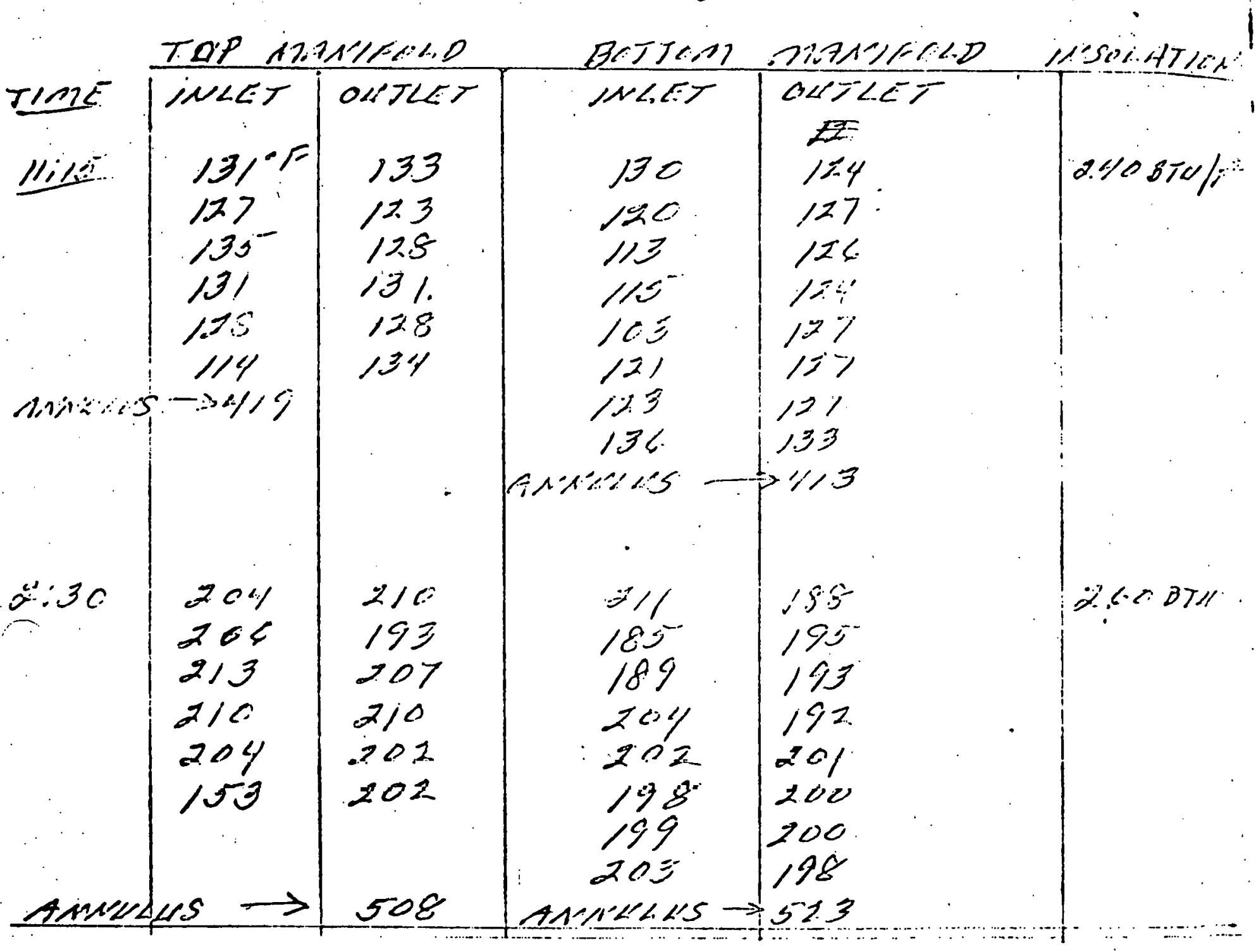

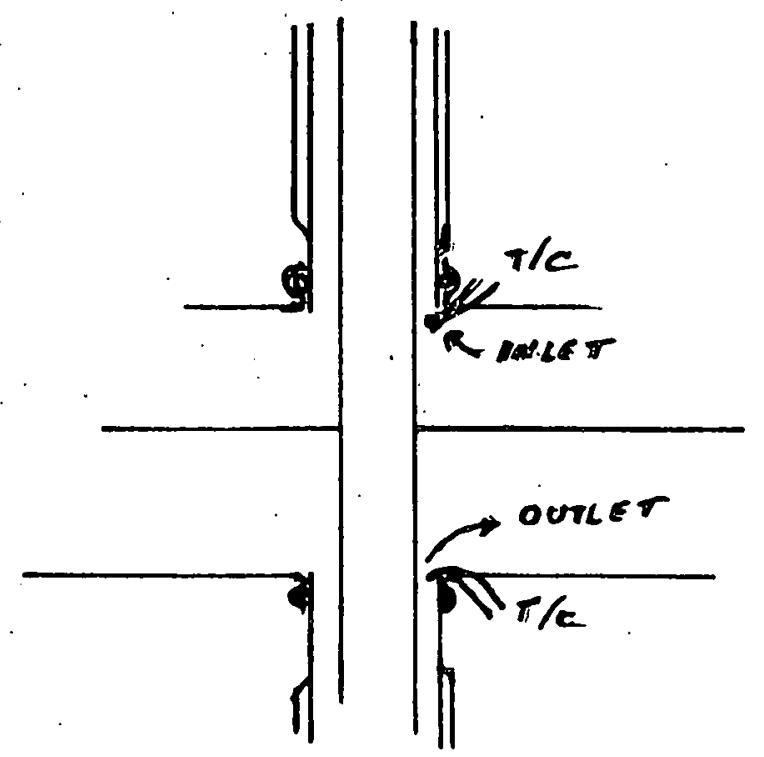

FIGURE 4.2./(b).

88 
AMBIENT TEMP. $=84^{\circ} \mathrm{F}$

口 INSOLATION

- lower tube anNulus

COLLECTOR TIME CONSTANT TUEES UNCOVERED X UPPER TUBE ANNULUS

AND STAGNATED FLOW AT 4 SCFM INTRODUCED

○ EXIT DUCT AIR TEMP.

INLET DUCT AIR TEMP. $\doteq 90^{\circ} \mathrm{F}$

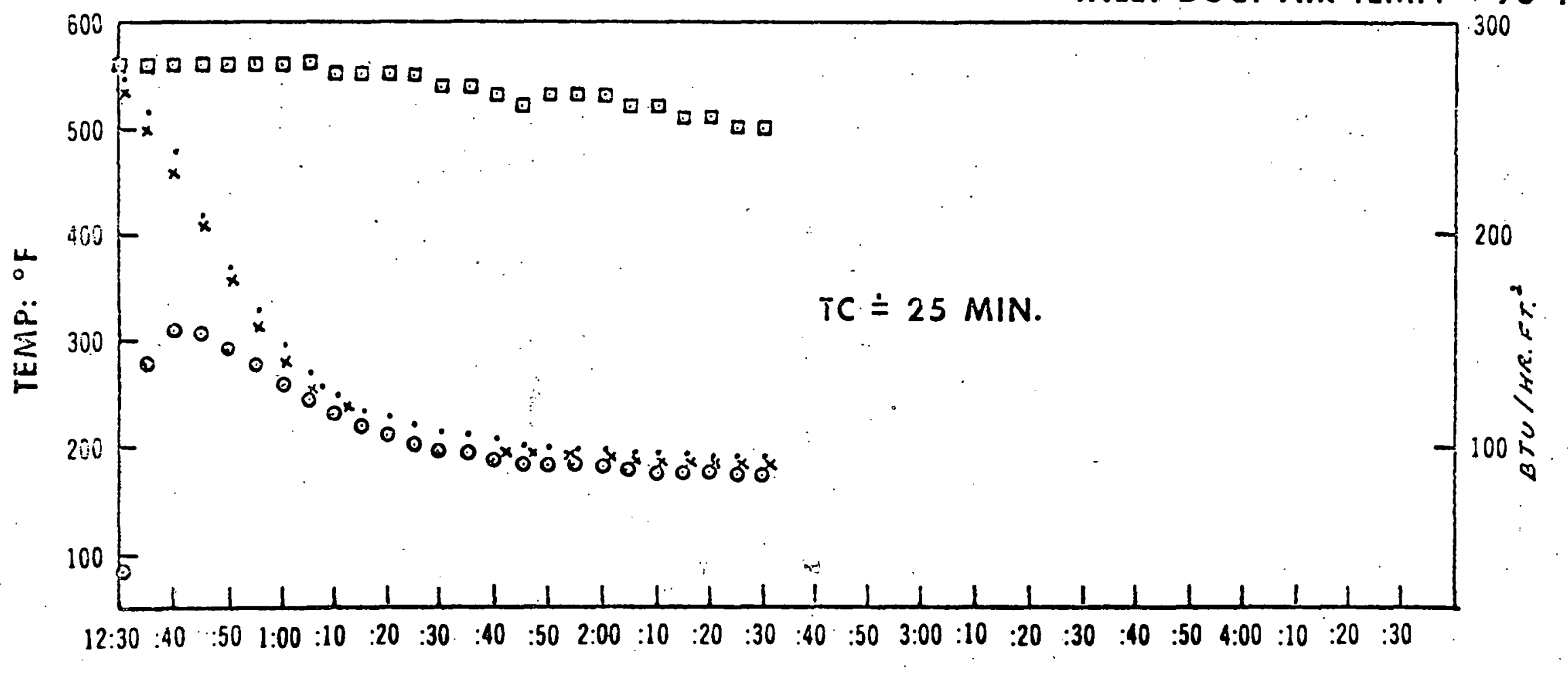

TIME E.D.T. 


\section{Intra-Company}

10

-

subject
R. Moan - Dev. Ctr.

Thermal shock Testing of Sunpak ${ }^{\text {TM }}$
CC: G. R. Mather - Dev. ctr.

F. H. Brown - Dev: Ctr.

B. R. Emch - Dev. Ctr:

\section{Introduction}

Sunpak ${ }^{T M}$ sunair collector tubes can reach stagnation temperatures of 600 $625^{\circ} \mathrm{F}$ under no-flow conditions. If air circulation is started in a stagnating system the inside surface of the absorber tube would be thermal shocked. The stresses generated in this type of thermal shock would be less than if water caused the thermal shock, due to the lower thermal mass of lhe alr and the lower heat txansfer film coefficient at the air/glass interface.

The purpose of this investigation was to develop an aix themal shock test for sunpak ${ }^{T M}$ sunair collector tubes, and to assess the thermal shock strength under conditions of maximum expected shock and abuse.

\section{Conclusions}

2.1. Sunpak ${ }^{T M}$ sunair tubes can withstand the maximum possible thermal shock attainable (stagnațion to ronm temperaturc air) even when severe defects are present in the glass.

\section{Test Procedure}

\subsection{Thermal Shock}

The collector tubes were heated with a calrod heating element enclosed In a one inch diameter aluminim tube. Tho calrod unil was placed inside the collector tube and the end sealed off with insulation. The tube temperature was measured and controlled by separate thermocouples placed at midpoint. .

After the control temperature had been reached (about 15 minutes), the collector tube was, removed from the heating fixture and placed in a verticle rack. 
Immediately an aluminum tube, identical to the feeder tube off a sunpak TM sunair air distribution system, was inserted into the tube. Nitrogen from a compressed tank was flowed through the feeder tube for five minutes. The temperature of the nitrogen was measured before the test and after'the five minutes.

Test glass temperatures were varied from $625^{\circ} \mathrm{F}$ to $700^{\circ} \mathrm{F}$. Nitrogen temperature was $70 \circ \mathrm{F} \pm{ }^{\circ} \mathrm{F}$. Nitrogen flow rates of $120 \mathrm{CFH}$ (Standard) and $360 \mathrm{CFH}$ ( 3 times standard-more shock) were used.

\subsection{Tube Scratching}

In order to create a condition where the collector tubes are more likely to break under thermal shock, severe chatter checks were intoduced on the inside surface as follows:

A No. 14 hardened sheet metal screw was fastened throurh a flat steel strip so that the end of the screw extended through the strip. After. sharpening the screw with a file, the tubes were scratched by running the tube over the screw at approximately 80 of the mid portion length of the tube. Six pairs of. scratches were produced axially, approximately equidistant.

\subsection{Pressure Testing}

Hydrostatic destructive pressure testing was performed on the tubes of 3.2 after thermal shock tests had been completed. A hand operated piston pumo was used at a load rate of about 100 psi per second.

\section{Results}

Table 1 summarizes the thermal shock test results. No breakage was encountered.

Pressure test of the five intentionally defected tubes, Nos. 4-8 gave an average failure pressure of 270 psi with a range of $250-300$ psi. 
Table 1. Thermal shock Summary

\begin{tabular}{|c|c|c|c|c|c|}
\hline \multirow[t]{2}{*}{ Tube $^{(1)}$} & \multirow{2}{*}{$\begin{array}{l}\text { Glass } \\
\text { Temp. } \\
\left(O_{F}\right)\end{array}$} & \multicolumn{2}{|c|}{$\begin{array}{l}\text { Nitrogen } \\
\text { Temp. (OF) }\end{array}$} & \multirow{2}{*}{$\begin{array}{l}\text { Thermal } \\
\text { Shock } \Delta \mathrm{T} \\
1\left(\sigma_{\mathrm{F}}\right)\end{array}$} & \multirow{2}{*}{$\begin{array}{c}\text { Nitrogen } \\
\text { F low } \\
\text { (CFi) }\end{array}$} \\
\hline & & Initial & Final & & \\
\hline 1 & 700 & 68 & 208 & 632 & 120 \\
\hline 2 & 700 & 68 & 256 & 632 & 120 \\
\hline 3 & 700 & 71 & 230 & $619^{\circ}$ & 120 \\
\hline I & 700 & 68 & 116 & 632 & 360 \\
\hline 2 & 700 & 71 & 117 & 629 & 360 \\
\hline 3 & 700 & 71 & 115 & 629 & 360 \\
\hline 4 & 700 & 71 & 243 & $\overline{629}$ & 120 \\
\hline 5 & 660 & 71 & 258 & 589 & 120 \\
\hline 6 & 700 & $69^{\circ}$ & 247 & 631 & 120 \\
\hline 7 & 625 & 70 & 245 & 555 & 120 \\
\hline 8 & 620 & 69 & 263 & 551 & 120 \\
\hline 4 & 700 & 68 & 142 & 632 & 360 \\
\hline 5 & 660 & 70 & 151 & 590 & 360 \\
\hline 6 & 700 & 69 & 143 & 63.1 & 360 \\
\hline 7 & 625 & 69 & 155 & 556 & 360 \\
\hline 8 & 620 & 68 & 152 & 552 & 360 \\
\hline
\end{tabular}

\section{Notes}

(1) Iubes 1-3 standard tubes, no abuse Tubes 4-8 defected tubes, see 3.2 


\subsection{Fire Safety.}

\subsubsection{Applicable Fire Standards.}

Applicable sections of NFPA 89M, NFPA 90A and 90B, MFPA 30, NFPA 31, NFGC 54-1, NFPA 25b, IIFPA 211 and ANSI/ASTM E-84 were reviewed for applicability to the Model SEC-601 collector. In addition, "HUD Intermediate Minimum Property Standards Supplement -- Solar Heating and Domestic Hot Water Systems, 1977 Edition" 4930.2 was reviewed for applicability. A review of the drawings and specifications of the Model SEC-601 collector was also completed. Experimental tests and evaluations were performed to evaluate qualitatively such factors as potential heat, rate of heat release, ease of ignition and smoke generation. The outside surfaces of the collector subsystem consist almost entirely of a metallic or giass material. Ali elements of the collector subsystem are mounted external to the roof (fire wall) of the building enclosure. The collector subsystem does not reduce the fire resistance rating of the roof assembly. A major or catastrophic fire condition would have to be reached before the collector components would reach ignition conditions. The heat transfer fluid is air and therefore does not contribute to a fire hazard condition.

\subsection{Protection of Potable Water and Circulated Air.}

\subsubsection{Growth of Fungi.}

Silicone base and zytel nylon materials, $\mathrm{K} 633$ glass and aluminum are the materials in contact with the air circulating in the Model SEC-601 collector. Attached Figure 4.6.4(a) and Figure 4.6.4(b) 


\subsection{4 (cont.d)}

are design handback data on silicone and zytel nylon materials. The data indicates the resistance of the material to the growth of bacteria, fungi and termites.

Rcview of items $4.3,4,3.1,4.6,4.6 .4$ successfully completed.
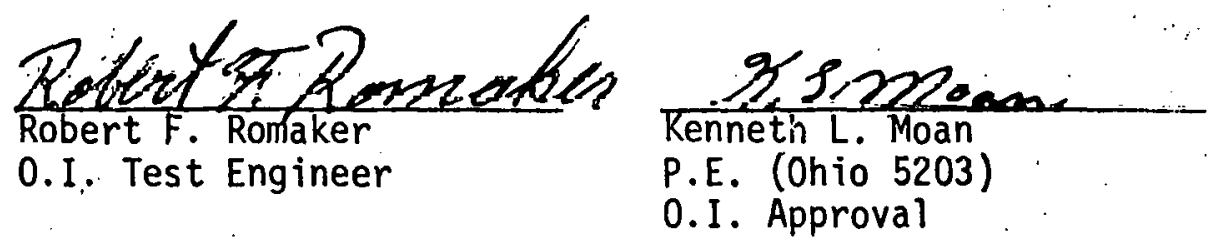

Qwirl e. Miller David C. MiTTer, Ph.D. SH\&G Certification officer
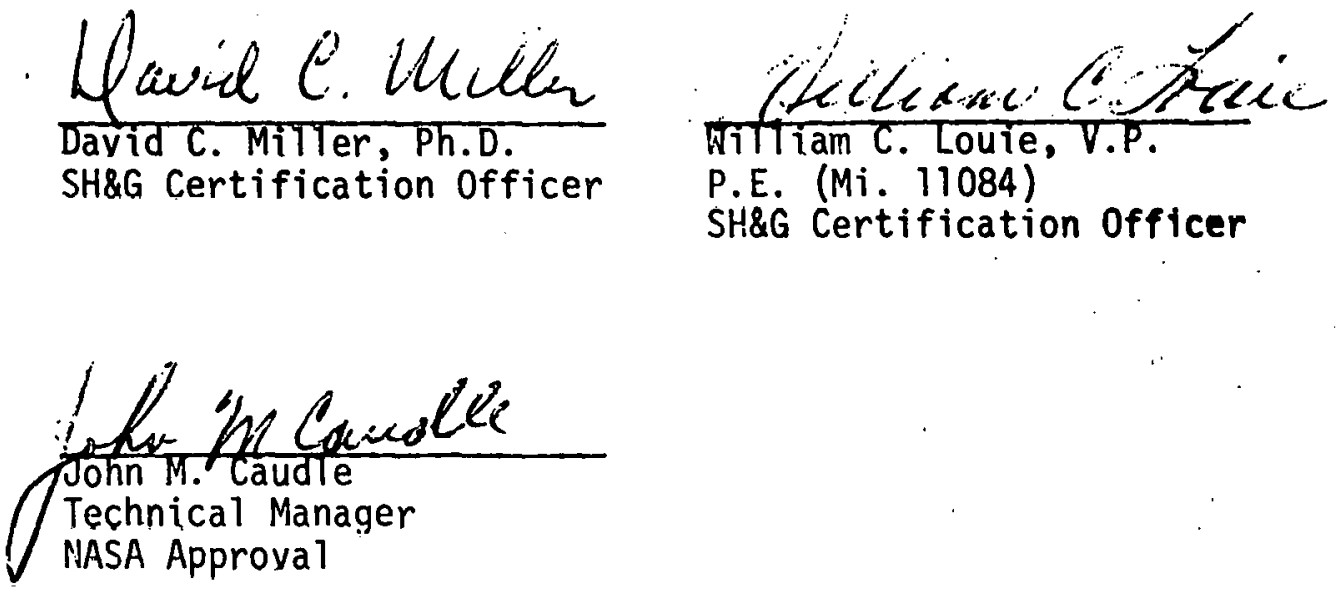


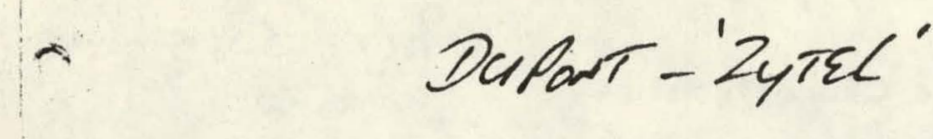

At temperatures in excess of $150^{\circ} \mathrm{F}$, however, certain specific lubricant additives may effect performance.

Test data on the behavior of "Zytel" exposed to these automotive fluids at elevated temperatures is essential to the success of the intended use. This matter is discussed in detail in an SAE Paper*.

Another approach designed to measure the suitability of "Zytel" in various environments involving exposure to automotive materials is discussed in a second portion of that same paper**. This describes how automotive parts were obtained and evaluated after extended in-use service. Copies of the SAE Paper can be obtained from your Engineering Plastics Sales office.

- Gasolines. "Zytel" nylons are outstanding in their resistance to conventional automotive fuels. "Zytel" shows an average weight increase of 0.57 percent and an average dimensional change of +0.009 percent after 270 days exposure at $73^{\circ} \mathrm{F} .\left(23^{\circ} \mathrm{C}\right.$.) to the following gasolines: Esso Regular, Esso Extra, Esso Golden Extra, Amoco High Test, Sunoco, Gulf Crest, Texaco, Mobile Premium.

- Acids, Bases and Oxidizing Agents. "Zytel" nylons are very resistant to alkalies even at high concentrations up to 40 percent. They are, however, rapidly attacked by strong mineral acids and/or oxidizing agents especially at high operating temperatures. Use in dilute solutions of acids or oxidizing agents under ambient conditions is often possible, but actual or simulated service tests should be conducted to ascertain the suitability of "Zytel" for the particular application.

- Soaps and Detergents. Tests conducted at $180^{\circ} \mathrm{F}$. $\left(82^{\circ} \mathrm{C}\right.$.) show that "Zytel" nylons have excellent resistance to standard detergent formulations such as "Tide", "Dreft", "Dash", "Oxydol", "Oakite", Calgon and Fels Naphtha soap.

\section{CHEMICAL RESISTANCE OF GLASS. REINFORCED "ZYTEL"}

The chemical resistance of glass-reinforced "Zytel" nylons is frequently superior to that of unmodified nylons. For a detailed discussion, see Section 11.

\section{TABLE OF CHFMICAL RESISTANCE}

Information on the resistance of "Zytel" to specific reagents is shown in Table 31 . Ratings of excellent, satisfactory or unsatisfactory are based upon property retention for test bars exposed to the specified concentrations of the materials for the indicated time periods and temperatures. Chemical resistance information in Table 31 is based on appearance and on retention of physical properties normally after drying to remove residual moisture and reagents.

Du Pont also has accumulated a large bank of information on chemical resistance of "Zytel" 10 materials not

* "The Suitability of 66 Nylon Resins for Molded Parts Involving Long-Term Resistance to Heat, Gasoline and Salt", Socicty of Automotive Engincers, Mid-Year Meeting, Detroit, Michigan, Ifay 18-22, 1970, Paper $\# 700485$.

**.".valuating the Effect of Extended Service in Automubiles on Parts llade of 66 Nylon and Acetal Homupulymer", Society of Automotive Fngineers, Mid-Year Meeting, Detroit, Michigan. Nay $18-22,1970$, Paper $\neq 700485$.
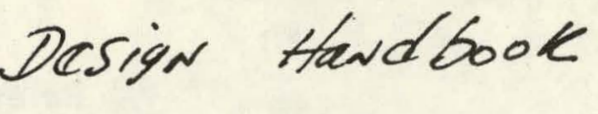

-1972 Eथ. PART 5066

shown in this Table and for many conditions not listed. Consult your Du Pont Engincering Plastics Sales office (see back cover) if additional chenical resistance information is needed.

\section{Bacteria And Fungi: Soil And Underground Conditions}

"Zytel" nylons have been found remarkably resistant to attack from bacteria, fungi and termites both in laboratory-type controlled tests and in burial tests.

Test specimens of "Zytel" 42 were buried at Landenberg, Pennsylvania for $3-1 / 2$ years in termite-infested soil. Examination after burial showed no attack by termites nor any apparent deterioration from fungi, insects or other biological agencies. It was concluded that "Zytel" was neither attractive to lermites nor readily utilized by fungi. Control specimens of pine wood showed heavy infestation with termites.

Two types of "Zytel" ("Zytel" 101 NC-10 and 211 NC-10) were tested microbiologically for their ability to support Salmonella typhosa growth, (food poisoning). The test proved that these samples would not support the growth of this bacteria.

Molded specimens of "Zytel" 101, 103, 105 and 63 were tested for resistance to fungi representatives of the following groups: (1) chaetomium globosum, (2) rhizopus nigricans, (3) aspergillis flavus, (4) penicillium lute um, and (5) momononiells echinata.

Test bars exposed for 28 days to active environments with respect to fungi showed no visual evidence of attack after cleaning and no loss in physical properties. Also, no changes occurred in molecular weight.

\section{Irradiation}

Among plastic materials, "Zytel" 101 is intermediate in its resistance to the heterogeneous radiation flux of an atomic pilet. Thus, "Zytel" 101 is more resistant than such materials as cellulose acetate and methyl methacry. late polymer, but less resistant that polyvinyl chloride acetate. During radiation, test bais of "Zytel" 101 initially show increased tensile strength with some loss in toughness. With progressive radiation, brittleness develups.

Furthemore, "Zytel" 101 is relatively resistant to the effects of gamma radiationtt. Tests on nylon film ( 66 nylon) made after exposure to 6 megarads of gamma radiation indicate essentially no ham to the material. On the basis of the study, it was concluded that 66 nylon could be considered as packaging of food subject to perservation by high energy radiation.

tThe United States Atomic Energy Commission ORNL-928, Sisman, O. and Bopp, C. D., June 29, 1951.

$\div$ Trasnansky, V. J., A shhammer, B. C., and Parker, M. S., SPE Transactions, July 1961 - Iffect of Gamma Radiation on Chemical Structure of Plastics. 
Q $1 \mathrm{~s}$ foert material, aificone rubbsi is oderless ind

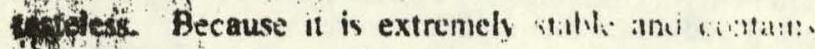

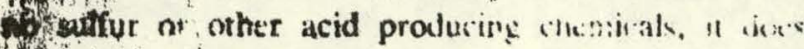

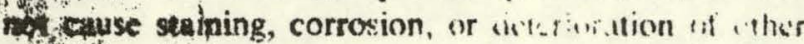
natifrials with which it comes in institct.

Nas;

P.

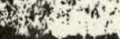

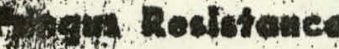

the $3: 3$

6. Whotery cured silicand rubber will not support the Whot of tungua. Samples of silicone rubber have bien 4of tuny tested ggaisgt the two major military speci-

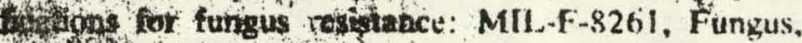
Worstabe $\mathrm{T}$-sts, Aeronautical and Associated $\mathrm{Ma}$ Wha, Gederal Specifonton For; and MIL-E-5272A,

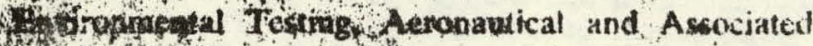

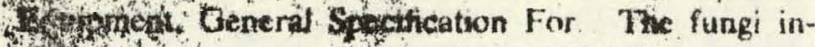

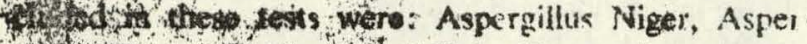

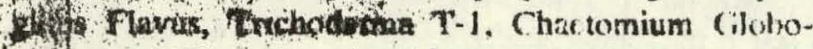
Sitho Penicilliun Luteum, Mennonieila Echinat:

is

$+28$

in

\section{Hifiótion Resistanse}

The thility of nilicone rubbet in asut tadiation lam.

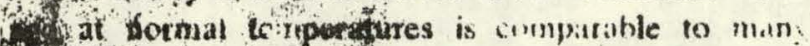

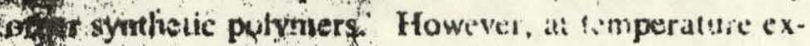

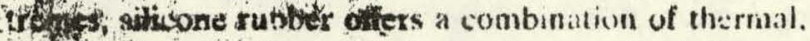
oxfetion, and radiation resistance not available in any (nft) polymer.

is tridiation resistance is nom:laliy defined by the

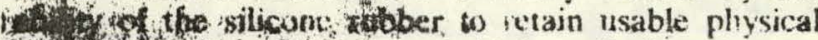
9. Writes after sxposure to high tadiation dosagc.

TH. silicone nibber reflects saysfactory resistance

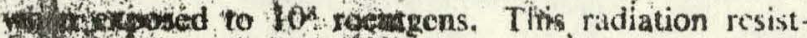
tol te otcedw that of TCE resin and is comparible 1 is or supertor to, throdastomers at room temperature. Av-ilable utata, was far, indicates a distunct radiation

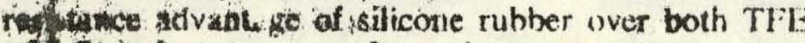
10 fituroeh stome:s at elevaled temperatures.

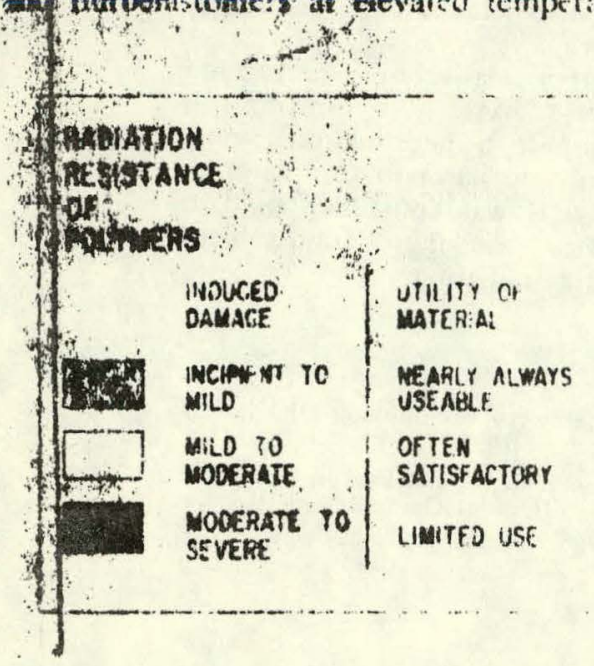

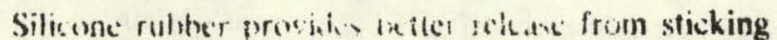
than anv ntis: nber thes : xample sif an application

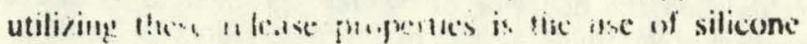
rubber toi $11 \%$ rollers wed in processing. sticky mascrials such at her polyethylenc and adtesives.

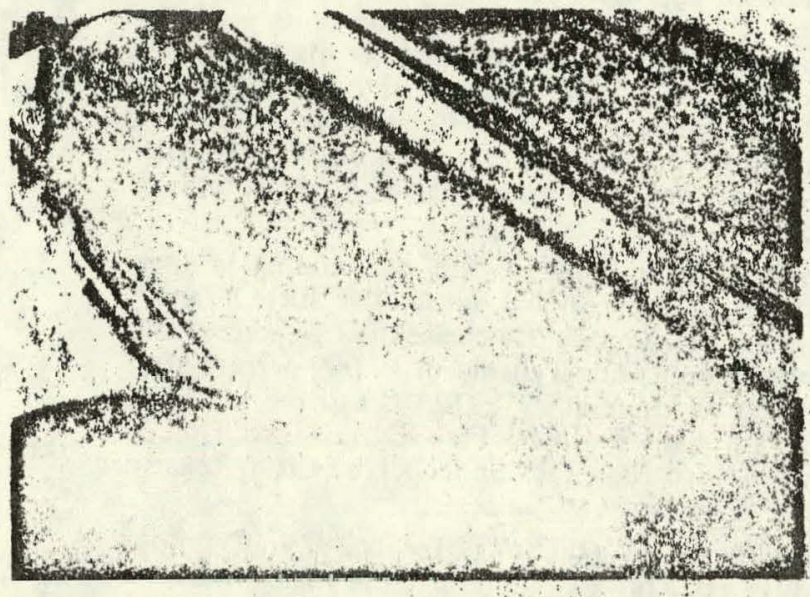

Mecause silicone rubber roflers previle excoltent

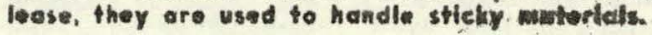

\section{Bonding Properties}

Whar properly applice! silicone rubher compounds viif tond and have great uscfulness as adhesives or sealants. Such bomals are tough and remain llexible at is mpertitiltes up to $i(0)$ li and can be made to atmost all metals. glass, ccramics, most rigid plastics, and, of course, silsone rubber itself.

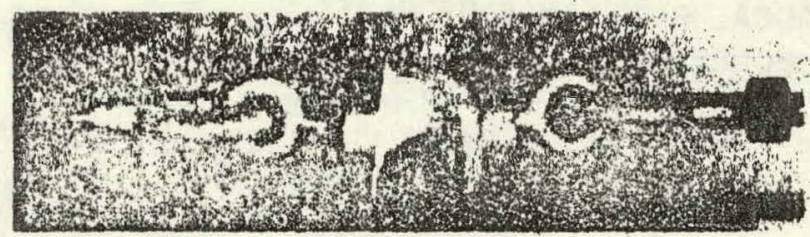

The bond of silicene self-bondime rabbers oxeoods the then pensile strangth of the rubber itself. Netice the rusber yieldisg befor the bends.

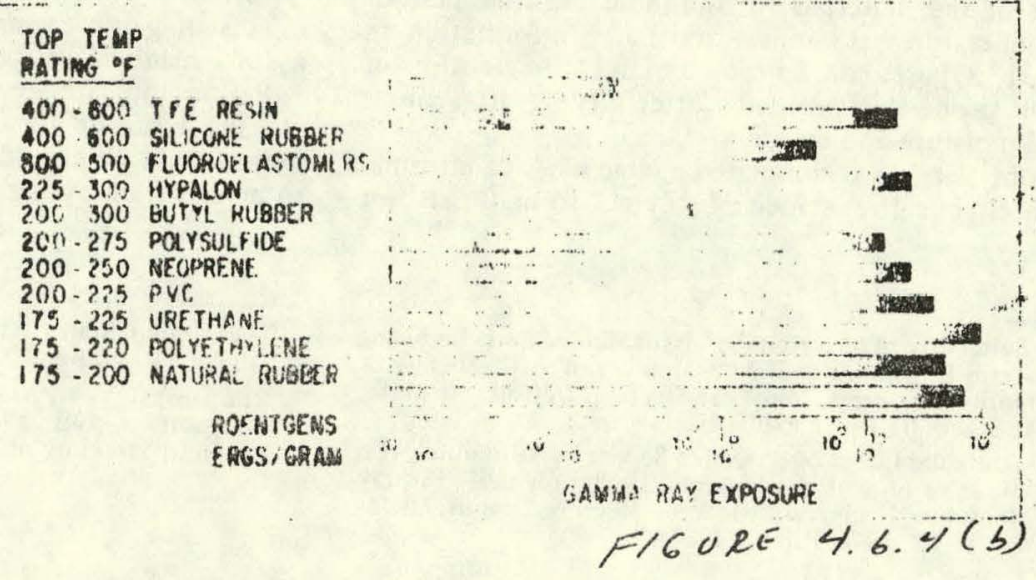




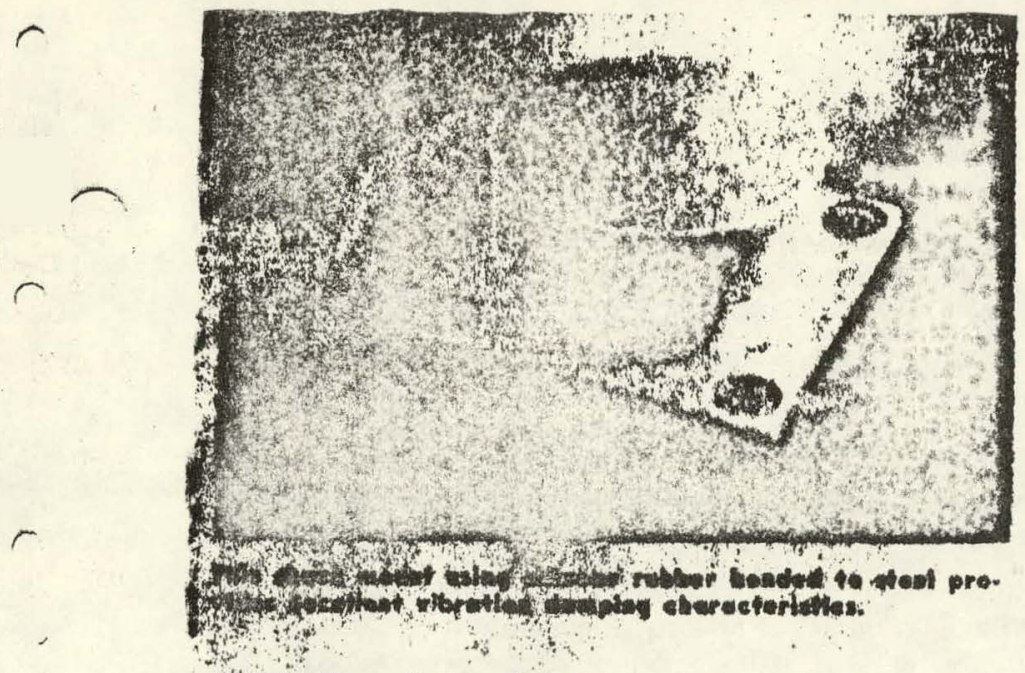

\section{Wration Dampine}

Af siliowize rubber has the ability to absorb encrgy over 14. wide renge of fregueses and over a wide tempera. vo smage, its exceltet elastic and dampening proper1. 5onile it deally durted for use in vibration control

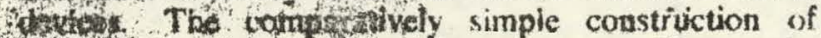
Whatusn sontrol novintiggs designed with silicone rub4. together with th proven durability of the nibber. 1- the maxinnus in long term reliability.

is ${ }^{2}$ transmissibility and resonant trequency of 1.

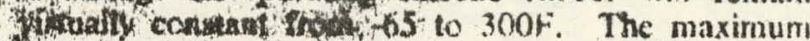

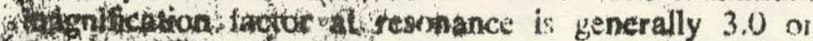
20 for of lower finperatures, and 3.5 at $300 \mathrm{~F}$.

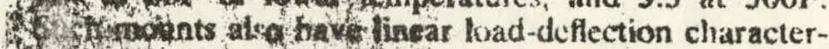

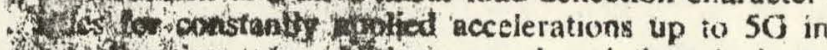

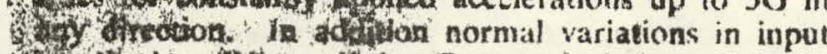

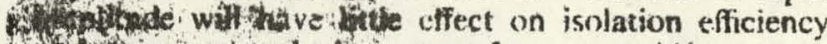
Who no marked resonant frequency shift.

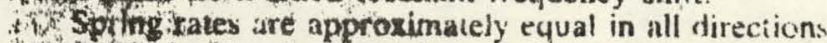
and ofigh high damped chaxacteristics yicld a tran:- issidsilty curve that is smonth it the high frequency thes. It is unttoken by spring surges or high fri... Whency harmonios which might damige the meuntei tevipionent.

"Womping charactetistics incriast at an exponcintia! bote and provide gentle bottoming under shock cim Atons, These moantings cushion is load gradually. and are capable of large deflections with a non-linear soping rate. Repeated test shncks of $1.5 \mathrm{~F}$ do not reiluct: follation efticiency, and the mounts will withstand 31 (); shock te pulses without failurc.

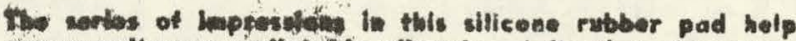

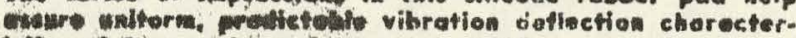

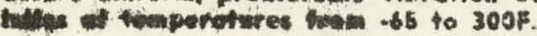
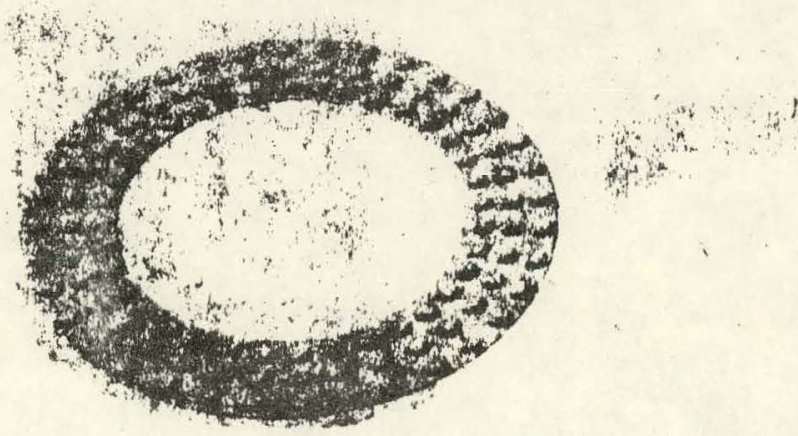

\section{Oxone and Corona Resistance}

The ozone resistance of silicone rubber approaches that of mica. Unlike Huoro-carbon matcrials, such as Poivtetrafluoroethyiene resins, which have good ozonerecistance: but degrade rapidly when subjected to corona, ilicone tubter al:o has excellent corona resistance

To determine the resistance of silicone rubber to high voltage gradients, samples of \#20) AWr, wire with a 3,64 inch wall of insulation have been subjected to a 10,000 valt potential for 100 hours at a terntperature of $500 F$. There were no signs of stress crucking or corona erosion at the conclusion of this test. Under the same conditions organic rubber insulations fail within a few minutes, even when the test is conducted at room temperature.

Tests also show that organic rubber is badly dam. ayed after being subjected to a stress of $200 \mathrm{volts} / \mathrm{mi}$ for 30 minutes. Even after 12,000 hours silicone rubber insulated wire is unaffected by a stress of 200 voits/mil.

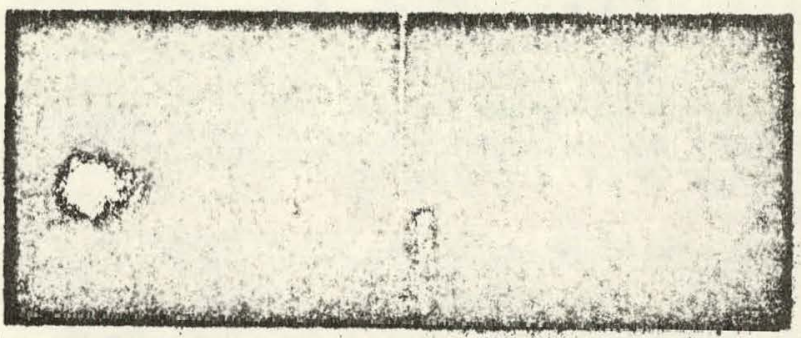

Sllieone rubber is virtually unettuef od by ewrowe.

\section{Resistance to Weothering}

silicone rubber resi ts the deteriorating effects of sunlight, owone, and gases which cause weathering. Inhercistly "nler repellent, silicone rubber is not affected by nowil operating conditions. Very dry conditions and hus humidity will not leach, dry out, or affect siljcone rublict in any way, at any temperature extreme founcl in nature.

Silicine rubher alao has gond resistance to deterioratin: ant ilt found in sin water: chloride, suffate, nitritt, arri hydrogen ion. Surface water which may have leeched minerals, acids, bases, and salts from the soil nesmal!y has no detrimental effect on silicone rub. her Silicnne rubber will effectively resist the concentritions of such material, found in surface water.

\begin{tabular}{|c|c|c|}
\hline & \multicolumn{2}{|c|}{$\begin{array}{l}\text { SILICONE RUBBER RESISTANCE } \\
\text { TO CHEMICALS CCMMMONLY FOUNO IN SOLL }\end{array}$} \\
\hline & Chemicei & Resistance \\
\hline & $\begin{array}{l}\text { Hydrochlore } 3 \% \\
\text { Phosphoric 10\% } \\
\text { Sulf } 10 \% \text { it: } 10 \%\end{array}$ & $\begin{array}{l}\text { Good } \\
\text { Good } \\
\text { Good }\end{array}$ \\
\hline Base. & $\begin{array}{l}\text { Codium Hydroxide } 1 \% \\
\text { "otatsium Hudros do } 1 \%\end{array}$ & $\begin{array}{l}\text { Good } \\
\text { Good }\end{array}$ \\
\hline pain & 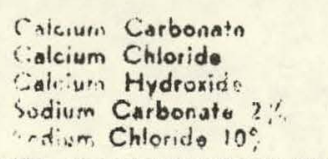 & $\begin{array}{l}\text { Good } \\
\text { Good } \\
\text { Good } \\
\text { Good } \\
\text { Good }\end{array}$ \\
\hline
\end{tabular}


sit.

\section{OZONE RESIS IANCE}

Silastis silicone rubber, wher: tested fur resistance to ozone.

thows exceliont stability. Atter both static and dynamic tesung for

periods of $2,4,6$, and 8 hou:s, tómples tiad so significant change

in durometer nardnese, tensile gstrength, or olongation. Under a thragnification of 10, no cracking or

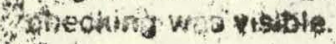

*in.

* Tha tests forbued pretemetures of ASTK D 518 and ASTM D 1149 with took modifications to match the tortstanding properties of Silastic Whatomiss. As specilled in

ASTM D 518, specimens were

whitichid 20 percent However, in

zedcition to fils siatic condition.

doyrratile test w ongated

s socimeris 25 partart in a cycle of

- Elstotorohos por minuta This

Whering it tha rubber more atfected

by ozdre, would wosult in the rapid

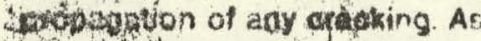
whie ch no cracking os checking iscoutrive

Otherhest modificatiant cancern tost method ASTRE D Pring Part $C$. under pracedure, spacitia a conceratiation of 25 parts of $07 \mathrm{C}: 3$ per 100 miltion parts of air. Arid for Hoflede dicone rubber, this was Increases of to a concentration of 4. 0.000 pants of ozone. Part D Fhy shes that a temperature of $32 \mathrm{C}$ 1ndy El viged for elestomers with tow rosistance to vaone tracking orda shat $49 \mathrm{C}$ is satisfaclory for

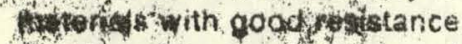
Sifastic rubber tested successtilly $\ln _{7 \rightarrow} \mathrm{C}$

\section{RADIATION RESISTANCE:}

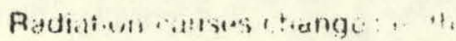

prost: :at, of sincilc rubuer

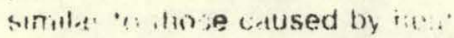

aging $A$. an lota rudiate.i dont

is incieasend. hardriess of ine ruter increases; rensi't. strength :11; increaso al first, but later ser renst's sharply: erorigaton decrensers

These direct affects of raciattin are proportional to the total ameunt of radiation level--as long as the radiation loves is low or mocterat. However. with high radiatic: leveis. the heatrig effects cause additionai changes:

Figure.15 shows the raciation drise that is required to retucis the elongation of two sumples if Silastic rubber of ati absoldin: level of so percant. Ciata i:. Given for radiction: exposiste to : cobalt-jo sourco at room temperiatute altu at $200 \mathrm{C}$ ihe level of 50 procent efungation $i$. arbitranly usad as the test eimpoint bocause, for many applicatichs; this is the minimum amount of. rubberiness iha! all , ilestomer bint have and still be us iul. Of course. static seals and similar produrt. might remain serviceable at much lower leveis of eiongation

FIQURE 15. Andiation required to reduce - lengation of two samplis of silasitc silicone rubber to an absolute value th 50 perceni
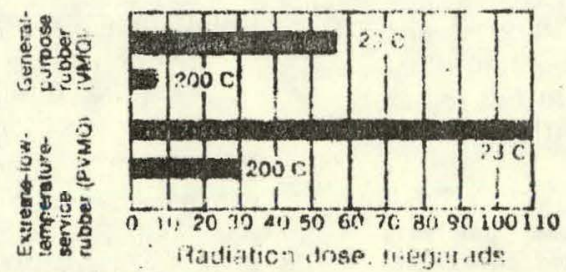

\section{FUNGUS RESISTANCE}

IV!s, untoer is ved in any warm ran.: is worment, its properties

wust rasist attack by mold or urigus Aithough Silastir, ruboer is tiot uhifungicidal it is not a nutrien: ior flung, nor is it adversely" atocted by tungus or mold.

With inst prusedures described in 005? 72 ? (USAF), several classes of Militaty Specification MIL-E.-cilicone rubber were exposed to chaelomium globum, asperynlius viriel aspergitlus lurrels po'vesllium luteni, and fusanum moniliforne. None of thes: micro-organisms deteriorated the specimens

In anotiner test, Silastic rubber samples: wite buried in 5 inches of warm (28 C) molst soil for 6 weeks with no evidence of microbial attack.

In a thure 'ost. samples were sprayed with a mixed spore suspensit. in of fungi and thon niaced in is iropical test chamber is 37 : $40: 00$ percent relative hurrisiv. ri he was attacked by iritdrow. 
ASIM

Designation

for Fypent

SII A.S TiC

tiritber

MO

VNC

PMQ

$\checkmark M Q$

Wh:

W.

कर

$+2$

.

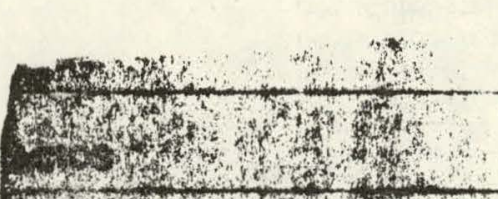

ingrsicy

indentuns

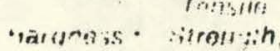

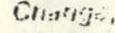

Vuluitie nerorat per ent percent

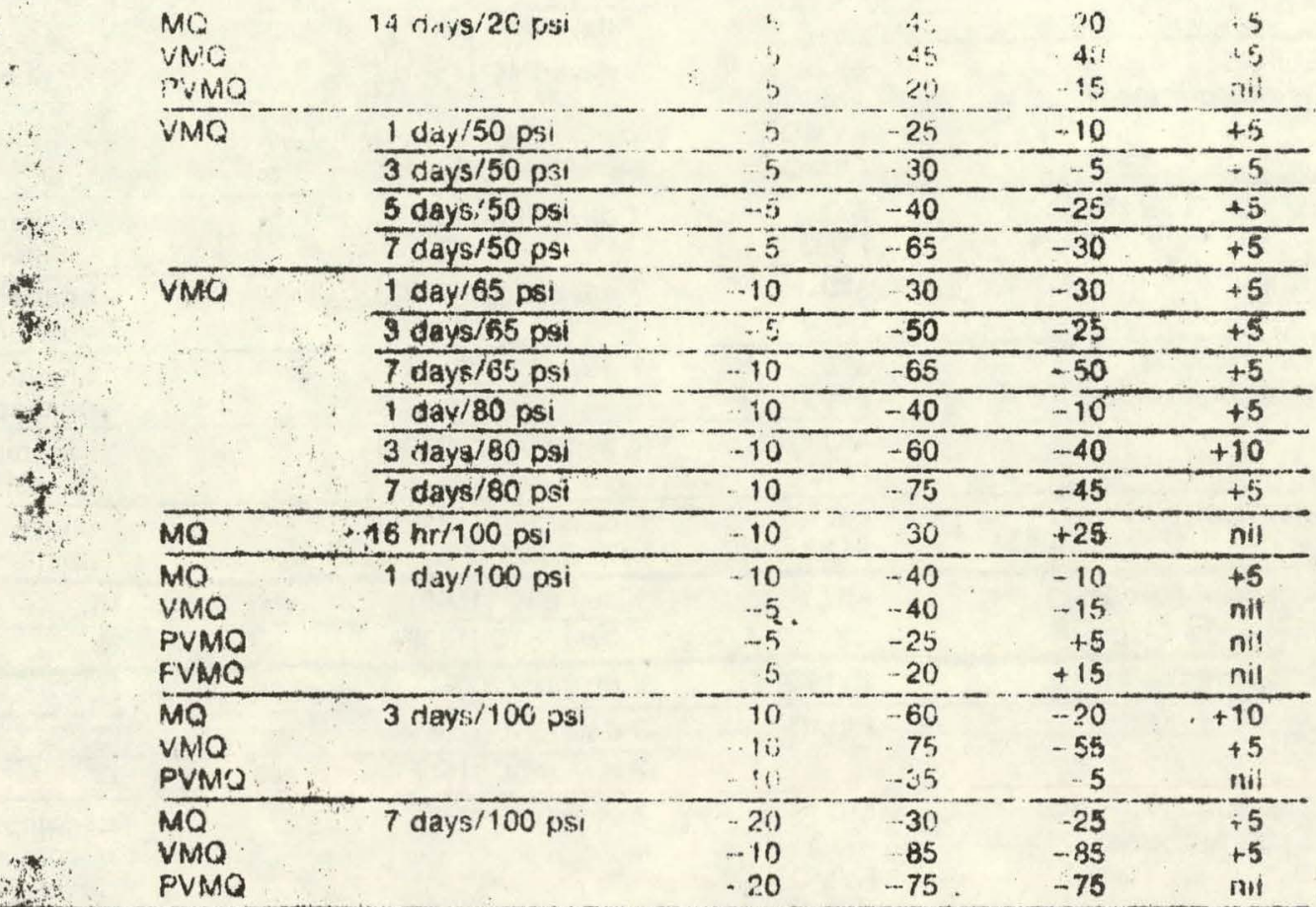

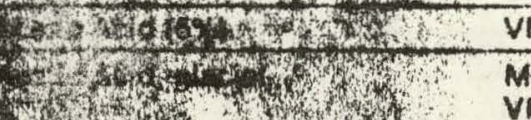

$\begin{array}{ll}\text { VMQ } & 7 \text { days } / 24 C(75 F) \\ \text { MQ } & 7 \text { days } / 24 C(75 F) \\ \text { VMQ } & \\ \text { PVMO }\end{array}$

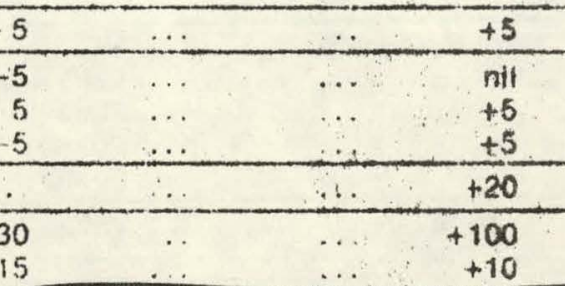
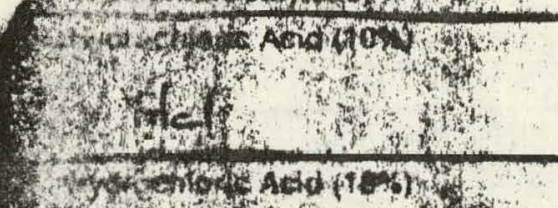

ME FVMO

VMO $\frac{2 \text { days } / 24 C(75 F)}{1 \text { day/100C (212F) }}$

FVMQ

MQ

VMO

PVMO

FVMQ

her.

FVMO 3 days/24C (75F)

3 days/65C (150F)

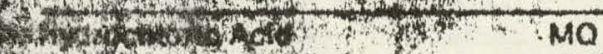

VMO

7 days/24C (75F)

$-15$

nil

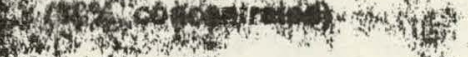

PVMQ

FVMO

PMQ $\quad 9$ days $27 \mathrm{C}$ (8OF)

No 7 days $/ 24 \mathrm{C}$ ( $75 \mathrm{~F})$

VMO

PVMAO

FVMQ

$-5$

nil

nil ... nil

...

nil

35

$\begin{array}{llll}-5 & \ldots & \ldots & +5\end{array}$

5

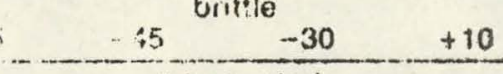

deternrated

\begin{tabular}{|c|c|c|c|}
\hline $\mathrm{mll}^{\prime}$ & & & +10 \\
\hline nif & & .. & nil \\
\hline nii & & & lin \\
\hline nii & 10 & -5 & nil \\
\hline
\end{tabular}

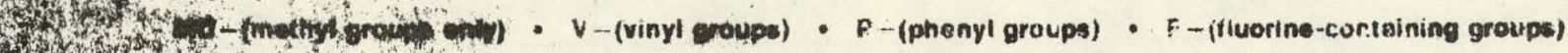


EVMO

that

fithitidicid

MO

3 days $/ \angle 4 C(7, F)$

days 65 C (150)

VMQ

days $/ 24 \mathrm{C}, 17 \mathrm{sF}:$

\begin{tabular}{|c|c|c|}
\hline $\begin{array}{l}\text { Hotules.s } \\
\text { Ghangi. } \\
\text { point. }\end{array}$ & $\begin{array}{l}\text { Strentiglo } \\
\text { revanige } \\
\text { heriztll: }\end{array}$ & $\begin{array}{l}\text { Eingation } \\
\text { Change } \\
\text { perrent }\end{array}$ \\
\hline
\end{tabular}

tis oridg

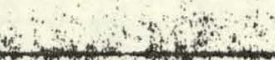

PVMA

FVMO

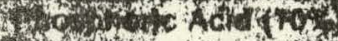

$M Q$

$P M O$

MQ

PMQ

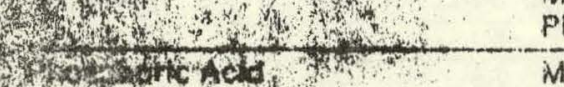

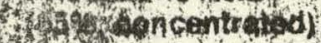

W.

MQ

MD

PMQ

MQ

PMO

$\frac{.5}{10}$

$\frac{15}{5}$

periant

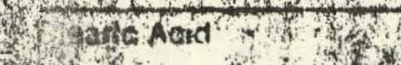

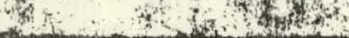

$M Q$

6h $\mathrm{SO}_{4}$

(Acidrean 3 .

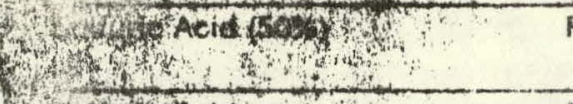

Wh 1 Croigs

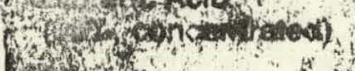

W 13

$+2$

W.

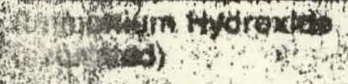

t.

13

- ovidonides

$\frac{4}{3}+3$

Hothoturated

a 3

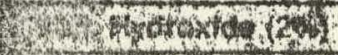

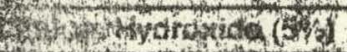

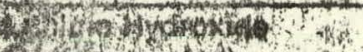

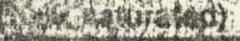

4 Crith thers

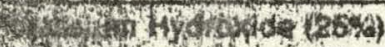

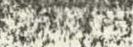

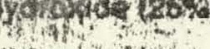

2.

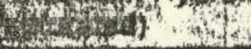

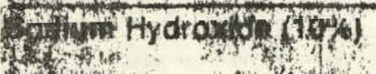

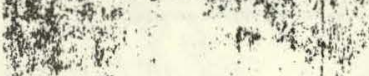

Kon

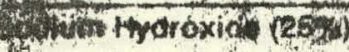

MO

VMQ

FVMQ

PVMQ

PVMAQ

FVMQ

$\frac{\frac{1 \text { day/83C }(180 F)}{7 \text { davs'b3C }(180 F)}}{2 \text { hri } 93 \mathrm{C}(200 \mathrm{~F})}$

7 ady 8 in

7 days/24C (75F)

7 days $/ 100 \mathrm{C}(2125 \mathrm{~F}$

7 days $124 C$ (75F)

7 days $/ 100 \mathrm{C}$ (212F)

5

nil

froor

brittie

$\frac{-10}{-3 i}-\frac{5}{-5}$

$\frac{-30}{-30}$

$1 \quad-40$

30

$+5$

unaiferted

unatfected

unaffected

unaffected

in affected

dissolveri

dissolved

$\begin{aligned} & \text { dissolved } \\ & \text { dissolved }\end{aligned}$
unaffected
unaffactar

unaffectery

$\frac{n \text { nil }}{\text { nil }}+\frac{10}{n+5}$

$\frac{10}{25}$

$-5$

$25-\frac{18}{20}-\frac{15}{-5}$

5

$\frac{-5}{35}-\frac{-5}{-15}$

decomposed

decomposed

decomposed decomposed

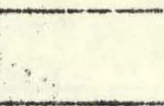

MQ
VMO
PMO
PVMG

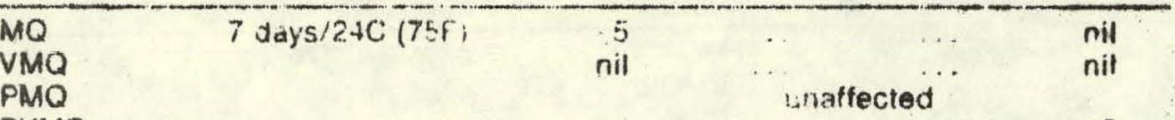

\begin{tabular}{|c|c|c|c|c|c|}
\hline $\begin{array}{l}\text { PVMQ } \\
\text { FVMO }\end{array}$ & & $\begin{array}{c}n+1 \\
-5\end{array}$ & 45 & -5 & $\begin{array}{l}+5 \\
+5\end{array}$ \\
\hline VMU & 1 dayi $149 \mathrm{C}$ (30uF) & 5 & $\cdots i 5$ & -10 & +5 \\
\hline
\end{tabular}

政

\begin{tabular}{|c|c|c|c|c|c|}
\hline VMa; & $1 \mathrm{day} / 149 \mathrm{C}(300 \mathrm{~F})$ & nil & 25 & -10 & -5 \\
\hline VMD & 1 day'149C (300F) & 10 & .70 & ntit & -35 \\
\hline $\mathrm{VMO}$ & 1 day $149 \mathrm{C}$ (300F) & & & & \\
\hline
\end{tabular}

\begin{tabular}{lccccc}
\hline VMQ & 1 day/744C (30OF) & +5 & -20 & -15 & 5 \\
\hline MQ & 7 days/83C (180F) & nil & & $\cdots$ & +5 \\
PMQ & & -5 & & -1 & nil \\
\hline VMQ & 1 dayi $149 \mathrm{C}(300 \mathrm{~F})$ & 20 & 4 & -10 & 10
\end{tabular}

MO

VMQ

7 days/24C(T/SF)

5

PMQ

FVMQ

FVMO

$\mathrm{MO}$
$\mathrm{PMQ}$

7 days $/ 83 \mathrm{C} .(180 \mathrm{~F})$

5

$-5$

5
$-45$

$\begin{array}{ll}\ldots & \text { nil } \\ \ldots & \text { nil } \\ \ldots & +5\end{array}$

nil
nil
+5

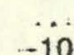

5

$-10$

nil

-

5

.

nil
10




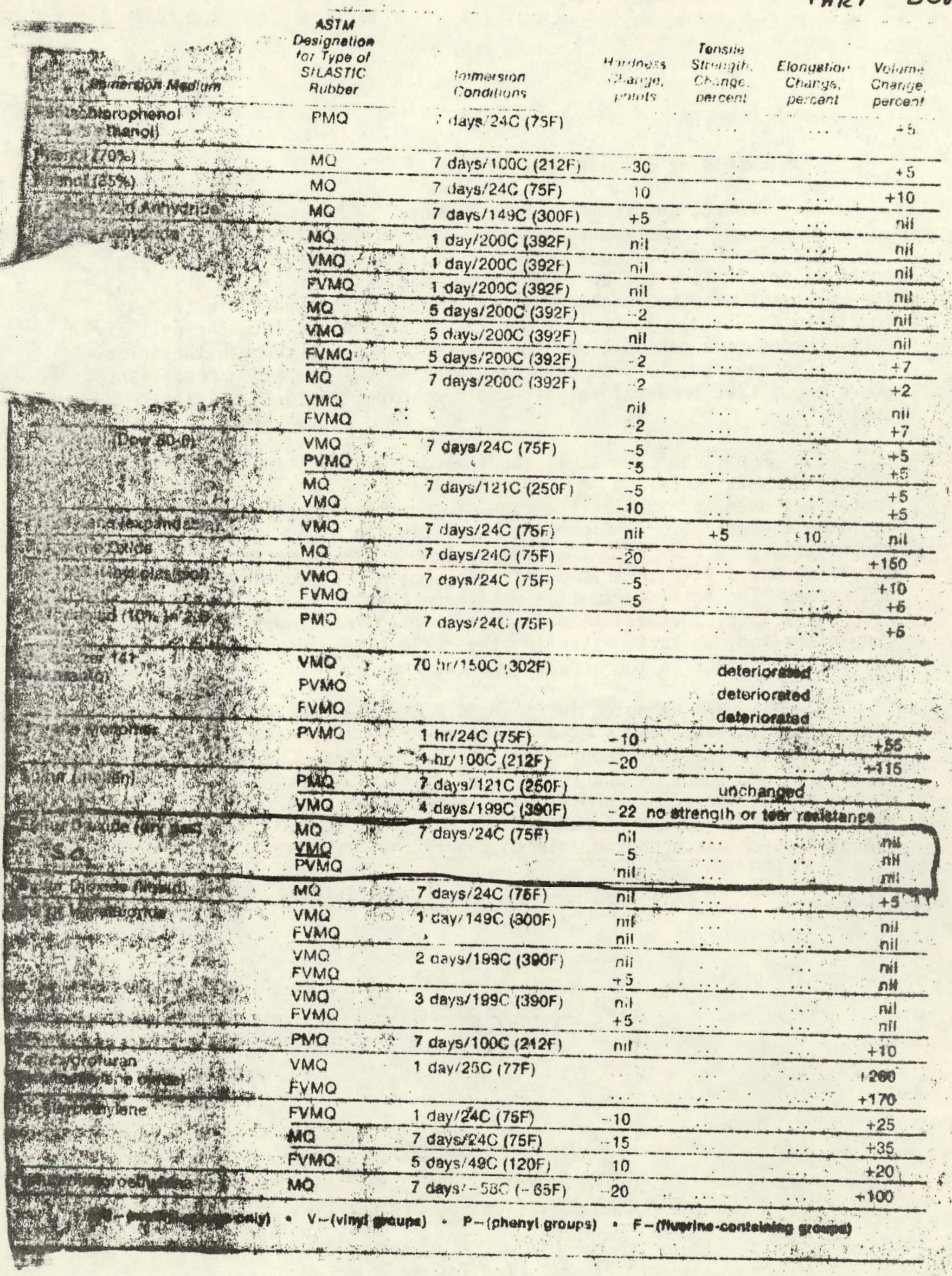




\subsection{Excessive Surface Temperature.}

4.7.1. Protection from heated components.

The Model SEC-601 collector was set up for thermal cycling tests. The air flow set up is shown schematically in Figure 4.7.1.(a). The collector was instrumented with temperature sensors as indicated in Figure 4.7.1. (b). The collector air flow path was into the exit air duct, through the manifold and tube elements and out through the inlet duct. The reverse air flow path simulates actual operating conditions where a positive temperature gain would be experienced from inlet to outlet.

A portion of a strip chart recorder indicating the sensed temperatures is contained in Figure 4.7.1.(c). A dual element electric heater was used to minimize the rate of change of the heated air flowing into the collector. Element 1 was activated at cycle time, $t_{0}$, the second after one hour into the cycle. Both elements were shut off after two hours into the cycle allowing ambient air to cool down the collector. The total cycle time was three hours. It will be noted in Figure 4.7.1.(c) that all temperatures were approaching steady state conditions and, in fact, extending the cycle time did not result in an appreciable change in the sensed temperatures.

It will be noted in Figure 4.7.1(c) that no exposed surface temperature exceeded $100^{\circ} \mathrm{F}$ at an inlet air flow temperature of $325^{\circ} \mathrm{F}$. Couple No. 9 senses the temperature at the interface between the glass cover tube and the silicone rubber seal. This surface is not exposed during normal operating conditions. In addition, scveral of the personnel explored the collector surfaces by touch; no surface could be detected which was uncomfortable to the touch.

Review of Items 4.7. and 4.7.1. successfully completed.

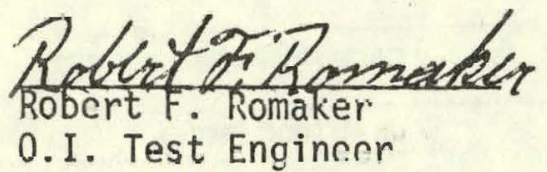

Kenneth L. Moan

P.F. (0hio 5203)

0. I. Approval

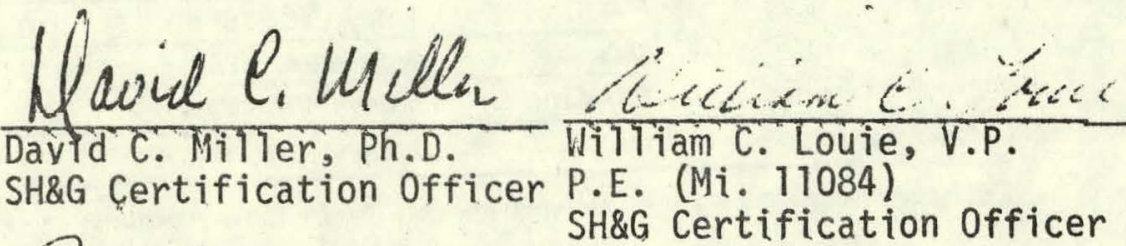

DavPd C. Miller, ph.D.
SH\&G Certification Officer P.E. (Mi. 11084)

SH\&G Certification Officer

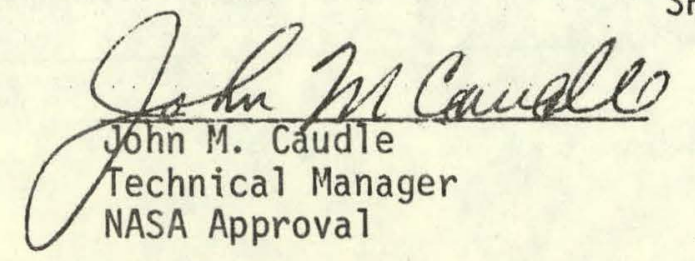



THERMAL CYCLE TEST SCHEMATIC SURFACE TEMPERATURE MEASUREMENTS

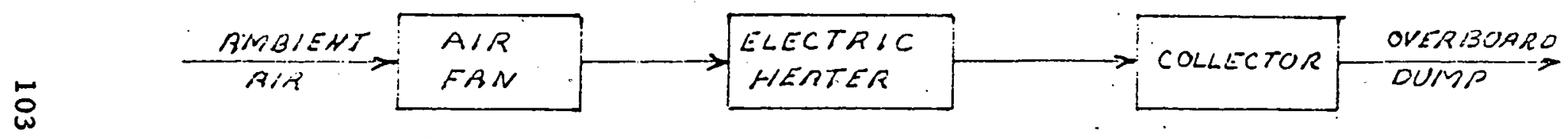

FIGURE 4.7.:(a) 
COLLECTOR AIR AID SURFACE TEMPERATURE SENSOR LOCATIONS

5

$\operatorname{Con}_{\text {AMBIENT }}^{A}$ 


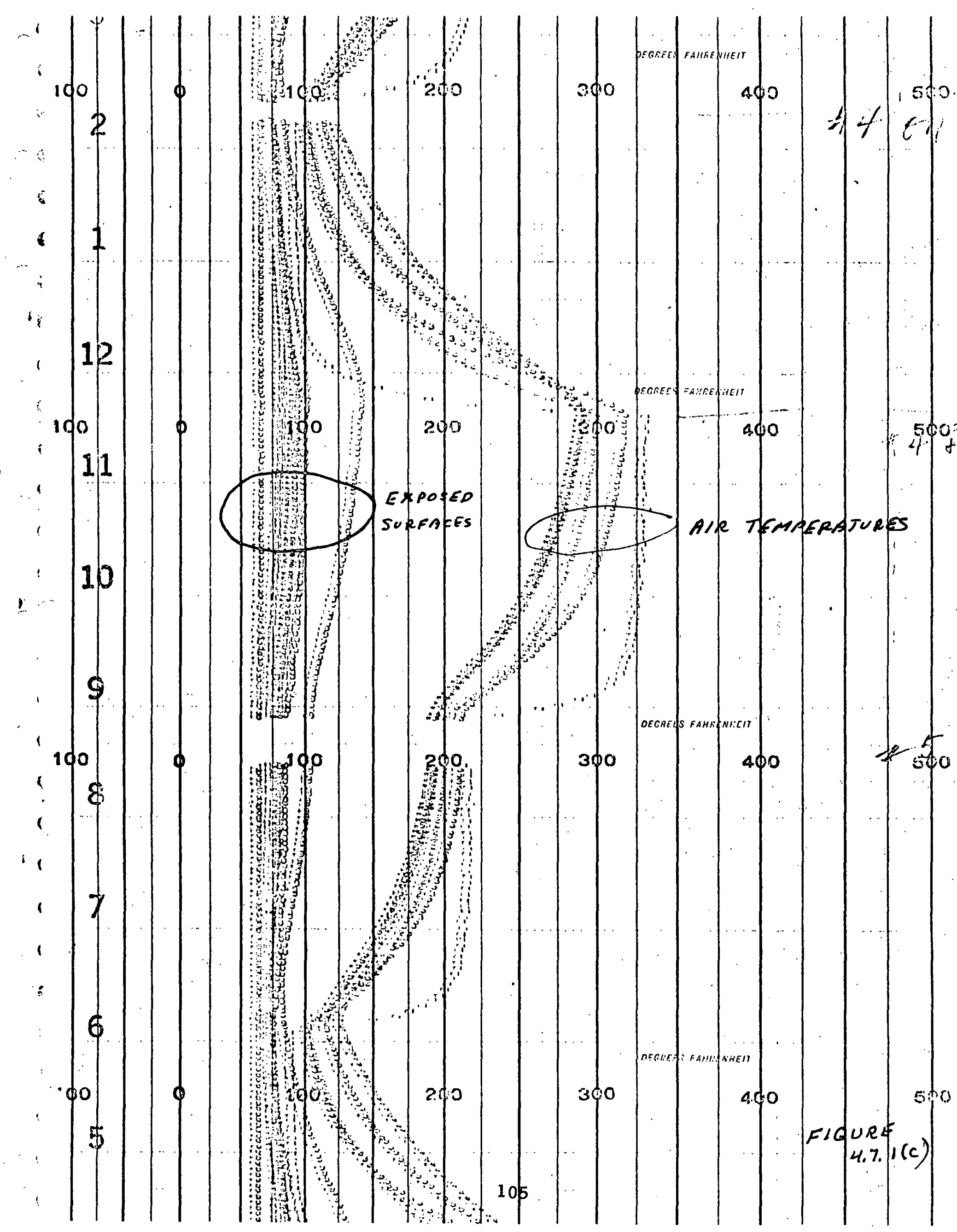




\subsection{Effects of External Environment.}

5.1.1 The capability of the Model SEC-601 collector cover material and wavelength selective coating to meet the solar degradation criterion have been evaluated by a combination of indoor accelerated life testing and long term outdoor exposure tests. The indoor accelerated life testing emphasized the evaluation of the long term stability of the wavelength selective coating and the vacuum. The tests and data have been reported under Section 4.2.1, previously submitted. The results of seventeen (17) months of outdoor exposure of the ERDA collector array are presented in Section 5.3. A review of this section verifies the capability of the collector components to withstand extended outdoor exposure without degradation which would adversely affect the capability of any component of the collector to perform its intended function.

As further evidence of the long term capability of the collector components to withstand outdoor exposure under stagnation conditions, collector components were subjected to outdoor exposure at the Desert Sunshine Exposure Tests, Inc. facility starting in August, 1976.

Figure 5.1.1(a), sheet 1 , contains a record of the stagnation temperature reached by a standard production liquid collector tube element In August, 1976. F1gure 5.1.1(a), sheet 2, indicates the stagnation temperature reached as a function of solar time on June 24,1978 . An indication of the level of solar radiation is also given for each test day. Because of instrumentation difficulties, the solar radiation listed is not that existing in the tilt plane of the test rack. The test rack tilt angle was changed monthly to correspond roughly to the plane in which the solar radiation 


\section{1 .1 (cont.d)}

would be normal to the test rack during the month. A review of the data indicates no significant change in the stagnation temperature reached and therefore that no degradation to the wavelength selective coating or vacuum has occurred after essentially two years of continuous outdoor exposure to the maximum solar radiation condition with no cooling fluid flow through the collector element. The test requirerients of Section 03 were exceeded by a factor of four with no evidence of deterioration in performance or change in characteristics of the wavelength selective coating. The production process for applying the wavelength selective coating, evacuation, tip off and getter material and flashing are identical for the liquid and air SUNPAKTM collector tube elements. Therefore, the Model.SEC-601 collector tube elements meet the criterion of this section by similarity. An extended outdoor exposure test has been initiated for the Model SEC-601 components. The first record of the stagnation temperature of each of the tubes is contained in Figure $5.1 .1(b)$

\subsubsection{Airborne pollutants.}

The capability of the components of the Model SEC-601 components to withstand exposure to airborne pollutants has been evaluated by similarity to the liquid SUNPAK ${ }^{T M}$ collector materials and moderate exposure testing of the Model SEC-601 components at Desert Sunshine Exposure Tests, Inc. Figure $5.3 .1(\mathrm{a})$ contains a listing of the liquid SUIPAKTM components with outdoor exposure test results from August 10, 1976 to June 27,1978 . Figure 5.1 .3 (b) contains a definition of the ranking 
applied to the physical inspection of the components. The rack on which the components are mounted is south facing. Its tilt angle is adjusted once a month in order to cause the solar radiation to be essentially normal to the rack during the month's test period.

Figure 5.1.3(c) contains the physical inspection ranking for the liquid SUNPAKTM components for June 27, 1978. Figure 5.1.3(d) contains the initial report for the Model SEC-601 collector components. The tube retainer component (panel item No. 3) of the Model SEC-601 co1lector uses the same material as the liquid SUNPAK ${ }^{T M}$ component panel item No. 6 except that the polycarbonate source was changed from G.E. to Mobay. All other components of the liquid SUNPAKTM collector module demonstrate long term resistance to the attack of airborne pollutants under conditions of adverse severity to an extent that no significant impairment to the intended performance of the components during their design life would be expected.

The components of the Model SEC-601 collector are considered to meet the criterion of Section 5.1 .3 by similarity. Further, a design 
review of the Model SEC-6C1 collector indicates ihat the only non17, $\because \therefore \therefore$ metallic parts subject to direct exposure to solar radiation are PHSK-5103 (MS-1022) and PN- SK-5067 (MS-T021).

Review of items $5.1,5.1 .1,5.1 .3$ successfully completed.

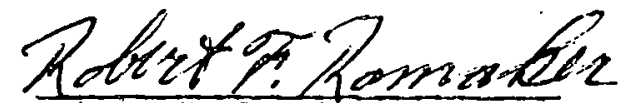

Robert F. Romaker

$0 . I$. Test Engineer

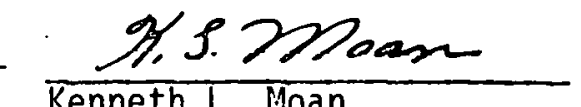

Moan

P.E. (Ohio 5203)

0.I. Approval

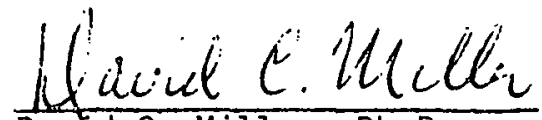
Davtd C. Miller, Ph.D.

SH\&G Certification Officer

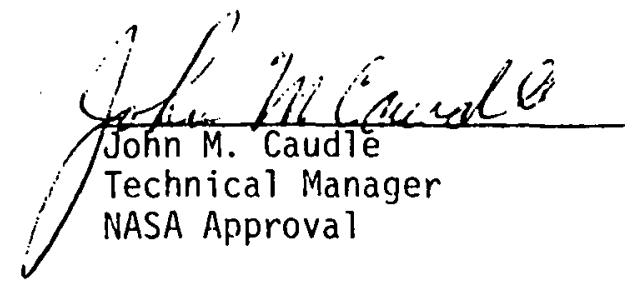

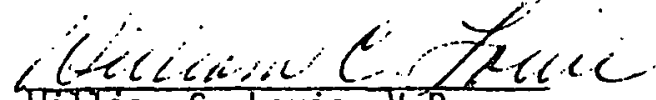
William C. Louie, V.P. P.E. (Mi. 11084)

SH\&G Certification officer 
OWENS-ILLINOIS

Stagnation Temperatures $-45^{\circ}$ South

\begin{tabular}{l} 
Solar \\
Time \\
\hline 1040 \\
1100 \\
1130 \\
1200 \\
1230 \\
1300 \\
1330 \\
1400 \\
1430 \\
1500 \\
1530 \\
1600 \\
1630 \\
1700 \\
1730 \\
1800 \\
1830 \\
1900 \\
1930 \\
2000 \\
2030 \\
2100 \\
2130 \\
2200 \\
2230 \\
2300 \\
2330 \\
0000
\end{tabular}

Tube Temperatures $\left({ }^{\circ} \mathrm{C}\right)$

\begin{tabular}{lll}
\hline & & \\
& $(0 F)$ & $\# 10$ \\
211.8 & 412 & 216.3 \\
251.8 & 485 & 261.2 \\
280.1 & 536 & 296.5 \\
289.7 & 553 & 305.3 \\
293.5 & 560 & 305.0 \\
296.7 & 566 & 303.6 \\
297.8 & 568 & 299.0 \\
297.8 & 568 & 295.2 \\
296.7 & 566 & 292.3 \\
293.7 & 561 & 288.1 \\
286.8 & 548 & 283.5 \\
277.8 & 552 & 276.1 \\
265.0 & 569 & 255.6 \\
249.9 & 482 & 219.3 \\
222.5 & 435 & 178.9 \\
175.2 & 347 & 143.6 \\
140.6 & 285 & 118.7 \\
114.0 & 267 & 99.3 \\
94.7 & 202 & 84.8 \\
81.2 & 178 & 74.2 \\
71.1 & 168 & 66.3 \\
63.6 & 145 & 60.2 \\
57.8 & 136 & 55.3 \\
52.9 & 127 & 51.0 \\
48.9 & 120 & 47.3 \\
45.6 & 114 & 44.4 \\
42.8 & 109 & 41.9 \\
40.4 & 105 & 39.8 \\
196 & &
\end{tabular}

August 11,1976

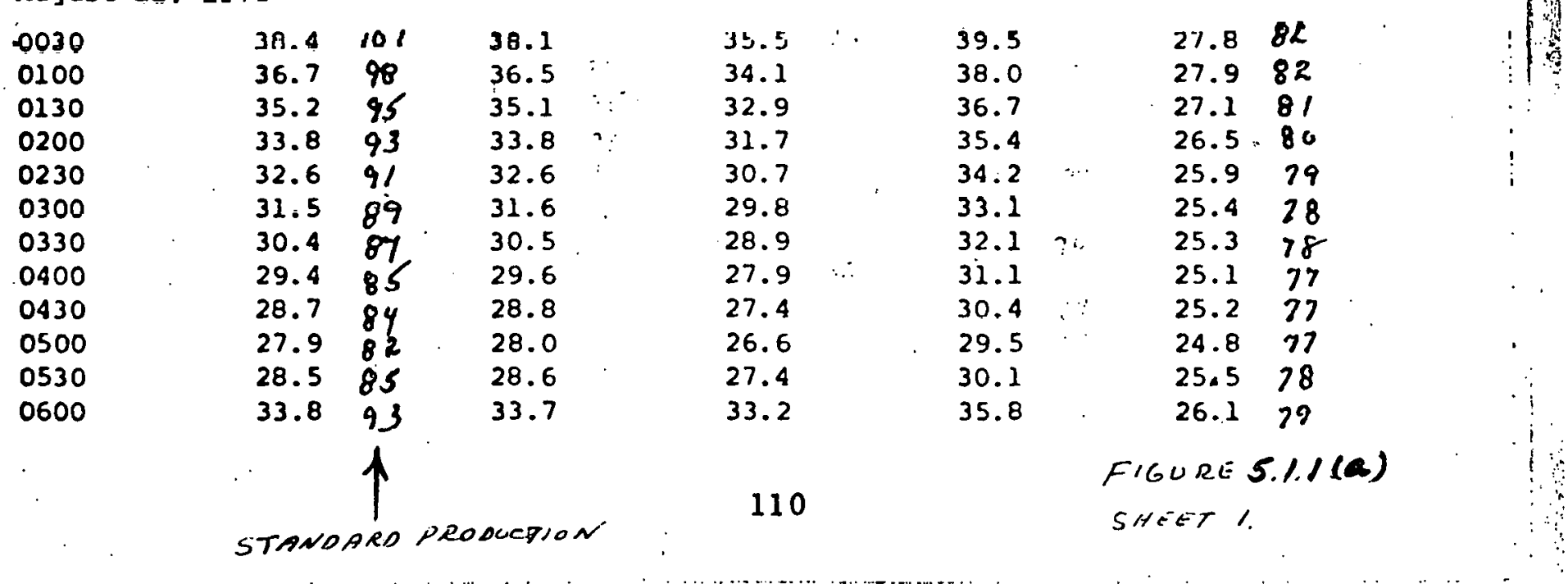

$\# 11 \quad \frac{\$ 12}{2} \frac{\begin{array}{c}\text { Ambient }(B T u / p t .2 / h r) \\ \text { Temperature }\end{array}}{(-\theta F)}$

220.9

213.0

258.3

257.1

283.1. . $\quad 295.7$

290.0 : $\quad 312.1$

291.6

292.0

288.8

286.0

282.1

276.5

272.2

$31 \% .5$

318.4

317.5

312.3

305.0

296.6

266.4

286.0

246.1

213.4

173.5

138.8

113.8

93.6

79.2

68.7

61.2

55.6

51.0

47.2

43.9

41.3

39.0

37.1

271.1

235.5

194.6

153.1

125.4

102.6

86.6

75.3

67.0

60.6

56.1

52.3

48.8

45.8

43.3

41.2

35.696

36.197

36.798

36.998

37.1

99 .

36.9

98

37.5

100

37.3

99

$37.7 \quad 100$

$39.4 \quad 103$

$39.1 \quad 102 \quad 166$

$38.5 \quad 10.131$

$37.7 \quad 100$

$37.3 \quad 99$

37.299

36.598

$35.4 \quad 96$

$34.5 \quad 94$

33.7

73

3.192

32.490

$31.8 \quad 89$

30.4

$29.4 \quad 85$

$28.5 \quad 83$

28.483

28.183

27.782

281

290

292

291

270

248

226

199

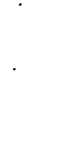


LUSERT SUNSHINE EXPOSURE TESTS, INC.

WATER TUBE STAGNATION

ONENS-ILLINOIS

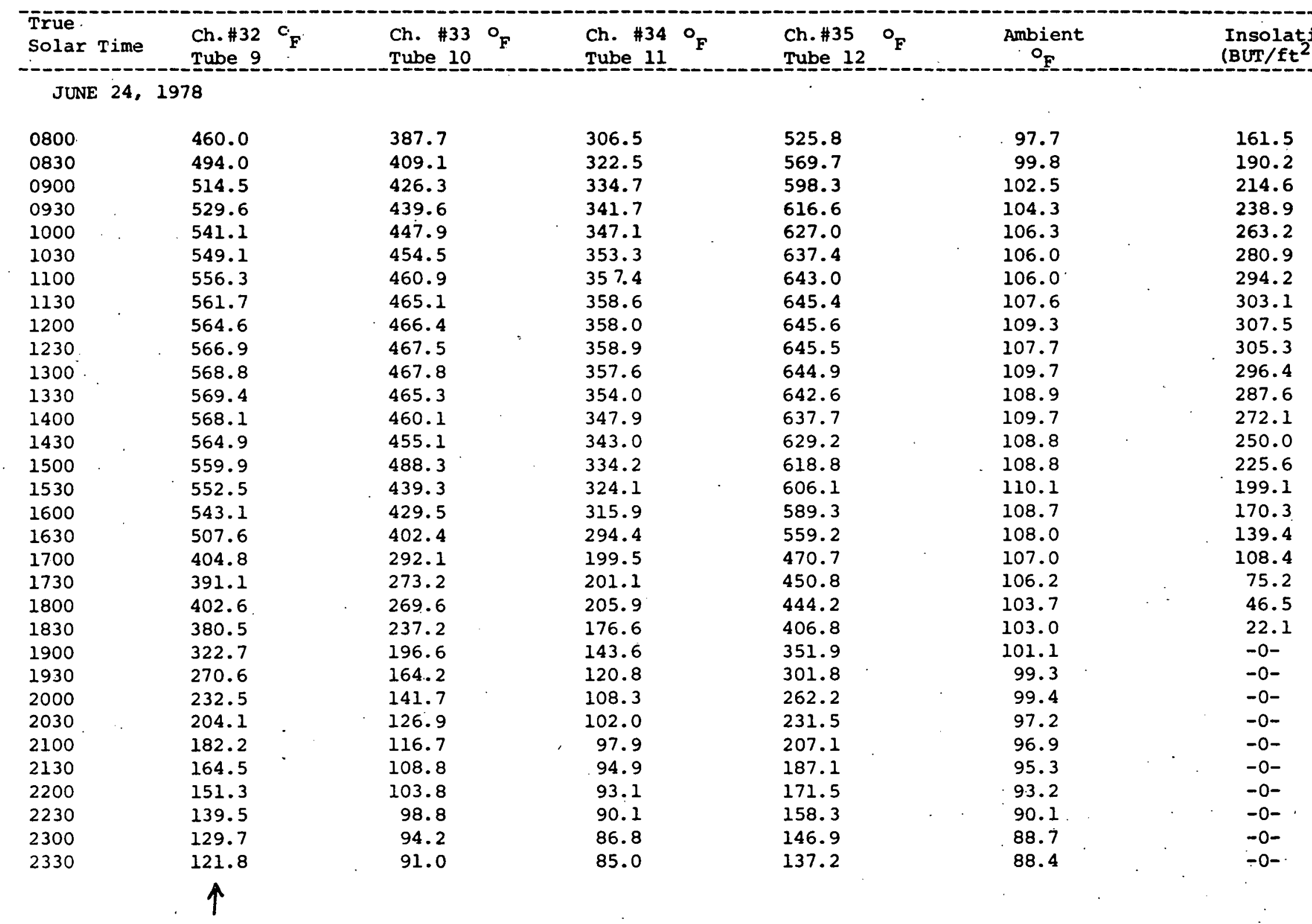

STANDARD PRODUCTION 
DESEI JunSHINE EXPOSURE TESTS, INC.

OWENS-ILIINOIS

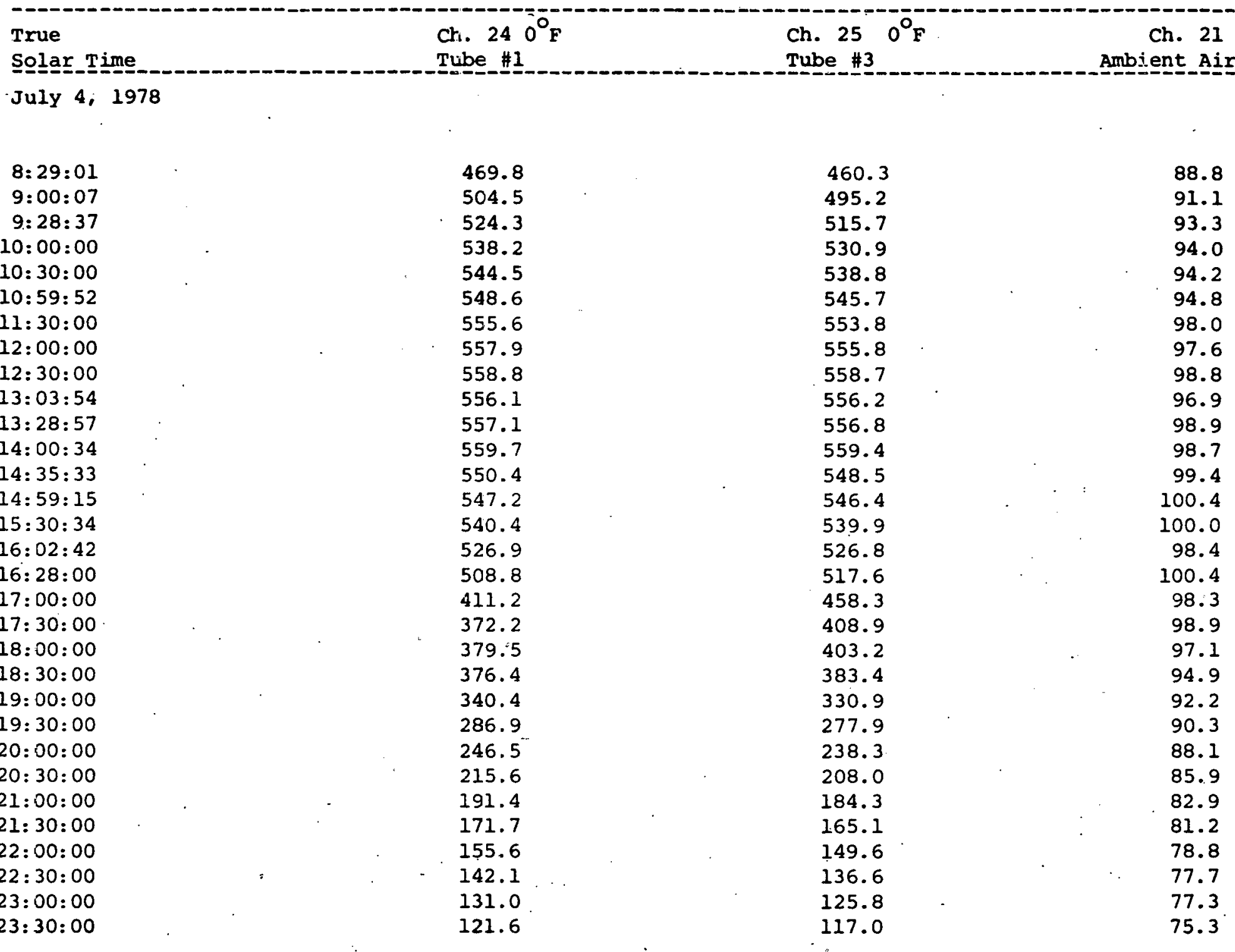







INSPECTION REPORT

P.O. M98-4442 dtd $7 / 19 / 76$ OUR ORDER 166055

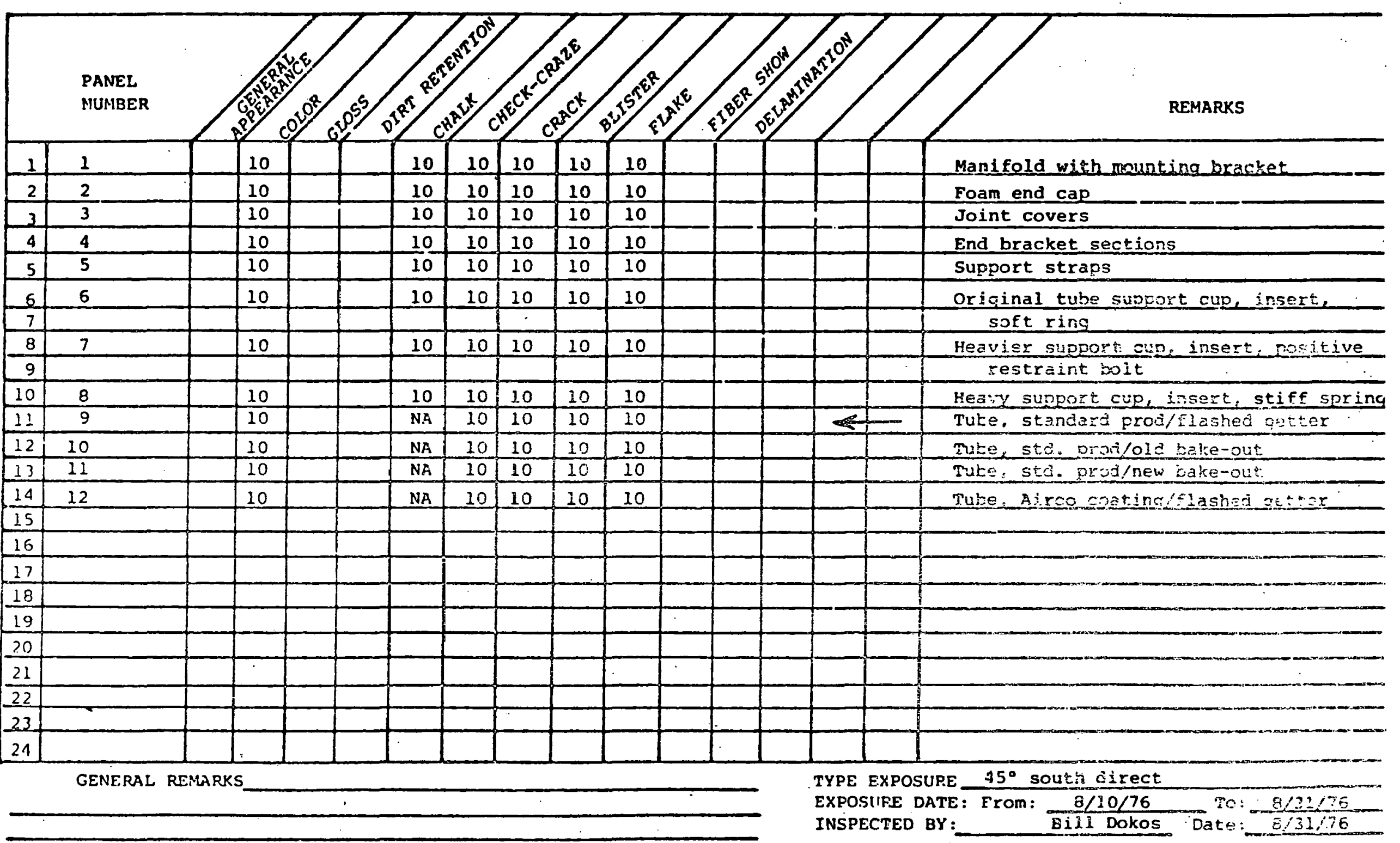

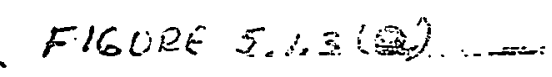


NUMBER AND DESCRIPTIVE RATINGS FOR WEATHERING TESTS

\begin{tabular}{|c|c|c|c|c|}
\hline \multicolumn{3}{|c|}{ FSPT } & \multicolumn{2}{|c|}{ Other } \\
\hline Number & Afgea rance & $\begin{array}{l}\text { Failure } \\
\text { (cleeck, chsik, etc.) }\end{array}$ & Appearance & $\begin{array}{c}\text { Failure } \\
\text { (check, chalk, etc.) }\end{array}$ \\
\hline $\begin{array}{r}10 \\
9 \\
8 \\
7 \\
6 \\
5 \\
4 \\
3 \\
2 \\
1 \\
0\end{array}$ & $\begin{array}{l}\text { as received } \\
\text { good } \\
\text { intermediate } \\
\text { poor } \\
\text { poorest degree } \\
\text { conceivable }\end{array}$ & $\begin{array}{l}\text { absent } \\
\text { slight failure } \\
\text { intermediate }\end{array}$ & $\begin{array}{l}\text { as received } \\
\text { excellent } \\
\text { good } \\
\text { good to fair } \\
\text { fair } \\
\text { fair to poor } \\
\text { poor } \\
\text { poor to very poor } \\
\text { very poor } \\
\text { extremely poor }\end{array}$ & $\begin{array}{l}\text { none } \\
\text { very slight } \\
\text { slight. } \\
\text { slight to considerabla } \\
\text { considerable (maxked) } \\
\text { considerabie to severe } \\
\text { (marked to yery minea) } \\
\text { severe (very narked) } \\
\text { sovere to very severe } \\
\text { almost complete } \\
\text { compiete } \\
\end{array}$ \\
\hline
\end{tabular}

Nurerical zeadings of gloss will be made with the Gardner "Multiangle" Glossmeter. Please specify:
(1) Angle
(?) Area of panel 20 be cleaned
(3) Manner in which panel is to be cleaned

DESERT SUNSHINE EXPOSURE TESTS, INC. - Phoenix, Arizona 
DESERT SUNSI EXPOSURE TESTS, INC.

BOX 185

BLACK CANYON STAGE

PHOENIX, ARIZONA 85020

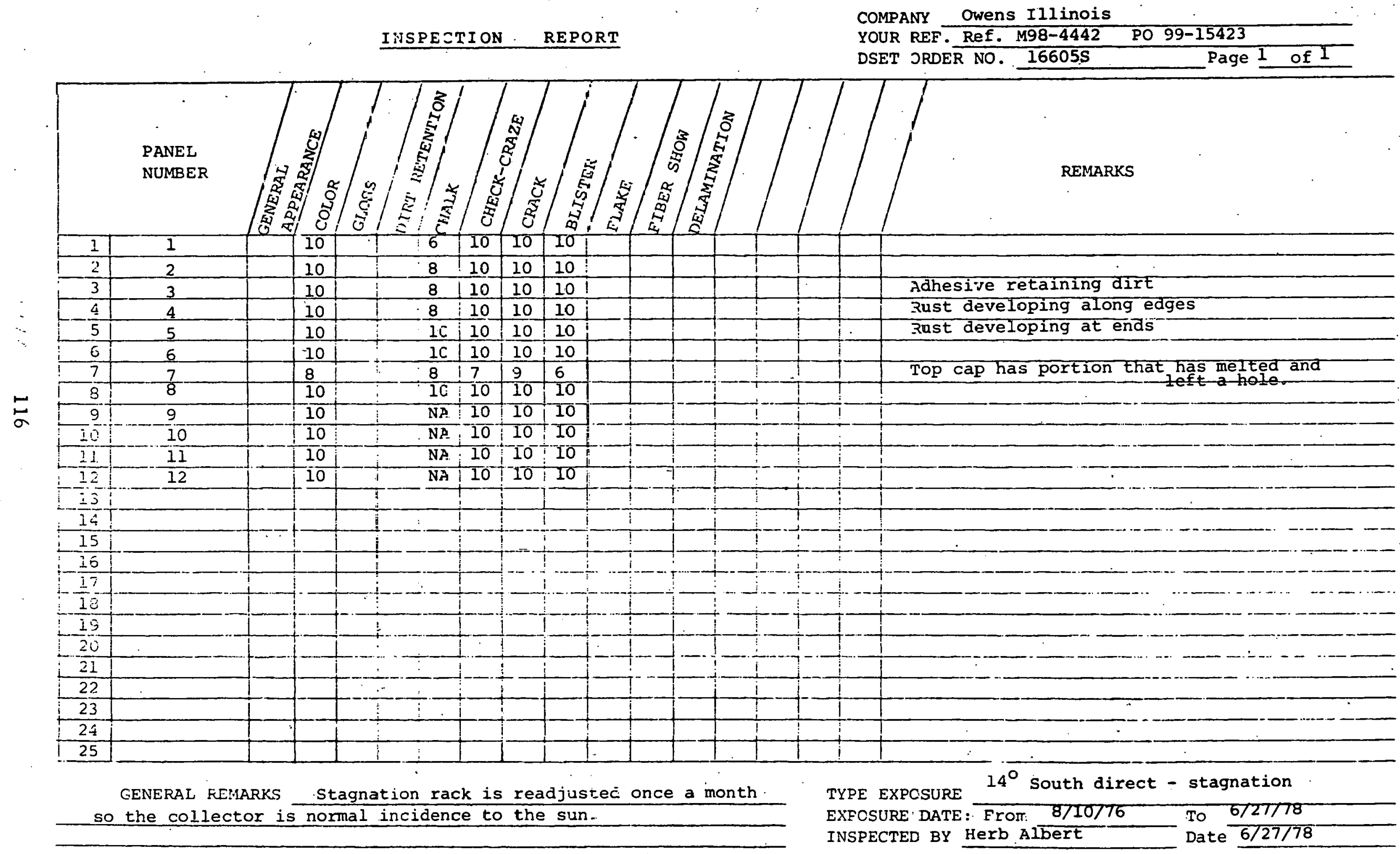

FIGURE 5.8.3(C) 
DESERT SUNSHIRE yPOSURE TESTS, INC.

BOX 185

BLACK CANYON STAGE

PHOENIX, ARIZONA 85020

INSPECTION REPORT

COMPANY Owens Illinois

YOUR REF. Ref. M99-2952 PO 98-1101

DSET ORDER NO. 19174SA

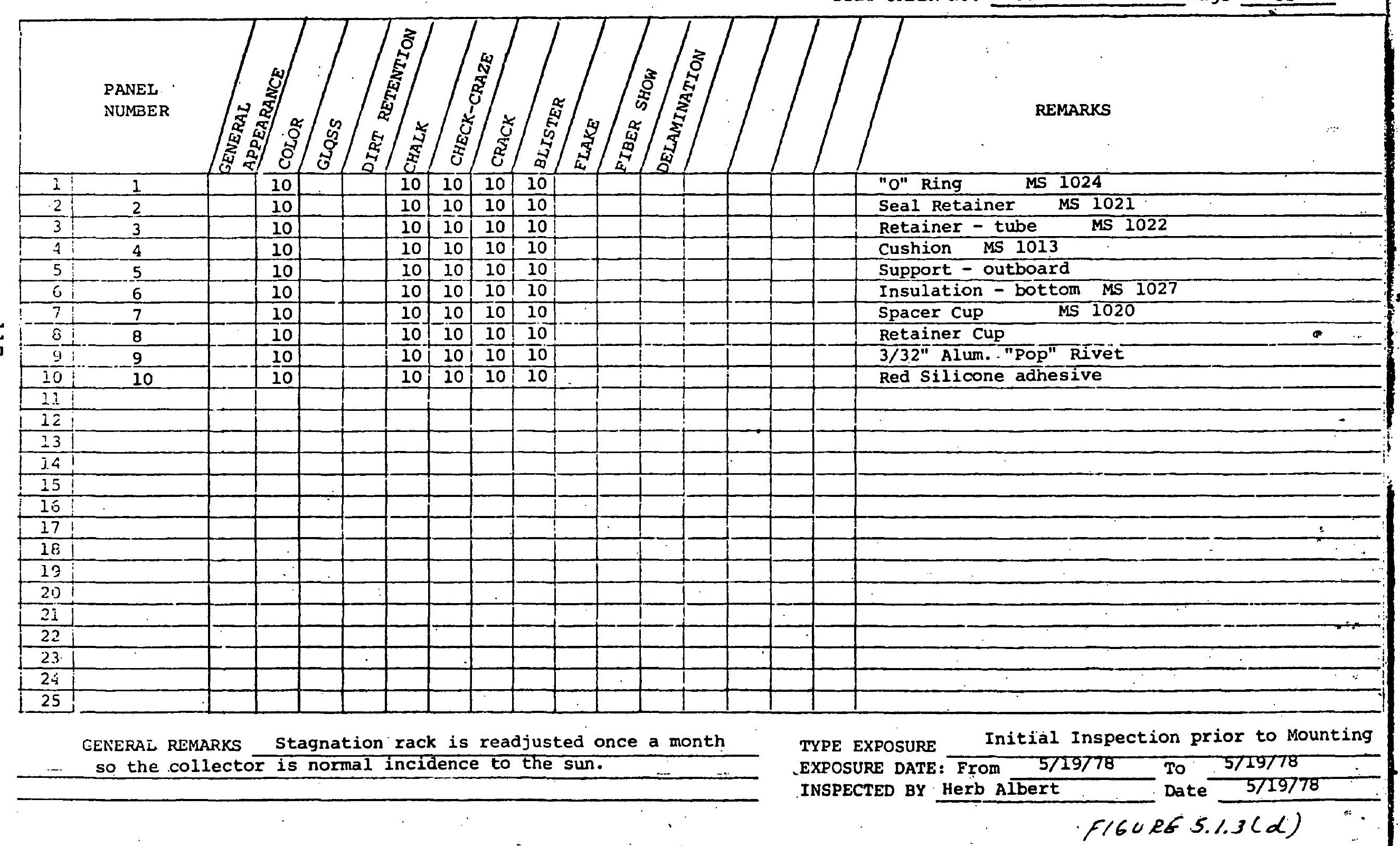


5.1.4 Dirt Retention on Cover Plate Surface.

All tubes used in the ERDA air collector were rated by sun testing on November 1, 1976. The procedure used was the placement of sets of twenty two (22) tubes in a rack tilted at $45^{\circ}$ from the horizontal. A white backing screen was provided consișting of outdoor marine plywood painted with flat white Dutch Boy paint. The rack was periodically relocated to face the sun. The test period was determined by the indicated temperatures reaching steady state. The tubes were retested on July 14, 1977 and again on March 28, 1978. A sample of the test data is in Figure 5.1.4(a). The tubes were washed only by the natural conditions of rain or melting snow over the seventeen (17) month test period. There is no significant deterioration in thermal performance due to dirt retention on the cover tube surface.

\subsubsection{Abrasive Wear.}

KG-33 borosilicate glass has the highest rating for the lasting quality of its surface of the commonly available glass compositions as indicated by the data of Figure 5.1.5(a).

\subsubsection{Fluttering By Wind.}

The only r.nmpnnent of the Model SEC,-601 cnllector subject to flutter induced vibration due to wind action is the collector tube element. Such vibrations are caused by vortices leaving the down stream side of the tube; this phenomena is known as Von Kármán vortex sheets. Figure 5.1.6(a) contains a discussion and a graph bearing on the subject. The information is taken from "Boundry Layer Theory," by Herman Schlichtrig, translated by Dr. J. Keston, Fourth Edition, McGraw Hill. 
Figure 5.1.6(b) is derived by using the graph of Figure 5.1.6(a) and calculating Reynolds' Numbers for wind velocities from 0 to $120 \mathrm{MPH}$, with $\mathrm{D}=53 \mathrm{~mm}(.1739 \mathrm{Ft}$.$) and y=.180 \times 10^{-3} \mathrm{Ft} .{ }^{2} / \mathrm{sec}$. The cross hatch area near the origin in Figure 5.1.6(b) shows the wind speed range in which regular vortex sheets are formed. Above this small wind speed region, the wake is turbulent and regular vortex sheets are not formed; that is, no real flutter frequency is established. Also shown in Figure 5.1.6(b) is the location of the two resonant frequencies of the absorber tube F... measured by a scan of 0 to $300 \mathrm{~Hz}$. on a vibration shake table. These are both far removed from the frequency range where the vortex sheets occur. The conclusion from this data is that wind induced flutter frequencies will not excite the resonant frequencies of the collector tube elements.

Review of items $5.1 .4,5.1 .5$ and 5.1 .6 successfully completed.

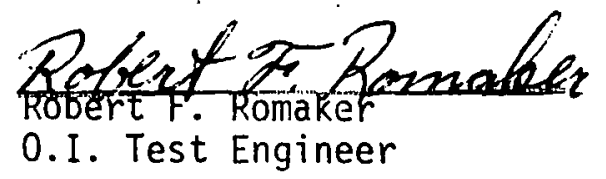

Kenneth L. Moan

P.E. (Ohio 5203)

$0 . I$. Approval

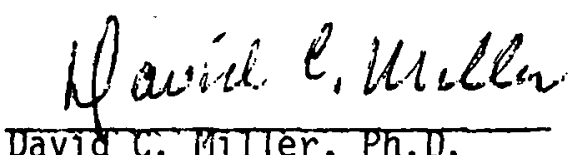
David C. MitTer, Ph.D.
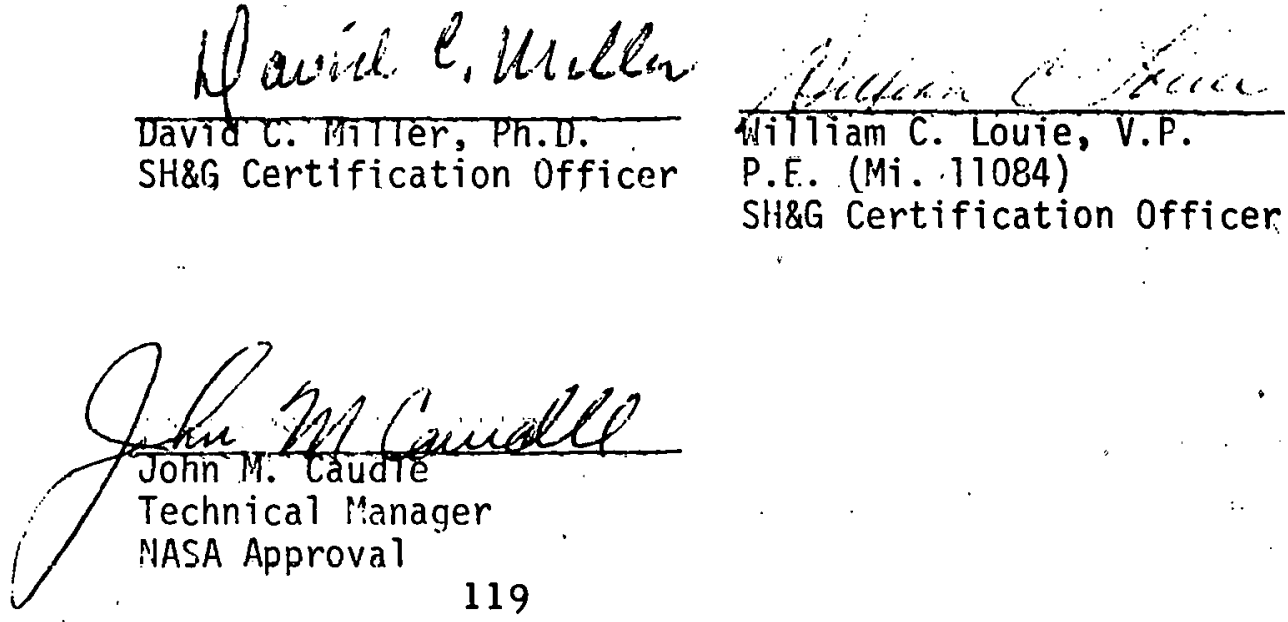


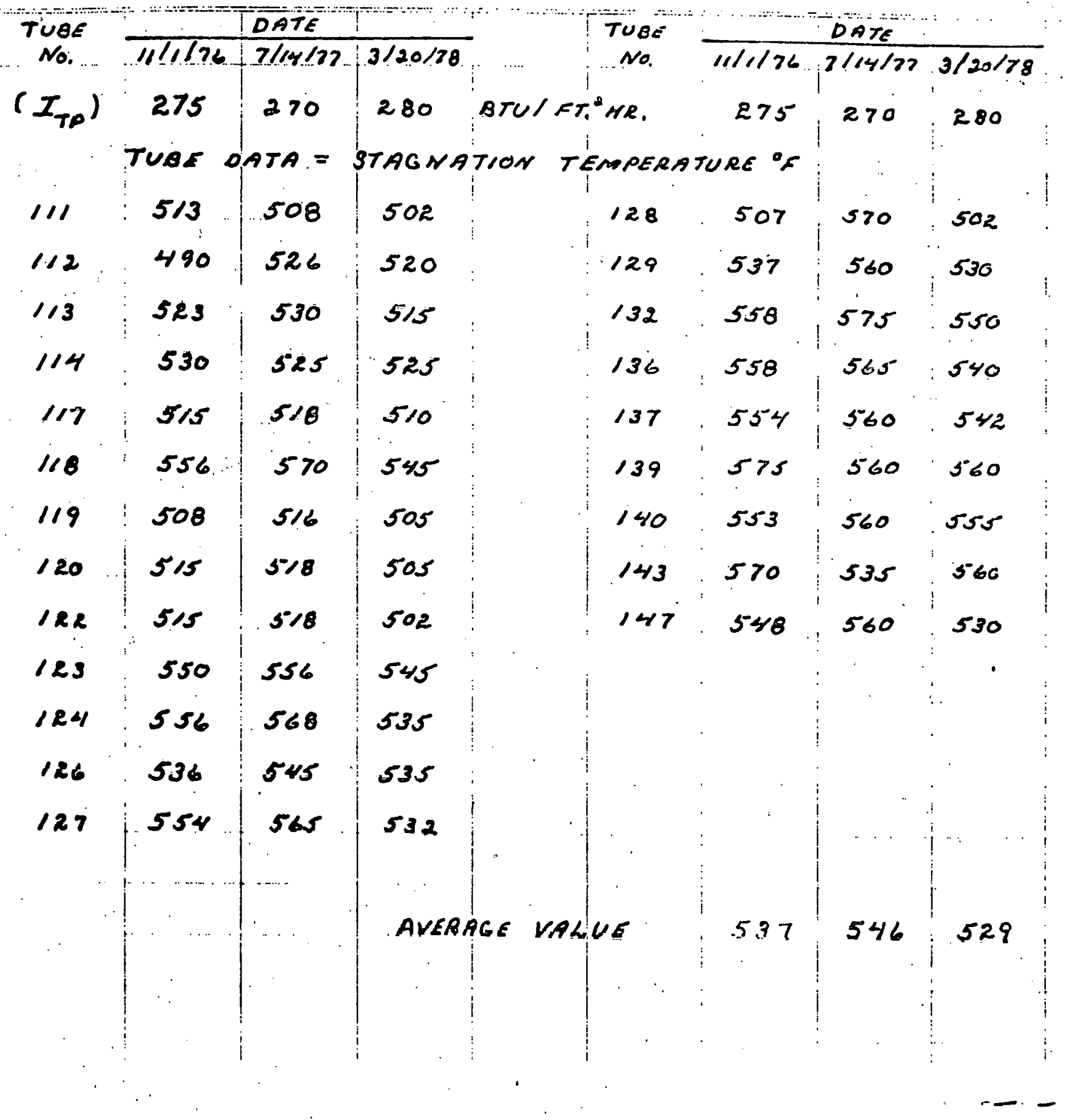


Chemical Durability is the lasting quality of a glass surface. It is frequently evaluated, after prolonged weathering or storing, in terms of chemical and physical changes in the glass surface or in terms of changes in the.contents of a glass vessel. The glass which is best suited chemically in one situation is often inferior in another. This information book covers glassware intended for many different uses. For many of these, special tests or prolonged observation in service are required to establish excellence. Great differences exist in the chemical properties of glasses customarily used for these different purposes. The result obtained in an arbitrary test should therefore be interpreter with caution.

In this information book, typical values are given for several crushed-sample tests in order to indicate chemical durability broadly. A glass is handled in a specified manner to yield $10 \mathrm{~g}$. of crushed grains that pass a No. 40 sieve and are retained by a No. 50. In ASTM Test P.W (ASTM Designation C225), this glass is exposed to the action of specially purified water at $121^{\circ} \mathrm{C}$. for 30 minutes after which the alkaline material extracted is determined by titration. The result is expressed as "ml. $0.02 \mathrm{~N} \cdot \mathrm{H}_{2} \mathrm{SO}_{4} "(\mathrm{ml}$. N/50 $\mathrm{H}_{2} \mathrm{SO}_{4}$ ) used in the titration. This procedure is des. ignated as the Powdered Glass Test by the United States Pharmacopeia (USP. XVII, pp. 900-901) where it is the basis of the following container specifications.

\begin{tabular}{|c|c|c|}
\hline Type & General Description & Limits \\
\hline I & $\begin{array}{l}\text { Highly resistant, } \\
\text { borosilicale glass }\end{array}$ & 1.0 \\
\hline III & Soda-lime glass & 8.5 \\
\hline NP & $\begin{array}{l}\text { General-purpose } \\
\text { soda-lime glass }\end{array}$ & 15.0 \\
\hline
\end{tabular}


The frequency with which vortices are shed in a Karman rortex stcect behind a circular cyllinder was first extensively measured by $\mathrm{H}$. Blenk, D. Fuchs and $L$. Liebers [2]. A regular Kaimun strect is observed only in the rimge of Reynolds numbers $V D^{\prime} V^{\prime}$ from about 60 to 5000. At lower Rernolds numbers the wake is Inminat and has the form visible in the first two photographs of Fig. 1.6; at higher Reynolds number's there is complete turbulent mixing. Yeilsurementa show that in the regular mange given alsove, the dimensionless fiequency,

$$
\frac{n D}{T^{-}}=S, \quad \text { (Strouhal number) }
$$

nlso known as the Strouhal nunber [20], depends miquely on the Reynolds number. This relationship is shown plottod in Fig. 2.9 which is bised on the more receit measurements performed by A. Roshko [10]. The experimental points which were olstained with cylinders of different diameters $D$ and at different velocities $V$ ariange themselves well on a single curve. At the higher Reynolds numbers the Strouhal number remains approximately constint at $S=0.21$. When the diameters of the cylinders are small and the velocitics are modcrate, the resulting frequencies lie in the acoustic range. For example; the familiar "icolian tones" emitted by tclegraph wires are the result of these phenomena. At a relocitr of $r=10 \mathrm{~m} / \mathrm{sec}$ . $(30.48 \mathrm{ft} ; \mathrm{sec})$ and a wire of $2 \mathrm{~mm}(0.079 \mathrm{in})$ in diametcr, the frequency becomes $u=0.21(10 / 0.002)=1050 \mathrm{sec}^{-1}$, and the corresponding Reynolds number $R \approx 1.200$.

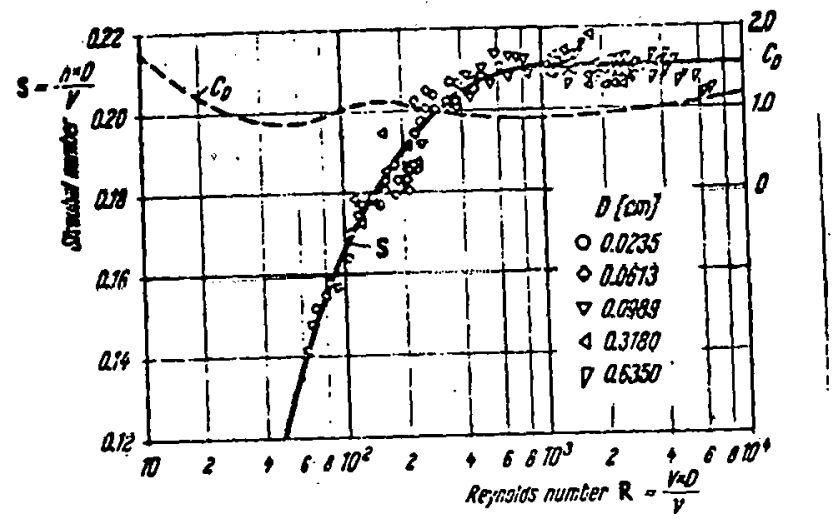




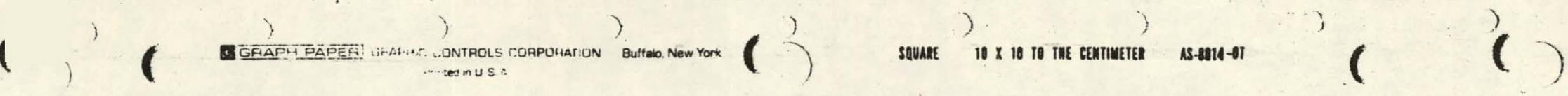

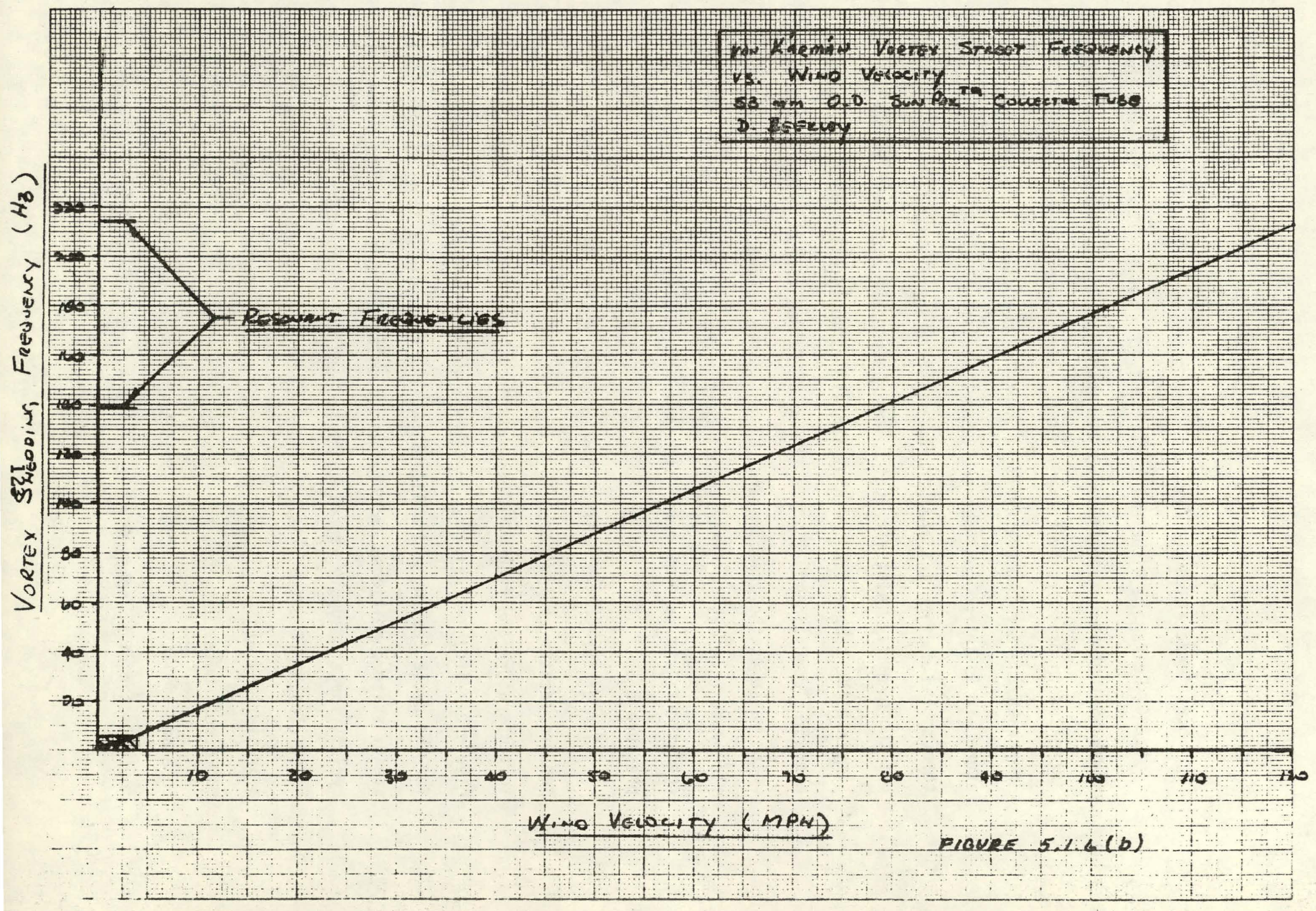




\subsection{Temperature and Pressure Resistance.}

5.2.4 Leakage. A thermal cycle test loop was built containing the elements indicated schematically in Figure 5.2.4(a). Ambient air is increased in pressure by the air fan. An electric heating element increases the air temperature to a preselected level. The high temperature air is introduced into the normally exit air duct. The air flows through the ducting internal to the manifold and the tube elements and out the normally inlet air duct. The reverse air flow path is used to simulate the temperature gain of the air as would exist under normal operating conditions. The air flow rate is monitored by the inclinometer which measures the pressure drop of the collector due to air flow. The flow rate used was in the range of that expected under normal operating conditions; viz. a flow rate which causes approximately 0.3 inches w.g. pressure drop.

Temperatures were monitored on a strip chart recorder with the sensors located as indicated in Figure 5.2.4(b). The three hour cycle to temperature and return to essentially ambient conditions as shown in Fiqure 5.2.4(c) was selected to allow a reasonable total elapsed time for the cycle testing and still allow all temperatures to reach essentially steady state conditions. After the accumulation of a selected number of cycles, the air supply was disconnected and the inlet and exit ducts taped closed. One tube was removed allowing the direct connection of a pressurized air supply to the air manifold. A rubber stopper, with two access holes was inserted into the manifold well in place of the tube and silicone seal. The second access hole was connected to an inclinameter of 5 inches w.g. total range for an accurate measurenent 
of pressure. A precision air flow meter was used to measure the volume of leakage air flow.

The regulated air supply provided a precise control of manifold pressure from 0 to 5 inches w.g. The manifold pressure was set and allowed to stabilize. The volume of air flow required to maintain the selected manifold pressure is a measure of the leakage flow rate of the collector. Since time was required to make the change over, leakage air flow at the maximum temperature condition could not be accomplished. Therefore; a qualitative indication of leakage flow at, maximum temperature was obtained by simply taping shut the exit flow duct. A smoke bomb was fired and the smoke ingested into the inlet to the fan. At no time could any evidence of leakage as indicated by a smoke pattern be detected.

The measured leakage flow rate after the accumulation of various numbers of thermal cycles is indicated in Figure 5.2.4(d). It will be: noted that the high temperature condition was approached in steps as a precautionary measure. The principal features of the data are first the very low leakage flow rate measured at the order of $0.1 \%$ of operating flow and second the lack of any trend towards an increase in leakage flow rate. The scatter in the data indicates that the tightness with which the flow ducts were enclosed and with which the pressure source and inclinometer were attached to the manifold caused variations in the measured value of leakage flow rate as large as the leakage volume flow itself. Note that leakage flow was measured up to 5 inches w.g. which is a factor of 10 or more nigher than the collector pressure drop itself: 
Upon physical examination there was no sign of creep or embrittlement of the silicone seals.

\subsubsection{Deterioration of Gaskets and Sealants.}

The tests conducted and described in Section 5.2.4 are evidence of the capability of the gaskets and sealants to withstand operating service conditions. It is felt that the very low leakang evidenced at high temperature (smoke bomb tests) and near ambient conditions (direct leakage flow measurement) represent more demanding requirements than those of the approved Acceptance Test Procedure. The carability of the materials to operate satisfactorily after exposure to extreme cold conditions was evidenced during the extreme weather conditions of the Toledo winters of 1977 and 1978. Examination of the gaskets and sealants used in the ERDA. collector array upon disassembly of a manifold after removal in March 1978 show ro signs of creep, embrittlement, cracking or other deterioration. Testing of the assembled array just prior to removal from the ronf showed no signs of loss of atility to perform the intended functions.

\subsubsection{Pransmission Losses Due to Outgasing.}

This section is not applicable to the Moder SEC-601 collector tube elements since the transmission path is a hard vacuum totally enclosed in herrietically sealed glass. However, this section. is applicable in intent since $a$ loss of yacuum due to oulgasing of the glass and/or selective surface or a deterioration of the selective surface due to long term exposure to the higin temperatures which can obtain under no flow conditions can cause a deterioration in performance. 
To accumulate evidence that the collector tube elements have the requisite long term stability under exposure to normal operating conditions, all of the tube elements of the ERDA air collector were ranked by a standard outdoor sunshine test. The tube elements were tested first on $10 / 30$ to $11 / 1,1976$. They were retested on $7 / 13 / 77$ and a sample lot retested $3 / 20 / 78$. The cover tubes were not cleaned at any time during the entire test period except by the natural processes of rain. and melting snow. The level of insolation, in the tilt plane of the outdoor test rack was noted for each day of test at the time the stagnation temperatures were measured. A suitable day for the stagnation tests was determined qualitatively as relatively "cloud clear" by the test operator.

The test data is shown in Figure 5.2.6(a). The change in the average value of stagnation temperature was of the order of $1.5 \%$, well within the possible experimental error. The tubes were subjected to no flow stagnation conditions almost every weekend and over the holiday periods from $11 / 15 / 76$ to $3 / 17 / 88$, a period of 17 months.

Three major installations, GSA Building, Saginaw, Michigan; Terraset School, Reston, Virginia, and the Troy Library, Troy, Ohio represent a total of 12,672 tube elements installed and operating under field service conditions. Tube elements have been replaced for apparent loss of thermal performance under the $0-I$ warranty agreement. The reason for failure has been investigated and in all cases was attributed to loss of vacuum due to a micro crack developing in one of the glass seal areas. No failure was attributed to outgassing or coating deterioration under field operating conditions. 
Review of itens $5.2 .4,5.2 .5$ and 5.2.6 successfully conpleted.

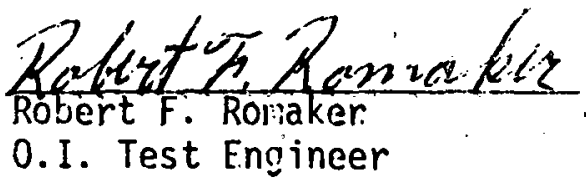

Kenneth L. Hoan

P.E. (Ohio 5203)

0.1 . Approval

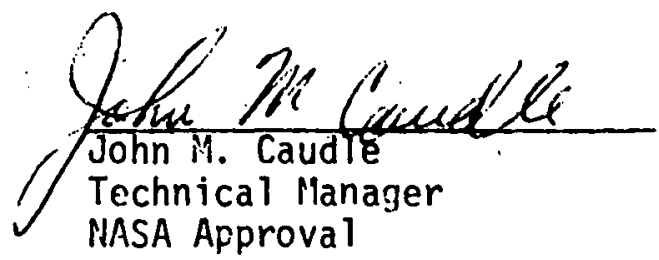

128 
THERMAL CYCLE ANO LEARAGE TEST SCHEMATIC

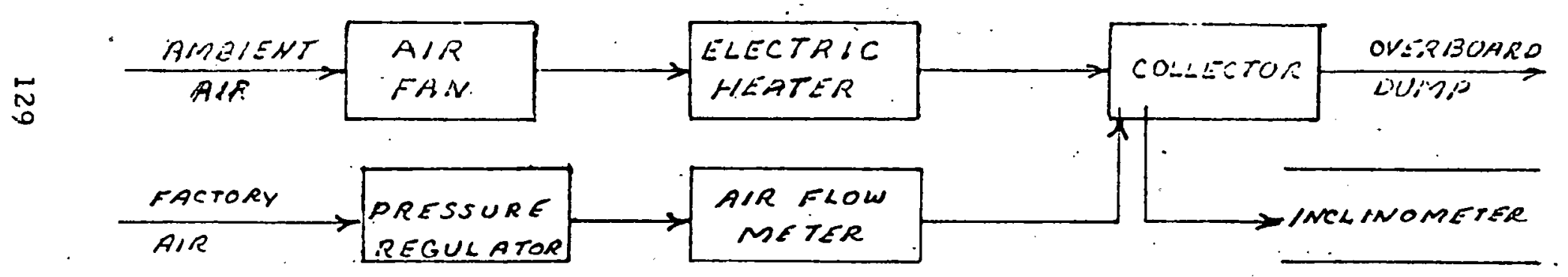

FICURE 5.2.4(a) 
COLLECTOR AIR AWL SURFACE TEMPERATURE SENSOR LOCATIONS

$\int_{\text {AMBIENT }}^{R}$

it

$\stackrel{\omega}{o}$

A pogrom surface cental

$\Delta / 2$

TOP SURFACE

\#TIDE SURFACE CENTER

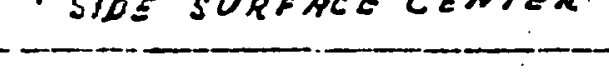

$\chi_{T \rightarrow B}$

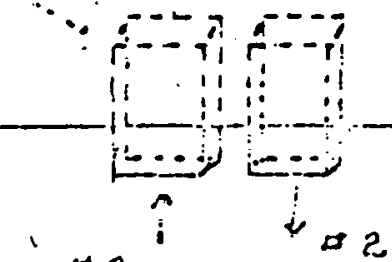

$\forall 5$

$t 3$

Thin our
$T_{W E L C}^{* ?}$

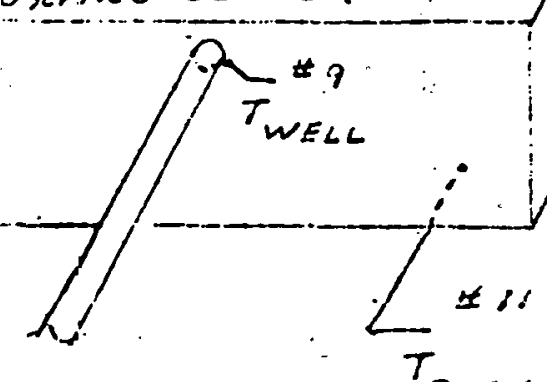

boTTOM SURFACE

FIGURE 5.2.4(b) 


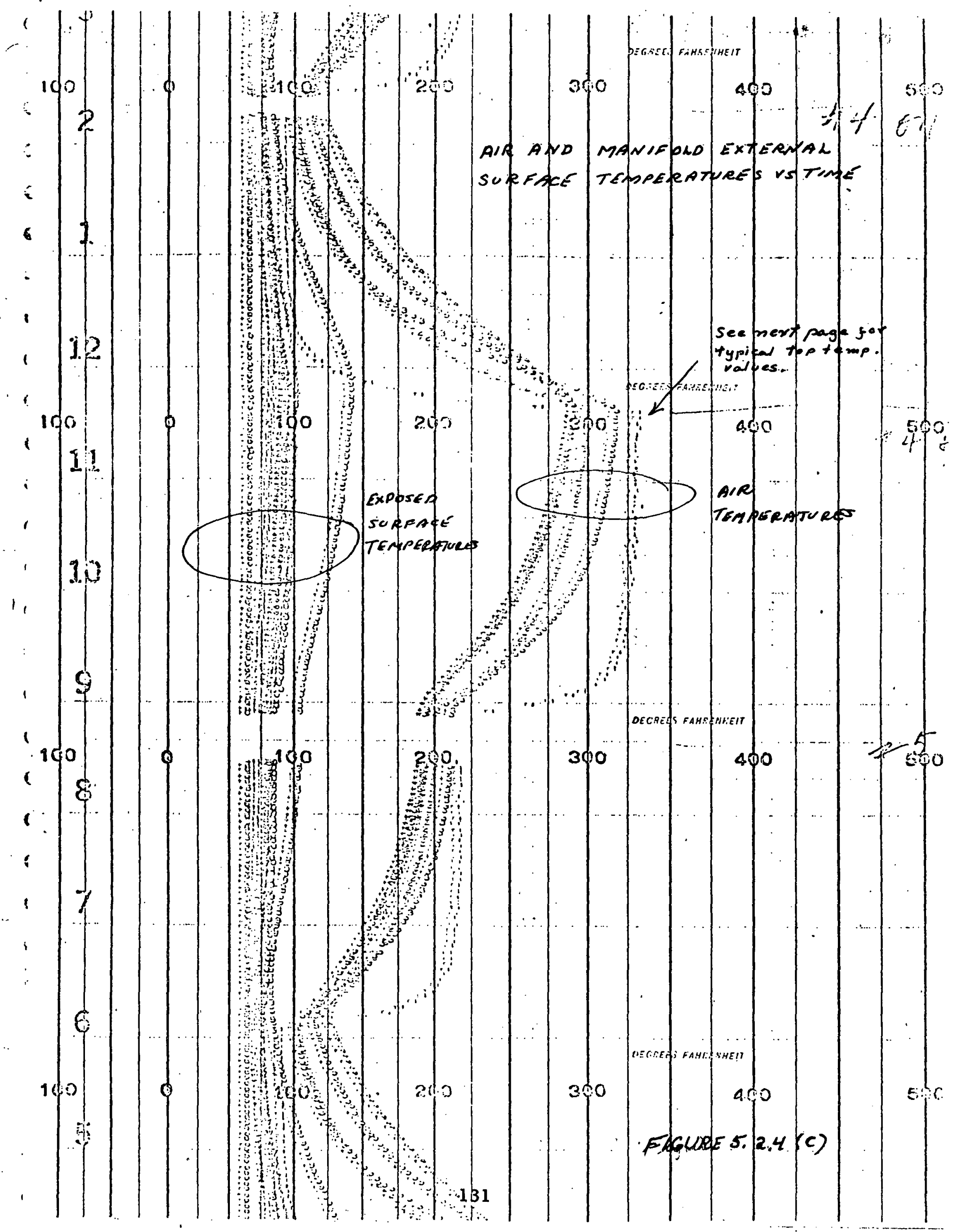


Project $S 221,12 B$

Date $224 R C H Z$

1975

128

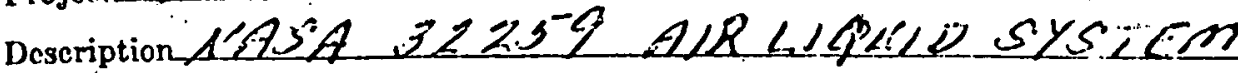

Y CYCLE TO $300 \%$

MAAYFOLD 4 TLBEL TLSMP.

TC TEMP HOSATION

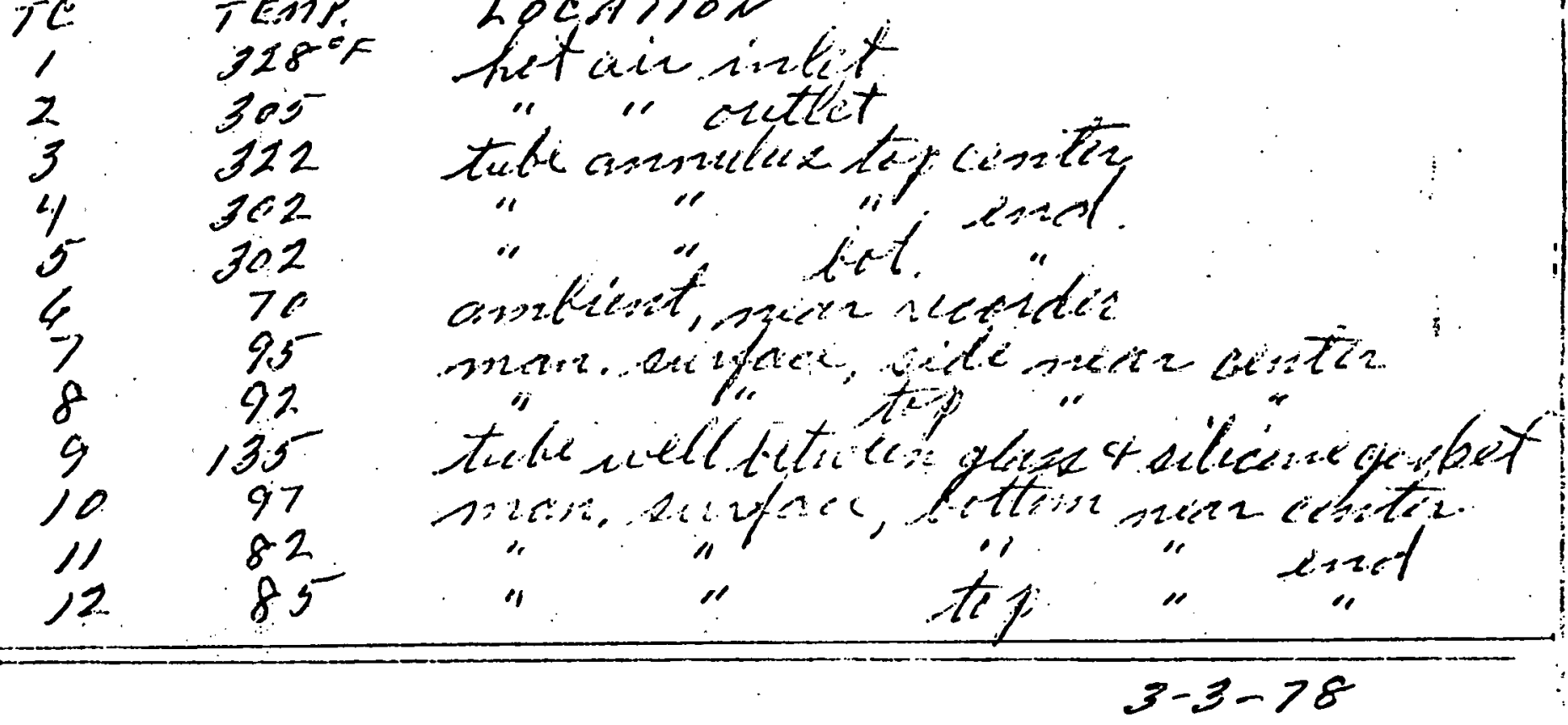

- LEAKAGE TEST

I CYCLE TO $300^{\circ}$

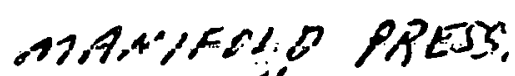

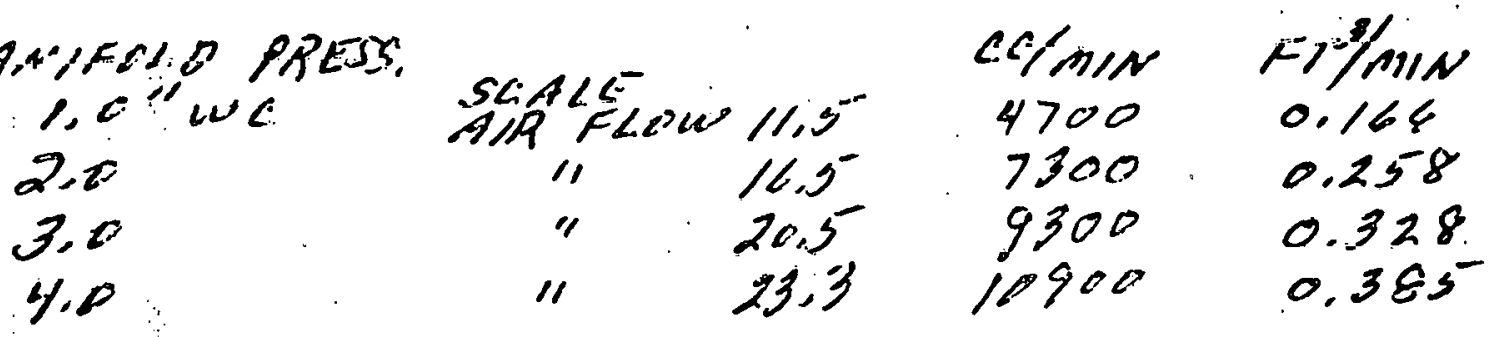

2 LYCLLS TO B00\%

$\$-2-7 \theta$

2 CYLLLS TO $300^{\circ} \mathrm{F}$

$3-7-78$

LCAKAGE TEST HSIAE SINOKL CANDLES

AHABLE TO DLTLCT ANY SMOKL LEAHAGL

BY VISEAL OBSERVATIEN

Pages to have been

sined-Robert Remafer

Witnessed by

132

Date 


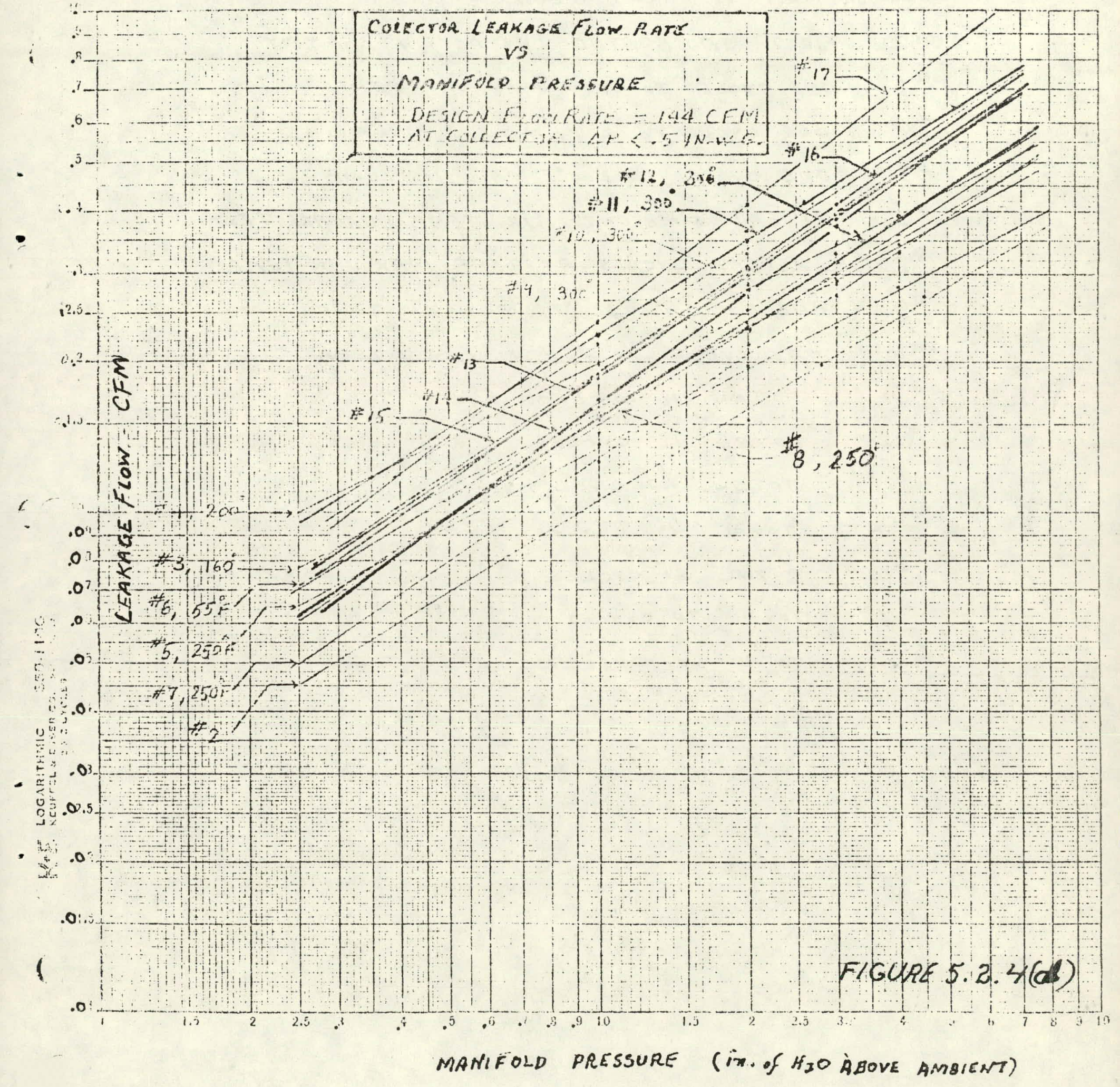




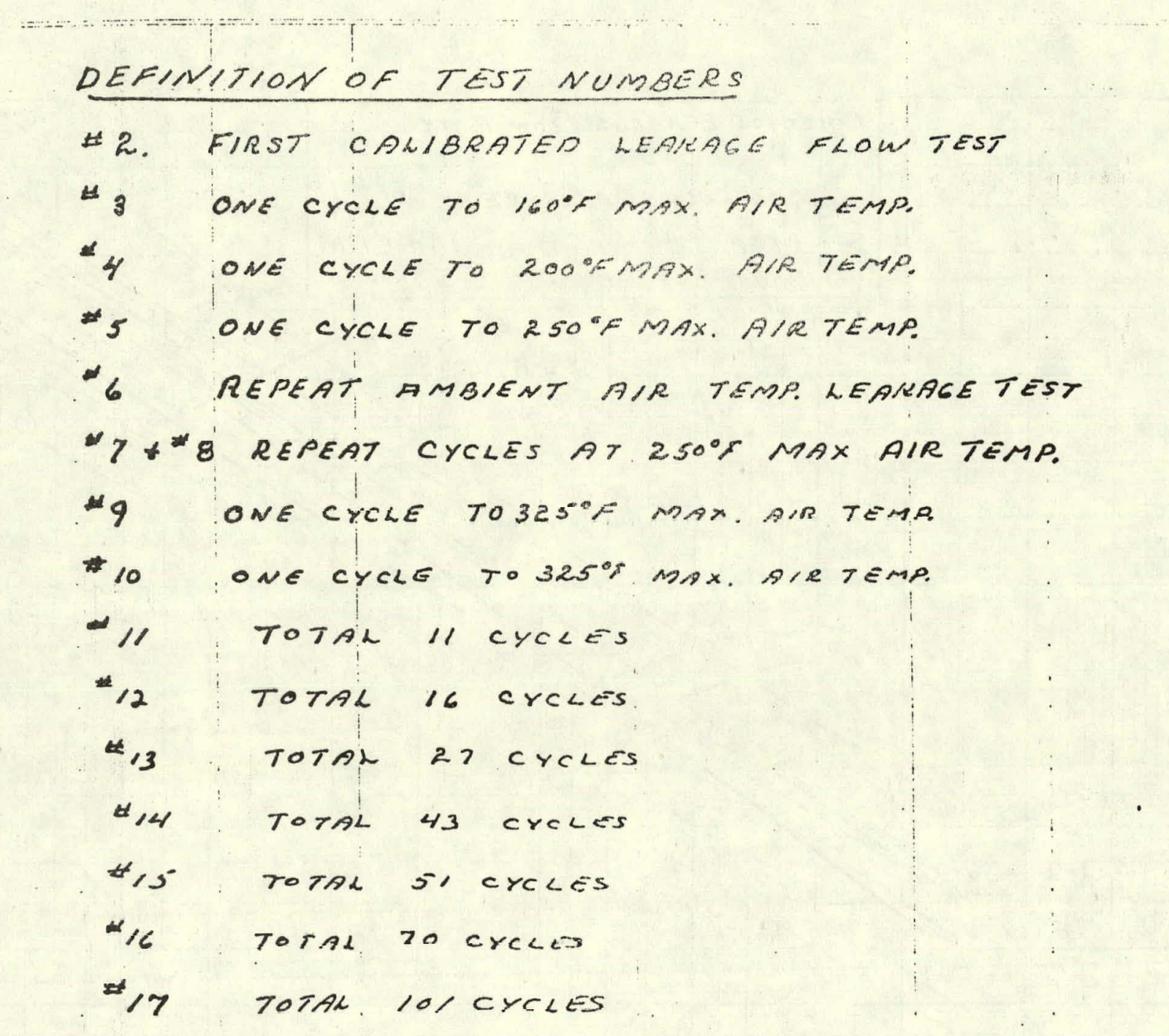




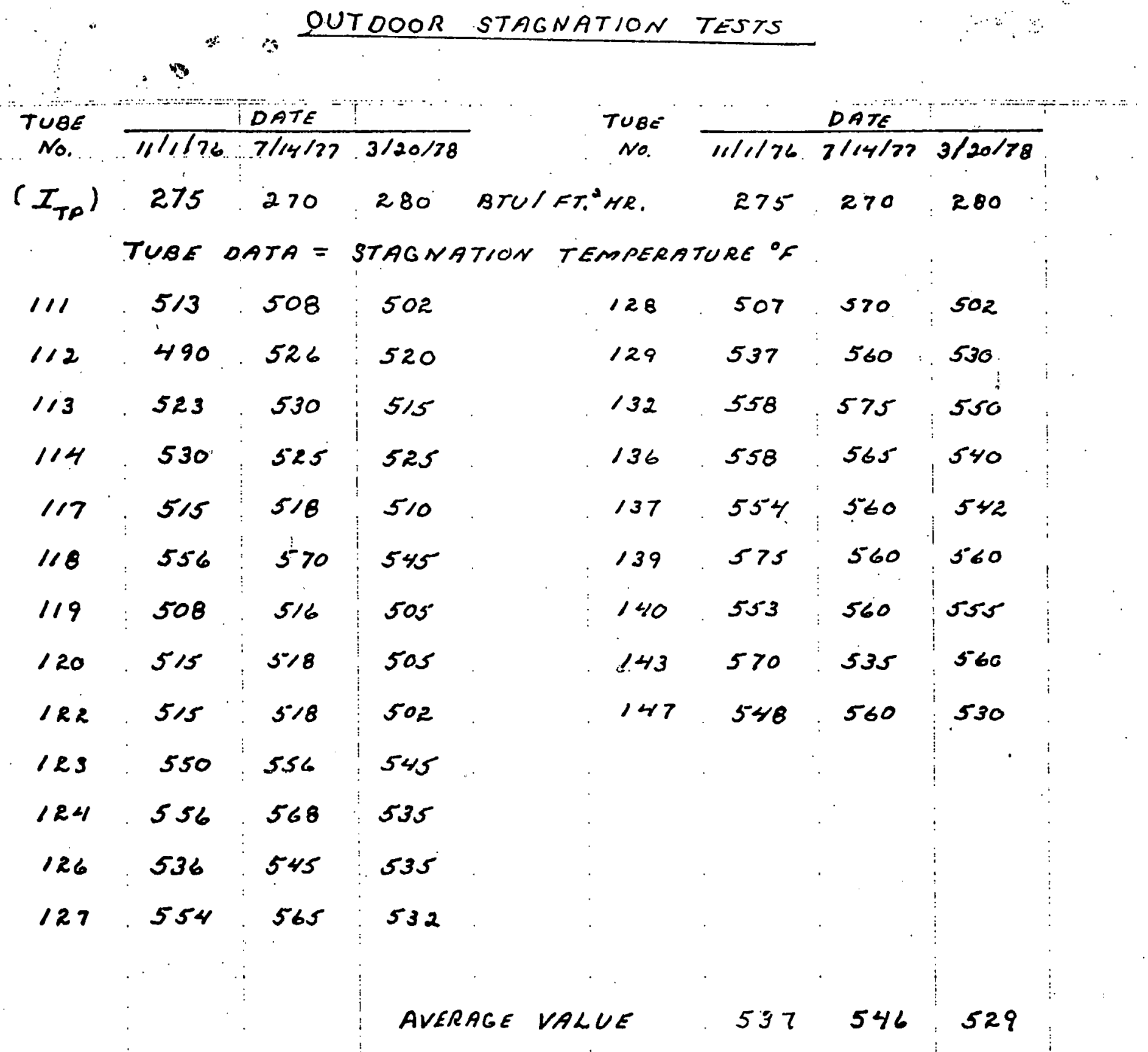


Decenber 12, 1977

\section{Intra-Company}

to

G. R. Mather - Dev. Ctr.

subject

VACUUH LOSS IN SUNPAK(TM) TUBES AT GSA BUILDING, SAGINAW, MICHIGAN, $11 / 30 / 77$

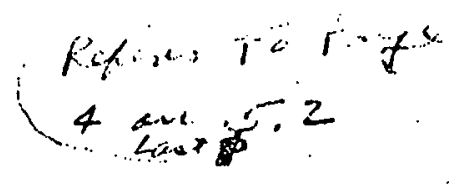

Seven tubes returned from the subject installation by Mr. E. G. J. LaBonte were examined to determine the cause of suspected vacuum degradation. The tubes had been selected out becausc thcy were warm to the touch.

A summary of the analys is is given in Table 1. Five of the seven tubes had a capillary channel in the tip-off. One tube had a pinhole in the tipoff tubulation seal to the cover tube. One tube had a crack in the cover tube due to external damage.

The above described tubes represent seven out of 1200 tubes in the first row or $0.58 \%$.

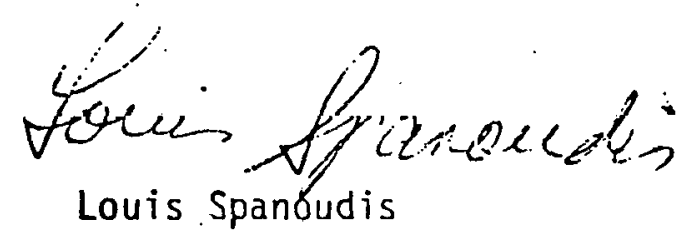

\section{LS/gS}


Table 1.

Analys is of Sunpak (TPI) Tubes With Susfected Poor Vacuum; Saginaw GSA Building; 11/30/77

Batch Number

A-197

A-206

A-282

A-134

$A-132$

A-206

A-730

\section{Anatys is}

Tip Off Capillary

Tip Off Capillary

Tip Off Capillary

Tip Off Capillary

Tip Off Capillary

Pinhole in Tubulation-Cover Tube Seal

Crack Due to External Cover

Tube Damage. 


\subsection{Chemical Compatibility of Components.}

The design and material specifications for the ERDA and the Model SEC-601 collectors were reviewed and it was judged that similarity could be used for compliance to the criteria of section 5.3. Since seyenteen months of service experience has been accumulated, only data from the ERDA array will be used. One of the two ERDA manifolds was disassembled to allow complete inspection of all critical components by a representative of the certifying agency.

\subsubsection{Materials/Transfer. Fluid Compatibility.}

No evidence of corrosion of the aluminum divider strip, the aluminum distributor tube or glass surfaces could be detected. In the Model SEC-601 collector, air flow is contained entirely within glass or al uminum materials.

\subsubsection{Corrosion of Dissimilar Materials.}

A review of the drawings and material specifications of the ERDA and Model SEC 601 collectors demonstrates that no non-dialectric materials are in contact. one with the other within active collector flow path. The only dissimilar metals in contact with each other are 6061 Type aluminum with Type 340 stainless steel in the support structure. These are compatible materials for the application.

\subsubsection{Corrosion by Leachable Substances.}

Upon close inspection of the ERDA manifold, no evidence of corrosion by leachable substances occurred. 


\subsubsection{Effects of Decomposition Products.}

A close inspection of the ERDA manifold and a review of performance data oyer the seyenteen (17) month test period demonstrates no impaiment in the ability of any of the components to perform their intended function. .

Review of items $5.3,5.3 .1,5.3 .2,5.3 .3$ and 5.3 .4 successfully completed.

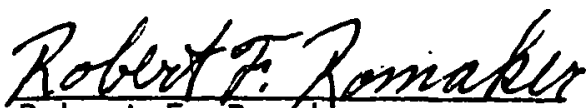

Robert F. Romaker

0.I. Test Engineer

Havid C. Miller David C. Miller, Ph.D. SH\&G Certification Officer

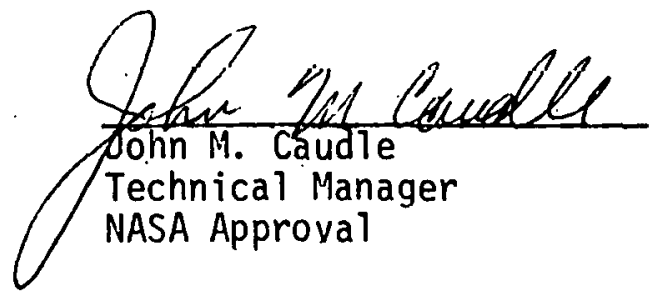

Kenneth L. Moan

P.E. (Ohio 5203)

0.I. Approval

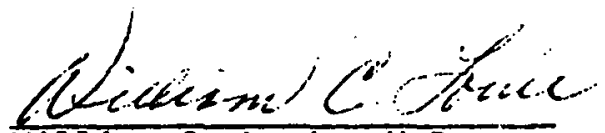
William C. Louie, V.P. P.E. (Mi. 11084)

SH\&G Certification Officer 


\subsection{Accessibility for Maintenance and Servicina.}

\section{$\therefore$ 6.1.1 Access for system maintenance.}

The Model SEC-601 collector subsystem has been designed for zero maintenance during its service life. However, the collector tube element could encounter service use failure due to natural causes such as unusual hail conditions or due to human factors such as vandalism or impact failure in handling. The need for replacement will be realized through visual observation of obvious glass breakage or by the detection of: sub-par insulation properties of a collector tube element. The latter condition may be ascertained by physical hand contact with the glass cover tube and a sense of $i$ ts being above ambient temperature; a lack of frost covering on the glass surface where most other tube covers are frosted; or by sophisticated techniques such as the use of infra red radiation detectors.

All of the collector elements required for the removal and replacement of a collector tube are easily accessible from above the plane of the collector. The system's designer/installer must ensure that suitable space is available for the mounting of a temporary support which can accommodate a. workman for the removal and replacement activity. It is recommended that any collector tube replacement be accomplished in the early morning or late afternoon hours. If only a minor replacement effort (perhaps $10 \%$ of the tubes in a module or less) is required, no problem is introduced by collector tube change at any time of the day. Two precautions should be observed. First, the center air distributor tube could be very hot and could burn the skin if touched 
shortly after removal of the collector tube. Second, if the control thermocouples are in the annulus of the collector tube element being removed, an overtemperature condition could develop after the collector tube is replaced and prior to the time system activation is attempted. Proper control system functioning would prevent system start-up.

6.1.2 Access for system monitoring.

Thermocouples (two-copper-constanton, Type T) are provided to indicate the temperature of the air in the annulus of a collector tube element. These couples are intended for use in the control of the solar energy system. The collector inlet and exit air temperatures and air mass flow measurements are required to monitor the collector thermal performance. It is recommended that six element thermopiles be mounted in the transition ducting leading to and from the collector manifold if individual collector module monitoring is desired. If monitoring of the performance of a collector array is desired, suitable temperature and air flow sensing elements will have to be located in cross appropriate cross sections of the system main air ducting.

\subsection{Installation, Operation and Maintenance Manual.}

\subsubsection{Installation instructions.}

A section of the manual deals with the installation of a Model SEC-601 air collector subsystem. No special provisions are provided for interconnections between modules. The interconnection between collector modules is to be proyided as a part of the dwelling/site installation. 
6.2.2 Maintenance and operation instructions.

Sections of the manual deal with the operating and the maintenance instructions for the collector subsystem.

\subsubsection{Maintenance plan.}

No routine maintenance plan has been developed for the Model SEC-601 collector. No component or subassembly has been designed or selected on the basis of limited life short of the design life (target, 20 years) of the collector subsystem.

\subsubsection{Replacement parts.}

No special tools or, test equipment are required for service, repair or replacement of parts or components of the Model SEC-601 collector. Service, repair or replacement parts required by unforeseen in service conditions may be ordered from the collector manufacturer: attention, Field Service Engineering, Solar Energy Products Group, 1020 N. Westwood, Toledo, Ohio, 43666, (telephone (419) 247-9705).

\subsection{Repair and Service Fersonncl.}

6.3.1 and 6.3.2 Servicing of $H, H C$ and HIN Systems.

A review of the drawings, spectficalions, mainterance instructions and a typical installation demonstrates that an installed Hodel SEC-601 collector can be conveniently and simply serviced by a trained HVAC service technician using the Installation, Operation and Maintenance Manual. 
Review of items 6.1,6.1.1, 6.1.2, 6.2, 6.2.1, 6.2.2, 6.2.3,

$6.2 .4,6.3,6.3 .1$ and 6.3 .2

SH\&G Certification Officer

$n$
$\vdots$
$r$
$r$
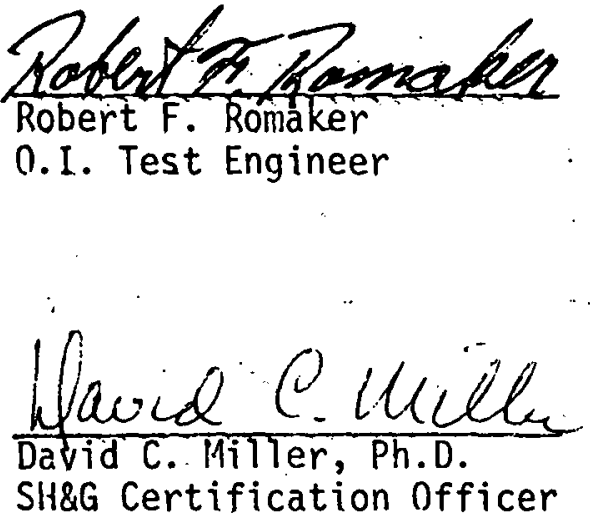



Kenneth L. Moan

P.E. (Ohio 5203)

0.1 . Approval

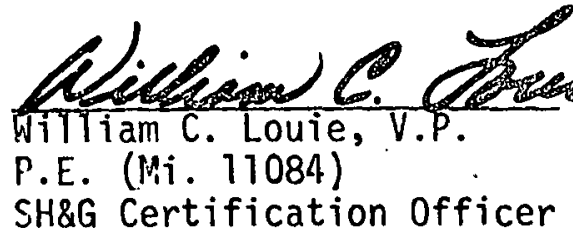

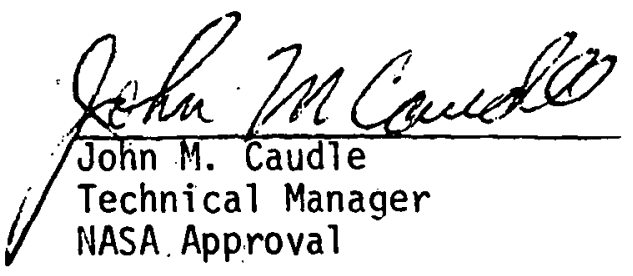

143 
11.2 Durability and Reliability of Dwelling and Site.

11.2.1 Chemical corrosion. Satisfactory completion of Criteria 5.3.3 and 5.3.4 (Chapter Five) satisfies the criterion of this section - 11.2.1.

11.2.2 Heat and moisture.

Physical and visual inspection of a Model SEC-601 collector subsystem installed and operating demonstrates that no heat or moisture build up can or will occur by a collector installation.

11.3 Durability and reliability of connections.

11.3.1 Satisfactory completion of Criterion 5.3.2 of Chapter Five constitutes satisfactory compliance with this criterion - 11.3.1.

Review of items $11.2,11.2 .1,11.2 .2,11.3$ and 11.3 .1 successfully completed.
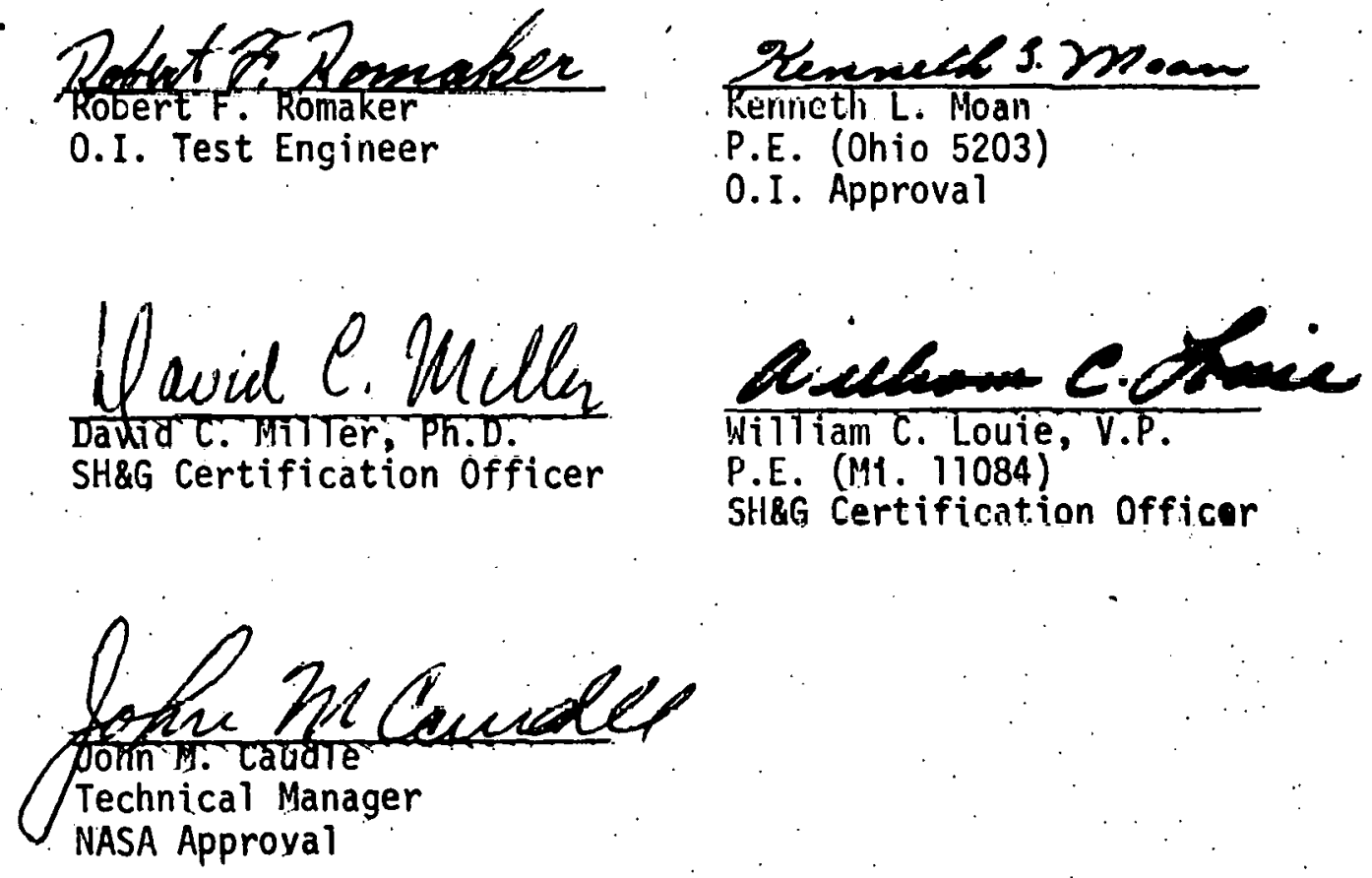